\title{
Odnos ženskog, ženstvenog i tekstualnog u opusu Oriane Fallaci
}

\section{Kovačević, Astrid}

\section{Doctoral thesis / Disertacija}

2021

Degree Grantor / Ustanova koja je dodijelila akademski / stručni stupanj: University of Zagreb, Faculty of Humanities and Social Sciences / Sveučilište u Zagrebu, Filozofski fakultet

https://doi.org/10.17234/diss.2021.8125

Permanent link / Trajna poveznica: https://urn.nsk.hr/urn:nbn:hr:131:235213

Rights / Prava: In copyright/Zaštićeno autorskim pravom.

Download date / Datum preuzimanja: 2023-04-26

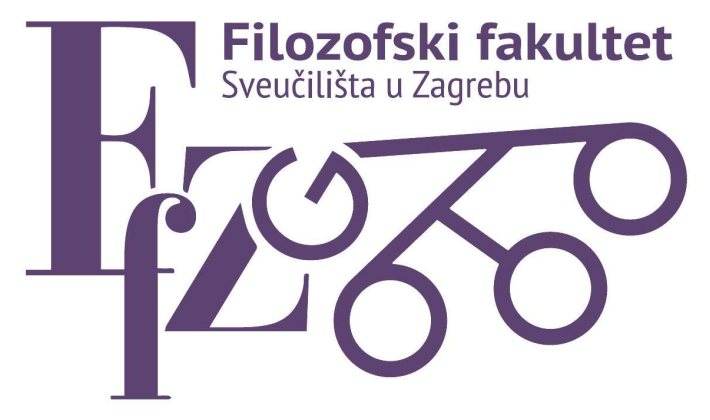

Repository / Repozitorij:

ODRAZ - open repository of the University of Zagreb Faculty of Humanities and Social Sciences
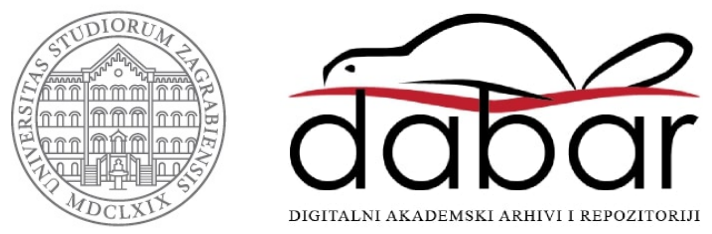


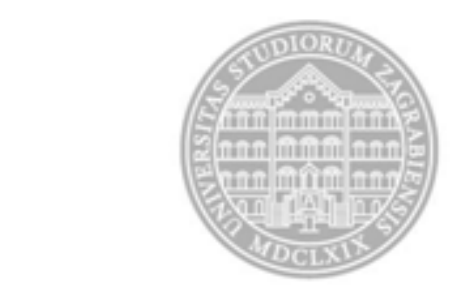

Sveučilište u Zagrebu

FILOZOFSKI FAKULTET

Astrid Kovačević

\section{ODNOS ŽENSKOG, ŽENSTVENOG I \\ TEKSTUALNOG U OPUSU ORIANE FALLACI}

DOKTORSKI RAD

Zagreb, 2021. 


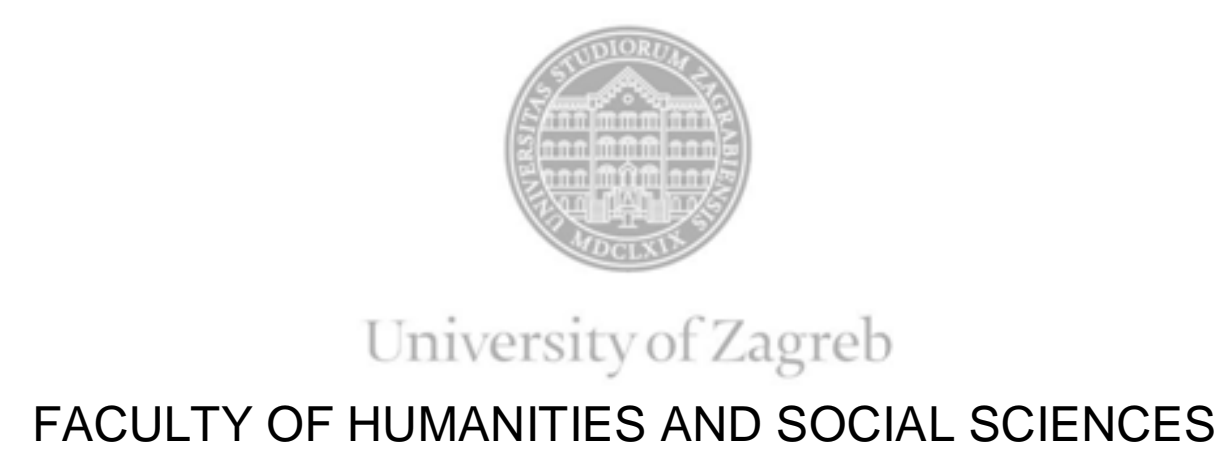

Astrid Kovačević

\title{
THE RELATIONSHIP BETWEEN THE FEMALE, FEMININE AND TEXTUAL IN THE WORK OF ORIANA FALLACI
}

\author{
DOCTORAL THESIS
}

Zagreb, 2021. 


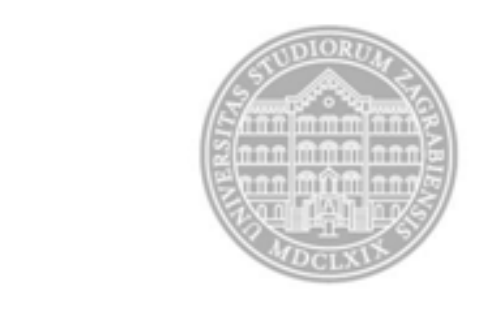

Sveučilište u Zagrebu

FILOZOFSKI FAKULTET

Astrid Kovačević

\title{
ODNOS ŽENSKOG, ŽENSTVENOG I TEKSTUALNOG U OPUSU ORIANE FALLACI
}

\author{
DOKTORSKI RAD
}

Mentor:

Doc. Dr.sc. Maša Grdešić

Zagreb, 2021. 


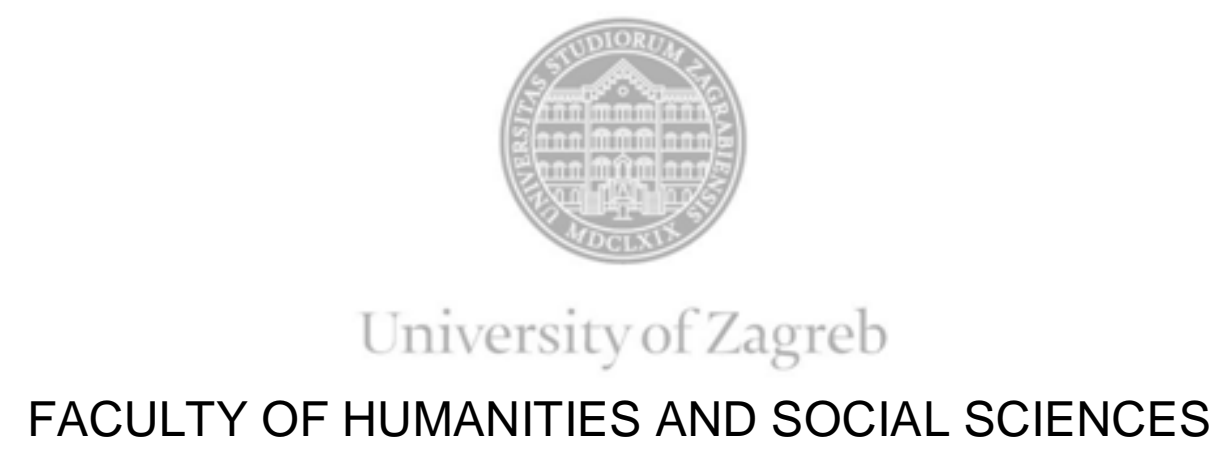

Astrid Kovačević

\title{
THE RELATIONSHIP BETWEEN THE FEMALE, FEMININE AND TEXTUAL IN THE WORK OF ORIANA FALLACI
}

\author{
DOCTORAL THESIS \\ Mentor: \\ Doc. Dr.sc. Maša Grdešić
}

Zagreb, 2021. 


\section{SADRŽAJ}

Sažetak I.

Sažetak II. $\quad 7$

$\begin{array}{ll}\text { Summary II. } & 15\end{array}$

$\begin{array}{ll}\text { Uvod } & 23\end{array}$

\section{DIO: TEORIJSKE REFLEKSIJE SPOLNO, RODNO, JEZIČNO}

\section{O ŽENSKOM SUBJEKTU}

I. I. ŽENA KAO "DRUGO"

I. I. I. Frojdovska psihoanaliza $\quad 30$

I. I. II. Postfrojdovska psihoanaliza 38

I. I. III. Egzistencijalistički feminizam $\quad 42$

I. I. IV. Analitička psihologija 47

I. II. S FEMINIZMA NA NEOFEMINIZAM

I. II. I. Kontrakulturni preokret $\quad 54$

I. II. II. Women'sLib $\quad 58$

I. II. III. Žensko, ženstveno, tekstualno 64

\section{O ŽENSKOM IDENTITETU}

II. I. SEKSUALIZIRANO ŽENSKO PISMO

$\begin{array}{ll}\text { II. I. I. Luce Irigaray } & 71\end{array}$

II. I. II. Hélène Cixous $\quad 76$

II. I. III. Julia Kristeva $\quad 83$

$\begin{array}{ll}\text { II. I. IV. Adriana Cavarero } & 88\end{array}$

II. II. (NADO)GRADNJA IDENTITETA 99

II. II. I. Identitet kao metafizički konstrukt 99

$\begin{array}{ll}\text { II. II. II. Nomadski subjekt } & 101\end{array}$

$\begin{array}{ll}\text { II. II. III. Teorija roda } & 104\end{array}$ 


\section{DIO: ORIANA FALLACI ANATOMIJA ŽENSKOG PISMA}

\section{SEKSUALNO I TEKSTUALNO}

I. I. TEKST I KONTEKST 113

I. I. I. Antiedipski bricolage 113

I. I. II. Fallaci o/u ženskom i ženstvenom 117

I. I. III. Retorika slobode 120

I. II. TIJELO I TEKST 128

$\begin{array}{lr}\text { I. II. I. Onkraj označenog } & 128\end{array}$

I. II. II. Biseksualna tekstualnost 134

I. II. III. Placentalna retorika 144

II. KOLONIZACIJA ŽENSKOG

\section{SUBJEKTA}

II. I. OTVORENA TEKSTUALNOST 157

II. I. I. Glas Drugog 157

II. I. II. Fallacin Pendulum 164

II. II. NOMADSKA ESTETIKA 169

$\begin{array}{lr}\text { II. II. I. Autor in fabula } & 169\end{array}$

$\begin{array}{ll}\text { II. II. II. (Auto)biografska subverzija } & 179\end{array}$

$\begin{array}{ll}\text { II. II. III. Lingvistička deteritorijalizacija } & 190\end{array}$

$\begin{array}{ll}\text { Zaključak } & 198\end{array}$

$\begin{array}{ll}\text { Bibliografija } & 203\end{array}$ 


\section{Sažetak I.}

$\mathrm{U}$ disertaciji se razmatra prisutnost specifičnoga ženskog govora (le parler femme) i ženskog pisma (l'écriture féminine) u opusu Oriane Fallaci te njihov odnos s autoricom kao stvarnom, izvantekstualnom osobom. Polazi se od spoznaja poststrukturalističke teorije teksta te psihoanalitičkog feminizma, koje se proširuju rezultatima istraživanja u području kognitivne lingvistike, pragmalingvistike i teorije roda. Pomnim čitanjem odabranih naslova iz Fallacinog opusa te lingvističkom analizom odabranih ulomaka opisat će se odnos ženskog, Ženstvenog i tekstualnog. Na temelju kritičkoga čitanja teorijske literature i rezultata analize polaznih i ciljnih tekstova revidirat će se model ženskog pisma, koji će uvažiti i rezultate istraživanja u području lingvistike i teorije teksta.

Interdisciplinarnost teme zahtijeva osmišljanje i razvijanje prikladne metodologije, kombinirajući istraživačke metode i postupke svojstvene disciplinama i(li) pristupima iz kojih proizlazi tema rada. Naime, pitanje ženskosti i ženstvenosti utemeljeno je u psihoanalitičkoj teoriji te teoriji roda, uspostavljajući poveznice s teorijom teksta i lingvistikom dolazi se do uočavanja osobitih odnosa između roda, spola i teksta. Usvojene spoznaje i metode primjenjuju se u lingvističkoj analizi važnih dijelova odabranih tekstova deskriptivnom te analitičko-poredbenom metodom. Metodom indukcije, sinteze i apstrakcije, na temelju analiziranih primjera, o razmatranome konceptu i navedenim odnosima, ženskog, ženstvenog i tekstualnog, oblikuje se zaključak o prisutnosti seksualiziranog pisma u opusu Oriane Fallaci.

Očekivani je znanstveni doprinos ovoga rada u boljem razumijevanju odnosa između roda, spola i jezika, te produbljivanju suvremenih istraživanja o ženskom glasu i pismu. Rezultati predstavljaju doprinos dosadašnjim istraživanjima o Oriani Fallaci, s naglaskom na specifičnost ženskog izraza, te nude nov interdisciplinaran teorijski model za razumijevanje njezinih tekstova.

Ključne riječi: potiskivanje, sublimacija, psihički registri, edipsko, prededipsko, simboličko, imaginarno, nagonska teorija, spolnost u jeziku, ženskost, ženstvenost, psihoanalitički feminizam, egzistencijalistički feminizam, teorija roda, poststrukturalizam, francuski feminizam, nomadsko pismo, antiedipska estetika, falokracija, dekonstrukcija subjekta, identitet, podosobnost, žensko pismo, ženski govor, kontraseksualnost, biseksualna tekstualnost, placentalna retorika, Oriana Fallaci. 


\section{Sažetak II.}

U ovoj kompleksnoj interdisciplinarnoj doktorskoj disertaciji, razmatraju se recipročni odnosi spola, roda i jezika, utjecaj ženskog spola i roda na jezik, karakteristike ženskog i ženstvenog govora (le parler femme), ženskog i ženstvenog pisma (l'écriture féminine), te njihova prisutnost u djelima Oriane Fallaci.

Proučavanje posebnih karakteristika ženskog pisma nametnulo se kao relevantna tema u drugoj polovici prošlog stoljeća, ponajviše pod utjecajem frojdovske psihoanalize, kojom su prvi put određene osnovne karakteristike ženske osobnosti i karaktera (Freud, 2006).

Žensko i ženstveno Freud veže uz elemente edipske i prededipske paradigme (p. 412) te uz strukturiranje, odnosno manjkavu kompaktnost nadstrukture psihičkog aparata (p. 415). Na takvu, djelomično prirodom određenu, pasivnu ženskost i ženstvenost društvo i socijalni poredak, ističe Freud, nadograđuju niz konvencija i normi (p. 405).

Jacques Lacan potvrđuje Freudove teze o prirodi ženskosti, te ženskost i ženstvenost smješta u prostor izvan i onkraj jezika, u prostor koji izmiče simboličkom, odnosno označiteljskom, identificirajući ih kao „nefalične“ te stoga i „nepotpune“ (Lacan, 2017). Inzistirajući na prevlasti falusnih svojstava, Lacan ženu ostavlja obilježenu kao „prostor seksualnog prodora“" (Lacan 1983, p. 255-257).

Frojdovski koncept edipacije postfrojdovska psihoanaliza nastoji pomaknuti unatrag, stavljajući naglasak na prededipsko razdoblje, kao ključno razdoblje spolnog sazrijevanja i formiranja identiteta, čime ženska i ženstvena marginalizacija bivaju poništene (Laplanche i Pontalis 2010, p. 433-434).

Konačni odmak od androcentričnih teorija spolnosti vidljiv je u Jungovim tekstovima koji žensku psihičku strukturu, odnosno osobnost, vidi različitom, dominantno intuitivnom, osjetilnom i emotivnom (Jung 1977, p. 225-226) s prisutnom urođenom slikom drugog spola, tzv. animusom (p. 206-208), što je kasnije poslužilo kao polazišna točka u definiranju pojmova poput podosobnosti, kontraseksualnosti, biseksualnosti unutar tekstualnog prostora (Young-Eisendrath, 2004). 
Beauvoir odbacuje psihoanalitička tumačenja ženskog i ženstvenog, tvrdeći kako u njima spolnost koegzistira s egzistencijom (Beauvoir, 2016, p. 58) te ističe kako ženskom biću ženskost i ženstvenost nisu urođene (p. 287). Također, napominje i kako žensku umjetničku kreativnost i produkciju uvjetuju iskustva, ženin marginaliziran društveni položaj te osjećaj psihološke i emocionalne sputanosti, pa postavlja pitanje ,razlikuje li ženska kreativnost rod od spola?““(Beauvoir, 2001).

Ellmann (1968) napominje kako je ženstvenost isključivo društveno konstruiran termin, koji ni na koji način ne opisuje stvarnu prirodu, a ujedno ga je i nemoguće tekstualno fiksirati jer je u kontinuiranom procesu jezične dekonstrukcije. Ellmann zaključuje kako je iz tog razloga nemoguće odrediti ženski tekst ili žensku rečenicu (p. 172).

Gilbert i Gubar (1979), razmatrajući prirodu i dinamiku ženske umjetničke kreativnosti, predlažu nov teorijski model za razumijevanje ženske tekstualne strategije, ističući kako se ona bitno razlikuje od one muških autora, poglavito u vidu sintaktičkih konstrukcija i dekonstrukcija, sintagmatske i paradigmatske fragmentiranosti te sveprisutnog autoričinog glasa. Također, mišljenja su da svaki ženski tekst skriva stvarnu ženu, a ukoliko tekst nije sama autorica, onda je barem produžetak njezinih podsvjesnih mehanizama (p. 85-90).

Kolodny (1975) problematici proučavanja ženske tekstualne strategije kao odvojene kategorije pristupa nešto opreznije, naglašavajući kako isticanjem osobitosti ženskog pisma nužno određujemo kvalitativni udio rodnog i spolnog (p. 76-78), dok Showalter (1979) ističe važnost sustavnog izvantekstualnog ginocentričnog pristupa ženskim tekstovima, odbacujući formalno teorijsko istraživanje teksta kao prostora znakova i označivanja, primarno se priklanjajući onim znanstvenim područjima koja su „u najvećoj mjeri pridonijela razumijevanju ženske supkulture: antropologiji, psihoanalizi, lingvistici te kulturalnim teorijama“"(Showalter, 1981).

Nadalje, Jehlen (1981) napominje kako su ženski tekstovi kodirane poruke autoričina glasa. Irigaray (1974) smatra kako zapadnjački filozofski diskurs ženu promatra kao „zrcalni odraz muškog subjekta“, a ženstvenost kao „negativ muževne refleksije“ (p. 20). Žensko i ženstveno postaju tako sekundarne tvorevine čija su svojstva podređena primarno prolaskom kroz imaginarij muškog. Između ženske morfologije i ženske psihologije Irigaray vidi značajnu analogiju. Obje su pluralne, inkluzivne i fluidne te daju prednost taktilnom (Irigaray 1977, p. 
24-25), a ženski govor (le parler femme) karakterizira intimna povezanost s vlastitim tijelom te opiranje konačnim fiksacijama i značenjima (p. 76).

Cixous (1977) razmatra žensko i ženstveno unutar tekstualnog, tvrdeći kako je ženstven onaj tekst koji ,radi na razlici“ (p. 480), na rušenju sustava binarnih opreka, a žensko je pismo prostor užitka (jouissance) te prostor razmjene s drugim (Autre). Ono je uvijek libidan čin koji označava „artikulaciju žudnje u jeziku“ (Moi 2007, p. 176), njime seksualno prodire u tekstualno, stapajući se i postajući jedno. Cixous ističe kako je žensko pisanje (l'écriture féminine) u naravi govorni čin te se ženstvenost u pisanju može raspoznati kao davanje prednosti glasu, jer žena koja govori „fizički materijalizira ono o čemu razmišlja, označava to svojim tijelom“(Cixous 1975a, p. 251; 1975b, p. 170).

S druge strane, Kristeva (1974) odbija definirati žensko i ženstveno, smatrajući kako takva terminologija zatvara razlikovno polje značenja i determinira navedene karakteristike kao nepromjenjive ontološke biti. Sumnjajući u mogućnost definiranja ženskog identiteta (1981, p. 36) sumnja i u mogućnost definiranja ženskog pisanja. Negirajući bilo kakav oblik biologizma i esencijalizma, odbacujući metafizičku dihotomiju ženstvenog i muževnog, Kristeva ženskost $\mathrm{i}$ ženstvenost razmatra isključivo kao marginalne pozicije u odnosu na centralizirane strukture moći.

Cavarero (2002) odbacuje dosad navedeno te tvrdi kako jezik žene ne postoji, kako žene stvarnost interpretiraju jezikom Oca, prevodeći ga i usvajajući ga poput stranog jezika, vjerujući da im pripada. Prilikom tog usvajanja, zaključuje, nastaju pukotine i praznine, iz kojih nastaju muk i nerazumijevanje.

Istraživanje se nastavlja kritičkim razmatranjem pojmova ženski identitet, nomadski subjekt te ženski identitet kao metafizički konstrukt, a potvrđuje se komparativnom analizom djela Braidotti (2002) koja, na temelju filozofskih pretpostavki Deleuzea i Guattarija o nomadizmu, iznosi teoriju o ženskom identitetu kao fluktuirajućem pojmu, Butler (1990), koja razmatra Foucaultove teze o tjelesnosti i identitetu, potvrđujući Kristevine navode o nemogućnosti definiranja spolnog i rodnog identiteta, te Battersby (1998), koja zapadnjački metafizički koncept ženskog identiteta u potpunosti izokreće, tvrdeći kako ženskost i ženstvenost nisu trajni i konačni oblici. 
Naposljetku, cjelokupno istraživanje usmjerava se na analizu djela Oriane Fallaci, s osobitim naglaskom na autoričin glas, gotovo neodvojiv od Fallaci kao izvantekstualne, stvarne osobe.

Fallacini raniji tekstovi, Il sesso inutile (1961) te Penelope alla guerra (1962), ukazuju na autoričinu negaciju binarnog i bipolarnog strukturalističkog falogokratičnog vrijednosnog sustava (Derrida, 2007), odnosno na afirmaciju poststrukturalističkog koncepta heterogene različitosti, différance (Cixous 1977a, p. 480), koji pisanoj riječi dodjeljuje fluktuacijsko, pokretljivo, svojstvo, oslobađajući je od mogućnosti zatvaranja i konačne fiksacije značenja. Ostvarujući vremensku i prostornu otvorenost teksta, otvoren sustav označivanja, signifiance (Kristeva 1980, p. 27), autorica ulazi u prostor neprekidnog oblikovanja i heterogene destruktivne uzročnosti (p. 27), poništavajući arhaično shvaćanje jezika kao stabilnog, monolitnog, kompaktnog i cjelovitog sustava znakova.

Izlazeći iz standardnog saussureovskog koncepta jezika, određujući ženski subjektni položaj, odnosno njezin objektni izbor, oba u uskoj vezi s fiziološkim i sociopsihološkim statusom žene (Fallaci 1961, p. 254), kao marginalan i subverzivan (p. 9) u odnosu na centralizirane i institucionalizirane patrijarhalne strukture moći, pretačući spolnu i rodnu ambivalentnost, odnosno subverziju tijela i identiteta (Fallaci, 1962), u heterogeni prostor lingvističke semioze, Fallaci temeljito dekonstruira osnovne instalacije simboličkog poretka, nesvjesno potvrđujući svoje žensko i ženstveno pismo kao marginalno, heterogeno i subverzivno (Kristeva 1977b, p. 3-8).

Fallacina biseksualna tekstualna strategija (Fallaci, 1962), koja ukazuje na povezanost autoričinog $J a$ s obje erotsko-emotivne polovice nesvjesnog (Cixous, 1975b), rastvarajući i rastačući zapadnjačku paradigmu faličke monoseksualnosti i edipskog konteksta, tekstualan prostor označava kao prostor libidne slobode i potpunog opuštanja libidnih poriva (Bonfante 1975, p. 72), mjesta izraženoga afiniteta prema pisanju kao karnalnoj materijalizaciji glasa (Cixous, 1975c).

Odustajanje od krutih morfosintaktičkih zakona i povratak pisanju kao glasu, govornom činu koji materijalizira seksualnost, vodi Fallacinu tekstualnost u smjeru tjelesnog, ženskog i ženstvenog. Vlastitim glasom, konačnoj inkarnaciji žudnje unutar jezičnog (Lacan, 1992), koja proizlazi iz najnedostupnijih slojeva psihe, autorica ovladava i nadilazi prostor simboličkog, vraćajući pisanje tijelu, u prostor onkraj označenog. 
Fallacino fluidno i viskozno pismo (Gatt-Rutter 1996, p. 72) nalazi se u prostoru izvan Zakona. Njegova pokretljiva, nestlačiva, mnogostruka i varijabilna svojstva, omogućuju uspostavu procesa beskonačne lingvističke semioze. Kvalitativna i kvantitativna distribucija prozodemskih i interpunkcijskih elemenata, kao i fonetsko-morfološke intervencije, fizičko pretvaraju u metafizičko, tjelesno u grafološko, a nekonvencionalna i protuinstitucionalna, antitradicionalistička i antipatrijarhalna, izraženo fonična i taktilna (Irigaray 1977, p. 76) retorika briše granice tjelesnog i psihološkog, stvarnosti i fikcije, teksta i konteksta.

Fallacina prededipska retorika, osobito izražena u Lettera a un bambino mai nato (1975), označava usku povezanost autoričinog materijalnog tijela (ženskosti), fizičke materijalizacije njezinog glasa (ženstvenosti), s beskonačnim imaginarnim tekstualnim prostorom (Cixous 1975c, p. 170). Analizirajući intimnu komunikaciju žene i djeteta u utrobi, odnosno autorice i njezinog nerođenog teksta (Fallaci, 1975), Gatt-Rutter (1996, p. 63) izlaže tezu o ženskom tijelu koje progovara, o tkivima koja emaniraju misli i jezik, o tzv. placentalnoj retorici s izuzetno izraženim foničkim amplitudama koje putuju biološkim tkivima i tjelesnim tekućinama. Taj imaginarni kozmički vodeni prostor heterogenog (Cixous 1975b, p. 260), kojim dominiraju zvuk, fluid i taktilno, simbol je apsolutne retoričke slobode, odsustva simboličkih autoriteta, ali i ženstvenosti, prirodne i neposredne povezanosti s vlastitom ženskošću.

Fallacino odupiranje svakom obliku edipskog totalitarizma i hegemonije, kao i odustajanje od etabliranih žanrovskih konvencija, rezultirat će atipičnim žanrovskim entitetima s izraženim psihološkim otiskom autorice (Porzio, 1965). Takvi će, formalno neodređeni, tekstovi, pratiti program tzv. antiedipske estetike (Irigaray, 1974), unutar koje predvidivost i cjelovitost, jedinstvo i totalitet, red i sustavnost, ustupljuju svoja mjesta spontanosti i fragmentiranosti, varijabilnosti i mnogostrukosti, preklapanju i preplitanju. Aricò (1998, p. 167) naglašava kako je u Fallacinom slučaju došlo do formalnog kreativnog nereda, do gotovo potpune fuzije stvarnosti i fikcije, nejasnog prijelaza pisane i izgovorene riječi, do preklapanja ekstradijegetskih i intradijegetskih silnica, odnosno do uspostave čvrste semantičko-sintaktičke veze između autora i pripovjedača (Fallaci 1990, p. 596).

Takva neuniformirana tekstualna struktura rezultat je nepostojanja univerzalnog i sveznajućeg, superiornog i nadređenog, autorskog sebstva izvan granica tekstualnog. Fallacina, ženska i ženstvena, lingvistička kreativnost suprotstavlja se faličkom hijerarhijskom 
sustavu, koji podrazumijeva unaprijed izgrađen autorski identitet. Priklanjajući se poststrukturalističkoj metodologiji, koja autora i pripovjedača čini rezultatima retoričkih strategija, odnosno čini tekst nadređenim i povlaštenim pojmom (Cavarero, 1997), te odbacujući kanonski metodološki pristup (Aricò 1998, p. 171-173), izgovarajući, no istodobno i osluškujući tekst (Derrida 1988, p. 13), autorica subjekt pretvara u objekt, tekst u „verbalnu projekciju vlastitog sebstva““ (Aricò 1986, p. 587).

Fallacina autorska i pripovjedačka subverzija, najočitija u romanima Niente e così sia (1969) te Un uomo (1979), tekstualno pretvara u vokalno (Spinazzola, 1979), biografsko u autobiografsko (Rosa 1982, p. 77-80), stvarnost u fikciju (Aricò 1998, p. 167). Na tragu francuskog poststrukturalizma, Fallaci odustaje od afirmacije autorskog subjekta kao omnipotentnog ekstradijegetskog identiteta, distanciranog od vlastitog teksta. Prema njezinom mišljenju (Aricò 1998, p. 172), autorski je subjekt retorički konstrukt, uspostavljen hermeneutičkim procesima, trenucima u kojima subjekt teksta i subjekt čitanja zamjenjuju svoja mjesta.

Odustajanje od unaprijed izgrađene autorske osobnosti ukazuje na proces pisanja kao na proces rekonstrukcije vlastitog bića (Gusdorf 1991, p. 10). Putem pisanja, umetanja krhotina i fragmenata jezične stvarnosti, omogućava se (re)konstrukcija autorskog subjekta i njegovo/njezino pozicioniranje u odnosu na stvarnost koju opisuje (Cavarero, 1997; Battersby, 1989). Ovakve diskurzivne metode, prema mišljenju Cavarero (1997, p. 100-101), odraz su utjecaja ženskog i ženstvenog, a rezultirat će beskonačnim procesom lingvističke semioze. Fallacini tekstovi, nabijeni snažnim ženstvenim „,vokalnim imprintingom “ (Milani 1971, p. 30), postaju tako zrcalni prostor unutar kojeg se autoričino sebstvo mise en abîme efektom (Fallaci 1990, p. 157) reflektira i umnožava, prostor performativnih lingvističkih strategija (Finci 2011, p. 119).

Kontrakulturna revolucija i pokret za seksualno oslobođenje 60 -ih i 70-ih godina, donijeli su promjene na polju jezika, medijske i intrapersonalne komunikacije, te novinarskog sektora. Razvijaju se diskurzivne metode koje dotadašnje rigidne i konvencionalne formalne kriterije zamjenjuju kontekstualnim i izvantekstualnim metodama analize. Tekst više nije zatvoren prostor skupa znakova i označivanja (Showalter, 1979), već otvoren prostor interpretativne kooperativnosti, prostor u kojem autorska iskustvena saznanja, subjektivna perspektiva i intelektualna pristranost dolaze do izražaja. 
Subjektivizam, polimorfnost i lingvistička subverzija novih novinarskih oblika, poput New Journalisma, osobito su privukli Orianu Fallaci, poglavito u godinama kada su njezin interes za liberalni socijalizam i oslobođenje žene bili u punoj snazi (De Stefano 2015, pp. 179; 188189). Žudnja za oslobođenjem od patrijarhalne falocentrične političke opresije u tadašnjim se Fallacinim najuspješnijim tekstovima, sakupljenima i objavljenima u četiri opsežne zbirke pod nazivom Gli antipatici (1963), Se il sole muore (1965), Quel giorno sulla luna (1970) te Intervista con la storia (1974), zrcali i na onoj formalnoj, lingvističkoj, razini.

Njezino antiedipsko, subverzivno i subjektivizirano pismo, marginalno u odnosu na etablirane jezične strukture moći, govori o svojevrsnom lingvističkom disidentstvu (Kristeva 1977b, p. 3-8), kojim autorica ocrtava vlastitu marginalnu subjektnu poziciju. Odustajanjem od formalnog kanona, priklanjanjem analitičkim metodama i metodama kritičkog promišljanja, kao i urezivanjem osobnog političkog i psihološkog otiska, autorica portretira i projektira svoj, ženski i ženstven, glas. Uspješnost ovih Fallacinih tekstova David Sanford (1975) pripisuje autoričinoj spoznaji o komparativnim prednostima vlastitog spola, poglavito intuiciji i empatiji (Jung, 1971), koji joj omogućuju izuzetno minuciozan i jasno usmjeren proces psiholingvističke obdukcije, surgical journalism (Sanford 1975, p. 102), penetraciju i sekciju misli i jezika.

Raskidanjem ugovora s falogokratičnim lingvističkim autoritetima, odustajanjem od normi, binarne i bipolarne konceptualne hijerarhijske organizacije jezičnih i kulturnih simbola, autorica jasno uspostavlja veze s nomadskom estetikom (Braidotti, 2002), jednom od postmodernističkih interpretacija antropoloških, kulturnih i jezičnih fenomena u kojoj tradicija i teritorijalna stabilnost ustupljuju mjesto kulturnoj tranziciji i lingvističkoj deteritorijalizaciji (Deleuze i Guattari, 1986).

Fallacino nomadsko pismo, određeno prvenstveno njezinom tranzicijskom i fluktuirajućom nomadskom subjektnom pozicijom (Braidotti 2002, p. 13), antiedipski je odgovor usmjeren na statični i stabilni ,,autoritativni režim tiranskih očeva“ (p. 37). Njime autorica pruža otpor simboličkom jezičnom kapitalu, patrijarhalnim dogmama i centraliziranim zapadnjačkim institucijama sustava. Linearnom destrukcijom falogokratičnih (Derrida 2007, p. 298) hijerarhijskih sustava binarnih opreka, vraćajući se u položaj kulturnog i jezičnog relativizma (Said, 1978), odupire se i oslobađa od saussureovskog koncepta transcendentalnog označenog, povlaštenog i zatvorenog, jezičnog sustava (Derrida 2007, p. 299). 
Fallacin, ženski i ženstven, nomadski stil, usmjeren na demistifikaciju i dekonstrukciju hijerarhijski nadređenog sustava standardnog jezika i zapadnjačkih političkih enklava, stil je otvorenog, inter i trans disciplinarnog, lingvističkog bricolagea. Umetanjem i premještanjem pojedinih koncepata, jezičnih varijanti i registara, sociolekata i dijalekata, simbolički prostor Zakona, kojim dominira spolni i jezični puritanizam (Braidotti 2002, p. 29), autorica zamjenjuje imaginarnim prostorom lingvističke demokracije, prostorom unutar kojeg različiti lingvistički supstrati, heterogene linije jezične tranzicije i transgresije pomiču rasne, klasne, etničke, spolne i rodne granice (Fallaci, 1990), dovodeći u pitanje pojam identitet.

Afinitet prema egzotičnim nomadskim prostorima na međi heterogenih kultura i lingvističkih supstrata, poput beirutske „ničije zemlje“ (Lyotard 1997, p. 116) opisane u ratnom triptihu Insciallah (1990), prati autoričin afinitet prema procesu lingvističke deteritorijalizacije (Braidotti 2002, p. 36-37), procesu jezične, prostorne i vremenske dislokacije, kojim se, najčešće uz pomoć aktivnih i nesvršenih glagolskih vremena, poput imperfekta i prezent perfekta, te translingvalnih i transkulturalnih transpozicija (Fallaci 1990, pp. $22 ; 30 ; 33 ; 35 ; 58 ; 68-69 ; 74)$, nadilazi simboličko polje jezičnih zakona i ulazi u imaginaran prostor umnožive heterogene različitosti te vremenske i prostorne otvorenosti semantičkih polja jezika (Derrida 2007, p. 298-299).

Fallacina visoko kritička svijest i pogled kroz sadašnjost odlučno se suprotstavlja kultu sjećanja, divinizacije i asimilacije (Foucault, 1994), kao i svakom obliku jezičnog totalitarizma, dominacije ili političkog nasilja. 


\section{Summary II.}

This complex interdisciplinary doctoral dissertation examines the reciprocal relationships between sex, gender and language, the influence of female sex and gender on language and the particular characteristics of female and feminine speech (le parler femme), female and feminine writing (l'écriture féminine), as well as their presence in the work of Oriana Fallaci.

Theoretical investigation of the specific characteristics of female writing began in the second half of the previous century, based on the influence of Freudian psychoanalysis, which helped to define, for the first time, some basic characteristics of female personality and character (Freud, 2006).

Freud relates the female and the feminine to elements of the Oedipal and pre-Oedipal paradigm (p. 412), as well as to the structuring, i.e. the lacking compactness of the psychic Super-structure (p. 415). On this, partly by nature determined, passive femaleness and femininity society and social order, emphasizes Freud, superimpose additional conventions and norms (p. 405).

Jacques Lacan confirms Freud's thesis about female nature and locates the female and the feminine outside the language area, beyond the symbolic and emblematic area, identifying them as „non-phallic“, therefore ,incomplete“ (Lacan, 2017). Insisting on the supremacy of the Phallus, Lacan leaves the woman marked as „a space of sexual breakthrough“ (Lacan 1983, p. 255-257).

Post-Freudian psychoanalysis tries to move the Freudian concept of the Oedipus complex backwards, emphasizing the pre-Oedipal stage as a key stage for sexual maturing and identity formation, annulling, in that way, female and feminine marginalization (Laplanche and Pontalis 2010, p. 433-434).

The final move from androcentric theories of sexuality is notable in Jung's texts, which see the female psychological structure and personality as different, dominantly intuitive, sensorial and emotional (Jung 1977, p. 225-226) with the presence of the innate picture of the other sex, the so-called animus (p. 206-208), a theory that later helped to define terms like subpersonality, contrasexuality and bisexuality inside the textual space (Young-Eisendrath, 2004). 
Beauvoir rejects all psychoanalytic interpretations of the female and the feminine, claiming that they understand sexuality and existence as one (Beauvoir, 2016, p. 58), and emphasizes that female and feminine characteristics are not innate (p. 287). Also, she explains that women's artistic creations are influenced by experiences, as well as by women's marginalized social position, and the feeling of psychological and emotional inhibition. Therefore, she reflects upon the following question: speaking of female creativity, can we distinguish between sex and gender? (Beauvoir, 2001).

Ellmann (1968) explains how femininity is a socially constructed term, which in no way describes real nature and is also impossible to fix textually because it is in a constant process of linguistic deconstruction. Therefore, Ellmann concludes that it is impossible to define a female text or a female sentence (p. 172).

Gilbert and Gubar (1979), examining the nature and the dynamic of female artistic creativity, propose a new theoretical model in order to understand female textual strategies, pointing out the ways they differ from strategies of male authors, especially when it comes to syntactic constructions and deconstructions, syntagmatic and paradigmatic fragmentation, as well as the presence of the author's voice. Also, they claim that every text written by a woman hides the real presence of a woman, and if the text is not the author itself, then at least it is an extension of her subconscious mechanisms (p. 85-90).

Kolodny (1975) deals with the exploration of female textual strategy as a separate category, explaining, more carefully, how by emphasising the specificity of female writing, we necessarily define the qualitative portion of gender and sex (p. 76-78), while Showalter (1981) focuses on the importance of a systematic extra-textual gynocentric approach to women's texts, rejecting conventional and formal theoretical research approaches, sympathising with those researches that have, in the most obvious way, contributed to a large understanding of the female subculture, such as anthropology, psychoanalysis, linguistics, as well as cultural theories.

Further, Jehlen (1981) remarks that female texts are indeed codified messages of the author's voice. Also, Irigaray (1974) believes that Western philosophic discourse sees woman as ,a mirror reflection of the male subject“ and femininity as ,a negative of the masculine reflection“" (p. 20). In that way, the female and the feminine become secondary products, always influenced primarily by passing through the male imagination. Irigaray sees a 
significant analogy between female morphology and female psychology. Both are plural, inclusive and fluid, always privileging contiguity (Irigaray 1977, p. 24-25), nevertheless, womanspeak (le parler femme) is characterized by a strong intimate connection to the woman's own body, as well as the resistance to denotability and the final meaning (p. 76).

Cixous (1977) reflects on the female and the feminine inside the textual, claiming that a feminine text „works on différance“ (p. 480), on breaking up the binary opposition system. Also, female writing would be a pleasure area (jouissance), an area of continuous exchange with the other (Autre), a libidinous act that denotes ,the articulation of desire in language“ (Moi 2007, p. 176), through it the sexual penetrates the textual, merging together and becoming one. Cixous emphasizes that female writing (l'écriture féminine) is indeed a speech act, so femininity in writing can actually be discovered as privileging the speaking voice, because the woman who speaks ,physically materializes her thoughts“, designates them with her own body (Cixous 1975a, p. 251; 1975b, p. 170).

On the other hand, Kristeva (1974) refuses to define the female and the feminine, arguing that such a terminology closes up the varying area of meaning and determines the mentioned characteristics as unchangeable ontological essences. Questioning the possibility of defining female identity (Kristeva 1981, p. 36), she also questions the possibility of defining female writing. Denying every form of biologism and essentialism, she rejects the metaphysic dichotomy of the feminine and the masculine, considering the female and the feminine only as marginalized positions in opposition to centralized structures of power.

Cavarero (2002) rejects almost everything that was written until now, claiming that a particular female language does not exist, because women always interpret reality through the language of the Father, translating and learning it, truly believing that it belongs to them. During this appropriation process, she concludes, some cracks and gaps are developed, as well as silence and misunderstanding.

The research continues with a critical commentary of the terms female identity, nomadic subject and female identity as a metaphysic construct, also confirmed by comparative analysis of Braidotti's (2002) work, mostly based on Deleuze and Guattari's philosophic research on nomadism, which offers a theory of female identity as a floating term, Butler's work (1990), which examines Foucault's thesis on corporality and identity, and Battersby's work (1998), 
which completely twists the Western metaphysical concept of female identity around, claiming how female and feminine are not permanent and final forms.

Finally, this theoretical research is employed in a detailed analysis of Oriana Fallaci's work, specifically focusing on the author's voice, mostly inseparable from Fallaci herself as an extra-textual, real person.

Fallaci's earlier works, Il sesso inutile (1961) and Penelope alla guerra (1962), show the author's negation of the binary and bipolar structuralist phallogocratic system (Derrida, 2007), in other words, they demonstrate the recognition of the post-structuralist concept of heterogeneous diversity, différance (Cixous 1977a, p. 180), which gives particular fluctuating and mobile characteristics to the written word, setting it free from limitations of final closure and definitive designation. Achieving temporal and spatial openness of the text, in other words, the open system of designation, signifiance (Kristeva 1980, p. 27), the author enters the space of continuous shaping and „heterogeneous destructive causality“ (p. 27), annulling the archaic understanding of language as a stable, monolithic, compact and complete system of signs.

Leaving behind the standard Saussurean concept of language, defining the female subject position, i.e. her object choice, both closely related to woman's physiological, sociological and psychological status (Fallaci 1961, p. 254), as marginal and subversive (p. 9) in opposition to the centralized and institutionalized patriarchal structures of power, pouring out sex and gender ambivalence, i.e. the subversion of the body and identity (Fallaci, 1962), into the heterogeneous area of linguistic semiosis, Fallaci thoroughly deconstructs basic installations of the symbolic order, unconsciously confirming her female and feminine writing as marginal, heterogeneous and subversive (Kristeva 1977b, p. 3-8).

Fallaci's bisexual textual strategy (Fallaci, 1962), which points to the author's firm bond with both the erotic and the emotional half of the unconscious (Cixous, 1975b), dissolving and decanting the Western paradigm of phallic monosexuality and the Oedipal context, denotes textual space as a space of libidinal freedom and complete relaxation of libidinal impulses (Bonfante 1975, p. 72), a place of marked affinity for writing as a process of the carnal materialization of the voice (Cixous, 1975c).

Moving away from conventional morphosyntactic laws and turning back to writing as voice, a speech act that materializes sexuality, leads Fallaci's textuality in a bodily, female and 
feminine, direction. With her own voice, the ultimate incarnation of desire inside language (Lacan, 1992), which emerges from the most inaccessible layers of the psyche, the author masters and surpasses the space of the symbolic, bringing writing back to the body, to a place beyond the signified.

Fallaci's fluid and viscous writing (Gatt-Rutter 1996, p. 72) is situated in the space outside the Law. Its mobile, manifold and variable characteristics enable the constitution of the infinite process of linguistic semiosis. The qualitative and quantitative distribution of prosodemic and punctuation elements, as well as phonetical and morphological interventions, turn the physical into metaphysical, the body into text. The unconventional and informal, extremely phonic and tactile (Irigaray 1977, p. 76), rhetoric deletes the boundaries between the physical and the psychological, reality and fiction, text and context.

Fallaci's pre-Oedipal rhetoric, especially present in Lettera a un bambino mai nato (1975), denotes a firm connection between the author's material body (female) and the physical materialization of her voice (feminine) with the infinite imaginary textual space (Cixous 1975c, p. 170). Analysing the very intimate communication between a woman and the child in her womb, in other words, the author and her unborn text (Fallaci, 1975), Gatt-Rutter (1996, p. 63) posits his thesis on the female body that talks, on tissues that emanate thought and language, on the so-called placental rhetoric with pronounced phonic amplitudes that travel through biological tissues and bodily fluids. This imaginary cosmic watery space of heterogeneousness (Cixous 1975b, p. 260), dominated by sound, fluid and touch, acts as a symbol of an absolute rhetoric of freedom, a complete absence of all symbolic authorities, but also as a symbol of femininity, of the natural and direct connection with one's own femaleness.

Fallaci's refusal of all forms of Oedipal totalitarianism and hegemony, as well as moving away from already established generic conventions, will result in atypical generic entities bearing a pronounced psychological stamp of the author (Porzio, 1965). These formally undefined texts will follow the program of the so-called non-Oedipal aesthetics (Irigaray, 1974), within which predictability and completeness, integrity and totality, order and system give up their places to spontaneity and fragmentariness, variability and heterogeneousness, overlapping and interweaving. Aricò (1998, p. 167) emphasizes how in Fallaci's case this resulted in a formal creative mess, an almost complete fusion of reality and fiction, a blurred 
transition from the written to the spoken word, an overlapping of extradiegetic and intradiegetic levels, i.e. in the constitution of a firm semantic and syntactic connection between the author and the narrator (Fallaci 1990, p. 596).

This incongruous and asymmetrical textual structure is a result of the complete absence of the universal, omniscient and superior author's self existing outside the textual borders. Fallaci's female and feminine linguistic creativity opposes the phallic hierarchic system, which includes an already constructed author's identity. Inclined towards poststructuralist methodology, which sees the author and the narrator as results of rhetorical strategies, i.e. sees the text as a superior and privileged term (Cavarero, 1977), as well as rejecting the conventional methodological approach (Aricò 1998, p. 171-173), pronouncing but at the same time overhearing the text (Derrida 1988, p. 13), the author turns the subject into an object, the text into a „verbal projection of her own self“ (Aricò 1986, p. 587).

Fallaci's subversion of the author and the narrator, more obvious in novels Niente e così sia (1969) and Un uomo (1979), turns the textual into vocal (Spinazzola, 1979), biography into autobiography (Rosa 1982, p. 77-80), reality into fiction (Aricò 1998, p. 172). In line with French poststructuralism, Fallaci gives up the affirmation of the authorial subject as an omniscient extradiegetic identity, distanced from his/her own text. In her opinion (p. 172), the authorial subject is a rhetorical construct, constituted by interpretative procedures, moments in which the subject of the text and the subject of reading exchange their places.

Giving up an already constructed authorial personality reveals the process of writing as a process of reconstruction of one's own being (Gusdorf 1991, p. 10). Through writing, and injecting of pieces and fragments of linguistic reality, a (re)construction of the authorial subject is enabled, as well as his/her positioning related to the reality that he/she describes (Cavarero, 1997; Battersby, 1989). Such discursive methods, in Cavarero's opinion (1997, p. 100-101), reflect the influence of the female and the feminine, and will result in a neverending process of linguistic semiosis. Fallaci's texts, charged with a strong feminine „vocal imprinting“ (Milani 1971, p. 30), become, in this way, a mirror space in which the author's self, by a mise an abîme effect (Fallaci 1990, p. 157), reflects and multiplies, a space of performative linguistic strategies (Finci 2011, p. 119).

The countercultural revolution and the sexual liberation movement of the 1960's and 1970's brought change to language, media and the field of interpersonal communication, as well as 
the journalism sector. New unconventional discursive methods were developed and replaced old fashioned and rigid formal criteria with alternative contextual and extra-textual methods of analysis. The text is no longer a closed space of signs and designation (Showalter, 1979), but an open space of interpretative cooperation, a space where the author's experiences, his/her subjective perspective and intellectual judgement are prominent.

Subjectivity, polymorphism and linguistic subversion of new journalistic forms, such as New Journalism, especially attracted Oriana Fallaci, mostly in the years when her interest in liberal socialism and women's liberation was at the highest level (De Stefano 2015, pp. 179; 188-189). Her desire for liberation, formally and linguistically, from patriarchal phallocentric political oppression is far more obvious in her, at that time, most successful texts, gathered and published in four extensive collections: Gli antipatici (1963), Se il sole muore (1965), Quel giorno sulla luna (1970), and Intervista con la storia (1974).

Her non-Oedipal, subversive and subjective writing, marginal to established linguistic structures of power, demonstrates her linguistic dissident position (Kristeva 1977b, p. 3-8), i.e. her marginalized subject position. By rejecting the formal canon, embracing new analytical and critical methods of thinking, as well as engraving her personal political and psychological imprint, the author portrays and projects her own, female and feminine, voice. David Sanford (1975) ascribes the success of these Fallaci's texts to the author's awareness of the comparative advantages of her own sex, mainly intuition and empathy (Jung, 1971), which enable her extremely precise and clearly directed process of psycholinguistic autopsy, so-called surgical journalism (Sanford 1975, p. 102), the penetration and section of thought and language.

By breaking the contract with phallogocratic linguistic authorities, giving up norms, the binary and bipolar hierarchic organization of language and cultural symbols, the author clearly establishes connections to the so-called nomadic aesthetic (Braidotti, 2002), one of the postmodern interpretations of anthropological, cultural and linguistic phenomena in which tradition and territorial stability give way to cultural transition and linguistic deterritorialization (Deleuze and Guattari, 1986).

Fallaci's nomadic writing, first of all defined by her transitional and floating nomadic subject position (Braidotti 2002, p. 13), is a non-Oedipal answer directed to the firm and stable „authoritative régime of tyrannical fathers“ (p. 37). Through it, the author shows her 
disobedience to the symbolic order, patriarchal dogmas and to centralized Western systemic institutions. Deconstructing the phallogocratic hierarchic system of binary and bipolar oppositions (Derrida 2007, p. 298), going back to the position of cultural and linguistic relativism (Said, 1978), she opposes the Saussurean concept of the transcendental signified, the privileged and closed linguistic system (Derrida 2007, p. 299).

Fallaci's female and feminine nomadic style, aiming for the deconstruction of the superior hierarchic standard linguistic system, as well as the demystification of Western political enclaves, is an open inter and transdisciplinary linguistic bricolage. Through putting in and pouring out of different concepts, linguistic variants and registers, sociolects and dialects, the author replaces the symbolic area of the Law, dominated by sexual and linguistic puritanism (Braidotti 2002, p. 29), with an imaginary area of linguistic democracy, a space where all kinds of linguistic substrata, heterogeneous lines of linguistic transition and transgression shift racial, class, ethnical, sexual and gender boundaries (Fallaci, 1990), questioning the term identity.

Fallaci's affinity for exotic nomadic landscapes at the boundaries of heterogeneous cultures and linguistic substrata, such as Beirut's „no man's land“ (Lyotard 1997, p. 116) described in the war triptych Insciallah (1990), parallels the author's affinity for the process of linguistic deterritorialization (Braidotti 2002, p. 36-37), a process of continuous linguistic, temporal and spatial dislocation. Mostly through the use of imperfective verbs, translinguistic and transcultural transpositions (Fallaci 1990, pp. 20;30;33; 35; 58; 68-69; 74), Fallaci surpasses the symbolic field of linguistic law and enters into the imaginary space of multipliable heterogeneous diversity, temporal and spatial semantic openness (Derrida 2007, p. 298-299).

Fallaci's highly critical conscience and her perspective grounded in the present strongly oppose the cult of remembrance, divinization and assimilation (Foucault, 1994), as well as any form of linguistic totalitarianism, domination and political violence.

Key words: repression, sublimation, psychic registers, Oedipal, pre-Oedipal, symbolic, imaginary, drive theory, sexuality in language, femaleness, femininity, psychoanalytic feminism, existential feminism, gender theory, poststructuralism, French feminism, nomadic writing, anti-Oedipal aesthetics, phallocracy, deconstruction of the subject, identity, subpersonality, woman's writing, woman's speech, contrasexuality, bisexual textuality, placental rhetoric, Oriana Fallaci. 


\section{Uvod}

Disertacija je zamišljena kao doprinos boljem razumijevanju odnosa između rodnog, spolnog i jezičnog, odnosno ženskog, ženstvenog i tekstualnog, s osobitim naglaskom na manifestacije spolnog $\mathrm{i}$ rodnog $\mathrm{u}$ tekstovima Oriane Fallaci. Istraživanje započinje proučavanjem relevantne znanstveno-teorijske literature, ponajprije iz područja psihoanalitičke teorije te psihoanalitičkog feminizma, poststrukturalističke teorije teksta, kognitivne lingvistike, pragmalingvistike te interdisciplinarnih rasprava o fenomenu dekonstrukcije subjekta, identiteta te odnosima između roda, spola i glasa.

Ponajprije se identificiraju odnosi ženskog i ženstvenog, zatim ženskog i ženstvenog s tekstualnim. Definiraju se osnovne karakteristike ženske osobnosti i karaktera (Freud, 2006) te ženski položaj u odnosu na jezik (Lacan, 2017). Odmakom od androcentričnih teorija spolnosti (Jung, 1977) kreće se u reviziju pojmova ženskost i ženstvenost te analizu termina podosobnost i biseksualnost unutar tekstualnog (Young-Eisendrath, 2004). To su istodobno tematske jedinice i pojmovne kategorije koje su temeljne za psihoanalitičku feminističku teoriju, pa tako daju općenit pregled frojdovske, postfrojdovske i jungovske psihofeminističke paradigme.

Daljnja istraživanja i usporedbe iz područja psiholingvistike, psihoanalitičkog feminizma te poststrukturalističke teorije teksta dovode do svojevrsnog teorijskog obrata. Kako su pojedini Freudovi i Lacanovi tekstovi, od strane nekih feminističkih teoretičarki, često kritizirani, razmotrit će se radovi, na temu ženskosti i ženstvenosti, onih autorica radikalnog feminizma s kraja šezdesetih i početka sedamdesetih koje zahtijevaju potpunu reviziju nagonske teorije, optužujući psihoanalitičare za propagiranje jeftinog biološkog esencijalizma, ali i autorica druge polovice sedamdesetih te osamdesetih godina koje ustraju na važnosti rehabilitacije frojdovske i lacanovske psihoanalize u svrhu razumijevanja konstituiranja ženskog subjekta.

Istraživanje se nastavlja analizom onih znanstvenih djela koja nastoje predložiti jasan teorijski model za razumijevanje ženske tekstualne strategije i kreativnosti, u kojima je ženska tekstualna strategija predočena kao jedinstvena i specifična (Gilbert i Gubar, 1979), te u kojima se ističe važnost izvantekstualnoga ginocentričnog pristupa ženskom tekstu (Showalter, 1981). Također, osobit je naglasak stavljen na razmatranje onih znanstvenih tekstova u kojima se ističe povezanost ženskog tijela, glasa i pisma, u kojima se svaki tekst 
promatra kao „kodirana poruka autoričina glasa“ (Jehlen, 1981). Drugim riječima, analiziraju se utjecaj i odnos ženskosti i ženstvenosti na područje jezika i govora (Irigaray 1977, p. 2476), definira se priroda ženskog teksta, razmatra se „otisak ženskog autorskog glasa“ (Cixous, 1977) te ženska tjelesna retorika slobodnoga govornog čina, kojom lingvističke granice bivaju potpuno poništene.

Također, kritički se promatraju pomaci i odstupanja (Kristeva, 1981) u odnosu na pojam ženskog identiteta i ženskog pisanja (l'écriture féminine), te negiranja osobitosti ženskog pisma (Ellmann, 1986; Kolodny, 1975) i postojanja ženskog jezika (Cavarero, 1987).

Teorijski dio rada zaključuje se dekonstrukcijom pojma identitet, te dovođenjem u suodnos pojmova ženski identitet, nomadski subjekt i ženski identitet kao metafizički konstrukt, a potvrđuje se analizom djela Haraway (1995), koja odbija definirati muškost i ženskost, te prihvaća tezu o identitetu kao sociokulturološkom konstruktu, a ne biološki datom pojmu, Battersby (1998), koja vidi identitet u neprekidnoj fazi nadogradnje i rekonstrukcije, Braidotti (1994), koja na temelju filozofske rasprave o nomadologiji Gillesa Deleuzea i Félixa Guattarija iznosi tezu o ženskom subjektu kao nomadskom subjektu, o ženskom identitetu kao fluktuirajućem pojmu i ženskom pismu kao nomadskom pismu, te Butler (1990), koja, osvrčući se na Monique Wittig i njezinu teoriju o ženskome spolu kao jedinom predočenom u jeziku koji spaja žensko i spolno, istražuje načine na koje jezik gradi kategoriju spola.

Stekavši uvid u ovako složeno interdisciplinarno znanstveno područje, pristupa se primjeni u njemu teorijski utemeljene metodologije na odabrana djela Oriane Fallaci.

Kako se korpus odabranih Fallacinih djela oslanja na prethodna psihoanalitička i psiholingvistička istraživanja, odabiru se oni naslovi u kojima se odnos ženskog, ženstvenog i tekstualnog može najuvjerljivije prikazati: Il sesso inutile (1961), Penelope alla guerra (1962), Gli antipatici (1963), Se il sole muore (1965), Niente e così sia (1969), Quel giorno sulla luna (1970), Intervista con la storia (1974), Lettera a un bambino mai nato (1975), Un uomo (1979), Insciallah (1990).

Nakon sažetog pregleda nekih formalnih i sadržajnih karakteristika spomenutog opusa, te analize koncepta „retoričke slobode“ (Gatt-Rutter 1996, p. 21), u uskoj vezi s autoričinim biografskim kontekstom, kreće se u identifikaciju i analizu onih sintagmatskih i paradigmatskih elemenata koji Fallacine tekstove čine specifično ženstvenim. 
Prva skupina tekstova, Il sesso inutile (1961), Penelope alla guerra (1962), te Lettera a un bambino mai nato (1975), odnosi se na povezanost materijalnog tijela s tekstualnim prostorom, spolnog s jezičnim.

Fallacin disidentski subjektni položaj (Kristeva 1977b, p. 3-8), kao talijanske žene i Južnoeuropljanke u američkom, tada dominantno muškom, novinarskom sektoru, odredit će njezino marginalno i subverzivno, žensko i ženstveno, pismo i usmjeriti ga u pravcu vremenski i prostorno otvorenog sustava označivanja (Derrida 2007, p. 298-299). Suprotstavljajući se binarnim i bipolarnim strukturama falogokratičnog sustava, te faličkim i monolitnim sustavima znakova i Zakona (Lacan, 1983c), njezin antiedipski tekstualan prostor odsustva simboličkih autoriteta i potpune retoričke slobode, odiše spontanošću, pokretljivošću i varijabilnošću (Irigaray 1977, p. 109-110).

U antipatrijarhalnom i antiinstitucionalnom heterogenom jezičnom matriksu (Cixous 1975a, p. 258-259), koji obilježavaju mnogostruka preklapanja različitih stilova i registara, ekstradijegetskog i intradijegetskog, tjelesnog i tekstualnog, stvarnosti i fikcije, izgovorenog i pisanog, kao i morfosintaktička fragmentiranost, te leksička i fonetska repeticija, kumulacija i emfatičnost (Cixous, 1975b), odjekuju zvuci „majčinog prajezika“ (Cixous 1975c, p. 162), fluidnog i viskoznog prededipskog jezika ispunjenog ženskim glasom (p. 172). Тa prededipska povezanost materijalnog tijela (ženskosti), fizičke materijalizacije autoričinog glasa (ženstvenosti) s tekstualnim prostorom, brišući granice tjelesnog i psihološkog, fizičkog i metafizičkog, Fallacinu žensku i ženstvenu retoriku označava kao foničnu i taktilnu (Irigaray 1977, p. 76), heterogenu i biseksualnu (Cixous 1975b, p. 254).

Fallacina „biseksualna tekstualna strategija“, kojom Cixous označava ženstvenu antifaličku kreativnost, seksualno pretvara u tekstualno, a tekstualno u seksualno (p. 254). Patrijarhalno područje krutih jezičnih zakona, edipskog totalitarizma i hegemonije Fallaci zamjenjuje erotogenim heterogenim područjem potpunog opuštanja libidnih poriva (p. 260), područjem kojim dominira karnalna materijalizacija ženskoga glasa. Njezino prededipsko pismo, osobito izraženo u prvoj skupini tekstova, čin pisanja predstavlja kao govorni, dakle tjelesan, čin, kao medij putem kojeg autorica materijalizira vlastitu seksualnost.

Razmatrajući ženstveno pismo kao trenutak u kojem žensko tijelo progovara, na primjeru Fallacinog teksta Lettera a un bambino mai nato (1975), Gatt-Rutter (1996, p. 63) iznosi tezu o tzv. placentalnoj retorici, u metaforičkom ključu, o intimnoj komunikaciji autorice i teksta, 
o razgovoru koji putuje biološkim tkivima i tjelesnim tekućinama. Taj imaginarni prostor fluida i zvuka, u kojem glas nadvladava znak, simbol je retoričke slobode, izlaska ženskog i ženstvenog pisma u prostor koji izmiče označiteljskom.

U sljedećoj skupini tekstova, Gli antipatici (1963), Se il sole muore (1965), Quel giorno sulla luna (1970), te Intervista con la storia (1974), razmatraju se neke osnovne karakteristike Fallacine otvorene tekstualnosti, diskurzivne metode koja rigidne i zatvorene jezične sustave zamjenjuje otvorenim i polimorfnim lingvističkim sustavom. U ovim je tekstovima, nastalima u razdoblju velikog svjetskog kontrakulturnog pokreta, borbi za ljudska i građanska prava, te masovnih pobuna protiv autoritarnosti i hegemonije svih oblika razvidan autoričin otpor političkim i jezičnim falocentričnim strukturama moći.

Proučavajući kreativnu psihodinamiku Fallacine otvorene i oslobođene tekstualnosti, kojom je šezdesetih i sedamdesetih godina uvelike odudarala od svojih pretežito muških kolega novinara (Emerson 1980, p. 334), dolazi se do spoznaje o izraženoj prisutnosti nekih komparativnih prednosti ženskoga spola, poput intuicije, empatije i sposobnosti afektivne fuzije (Jung, 1971), uz pomoć kojih autorica uspješno penetrira, secira i otvara (Sanford 1975, p. 102) morfosintaktičke i leksičke strukture, povezujući, na taj način, ekstratekstualno i intratekstualno, govor i pismo. Fallacini nekonvencionalni novinarski članci (Aricò 1998, p. 156), natopljeni osobnim psihološkim otiskom i energijom libidne ženstvenosti, potvrđuju tako autoričinu subverzivnu percepciju lingvističkih granica, te jasno usmjerenu autoprojekciju svog, ženskog i ženstvenog, glasa.

Posljednja skupina tekstova, kojoj pripadaju tri opsežna romana s temom u zoni konflikta i revolucije, roman o vijetnamskom sukobu Niente e così sia (1969), roman o junaku grčkoga pokreta otpora, Fallacinom životnom partneru Alekosu Panagulisu, Un uomo (1979), te roman o libanonskom multietničkom sukobu Insciallah (1990), Fallacin koncept moralne, političke i jezične slobode razvija do gotovo krajnjih granica.

Autoričin sociolingvistički, disidentski i subverzivan, subjektni položaj, kojim svoju ženskost i ženstvenost potvrđuje kao fluktuirajuće, heterogene i tranzicijske psihofiziološke oblike, u velikoj mjeri manifestira i neke temeljne karakteristike nomadske estetike, fenomena „intenzivnog putovanja u mjestu“ (Deleuze i Guattari, 1986), svojevrsnog psiholingvističkog otpora prema etabliranim strukturama Zapadnog sustava. Njezina politička uvjerenja i stavovi, kontinuirana geografska tranzicija i samovoljno izbjeglištvo, ostavit će trajne 
posljedice na njezino pismo. Kao nomadski subjekt (Braidotti, 2002), ženski subjekt u procesu neprekidnog reoblikovanja i reinterpretacije (p. 13), njegovat će otvoren, neformalan i multidisciplinaran jezični stil, kojim će se, još jednom, jasno suprotstaviti trajnim političkim definicijama, lingvističkim normama i uzusima, falogokratičnim dogmama i režimima moći. Njezin nomadski uskus, izražen afinitet prema egzotičnim i udaljenim multikulturalnim nomadskim prostorima, pustinjama, tamnicama i zatvorskim ćelijama, područjima gdje se vrijeme i prostorne udaljenosti preklapaju i gube, u velikoj se mjeri reperkutira na jasno određenu antiedipsku retoriku. Ta „lingvistički promiskuitetna“ (p. 29) retorika tranzicije i transgresije na različite će načine utisnuti tragove nomadskog autorskog pera.

U Niente e così sia (1969) bit će najevidentnija na razini strukture i pripovijedanja. Krojenjem teksta po principu postmodernističkog bricolagea, umetanjem fragmenata međusobno različitih pisanih oblika, dnevničkih bilješki, novinarskih članaka i fikcije, doći će do fuzije i konfuzije lingvističkih i narativnih struktura, do kontinuiranog preplitanja intradijegetskog i ekstradijegetskog, a sve će se dodatno zakomplicirati ubacivanjem lingvističkih tehnika slobodnoga govornog čina, čime će se, u čitatelja, stvoriti osjećaj autoričine ontološke prisutnosti.

U prikrivenoj autobiografiji Un uomo (1979), biografskom romanu-dnevniku o ljubljenom i tragično preminulom muškarcu, izbodenoj kodovima ženskog i ženstvenog (Aricò 1998, p. 187), manifestirat će se u terminima biografske i autobiografske subverzije, odnosno lingvističke travestije autorice u glavni lik i pripovjedača, u subjekta i objekta teksta, čime će se potvrditi Manove (1984) izjave o autobiografskom subjektu kao retoričkom konstruktu koji se ustanovljuje procesom čitanja, trenutkom u kojem subjekt teksta i subjekt čitanja neprestance zamjenjuju svoja mjesta, Gusdorfove (1991, p. 10) teze o činu pisanja (graphie) kao činu koji autoru omogućava rekonstrukciju vlastitog sebe (auto/bio), odnosno pretpostavke Rosi Braidotti (2002, p. 32) o konstituciji nomadskog subjekta unutar jezika.

U impoznatnom ratnom triptihu Insciallah (1990) nomadska će se retorika, u najvećoj mjeri, otkriti na razini leksika i sintakse, a obilježit će ju snažno izražena lingvistička deteritorijalizacija (p. 36), te translingvalna i transkulturalna transpozicija (p. 37), sve tri u funkciji isticanja umnožive heterogene različitosti jezika (Derrida 2007, p. 298-299). U ovom, prema mišljenju mnogih kritičara, najuspješnijem Fallacinom romanu, gotovo potpunom negacijom „tiranskog režima Jednog“ (p. 29), odmičući od kulturnog i lingvističkog 
puritanizma i etnocentrizma (Said, 1987), demistificirajući i dekonstruirajući krut i monolitan sustav institucionaliziranih standardnih jezika, približavajući se govornom stilu i neformalnim jezičnim registrima, autorica jasno pomiče lingvističke granice teksta, pomičući istodobno i one rasne, klasne, etničke i spolne, ulazeći, na taj način, u nomadski prostor političke, kulturne i jezične slobode.

Naposljetku, istraživanje se zaključuje jasnim ukazivanjem na neke od temeljnih osobitosti Ženske osobnosti, ženskog i ženstvenog govora, ženskog i ženstvenog pisma, te utjecaja prirode i kulture na potonje, a konačne se spoznaje praktično primjenjuju na pojedina izabrana djela Oriane Fallaci, te se u njima objašnjava prisutnost ženskog tijela, ženskog i ženstvenog glasa, kao i ženske i ženstvene kreativne strategije. 


\section{DIO}

TEORIJSKE REFLEKSIJE: SPOLNO, RODNO, JEZIČNO 


\section{O ŽENSKOM SUBJEKTU}

\section{I. ŽENA KAO „DRUGO“}

\section{I. I. Frojdovska psihoanaliza}

Proučavanje histerije, kao primarno ženskog neurotskog poremećaja, na neki je način dovelo i do samog razvoja psihoanalize. Ne bi li iznova dokučio taj „tamni kontinent“, izraz koji je često koristio, Freud se teoriji ženskog uvijek iznova vraćao. Njegovi najpoznatiji tekstovi u kojima se osvrće na pitanje ženskog su: O najčešćem obliku degradacije ljubavnog života (1912), Prilog uvodu u narcizam (1914), Tabu djevičanstva (1918), Razrješenje Edipovog kompleksa (1924), O nekim psihičkim posljedicama anatomske razlike među spolovima (1925), O ženskoj seksualnosti (1931) te Ženskost (1933), dio Novih predavanja za uvod u psihoanalizu. Iako Freuda, poglavito feministice, često optužuju za mizoginiju, valja istaknuti kako su takve optužbe najčešće posljedica površnih analiza njegovih tekstova. Naime, u tekstu Freud on women Nancy Chodorow objašnjava kako je upravo Freud dao ženama pravo glasa. Neurotične su pacijentice prepričavale vlastite priče, snove, sjećanja i neispunjene fantazije, a ti su lječnički zapisi, ušavši u tekst pod nazivom Studije o histeriji, prvi dokaz o ,izravnoj obrani histeričnih žena i njegovoj osudi okolnosti koje vode do potiskivanja i histerije u žena“" (Chodorow 1991, p. 246). Prema mišljenju autorice, Freud je uputio snažnu kritiku društvu koje žene kulturno ograničava, te kazao kako takva vrsta kolektivne pasivne agresije dovodi žene do potiskivanja i histerije. Chodorow spominje $\mathrm{i}$ Freudov rani članak Kulturni seksualni moral i moderna nervoznost iz 1908., u kojem je također iznesena vrlo snažna kritika društvenih ograničenja, koja su kroz stoljeća nametnuta ženama. I u ovom tekstu Freud optužuje muškarce jer su stvorili okolnosti kako bi žene od samih početaka imale ulogu pasivnog i podređenog.

Za šire i kvalitetnije razumijevanje Freudove teorije ženskosti ključna je rasprava istoimenog naziva Ženskost (1933), koju Freud započinje nizom retoričkih pitanja o definiciji spolnosti i o tome što je nužno da bismo nešto definirali kao žensko ili kao muško biće. S tim u vezi, nailazimo na prvi propust feminističkih teoretičarki, a to je Freudovo priznanje kako je ljudska priroda biseksualna. Dijelovi muškog spolnog aparata, ističe Freud, nalaze se i u tijelu 
žene, iako u zakržljalom stanju, i obratno. Svatko od nas nije, tako, ni posve muško, ni žensko, već u svakom slučaju i jedno i drugo, samo što mnogo više ima jednog nego drugog. Također, smatra kako anatomske razlike nisu dovoljne da bi nešto okarakterizirali kao muško ili žensko, zaključujući kako je ono što čini muškost ili ženskost njemu još uvijek nepoznata odlika (Freud 2006, p. 404). U tom smislu, pojam biseksualnosti Freud je prenio i na duševni život te se često bavio proučavanjima raznih utjecaja koji su doveli do prihvaćanja određenih konvencija koje, s druge strane, prate konzervativnu struku i prikazuju ljudska bića isključivo na temelju njihovih anatomskih razlika. Spolnost i anatomske razlike, međutim, uvjetovat će ipak u jednoj određenoj mjeri i ponašanje muške odnosno ženske jedinke. Muška spolna stanica aktivno je pokretna i kreće se tražeći kao konačni cilj žensku jajnu stanicu, koja je potpuno nepokretna i čeka da bude oplođena. Takvo ponašanje spolnih stanica nacrt je ponašanja jedinki dvaju spola prilikom seksualnog općenja. Mužjak preuzima inicijativu, a ženka to pasivno podnosi i dopušta. $\mathrm{Na}$ takvu, prirodom određenu, pasivnu funkciju žene, društvo i socijalni poredak nadograđuju niz raznih konvencija i normi koje, primjećuje Freud, ženu dodatno guraju u pasivan položaj (p. 405). Supresija nagonskog života i zdrave agresije, koje nameće okolina, dovodi do razvoja snažnih mazohističkih težnji kod žena, a erotske autodestruktivne tendencije postaju tako jedno od glavnih obilježja ženskosti i ženskog karaktera.

Žensku je prirodu Freud u određenoj mjeri spojio s nagonskim životom te ženu kao takvu okarakterizirao kao manje agresivno biće, prkosno i samozadovoljno, zavidno i labilno, narcistički nastrojeno, naučeno da osjeća i iskazuje stid, sa znatno umanjenom sposobnošću sublimacije i osjećaja za pravdu, ali i uvećanom potrebom za interakcijom s vanjskim svijetom. Sve ove osnovne karakteristike ženske osobnosti Freud je vezao uz dva ključna razvojna elementa seksualnog života žene: prededipsko razdoblje djevojčice u kojem je ona još uvijek vezana uz majku, te edipsko razdoblje unutar kojeg dominiraju osjećaji zavisti, straha od separacije i seksualne inferiornosti koja, dodaje Freud, djevojčicu nastavlja dalje pratiti kroz cijeli njezin život. Prededipsko vrijeme, vrijeme obilježeno dijadnim odnosom majke i djeteta, u dječaka biva razoreno kompleksom kastracije. Dječak, koji je vidio ženski spolni organ, uviđa kako penis ne mora nužno biti sastavni dio ljudskog tijela: ,tada se sjeća prijetnji koje je slušao dok se igrao svojim udom, počinje u njih vjerovati, i pada pod utjecaj straha od kastracije, koji postaje najmoćnijim pokretačem njegovog daljnjeg razvoja“ (p. 412). U djevojčica je situacija ponešto drugačija. Edipska faza i nju obuhvaća, no ona se 
osjeća potpuno drugačije, osjeća se teško oštećena, osjeća stid i manjkavost. U konačnici, te će je emocije dovesti do razvoja snažnog osjećaja zavisti, emocije koja će ostati duboko ukorijenjena u nesvjesnom prostoru, ostavljajući neuništive tragove u razvoju i formiranju karaktera, a njezinom će žrtvom, ističe Freud, ostati do kraja života (p. 412). Freud smatra da su osjećaji poput zavisti, ljubomore, kompeticije, upravo iz jednog evolucijskog aspekta, izraženiji u žena nego u muškaraca, a u duhovnom životu žene igraju značajnu ulogu. Kastracijska prijetnja, dio faze falusne seksualnosti, oslobađa muško dijete Edipovog kompleksa i vezanosti uz majku. U njemu se incestne želje potiskuju, u najnormalnijem slučaju i potpuno razaraju, te dolazi do formiranja Nad-Ja. U djevojčica, međutim, zbiva se potpuno suprotno. Djevojčica izlazi iz dijadnog odnosa s majkom, no zbog osjećaja zavisti na penisu njoj edipska situacija, na neki način, pruža sigurno utočište. Budući da je ne goni strah da će biti kastrirana, kao što je to slučaj u dječaka, nedostaje joj glavni motiv koji bi je naveo da nadvlada edipsku situaciju. U edipskoj fazi djevojčice ostaju mnogo dulje, vrlo je kasno razaraju, a često i nepotpuno. Pod takvim okolnostima, ističe Freud, mora stradati formiranje Nad-Ja: „on ne može postići onu snagu i neovisnost koju mu daje kasnije njegov značaj u kulturi“ (p. 415). Pomanjkanje jačine i kompaktnosti nad strukture psihičkog aparata u žena čini ih ranjivijima i ovisnijima, a njihovu sposobnost da sublimiraju vlastite nagone znatno umanjuje. Narcizam i slabo razvijen osjećaj za pravdu također su osnovne crte ženskog karaktera, navodi Freud. Zbog zavisti, koju žena nosi sa sobom još od edipskog razdoblja, izbor objekata igrat će ključnu ulogu u njezinom daljnjem životu. Kako bi se, na neki način, obeštetila, žena će cijeli život hraniti svoju nezasitnu taštinu i investirat će neumorno u vlastiti izgled. Uvijek će joj biti potrebnije da bude voljena, nego da voli, zaključuje Freud.

Strahu od smrti još je jedan pridodan strah - otkriće o radikalnoj drugosti ženskog bića, ističe u svojoj knjizi Zagonetka žene: žena u Freudovim spisima ${ }^{1}$ Sarah Kofman. Autorica vlastitim riječima sažima bit ženskog iz cijelog Freudova opusa, a raspravu započinje braneći njegove stavove, smatrajući kako su vrlo često krivo ili površno tumačeni. Priroda ženske seksualnosti čini ženu zagonetnom i tajanstvenom, no to nipošto ne znači da je bit ženskog sažeta i reducirana na seksualnost. Naprotiv, sam se Freud u eseju Ženskost od takvih interpretacija ogradio i više puta istakao kako je nastojao opisati ženu samo u onoj mjeri u kojoj seksualna funkcija određuje njezinu prirodu. Također, zaključio je kako sama psihoanaliza nije dovoljna da bismo otkrili enigmu žene, a vlastite tekstove i razmatranja o

\footnotetext{
${ }^{1}$ The Enigma of Woman: Woman in Freud's Writings (1985).
} 
ženskosti kasnije je smatrao nepotpunim i fragmentarnim. Kofman također naglašava kako je Freudovo istraživanje ženskog bio izuzetno težak zadatak iz nekoliko razloga. Osim što je ženska seksualnost složenija od muške, ona je i mnogo manje dostupna konkretnim istraživanjima. Naime, žena ima slabiji seksualni život, ona je u gotovo atrofiranom stanju ${ }^{2}$, od samih početaka nastanka civilizacije. Zbog niza kulturnih ograničenja, žena govori manje slobodno o svojoj seksualnosti nego li muškarac, a društvo i okolina čine skromnost i osjećaj stida temeljnim ženskim vrlinama. Skrušen i rezerviran način govora o sebi i vlastitoj intimi dovelo je ženu u poziciju zanemarenog submisivnog subjekta (Kofman 1985, p. 39-41). U poglavlju naslovljenom Narcistička žena (1985, p. 50-65) Kofman nas upućuje na Freudov tekst Prilog uvodu u narcizam (1914), kojim autor objašnjava osnovne razlike između muškog i ženskog spola prema tipu objektnog izbora. Potpuna objektna ljubav karakteristična je za muškarca, ističe Freud. U stanju zaljubljenosti događa se prijenos prvobitnog narcizma na voljeni/seksualni objekt. Takvo objektno precjenjivanje omogućava da se razvije stanje zaljubljenosti i ushita, koje podsjeća gotovo na neurotsku prisilu. U tom se slučaju događa osiromašenje libida u $J a$, na račun objekta (Freud 1986, p. 56). Žene, međutim, osobito ako su lijepe, razvijaju određenu mjeru samozadovljstva (Selbstgenügsamkeit) što je nadoknada za društvena ograničenja koja su im nametnuta: „Takve žene vole isključivo sebe, sličnom intenzivnošću kojom muškarac voli njih. Njihova potreba nije da vole, nego da budu voljene“ (Freud 1986, p. 57). Upravo ovaj momenat Kofman drži ključnim, jer ono što sad ženu čini zagonetnom nije više manjak, već njezina narcistička zaljubljenost u sebe samu, njezina ravnodušnost i pozicija one kojoj muškarac zavidi: „,nije više žena ta koja zavidi muškarcu na penisu, nego on njoj zavidi na njezinu libidnom položaju koji ne može doseći, dok je on ispražnjen od svog narcizma“" (p. 52). Kofman ističe kako muškarca privlači ženi upravo taj prvobitni narcizam koji je on izgubio i prema kojem stalno osjeća nostalgiju. U tom smislu, Freudov tekst o narcizmu ukazuje na jedno alternativno viđenje ženskosti, kakvo je često zanemareno, a to je slika ženske svemoći, u odnosu na sliku ženske nemoći, na kakvu najčešće nailazimo u interpretacijama Freudovih tekstova. Prikaz žene kao jačeg spola Kofman završava Freudovim manje poznatim tekstom iz 1918. Tabu djevičanstva ${ }^{3}$, u kojem autor govori o primitivnom čovjeku koji uspostavlja tabu djevičanstva, osjećajući strah, opasnost i nadmoć žene: „ono što muškarca osobito uznemirava i zastrašuje jest to da ga žena

\footnotetext{
${ }^{2}$ Atrophied condition (Kofman 1985, p. 39).

${ }^{3}$ U Totem i tabu (1918).
} 
ne oslabi, da ga ne inficira svojom ženskošću, da ga ne učini nemoćnim, što jest utjecaj koji žena može imati nad muškarcem u spolnom činu“ (Kofman 1985, p. 68). Kofman, međutim, navodi kako Freud tvrdi još nešto, a to je da najdublji motiv za tabu djevičanstva leži zapravo u ženskoj zavisti na penisu, što potječe iz kastracijskog kompleksa. Te se zavisti muškarac boji jer se iz nje rađa neprijateljska ogorčenost žene. Kako se osjeća prevarenom, od prirode i vlastite majke, žena se u prvoj bračnoj noći osvećuje - kastrirajući muškarca. U tom smislu, ženska nedozrela spolnost omogućuje muškarcima da se prepuste manipulaciji žena bez opasnosti: „cijela operacija tog teksta sastoji se od lišavanja žene-zmije njezine strašne moći i pridavanju ženi jednostavne nezrele seksualnosti. A ime te operacije je kastracija“ (p. 70). Iz svega navedenog, zaključujemo kako Freud ne promatra ženu kao inferiorno biće. Za njega je žena drugačiji spol, ne spol drugog reda. Ona nije nemoćan spol, ona je spol moći i utjecaja. Ona lišava muškarce njihove snage, a kako bi izbjegli njezinu dominaciju i supremaciju, muškarci postavljaju niz prepreka, društvenih konvencija i kulturnih ograničenja.

Možda najkontroverzniji psihoanalitičar, koji je, nakon Freuda, dao značajan doprinos psihoanalizi i filozofiji, francuski je psihijatar Jacques Lacan. Od 1953. do 1981. Lacan je u Parizu održavao godišnje seminare koji su šezdesetih i sedamdesetih godina utjecali na francuske intelektualce, naročito na poststrukturaliste. Radeći interdisciplinarno i na tragu Freuda, bavio se pitanjima nesvjesnog, straha od kastracije, ega, identifikacije i jezika kao subjektivne percepcije. Lacanove ideje značajno su utjecale na kritičku teoriju Frankfurtske škole, teoriju književnosti, francusku filozofiju 20. stoljeća, sociologiju i feminističku teoriju. Središnja je ideja njegove koncepcije ljudskog bića da je nesvjesno, koje vlada svim faktorima ljudskog postojanja, izgrađeno poput jezika, a njime vladaju dva osnovna mehanizma: zgusnuće i pomak, oboje lingvistički fenomeni. Nesvjesno, dakle, nije kaotična kanta za otpad, već prostor kojim vladaju precizni jezični zakoni, koji imaju svoj logičan slijed, svoju gramatičku i retoričku konstrukciju.

Lacan je Freudovu teoriju Edipovog kompleksa, na vrlo osebujan način, reformulirao. On u svojim najranijim radovima u potpunosti usvaja Freudove teze, no pedesetih godina, pod vrlo snažnim utjecajem Lévi-Straussovog strukturalizma, razvija vlastitu inačicu teorije edipskog sukoba. Za Lacana edipski odnos predstavlja trodimenzionalnu simboličku strukturu: „Edipov kompleks predstavlja trokutastu strukturu koja razbija dualni odnos majke i djeteta unutar imaginarnog“ (Homer 2005, p. 53). Lacanova se teza temelji prvenstveno na posve drugačijoj artikulaciji trostruke topografije čovjekove duševnosti; za razliku od Freuda koji govori o 
nesvjesnom, predsvjesnom i svjesnom, odnosno o pojmovima Id, Ego te Superego ${ }^{4}$, Lacan govori o tzv. psihičkim registrima ${ }^{5}$, odnosno o područjima Imaginarnog, Simboličkog i Realnog. Imaginarno predstavlja registar destabilizacije i odgovara prededipskom vremenu tijekom kojeg dijete isključivo biva vezano uz majku te između sebe i nje još uvijek ne zamjećuje razliku. Izlazak iz područja imaginarnog podrazumijeva ulazak u prostor simboličkog, u prostor varke (Meconnaissance/Misrecognition ${ }^{6}$ ), koji se sastoji od Le Moi $\left(\mathrm{Ego}^{7}\right)$ i Je $(\mathrm{Ja})$, a predstavlja „,edipsku krizu“ unutar koje se stječu jezik i nesvjesno (Homer 2005, p. 25). Od tog trenutka imaginarno jedinstvo koje je dijete imalo s majkom mora biti prekinuto, a njega prekida zakon Oca, odnosno Ime Oca/Očeva Zabrana (Le Nom du Père/Le Non du Père $)^{8}$ koji označava simbol kastracijskog straha. Stoga ulazak u Simboličko znači prihvaćanje znaka falusa (zakona $O c a$ ):

\begin{abstract}
Za Lacana je uvođenje simboličkog, zakona, a poslije i Imena Oca vezano uz označiteljsku ulogu falusa i kompleks kastracije. Lacanova teorija seksualnog identiteta, njegova verzija Edipovog kompleksa i uspostava Simboličkog mogu se povezati preko koncepta falusa. (Matijašević 2006, p. 132)
\end{abstract}

Zapadna su društva i kulture obilježene simboličkim poretkom te znakom falusa, u njima je Otac nositelj primarnog zakona zabrane incesta te onaj koji otvara vrata simboličkog svijeta, odnosno, Lévi-Straussovim rječnikom, otvara vrata jezika i kulture. Ukoliko subjekt ne prihvati ovaj red i ostane zarobljen u imaginarnoj simbiotskoj vezi, ostat će obuzet strastima opsesivno nezadovoljive žudnje (Lacan 1992, p. 17). Žudnja (Le Désir) za Lacana je termin od ključne važnosti - ona je, na neki način, središnja funkcija unutar simboličkog, spiritus movens simboličkog poretka, a motivirana je isključivo pronalaženjem Realnog: „žudnja se

\footnotetext{
${ }^{4}$ Poznato je da je prvi Freudov topografski model psihičkog aparata bio podijeljen na: nesvjesno, predsvjesno i svjesno i njega izlaže godine 1900. u VII. poglavlju knjige Tumačenje snova, dok je drugi Freudov model psihičkog aparata, tzv. strukturni model, podijeljen na: Id, Ego i Superego (Nad-Ja) i njega počinje razvijati nakon godine 1920. (Laplanche; Pontalis 2010, p. 634).

${ }^{5}$ Područja iz kojih pojedini stadiji psihičke ličnosti vuku svoj sadržaj.

${ }^{6}$ Termin je vezan uz teoriju o stadiju zrcala. Ono što spoznajemo u zrcalu jest varka.

7 Pandan Freudovom shvaćanju ega. Naime, protiveći se ego-psiholozima koji, veličajući snagu ega, potiču narcizam, i želeći ego vratiti Idu, Lacan potvrđuje izvornu Freudovu tezu ,ego je fragilan i potječe iz Ida“.

${ }^{8}$ Zakon Oca predstavlja za dijete simbolički označiteljski rez, koji ga iz svijeta imaginarnog uvodi u onaj simbolički. Lacan inzistira na različitoj terminologiji naglašavajući tako činjenicu kako se ovdje ne radi o stvarnim osobama, nego isključivo o simboličkoj poziciji objekta djetetove žudnje, o poziciji autoriteta i simboličkom zakonu koji intervenira u zabrani djetetove žudnje (Homer 2005, p. 53).
} 
pokazuje kao nemogućnost zadovoljenja koje se odvija na pozadini Realnog“ (Matijašević 2006, p. 168). Prostor realnog označen je terminom Jouissance (užitak) i označava prostor izvan/onkraj jezika, prostor koji izmiče „označiteljskom“, prostor koji simbolički poredak nije mogao integrirati. Njime Lacan tumači i muško-žensku dijalektiku seksualnosti, ističući kako upravo ženska seksualnost izmiče označiteljskom i stoga je ona nefalična i gotovo nepotpuna (Lacan, 2017). Lacan, dakle, govori o ulasku u simbolički poredak unutar kojeg se događa zamjena objekata žudnje - žudnja se s majke premješta na položaj koji uvodi novi poredak: Ime Oca. Nastup zabrane incesta, koji se podudara s Edipovim kompleksom, istodobno dakle znači upad jezika, upad u svijet simboličkog. Time se konstituira subjekt. Taj ulazak jamči samostalnost ega koji je dosad bio ovisan o imaginarnim identifikacijama (postaje subjekt) i tek sada doista uspostavlja spolnu razliku. Taj trenutak istodobno označava i rođenje nesvjesnog, jer ulazak u simboličko ujedno je i izlazak iz raja simbioze. S tim je povezano i izvorno potiskivanje, prapotiskivanje, koje cijepa subjekt. Subjekt koji je sada otcijepljen od svoje primarne želje, od svoje imaginarne identifikacije, odsada je najprije $\mathrm{Ja}(\mathrm{Je})$ kojega obilježava neki manjak: gubitak imaginarnog jedinstva $\mathrm{s}$ majkom, gubitak objekta $a$. Kastracijski čin, prema mišljenju Lacana, od odlučujuće je važnosti za uspostavljanje reda i reguliranje seksualnog života. Nužan je za shvaćanje vlastitih, ali i tuđih, potreba. Putem ove antinomije $^{9}$, čovjekova seksualnost sazrijeva, no ostaje i dalje sporan Lacanov zaključak o ženskom genitalnom sazrijevanju, kojim potvrđuje Freudove teze o prevlasti falusnog svojstva, u smislu seksualnog užitka, tako da žena i dalje ostaje obilježena kao ,prostor seksualnog prodora“ (Lacan 1983a, p. 255-257).

U sklopu genitalnog sazrijevanja, Lacan je 1936. započeo raditi na još jednoj teoriji - teoriji o stadiju zrcala. Ubrzo ju je pokušao izložiti na konferenciji u Marienbadu, no kako tada za nju nitko od prisutnih ne pokazuje razumijevanje i interes, službeno ju odlučuje objaviti tek 1949. ${ }^{10}$ Stadij zrcala otvara se poljem imaginarnog, ističe Lacan. Između šestog i osamnaestog mjeseca života, dijete pokazuje neobično veliko zanimanje za svoju sliku u zrcalu. Tumačenje toga Lacan će ponuditi u konstataciji da dijete u toj slici najednom prepoznaje sebe samoga kao cjelinu. Prije nego je došlo do toga djetetova je svijest bila

\footnotetext{
${ }^{9}$ Svojstva drugoga spola usvajamo putem prijetnje i odricanja.

${ }^{10} \mathrm{~S}$ manjim doradama sve do šezdesetih godina.
} 
rascijepljena, dijete je osjećalo da nije jedinstveno, da je raskomadano (corps morcelét ${ }^{11}$ ). Poistovjećivalo se s majčinim licem, ali i s drugim predmetima. U toj fazi dijete ne zna da je nešto drugo od okoline, od onoga što zamjećuje oko sebe. No kad ugleda svoju sliku u zrcalu (ili drugo dijete svoje starosti koje mu je slično), dijete se u njoj odjednom prepoznaje, „zadobiva“ svoj identitet. Ta situacija za djetetovo oblikovanje ima presudnu posljedicu: slika u zrcalu je doista njegova, no istodobno je slika nekoga drugoga, budući da je potpuna. A on je naime (još uvijek) manjkav. Upravo zbog te razlike između punoće i manjkavosti ta će ga slika preuzeti i dijete će se s njom identificirati. Otuda Lacanova misao da je imaginarna identifikacija sa slikom drugoga konstitutivna za $\mathrm{Ja}$ : „funkcija stadijuma ogledala pokazuje nam se kao poseban slučaj funkcije imago, koja se sastoji od ustanovljavanja odnosa organizma s njegovom realnošću - ili, kako se kaže, odnosa Innenwelta sa Umweltom“ (Lacan 1983b, p. 9). U terminima psihičkih registara, imaginarna je faza znak da se samostalni $J a$ (ili subjekt) još nije razvio. Da bi se to dogodilo, mora nastupiti nova faza, faza simboličkog. Tada u dualni odnos između $J a$ i njegovog objekta (zrcalne slike), malog drugog $\boldsymbol{a}$, kako ga naziva Lacan, preko drame edipovog kompleksa, stupa treći veliki drugi A. To je otac, odnosno, Ime Oca.

U Lacanovoj teoriji stadij zrcala poprima veliku važnost. Njime on otkriva stvarnu poziciju ega, u smislu da je zrcalni stadij mjesto konstitucije samoga ega. I prema njegovom mišljenju, niz problematika, vezanih uz neurotske pomake, poput agresivnog ponašanja, narcizma i paranoje, proizlazi iz problematike zrcaljenja/poistovjećivanja, odnosno sukoba ega s našim $J a$. No, do upitnosti ove teorije dolazi kada je u pitanju njegova uloga u tvorbi identiteta, na čemu je Lacan inzistirao. Iako je tema zrcaljenja dugo bila zanimljiva, osobito teoretičarima objektnih odnosa, koji govore o zrcaljenju djeteta u majčinom licu, za suvremenu psihoanalizu vizualna dimenzija nije jedina ključna kada je u pitanju identitet. Majčin dodir, glas i toplina za suvremenu su znanost jednako važni i jednako sudjeluju u formiranju identiteta. Ono što, međutim, svakako treba istaknuti jest činjenica da se Sebstvo konstituira u odnosu na druge objekte. Oni su od iznimno velike važnosti za potvrđivanje i priznanje, za rast.

\footnotetext{
${ }^{11}$ Termin kojim Lacan označava djetetovo poimanje vlastitog tijela kao svojevrsnu ortopedsku konstrukciju, kao vizualnu protezu svog zrcalnog odraza (Lacan, 1983b).
} 


\section{I. II. Postfrojdovska psihoanaliza}

Pojam edipskog sukoba ostaje vezan uz frojdovsku psihoanalizu. Objašnjavajući ključan stadij seksualnog sazrijevanja i formiranja identiteta isključivo muškog djeteta, ostaje i dalje upitna njegova primjena na teoriju ženskog sazrijevanja. Žena, u frojdovskom smislu, ostaje i dalje na margini, isključena iz edipskog trokuta. Ipak, četrdesetih godina među brojnim psihoanalitičarima počinje se sve više govoriti o prededipskom vremenu razvoja i njegovom utjecaju na formiranje ličnosti i identiteta, te na ulozi žene kao majke. Proučavanje prededipskog vezano je uz područje postfrojdovske psihoanalize, tj. uz Melanie Klein te Školu objektnih odnosa ${ }^{12}$. Prededipsko vrijeme, kako termin objašnjava, prethodi edipskom vremenu: prije uspostave edipskog trokuta postoji vrijeme obilježeno dijadnim odnosom majke i djeteta, vrijeme u kojem je uloga oca mnogo manje važna (Laplanche i Pontalis 2010, p. 433-434). Osobito za teoretičare objektnih odnosa majka predstavlja prvi i najvažniji objekt (kako za muško, tako i za žensko dijete), stoga ključno razdoblje u razvoju muške i ženske seksualnosti, procesa individuacije te identifikacije, postaje ono prededipsko, ne više edipsko, a žena, odnosno majka, postaje ključan čimbenik odrastanja.

Matijašević ističe kako je najpoznatija varijanta prededipske teorije ona Melanie Klein i sadrži nekoliko važnih implikacija. Prije svega, Klein od Freuda preuzima podjelu nagona na Eros i Thanatos te njima objašnjava ambivalentan odnos majke i djeteta: dijete je fizički vezano uz majku (osobito je važan kontakt s majčinom dojkom), ovisi o majci i njezinoj pažnji, no i najmanje uskraćivanje te bezuvjetne pažnje u djetetu budi destruktivne osjećaje poput ljutnje i agresije (Matijašević 2011, p. 55). Također, prededipsko vrijeme, prema mišljenju Klein, sastoji se od dva temeljna položaja, a to su: paranoidno-shizoidni i depresivni položaj ${ }^{13}$. Oni predstavljaju najranije razvojne faze te su kao takvi presudni za stvaranje sposobnosti interakcije s drugim ljudima i okolinom u kasnijim godinama života (p. 56). Paranoidno-shizoidni položaj pojavljuje se u prvim mjesecima djetetova života, a obilježen je intenzivnim i destruktivnim afektima djeteta naspram majčinog tijela. $U$ toj fazi dijete

\footnotetext{
${ }^{12}$ Psihoanalitička Škola objektnih odnosa započela je svoj rad četrdesetih godina 20. st. u Velikoj Britaniji, nakon Freudove smrti. Tada je bila podijeljena u tri skupine: prva skupina razvijala je teorijske postavke Melanie Klein, druga je ostala vjerna Freudu i kasnije se razvila u ego psihologiju, a treća je izgradila vlastiti teorijski stup i danas nju smatramo Školom objektnih odnosa (njoj pripadaju Donald Winnicott, Michael Balint, Ronald Fairbairn). Ovim se prvim školama mogu pribrojiti i neke kasnije, manje, škole, poput one francuske (kojoj pripadaju Jean Laplanche i André Green), i neke druge, no ipak, one se u svojim teorijskim postavkama podosta razlikuju od izvornih škola (Durić 2013, p. 215-216).
}

\footnotetext{
${ }^{13}$ Pandan Kleinovoj podjeli bila bi Freudova podjela predgenitalnih libidnih stadija (oralni, analni i falusni).
} 
doživljava majčino tijelo raskomadano na dijelove ( cijepanje $^{14}$ ), što mu, s druge strane, omogućava prilagodbu u svijetu u kojem ovisi o drugima: ,prva tri mjeseca u djetetovu životu obilježena su svijetom koji se sastoji od dijelova stvarnoga svijeta koji pružaju zadovoljenje“ (Klein 1983, p. 66). Najvažniji dio tog svijeta svakako je majčina dojka: „ona je djelomični objekt od čijeg se gubitka najviše strahuje jer simbolički označava pažnju, ljubav, nježnost, dobrotu i zaštitu“ (Durić 2013, p. 204). Izuzetno je važno da se paranoidno-shizoidni položaj što bezbolnije prevlada, što će osigurati topao i ohrabrujuć odnos s majkom utemeljen na povjerenju, jer će tada dijete razviti sposobnost ulaska u sljedeći, depresivni, položaj. Depresivni položaj jednim svojim dijelom pripada prededipskom vremenu, a drugim ulazi u edipsku trijadu ${ }^{15}$. U tom položaju dolazi do integracije objekata (majčino se tijelo doživljava kao cjelina) te do postupne neutralizacije ambivalentnih nagona (Erosa i Thanatosa). Dok je Freud, u kontekstu edipacije, govorio o osjećaju ljubomore djeteta naspram roditelja suprotnog spola, Klein ljubomoru razlikuje od osjećaja zavisti. Zavist, vezana uz paranoidnoshizoidni položaj, potječe iz odnosa djeteta s majkom i njome dominiraju osjećaji bijesa jer druga osoba posjeduje ono za čime objekt teži. Ljubomora, s druge strane, potječe iz odnosa subjekta s dvama objektima ,od kojih se jedan voli, a drugi se poima kao prijetnja koja će oduzeti ljubav voljena objekta“ (Durić 2013, p. 211). Posve je očito kako je frojdovski koncept edipacije u teoriji Melanie Klein doživio veliki obrat, odnosno pomaknut je unatrag (kastracija je zamijenjena procesom dojenja kao odlučujućeg trenutka u oblikovanju sebstva). Prededipska identifikacija, prema mišljenju Klein, odigrava ključnu ulogu u razvoju djeteta, a mogući propusti u odnosu majka-dijete u tom razdoblju ostavit će snažne posljedice u kasnijim godinama života.

I za teoretičara objektnih odnosa Donalda Winnicotta, prededipska faza ključno je razdoblje u kojem biva oblikovano sebstvo. Freudova trokutasta struktura edipskog odnosa, koja uključuje dijete, majku i oca, zamijenjena je dijadnim odnosom majke i djeteta, a upravo taj odnos označen je kao objektni odnos. Za razliku od frojdovskog i lacanovskog pristupa, koji prvenstvo daje ocu, škola objektnih odnosa naglasak stavlja na majku i ,na njezine emocionalne kapacitete te odnos staranja naspram djeteta“ (Durić 2013, p. 217). To nikako ne znači da su ulogu oca teoretičari objektnih odnosa potpuno zanemarili. Ona, naime, ostaje i

\footnotetext{
${ }^{14}$ Temeljni prvobitni mehanizmi konstituiranja $J a$, preko interakcije s vanjskim objektima, jesu: cijepanje, introjekcija, projekcija te projektivna identifikacija (Matijašević 2011, p. 55).

${ }^{15}$ Dolazi do preraspoređivanja afekata prema drugim objektima osim majke [...] ulaskom trećeg u afektivni život djeteta (p. 57).
} 
dalje ključan čimbenik kasnijeg, edipskog, razdoblja, no dijadan odnos majke i djeteta, koji prethodi edipskom, ostaje najvažnije razdoblje u dječjem odrastanju. Winnicottove su teorijske postavke vrlo slične onima Melanie Klein, ipak, u nekim se ključnim točkama i znatno razlikuju. Winnicott (2004) smatra kako okoliš koji dijete okružuje odigrava jednako važnu ulogu u oblikovanju ega, baš kao i unutarnji psihički sustav. Polazeći od činjenice kako se dijete ne rađa s egom, već se ego oblikuje tijekom odnosa s majkom, Winnicott ističe kako su za razvoj ega nužni, prije svega, povoljni emocionalni i okolišni uvjeti, koji će tijekom vremena dovesti do konačne separacije i individuacije. Upravo iz tog razloga Winnicott se protivi teoriji Melanie Klein, prema kojoj se dijete rađa s urođenim destruktivnim impulsima, te u njegovoj teoriji objektnih odnosa važni postaju prijelazni objekt, prijelazni prostor te prijelazni fenomen. Svi oni označavaju stadij izlaza djeteta iz dijadnog odnosa s majkom, odnosno ulazak u vanjsku zbilju; dijete neposredno nakon odvajanja od dijadnog odnosa nije sposobno samostalno pojmiti stvarnost, pa uz pomoć prijelaznih objekata i prostora počinje shvaćati svijet oko sebe ${ }^{16}$ : „Prijelazni objekti i prijelazni fenomeni spadaju u područje iluzije koje je temelj uvođenja u iskustvo. Ovu ranu fazu u razvoju omogućuje majčina osobita sposobnost da se prilagođava potrebama svog djeteta i tako pruža iluziju da to što ono stvara zaista i postoji“ (Winnicott 2004, p. 30). No, da bi dijete uopće moglo razviti sve kapacitete za poimanje zbilje, vrlo je važno da dijadan odnos majke i djeteta bude topao i ohrabrujuć za dijete:

\begin{abstract}
Izloženost neadekvatnom majčinom ponašanju može dovesti do traumatizma, straha i anksioznosti te poistovjećivanja putem oponašanja, čime pravo sebstvo ostaje skriveno i neostvareno. Ako je majka odveć emocionalno hladna i nezainteresirana, odnosno ako je lišavanje odveć intenzivno, a okruženje neprijateljsko, dijete ne može razviti kapacitete za testiranje stvarnosti. Kako je ego još uvijek nerazvijen, prerano se suočava sa zahtjevima vanjske stvarnosti, što dovodi do razvoja lažnog sebstva te neispunjavanja potencijalnih kapaciteta pojedinca. (Durić 2013, p. 224)
\end{abstract}

U tom smislu, Winnicottovu teoriju objektnih odnosa možemo usporediti s Lacanovim stadijem zrcala: „U individualnom emocionalnom razvoju preteča zrcala je majčino lice“ (Winnicott 2004, p. 139). Majčino je lice prvo zrcalo s kojim se dijete susreće, u majčinom se licu dijete ogleda i potvrđuje. Upravo je iz tog razloga iznimno važno majčino ponašanje u trenutku kada promatra vlastito dijete, odnosno kada dijete promatra nju: ,ako djetetovo

\footnotetext{
${ }^{16} \mathrm{Na}$ taj način prijelazan objekt i prijelazan prostor dobivaju ulogu obrambenih mehanizama od depresivnih i anksioznih stanja.
} 
viđenje sebe u majčinu licu nailazi na negativne karakteristike, to se može nepovoljno odraziti na razvoj sebstva“ (Durić 2013 p. 223).

Pomicanjem razvojnih faza psihičkog života unatrag, stavljajući težište na prededipsko razdoblje, koje ulogu muškarca, kao ključnog čimbenika ulaska u svijet normi i odricanja, u velikom dijelu umanjuje, postfrojdovska psihoanaliza objavljuje kako je upravo žena najzaslužnija za formiranje ličnosti, za razvoj seksualnih, individuacijskih te identifikacijskih procesa.

Na ovaj je način isključenost žene iz vjerojatno najutjecajnijeg psihičkog razvojnog procesa poništena. Trokutasta edipska struktura, unutar koje muškarac donosi znakove i zakone, zamijenjena je dijadnim prededipskim odnosom, a zrcalni su se stadij i formiranje ega s imena Oca preselili na lice Majke. 


\section{I. III. Egzistencijalistički feminizam}

Kada se 1949. godine pojavilo prvo izdanje Drugoga spola francuske filozofkinje Simone de Beauvoir, knjiga je istodobno izazvala skandal i odobravanje. Kroz egzistencijalističku prizmu autorica se bavi identitetom i drugošću žene predstavljajući je kroz više perspektiva: biološku, psihoanalitičku, marksističku. Temeljna misao Beauvoir sastoji se od činjenice da je ženska priroda samo društveni konstrukt i na toj misli vlastite će teze graditi znanstvenice iz područja rodnih studija, poput Judith Butler. U prvome dijelu knjige, obuhvaćajući biologijske podatke i psihofiziologiju ženskog spola, Beauvoir priznaje golem napredak koji je psihoanaliza ostvarila u odnosu na prethodnu konzervativnu struku: „Konkretno ne postoji tijelo-objekt koje su opisali znanstvenici, nego tijelo koje subjekt proživljava. Ženka je žena, u mjeri u kojoj se takvom osjeća [ ... ] Nije priroda ta koja definira ženu, nego ona samu sebe definira ponovno preuzimajući prirodu kroz afektivnost“" (Beauvoir 2016, p. 57). Međutim, autorica istodobno priznaje i postojanje brojnih dvosmislenosti koje psihoanaliza nije riješila. Prva od takvih nalazi se u samoj definiciji pojma seksualnost. Prema mišljenju Beauvoir ona, u psihoanalitičkoj teoriji, gotovo da koegzistira s egzistencijom: „s jedne strane kao da svaki avatar ljudskog bića ima spolno značenje, a s druge kao da svaki spolni fenomen ima egzistencijalni smisao“ (p. 58). No, ukoliko razdvojimo spolno od genitalnog, ističe Beauvoir, pojam spolnosti posve gubi na jasnoći. Autorica otvoreno zamjera Freudu činjenicu da je gotovo svaku našu misao interpretirao kao spolni fenomen, istovremeno svakom tom spolnom fenomenu dao je jedan viši egzistencijalni smisao. U tom smislu, psihoanalitičari promatraju čovjeka isključivo kroz prizmu spolne identifikacije, a odnos čovjeka s vlastitim tijelom i tijelima sličnih sebi, unutar nekog društva, temelj je svake psihoanalitičke terapije. No, Beauvoir odbija takvo viđenje ljudske osobnosti i tvrdi kako se svatko od nas u prvome redu zanima za okolinu koja ga okružuje, koju kroz vlastita iskustva i rad pokušava otkriti te $s$ kojom se pokušava uskladiti i spojiti, ne bi li pridonio općoj društvenoj dobrobiti i dobiti. Nema sumnje, ističe Beauvoir, da spolnost u ljudskom životu igra značajnu ulogu. Živo biće jednim dijelom jest i spolno tijelo, tako da uplitanje spolnosti u odnose pojedinca i drugih ljudskih bića ostaje neupitno. No, to svakako nije i ne može biti jedini i najvažniji aspekt ljudske egzistencije i ne može nam dati odgovore na sva pitanja, smatra Beauvoir (p. 63).

Najveću kritiku Freudovih tekstova koji obrađuju temu ženske seksualnosti Beauvoir upućuje u pogledu definicije libida, koji je, prema njezinom mišljenju, Freud obilježio kao 
suštinski mušku energiju ${ }^{17}$, te činjenici da, prema Freudovom mišljenju, većina ženskih frustracija proizlazi iz područja seksualnosti. Također, Beauvoir ne priznaje Freudovu tezu o ženskoj zavisti prema falusu, prema kojoj se žena osjeća poput „osakaćenog muškarca“, uviđajući da je drugačija i da joj nešto nedostaje. Ta ideja osakaćenosti, napominje Beauvoir, podrazumijeva uspoređivanje i vrednovanje, iz kojih proizlazi ženin prirodni submisivni položaj. Međutim, ako spolnost pokušamo uklopiti u cjelokupnu osobnost i još je pritom sagledati iz perspektive društva u cjelini, tada nam mnogo prihvatljivije mogu zvučati teze austrijskog psihoanalitičara Alfreda Adlera. Adler se, naime, u pogledu spolnosti i spolnog sazrijevanja žena s Freudom razilazi, ističući kako kompleks manje vrijednosti u žena nije izazvan nedostatkom falusa nego cjelokupnom društvenom situacijom. Prema njegovom mišljenju, djevojčica zavidi na falusu samo kao simbolu povlastica dodijeljenih dječacima; npr. mjesto koje zauzima otac u obitelji, sveopća prevaga muškaraca u svijetu rada, povlaštenost muškaraca u obrazovnom sustavu itd. Kada se djevojčica penje na stablo, ističe Adler, to nije zato da bi se izjednačila s dječacima, već zato što joj se penjanje najvjerojatnije sviđa. Također, Adler smatra kako slikanje, pisanje, bavljenje politikom i bilo kakvom drugom društvenom aktivnošću nije isključivo sublimacijski proces, kako to Freud tvrdi, već cilj vrijedan sam po sebi (p. 68). Beauvoir ističe kako ženskom biću ženskost i ženstvenost nisu urođene: ,žena po definiciji nije ženka, ona jedino u društvu, čija je članica, postaje žena. I tek tada postaje u potpunosti svjesna svoje ženskosti. Život, egzistencija, opstanak, ne podrazumijevaju vezu sa samim sobom, već vezu sa svijetom. Svatko od nas definira sebe tragajući za sobom po tom svijetu“ (p. 66). U poglavlju o psihoanalizi, Beauvoir zaključuje kako je ova nova znanost dala izuzetan doprinos u razumijevanju ljudskih bića, međutim, neke od njezinih metoda smatra potpuno pogrešnim, a uzimanje spolnosti kao datosti posve neprimjerenim.

Daljnja razmatranja ženskog položaja obilježena su istraživanjima o ženskoj podređenosti unutar vrste. Beauvoire ističe kako dvije biološki esencijalne crte obilježavaju ženu: njezin nezamjetan utjecaj na svijet i činjenicu da je uže podređena vrsti. Oduvijek je za ženu robovanje reprodukciji predstavljalo svojevrsni hendikep. Mjesečnica, trudnoće i porođaji umanjuju radnu sposobnost žene i tako umanjuju ženin osjećaj da se socijalno i psihološki ostvaruje: ,žena koja rađa tako ne poznaje oholost stvaranja; osjeća se kao pasivna igračka

\footnotetext{
${ }^{17}$ Prema Beauvoir, čak i kada govori o ženskom libidu, podrazumijeva ga kao ,složenu devijaciju libida općenito“ (Beauvoir 2016, p. 58).
} 
mračnih sila, a bolni je porođaj beskorisna ili čak nesnosna nezgoda [ ... ] No kako god, rađanje i dojenje nisu aktivnosti, nego prirodne funkcije. Nisu dio nekog projekta. Zato žena u njima ne nalazi motiv ponosite potvrde svoje egzistencije; pasivno podnosi svoju biološku sudbinu“ (p. 81). Osim umanjene radne sposobnosti, žene se od pamtivijeka suočavaju i s činjenicom da su, u većini slučajeva, isključene iz ratnih pohoda. Noseći oružje, riskirajući vlastiti život i često ubijajući druga živa bića, ljudski mužjak, na neki način, mijenja lice svijeta. Čovjek se ne uzdiže iznad životinje dajući novi život, nego riskirajući vlastiti, ističe Beauvoire (p. 82). Dok je žena prikovana za vlastito tijelo, za vlastiti čopor, muškarac vlada trenutkom i stvara buduću sliku svijeta, u kojoj žena tek pasivno sudjeluje. Iz svega navedenog, razvidno je da se muškarac, naspram žene, postavio kao gospodar. Gospodar koji od prvog dana svojeg postojanja na poklon dobija ženu. Ženu koja nije, poput njega, stvorena od božjeg materijala, već je izvučena iz muškarčevog rebra. Kao takva od samoga početka svijeta, u muškarcu nalazi izvor i cilj vlastitog postojanja. "Žena je muškarčev neesencijalni dodatak“ (p. 165), napominje autorica, ona je od samih početaka osuđena na igranje uloge Drugoga. Muškarci stvaraju bogove, a žene su tu da ih obožavaju. Društvena pravila, zakoni i običaji nametnuti su ženama kako bi se iste isključilo iz „ljudskog mitseina“, ističe Beauvoir (p. 166-167).

„Ženom se ne rađa. Ženom se postaje. Nikakva biološka, psihička, ekonomska kob ne definira oblik koji u društvu poprima ljudska ženka. Sveukupna civilizacija je ta koja oblikuje proizvod između mužjaka i kastrata koji se naziva ženom“ (p. 287), vjerojatno su najpoznatije rečenice kojima Beauvoir objašnjava teoriju ženskog i svega onog što definira "ženski karakter". Autorica ne negira činjenicu da postoji specifično ženski karakter, te u tvrdnjama poput ,žena je podlo pragmatična, nema smisao za istinu i točnost, manjka joj morala, koristoljubljiva je, voli proturječiti i sl.“ nalazi doista mnogo istine. Ono što, međutim, Beauvoir tvrdi jest da ova ponašanja i stavovi nisu fiziološki ili hormonalno uvjetovane činjenice, već su odraz ženinog položaja u društvu. Naime, žene unutar zajednice, kojom upravlja muški spol, zauzimaju podređeno mjesto. Da bi opstale, služe se vlastitom logikom i rješenjima jer stvarnost koju žena proživljava, daleka je od muškog načina rasuđivanja i pogleda na svijet. Sudbina žene poslušnost su i poštovanje. Njezino je tijelo posvećeno Mjesečevu ritmu, njezina je logika temeljena na strpljenju i pasivnosti: “dok čeka da se šećer otopi, da se tijesto digne i da se rublje osuši, žena osjeća snagu svoje pasivne erotike. 
U nedostatku osjećaja izravne djelotvornosti, ona bezbrižno prihvaća i najproturječniju

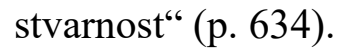

Iznimno veliku razliku između dva spola, u pogledu perceptivne i osjetilne dimenzije, Beauvoir naglašava kad je u pitanju riječ ljubav, smatrajući kako muškarac i žena ovu emociju različito shvaćaju, doživljavaju i proživljavaju. Za ženu je karakteristično, ističe Beauvoir, da se u ljubavnom odnosu potpuno predaje. Ona se svom muškarcu u potpunosti posvećuje, a odsutnost bilo kakvih uvjeta, takvu ljubav čini gotovo vjerom. S druge strane, dok žena pokušava apsolutno cijelu svoju egzistenciju podrediti gospodaru, zaljubljeni muškarac svim će se silama truditi ostati suveren i svoj. U svome ljubavniku svaka će žena sažeti ono što smatra esencijom muškarca. Svojim ponašanjem, svojom putenošću i submisivnošću žena će ponekad posve nesvjesno uzvisivati voljenog. Postaviti će ga kao vrhovnu vrijednost i stvarnost, a on će za nju postati bog pred kojim će se ona poništiti: „Služeći svom gospodaru, ona će se osjećati potpuna. Gledati će svijet njegovim očima, čitat će knjige koje on čita, voljet će ljude koje on voli, željet će udahnuti zrak koji je on već udahnuo [ ... ] Žena je, tako, drugo utjelovljenje voljenoga, njegov odraz, njegov dvojnik. Ona je On. Ona živi u njegovom svemiru“ (p. 689-690). Beauvoir napominje i kako psihoanalitičari često tvrde da žena u ljubavniku traži sliku svojega oca. No, otac ne zaokuplja svoju djevojčicu zato što je otac, već upravo jer je muškarac. Žena, naime, ne traži reinkarnaciju jednog muškarca u drugom, već želi ponovno doživjeti ono vrijeme kada se osjećala bezuvjetno voljenom i u potpunosti zaštićenom (p. 682).

U rujnu 1966. Godine Beauvoir i njezin životni partner Jean-Paul Sartre, pozvani su u Japan kako bi održali seriju predavanja iz područja feminizma i filozofije. Ona održava ukupno tri samostalna predavanja, na temu ženske umjetničke produkcije ${ }^{18}$. U toku predavanja dotiče se pomalo svih vidova umjetničke produkcije, no osobito naglašava odnos žena i književnog stvaralaštva. Razdvaja li i razlikuje ženska kreativnost rod od spola glavno je pitanje koje, u toku predavanja, zaokuplja Beauvoir. Analizu započinje teorijama o nastanku umjetničkih djela; što pokreće maštu i stvaralačke procese umjetnika, što motivira umjetničku ekspresiju. Beauvoir smatra kako svaku umjetničku produkciju uvjetuju iskustva (o čemu je već bilo govora u Drugom spolu), no postoji i tzv. proces autoregolamentacije (samoograničenja) ${ }^{19}$.

\footnotetext{
${ }^{18}$ Predavanja su sažeta i objavljena u knjizi Žena i kreativnost (2001).

${ }^{19}$ Beauvoir (2001, p. 34).
} 
Osim što mnoge umjetnice, spisateljice, nisu imale životna iskustva svojih muških kolega, te tako nisu mogle stvoriti ratne drame, političke traktate ili filozofske rasprave ${ }^{20}$, one već stoljećima prihvaćaju onakvu vrstu ekspresije koja prati njihov dnevni ritam i obaveze, služe se jezikom koji u najboljoj mjeri karakterizira njihovu svakodnevicu. Za zrelo pismo i umjetničko djelo visokointelektualnog sadržaja, ističe Beauvoir, potreban je, prije svega, osjećaj apsolutne slobode. Slobode u političkom, društvenom i doslovnom smislu vremena. Takva djela zahtijevaju izraženo i istančano kritičko promatranje: „Velika su djela ona koja preispituju smisao svijeta. No, žene to ne rade. Da bi dovele u pitanje smisao svijeta, morale bi se za taj svijet osjećati odgovornima. A tako se najčešće ne osjećaju“ (p. 33). Žene, tako, najčešće odabiru vrlo intimne žanrove, poput pisma, dnevnika, autobiografije i ljubavnog romana. ${ }^{21} \mathrm{U}$ njima će doći do izražaja sakupljena emotivna iskustva, ljubavni brodolomi, obiteljske drame i tome slično, a žene će im rado pribjegavati i zbog činjenice da su formalno manje zahtjevni. ${ }^{22}$

Iako privržena socijalizmu i marksističkoj teoriji, Beauvoir Drugi spol temelji na premisama Sartreove egzistencijalističke filozofije. Analizirajući ženu kao Drugo muškarca, Beauvoir ukazuje na „krađu“ ženskog identiteta i subjektiviteta, odnosno na prikaz žene kao imanencije te muškarca kao transcendencije. Prema njezinom mišljenju, takav prikaz muškarca i žene dominira svim aspektima društvenog, političkog i kulturnog života, a u velikoj mjeri i sama žena, mireći se s ulogom koju joj je prema biološkim pretpostavkama patrijarhat dodijelio, tome doprinosi.

\footnotetext{
${ }^{20} \mathrm{O}$ čemu je detaljno izlagala Virginija Woolf u knjizi Vlastita soba.

${ }^{21}$ Dugi niz godina žene su posezale za perom, ne bi li na taj način upoznale same sebe, otkrile ženski svijet vlastitim, ženskim, pogledom. Procesom pisanja, svojevrsne autoanalize, žene su dobile mogućnost drugačijeg doživljaja sebe. Kao odraz dugostoljetne izoliranosti i samoće, ženski jezik ukazao je na potrebu za razotkrivanjem. Taj novi jezik, pun osobnih pogleda, doživljaja i iskustava, njegovati će upravo spontane i intimne literarne oblike.

${ }^{22} \mathrm{U}$ odnosu na kazališnu dramu ili poeziju, roman, primjerice, ima mnogo jednostavniju strukturu, a može se prekinuti, mijenjati koncept te nastaviti u bilo kojem trenutku pisanja.
} 


\section{I. IV. Analitička psihologija}

Švicarski psihijatar Carl Gustav Jung, izašavši iz okvira tradicionalne medicine, stvorio je potpuno novu psihoterapijsku znanost - analitičku psihologiju, često nazivanom i dubinska psihoanaliza, te doveo u pitanje Freudovu teoriju spolnosti ${ }^{23}$. U toku svojih prvih istraživanja Jung se uvelike oslanjao na već poznate i priznate Freudove teze o svjesnom i nesvjesnom, o libidnoj energiji i kulturnom potiskivanju. No, s vremenom razvija vlastitu teoriju o mapiranju ljudske psihe, kao i vlastitu teoriju libida, tako da se 1912. godine njih dvojica potpuno razilaze $^{24}$.

U pogledu kulturne represije i nastanka neurotskih poremećaja, Jung je s Freudom bio suglasan. Prema njegovom se mišljenju kulturni procesi sastoje od progresivnog sputavanja animalnog u čovjeku: „To je proces domestifikacije koji se ne sprovodi bez pobune od strane slobodoljubive životinjske prirode [...] Neurotičar je samo poseban slučaj čovjeka neusuglašenog sa samim sobom, koji u sebi mora sjediniti prirodu i kulturu“ (Jung 1977a, p. 18). Čovjekova se nagonska priroda, ističe Jung, konstantno sudara s kulturnim ograničenjima i upravo je u tom smislu sama psihoanaliza pronašla vlastite korijene. Borba svjesnog i nesvjesnog, kulture i prirode, usmjeravanje libidne energije i snage vlastitih instinkta nastavljaju se razvijati kao krucijalne teme njegovih istraživanja. Jungovo je viđenje ljudske psihe, njezine iskonske snage i dubine, njezinih potencijalno beskonačnih mogućnosti preobražaja uistinu jedinstveno ${ }^{25}$. Prema njegovom mišljenju, ljudska se psiha održava stabilnom balansirajući konstantno između dvije potpuno nesvjesne želje: želje za cijepanjem

\footnotetext{
${ }^{23}$ Uključivši u psihijatriju i druga područja, poput religije, filozofije, teozofije, antropologije, književnosti, te mijenjajući stavove o genetski uvjetovanim psihozama, poput shizofrenije, odvojio je psihoterapiju od neuroznanosti, anticipirajući antipsihijatrijski pokret. Svojom snažnom intuitivnom sposobnošću predvidio je mnoge nadolazeće teme i problematike kasnog 20. i ranog 21. stoljeća, poput nacionalizma, kulturoloških i ideoloških sukoba, te rasprava o spolnom, rodnom i rasnom identitetu (Samuels 1985, p. 2).

24 Freudovo i Jungovo druženje započinje 1906. godine, kada je tada pedesetjednogodišnji Freud u psihijatrijskim krugovima već bio poznat po dvjema vrlo intrigantnim knjigama o snovima (Tumačenje snova/Die Traumdeutung, 1900.) i seksualnosti (Tri rasprave o teoriji seksualnosti/Drei Abhandlungen zur sexual Theorie, 1905.), studijama o histeriji, tj. čuveni slučaj Dora (1905.) i njegovim tezama o utjecaju seksualnosti na nastanak neurotskih poremećaja. Dvadeset godina mlađi Jung, koji je u to vrijeme pokazivao izniman talent za psihijatriju i njezinu znanstveno-istraživačku djelatnost, u to prijateljstvo ulazi fasciniran Freudom i njegovim radom. No, iako je do prvih nesuglasica došlo već u ljeto 1906., objavljivanjem Jungove knjige Psihologija Dementie praecox (Über die Psychologie der Dementia praecox), do potpunog razilaženja dolazi 1912. godine, nakon Jungovog objavljivanja knjige Preobražaji i simboli libida, kojom se Freudova teorija seksualnosti dovodi u pitanje, odnosno teze o seksualnim nagonima kao nagonima destrukcije Jung zamjenjuje tezom o pozitivnim seksualnim nagonima preobražaja.
}

25 “Jung je vjerovao da naša psiha posjeduje sposobnost uočavanja štetnog i korisnog, sposobnost samoregulacije, čak i samoozdravljenja“" (Samuels 1985, p. 5). 
i želje za utjelovljenjem, a upravo se putem tog samoregulativnog sustava, iz prostora sukoba, dolazi do prostora razvoja, odnosno do ostvarenja vlastite cjelovitosti, koju Jung označava terminom Sebstvo. Sebstvo je ključan termin analitičke psihologije, a označava najvišu razinu ljudskog potencijala. Ono je finalni cilj kojem svaka ljudska jedinka teži, prostor unutar kojeg se, na temelju naših razlikovnih odnosa $\mathrm{i}$ iskustva s okolinom, nastojimo razviti. Do cjelovitosti sebstva, prema Jungovom se mišljenju, dolazi procesom individuacije, sazrijevanjem i pomirbom unutarnjih konflikata psihe, u cilju ostvarivanja cjelovite ličnosti u svim njezinim aspektima: „Individuacija znači postati pojedinačno biće, i ukoliko pod individualnošću podrazumijevamo našu najintimniju, posljednju i neusporedivu jedinstvenost, postati svoja Sopstvenost (Selbst). Zbog toga bi se individuacija mogla prevesti i kao samoostvarenje ili kao samoispunjenje“(Jung, 1977d, p. 189).

Za kvalitetnije razumijevanje procesa individuacije nužno je poznavati Jungovu teoriju $o$ raščlambi ličnosti, kao i teoriju nesvjesnog. Prema Freudovom se mišljenju sadržaji nesvjesnog ograničavaju na infantilne tendencije koje se, upravo radi svog inkompatibilnog karaktera, potiskuju. Potiskivanje je proces koji se uspostavlja u ranom djetinjstvu, uslijed moralnog utjecaja okoline, a zadržava se tokom cijelog života. Pomoću analize ta se potiskivanja dovode do svijesti, oslobađajući naše nesvjesno. U tom smislu, Freudova teorija podrazumijeva nesvjesno kao prostor potisnutih osobnih sadržaja, koji su u bilo kojem trenutku mogli biti dio svjesne razine, no pod utjecajem okoline, kulture i okolnosti, potisnute su u prostor nesvjesnog. Jung se s takvom teorijom ne slaže. Za njega nesvjesno posjeduje i onu drugu stranu: „U njegovom području ne nalaze se samo potisnuti sadržaji, već i sav onaj psihički materijal koji nije dostigao pragovnu vrijednost svijesti. Nemoguće je sav taj materijal objasniti principom potiskivanja, inače bi uklanjanjem potiskivanja čovjek morao dobiti apsolutno pamćenje, koje više ništa ne zaboravlja. Osim potisnutog materijala, u nesvjesnom se nalazi i sve ono podpragovno, uključujući i sublimalne čulne opažaje“ (Jung 1977c, p. 137-138). Dok je za Freuda područje nesvjesnog obilježeno negativnim predznakom, predstavljajući neku vrstu „mentalne kante za nepoželjan otpad“, za Junga ono je beskrajno vrelo ljudske kreativnosti, temelj naše psihičke strukture. Prema mišljenju Junga, ono drži na okupu sve funkcije i razine naše ličnosti, brine o očuvanju integriteta ${ }^{26}$, kompenzira i topi nepoželjne naslagane slojeve, oslobađajući svijest od egoističnog klupka

\footnotetext{
${ }^{26}$ Očuvanje od cijepanja ličnosti.
} 
naših želja, ambicija i strahova, koje nesvjesno prima. Na taj način, ističe Jung, nastaje svijest koja nije više sputana, krhka i osjetljiva (Jung 1977c, p. 139-149).

Jung je nesvjesno rasporedio u dva sloja: lično nesvjesno (das persönliches Unbewusstes) $i$ kolektivno nesvjesno (das kollektive Unbewusste ${ }^{27}$. Lično nesvjesno sadrži naša osobna iskustva i dotiče se naše osobne prošlosti, stvarajući inventar onog materijala koji naša osobna svijest nije još prihvatila: „Lično nesvjesno sadrži izgubljena sjećanja, potisnute ili namjerno zaboravljene neugodne predstave, tzv. podpragovna sublimalna opažanja, čulne percepcije koje nisu bile dovoljno jake da dopru do svijesti, i konačno sadržaje koji još nisu sazrijeli za svjesnost“ (Jung 1977b, p. 70). S druge strane, kolektivno nesvjesno za Junga predstavlja dublji sloj nesvjesnog. Ono nosi teret psihičkog života naših predaka, taloge njihovih kolektivnih iskustava, ustaljenih kroz niz godina i generacija. Kolektivno nesvjesno pretpostavka je i osnova svih naših psihičkih zbivanja, točka u kojoj se psihijatrija suočava s antropološkim osnovama: „U svakom pojedincu, osim ličnih reminiscencija, postoje velike iskonske slike, $\mathrm{tj}$. naslijeđene mogućnosti čovjekovog predstavljanja, onako kako je oduvijek bilo. Činjenica ovog nasljeđa objašnjava zapravo čudnovati fenomen da se izvjesni materijal i motivi sage ponavljaju u identičnom obliku na cijeloj zemlji [ ... ] Radi se o manifestacijama dubljih slojeva nesvjesnog, gdje spavaju općeljudske iskonske slike, označene kao arhetipovi“ (Jung 1977b, p. 69-70).

Jungova raščlamba ličnosti i teorija spolova dodatno su ga udaljile od Freuda. On psihičku strukturu vidi kao piramidu na čijem se vrhu nalazi persona. Persona topički odgovara Freudovom Nad-Ja (Super-Ego), te predstavlja sustav odnosa između individualne svijesti i zajednice. Ona nas štiti od ogoljavanja ličnosti i svih nepoželjnih utjecaja koji bi mogli doprijeti do ega i naštetiti mu. Persona je naša „zaštitna folija“, bez nje smo ranjivi i izloženi. Ona je maska kojom prikrivamo našu stvarnu prirodu i prikazujemo sebe na okolini prihvatljiviji način jer: ,zajednica očekuje, odnosno mora očekivati od svake individue da po mogućnosti što potpunije igra njoj dodijeljenu ulogu“ (Jung 1977f, p. 210). Druženje s ostalim ljudskim bićima, kontakt $\mathrm{s}$ našom okolinom, podrazumijeva kontakte ovih površinskih obrazina ljudske duše nazvane persona. No, već je sljedeći sloj psihičke strukture, ističe Jung, teško dostupan. Taj sloj Jung označava kao ego i na prvi pogled ne razlikuje se mnogo od Freudove definicije ega. On i dalje ostaje na granici svjesnog i nesvjesnog,

\footnotetext{
${ }^{27}$ Termin na kojem počiva gotovo cijela Jungova doktrina.
} 
preuzimajući ulogu medijatora, no za Junga predstavlja i najkritičniji dio strukture naše ličnosti, mjesto najsuptilnijih kompenzatornih mehanizama, mjesto projekcije i individuacije $\mathrm{e}^{28}$. Braneći se od eventualno štetnih i negativnih slika o sebi, ego naše vlastite emocije usmjerava na bića iz okoline. Da bi se takav mehanizam uspješno pokrenuo nužno je da naše nesvjesno prethodno obavijesti ego o nemogućnosti zadržavanja prekomjerne količine potisnutog materijala. Akumulacija sve veće količine negativne energije stvorit će velik pritisak na ego, a on će, u svom prvotnom nastojanju da kompenzira sve naše nepoželjne emocije, započeti projicirati. Taj trenutak, trenutak projekcije, burna je reakcija naših nesvjesnih dijelova koji se, u tom trenutku, pokušavaju probiti do svjesnih razina, ne bi li olakšali napetost ega (Jung, 2008).

Nepoželjan materijal koji ego odbaci nakuplja se u prostoru koji Jung definira kao sjenka. Ona, topički promatrano, odgovara Freudovom Idu, mjestu najdublje potisnutih sadržaja te, noseći negativan predznak, označava sve one nepočudne i nedolične sadržaje nesvjesnog, našu animalnu stranu prirode. Sjenka, ističe Jung, posjeduje izuzetnu snagu, koju crpi direktno iz ega. Sve ono što ego kompenzira i poriče, sjenka će nastojati razviti. U tom smislu, ona je izravna „prijetnja“ egu, ona konstantno izaziva naše kulturno nasljeđe, naše moralne i etičke stavove, naše pozitivne ambicije. Sjenka je u direktnom sukobu s personom, mjestom „velikih očekivanja“, a proces individuacije, proces ostvarivanja cjelovitosti ličnosti u svim njezinim aspektima, označava upravo taj sukob koji se, primjećuje Jung, odvija bez znanja i pristanka (Jung 1977d, p. 190). U konačnici, ukoliko ego izdrži taj pritisak, proces individuacije dovesti će do oslobađanja od sjenke i njezine pomirbe s personom. U tom trenutku osvijestit će se i stopiti svi elementi, funkcije i tipovi naše ličnosti: naše introvertno i ekstrovertno, naše mišljenje, osjećaji, intuicija i osjetilna percepcija. Dakle, iako negativnog predznaka, sjenka odigrava vrlo važnu ulogu u prepoznavanju i pozitivnoj integraciji vlastitih unutarnjih konflikata, koji nas usmjeravaju ka cjelovitosti.

No, je li nesvjesno u muškaraca i žena strukturirano na jednak način, pitanje je koje dugi niz godina zaokuplja Junga, a odgovor koji slijedi, nakon niza istraživanja, koja su, osim medicine, uključivala istočnjačku filozofiju, religiju te antropologiju, najcjelovitije je sažet u teoriji o animusu $i$ animi $^{29}$. Prema Jungovom mišljenju, muškarac i žena imaju različito

\footnotetext{
${ }^{28}$ Oba vrlo arhaična primarna obrambena mehanizma.

${ }^{29}$ U O psihologiji nesvjesnog, odabrana djela C.G.Junga, knjiga druga (1971).
} 
strukturirano nesvjesno. U prostoru nesvjesnog svakog muškarca postoji naslijeđena slika žene, pomoću koje on shvaća ženska bića iz okoline ${ }^{30}$ i upravo je ona važan izvor ženstvenosti muške duše, ističe Jung. Suprotno tome, ženino nesvjesno posjeduje urođenu sliku muškarca ${ }^{31}$, tzv. arhetip muškarca. Dok anima dodjeljuje muškom karakteru jednu erotsko-emotivnu dimenziju ${ }^{32}$, animus će kod žene ojačati njezinu sposobnost logičkog zaključivanja i donošenja razumskih odluka bez tereta emocija (Jung, 1977f, p. 206-208). U eseju Ja i moja anima $^{33}$, američki psihijatar Elio Frattaroli objašnjava kako u svakom odnosu, između muškarca i žene, muškarac nesvjesno projicira dijelove vlastite anime, poput slike (imaga), u ženu. Istovremeno, realna se slika te iste žene prikazuje muškarcu isključivo u onim dijelovima koji su razumljivi njegovom nesvjesnom prototipu anime. Muškarac se tako istovremeno zbližava sa ženom nasuprot sebi, odnosno sa ženom unutar sebe. Taj dijalektički proces unutarnjih konflikata među spolovima nužan je za potpunu integraciju i samoostvarenje, ističe Frattaroli (2008, p. 172-173).

Jung žensku psihologiju smatra drugačijom od psihologije muškarca, no nipošto je ne vidi inferiornijom, kao ni ekskluzivnijom: „ženama se ne može eo ipso pripisati inferiorna svijest, ona je samo drugačija nego što je muška svijest. No, kao što je žena jasno svjesna stvari koje muškarac još pipa u mraku, tako ima, shodno prirodi stvari, iskustvenih područja kod muškarca koja kod žena još leže u sjenci neizdiferenciranosti, uglavnom stvari za koje se žena, prije svega, slabo interesira“ (Jung 1977f, p. 225). Jung ističe kako je u svakom muškarcu prisutna i ženska strana njegovog nesvjesnog, koja mu često služi kao izvor informacija o stvarima koje on slabije ili nikako ne vidi. Ona mu omogućuje da, putem intuicije, naslućuje i prepoznaje situacije koje njegova „muška strana“, vođena rigidnom logikom, propušta. Prema Jungovom je mišljenju ženska intucija mnogo superiornija od muške i predstavlja se kao dominatno ženska karakteristika koja muškarcu, u datom trenutku, može poslužiti kao korisno upozorenje (1977f, p. 225). Osim intuicije, veliku ulogu u psihičkom životu žene igraju i lične veze: „široko područje trgovine, politike, tehnike i nauke, čitavo carstvo primijenjenog muškog duha, kod žene pada u sjenku svijesti, nasuprot tome

\footnotetext{
${ }^{30}$ Sliku koju Jung naziva anima.

${ }^{31}$ Animus.

${ }^{32}$ Ono što muškarci misle da znaju o ženskoj erotici i osjećajnom životu žene, počiva na projekciji njihove vlastite anime (Jung 2008, p. 184).

${ }^{33}$ Frattaroli, E. (2008) Me and my anima: through the dark glass of the Jungian/Freud interface.
} 
ona razvija dalekosežnu svjesnost ličnih veza, čije beskrajno nijansiranje po pravilu izmiče muškarcu“ (1977f, p. 225). Upravo je iz svega navedenog poželjno da postoji struktura koja, na neki način, balansira između dva suprotna pola - Jina i Janga, Sunca i Mjeseca. Anima će muškarca unijeti u osjetilnu, emotivnu dimenziju, učiniti ga ranjivim, jer: ,anima rađa ćudi koje izbijaju iz tamnih pozadina“" (1977f, p. 226), dok će animus stvoriti pretpostavke i razmišljanja, držeći se čvrstih i neoborivih stavova, principa i uvjerenja, koja neće biti tako lako dovesti u pitanje: ,animus predstavlja skup autoriteta, koji ex cathedra donose nepobitne sudove [ ... ] kod intelektualnih žena, animus daje povoda intelektualnom“ (1977f, p. 226). Dok je anima nježna, intuitivna i empatična, animus je razuman, logičan i samouvjeren. Kako je za svrhu induviduacije, tzv. samoostvarenja, neophodno da čovjek zna napraviti razliku između onoga kako izgleda sebi a kako drugima, tako je za tu istu svrhu potrebno da postane svjestan svog nevidljivog sustava odnosa prema animi, odnosno animusu, kako bi se od njih mogao diferencirati. Ukoliko to ne učinimo, nagomilavanje zahtjeva našeg nesvjesnog dovest će do projekcije, a moguće i do neurotskih poremećaja (1977f, 213).

Teorija o animi i animusu poslužila je kao polazišna točka u shvaćanju i definiranju pojmova poput biseksualnosti, kontraseksualnosti, homoseksualnosti, roda i spola, a na suvremenu psihologijsku znanost primijenila ju je američka post-jungovka Polly YoungEisendrath. U knjizi Subject to Change: Jung, Gender, and Subjectivity in Psychoanalysis (2004) Eisendrath se osvrće na činjenicu kako su sve do Junga teorije o spolu bile androcentrične, kako su uglavnom slijedile Freudovo načelo o ženama kao jedinkama koje zavide muškarcu na organu simbolu spolne moći. No, s Jungom, ističe Eisendrath, takvo se viđenje žene mijenja. On dokazuje da u svakom muškarcu postoji žena, odnosno u svakoj ženi postoji muškarac, a ponekad su te prisutnosti i zapanjujuće velike, jer kako je Jung istakao: „nijedan muškarac nije tako sasvim muški da u sebi ne bi imao ničega ženskog, i obrnuto“ (Jung 1977f, p. 206). Drugu stranu naše osobnosti Eisendrath imenuje kao podosobnost (subpersonality) i objašnjava kako ona vodi vlastiti život, potpuno neovisna od ostatka naše ličnosti. Ta autonomna sila suprotnog spola u nama u teoriji roda poznata je pod imenom kontraseksualnost (contrasexuality) ${ }^{34}$ i predstavlja vrlo moćan psihički mehanizam koji, nalazeći se u najužoj vezi s egom, konstantno balansira i regulira. O njegovoj sposobnosti medijacije i regulacije ovisiti će kvaliteta samog ega.

\footnotetext{
${ }^{34}$ Označavajući kontraseksualni feminizirani kompleks u muškarca, odnosno, kontraseksualni maskulinizirani kompleks u žene.
} 
Jungov doprinos suvremenim feminističkim istraživanjima iznimno je velik. Odmaknuvši se od Freuda i psihoanalize koja je dugi niz godina bila usmjerena na važnost oca i edipsko pitanje, ne uzimajući mnogo u obzir razdoblje prije četvrte godine djetetova odrastanja, Jung se samouvjereno usredotočio na pitanje odnosa majka-dijete, odnosno na vrlo rani stadij djetetova razvoja, uključujući i neka prenatalna istraživanja. Snaga ženske empatije i intucije, važnost majke i njezine spone s djetetom, koncept muškarca u ženi i žene u muškarcu, rod iznad spola pojmovi su kojima se Jung odmakao od tadašnje tradicionalne psihijatrije i stvorio znanstvene temelje za buduća psihoanalitička feministička istraživanja. 


\section{II. S FEMINIZMA NA NEOFEMINIZAM}

\section{II. I. Kontrakulturni preokret}

Šezdesetih su se godina europske države i države američkog kontinenta mnogo više međusobno razlikovale nego danas. Globalizacijski su procesi bili tek u povojima, a mediji nisu posjedovali takvu neovisnost i utjecajnost kakvu danas prepoznajemo. Ipak, zahvaljujući prvim iskustvima dnevnih izvještaja s mjesta događaja, ljudi postaju svjesni važnosti i utjecaja događaja na drugom kraju svijeta. Komunikacijski sateliti i novi mediji omogućili su čovjeku draž neposrednog iskustva i učinili svijet „globalnim selom“335. U ovom turbulentnom razdoblju, širom svijeta, gotovo istovremeno, došlo je do spontane eksplozije manjih i većih revolucionarnih pokreta i pobuna. U različitim su se zemljama ljudi bunili protiv različitih stvari, gdje je bilo komunizma, ljudi su ustajali protiv komunizma, gdje je vladao kapitalistički poredak, ljudi su ustajali protiv njega (Kurlansky, 2007).

Općenito govoreći, šezdesete i sedamdesete godine snažno su obilježene radikalnim pokretima za ljudska i građanska prava, masovnim studentskim pobunama protiv autoritarnosti svih oblika, te željom za prestankom američke intervencije u Vijetnamu. Zajednička poveznica svih ovih međusobno različitih događaja jest pobuna mlade generacije, a ta se pobuna, poglavito $u$ retoričkom smislu, bitno razlikovala $u$ SAD-u, $u$ čijem je političkom spektru ljevica bila slabije zastupljena, te time i slabije utjecajna, od Europe, gdje su lijeve struje poprimile uistinu široke razmjere. $\operatorname{Roszak}^{36}$ (1978) ističe kako je američka omladina veći dio kontrakulturne revolucije posvetila otporu prema tehnokratskom napretku i mehanizaciji društva, a manje klasnim borbama i rastu teškog siromaštva. Američko postindustrijsko društvo šezdesetih je godina doseglo vrhunac vlastite integracije i homogenizacije. Gotovo svi aspekti ljudske egzistencije postali su podložni modernizaciji, racionalizaciji i planiranju, stvarajući „takvu organizaciju društva koja se po preciznosti može mjeriti s mehanizmom“ (p.16).

\footnotetext{
${ }^{35}$ Ovim su terminom najavljeni budući globalizacijski procesi, rast vizualnih tehnologija, mehanizacije i robotizacije, kao i promjene čovjekove percepcije i njegove uloge u svijetu u kojem individualni identitet ustupa mjesto kolektivnom identitetu (McLuhan, 1992).

${ }^{36}$ Roszak navodi dva glavna toka studentskih pokreta. Prvi je onaj politički i obilježen je snažnim istupanjem nove ljevice na političku scenu, a drugi je onaj kontrakulturni, koji podrazumijeva način života malog dijela omladine koja se radikalno, sve do samoisključenja, suprotstavlja dominantnoj kulturi odraslih (Roszak 1978, p. 30-31).
} 
U ovoj eri „socijalnog inženjeringa“ (p.16) svi aspekti društva, od politike do obrazovanja, od prirode do kulture, postaju predmetom tehničkog ispitivanja i manipulacije, što stvara uvjete za krizu građanskog svijeta ili, kako je Erich Fromm naziva, „suvremenu ljudsku krizu“ (Fromm 1977, p. 13). Nakon što je čovjek, zahvaljujući vlastitom razumu i vještinama kojima raspolaže, stvorio sve materijalne preduvjete potrebne za rast i razvoj društva, dosegnuvši vrhunac, počeo se osjećati usamljeno i tjeskobno, gubeći istovremeno iz vida „cilj koji svemu tome daje konačno značenje - čovjeka“ (p.14).

Poraz čovjeka i njegovih dostignuća osnovna je teza kontrakulturnog pokreta koji, osim ekonomskih i političkih implikacija, sadrži i one psihološke: ,interes za jedan novi moral, za životnu sredinu dostojnu čovjeka, za potpunu emancipaciju čula, za oslobođenje čula od prinude da se ljudi i stvari smatraju predmetima trgovačkih odnosa“ (Marcuse 1977, p. 1-2). Oslobođenje od represije i povratak u prvobitno stanje, u kojem pozitivna stvaralačka energija dolazi do svog izražajnog maksimuma, cilj je kontrakulturnog pokreta mladih, a sadržan je u paroli ,,seksualno oslobođenje ${ }^{637}$.

Seksualno oslobođenje, kao novo stanje uma, inzistira, prije svega, na promjeni načina komunikacije. Kako jezik ima najveću ulogu u oblikovanju svijesti i vrijednosnih sudova, novo doba nastoji oformiti ,jezik ljubavi“ - jezik u potpunosti lišen posvojnih zamjenica ${ }^{38}$, kao i vrijednosnih sudova i stavova o drugima. Oslobođeni um, vođen jezikom ljubavi, spreman je prihvatiti ljude kakvi jesu i spreman je voditi život ispunjen pozitivnom stvaralačkom energijom: „suština svjetske revolucije šezdesetih bila je želja za stvaranjem čovjeku primjerenog svijeta, čovjeku primjerenog društva, čovjeku primjerenog načina življenja“" (p. 363).

Šezdesete su godine snažno obilježene i pitanjem nacionalnog identiteta te nacionalne i ekonomske neovisnosti. Završena je kubanska revolucija ${ }^{39}$, a njezin je ishod doveo do burne reakcije SAD-a i do konačne eskalacije hladnoga rata. 1965. pogubljen je marksistički

\footnotetext{
37 Jim Haynes objašnjava kako, u naravi, taj termin označava trostruko oslobođenje: oslobođenje od represije nad samim sobom, oslobođenje od navike provođenja represije nad drugim ljudima, te prepoznavanje i oslobođenje od represije nametnute od drugih. Prema njegovom su mišljenju upravo ovo tri osnovna načela koja dovode, u konačnici, do potpunog seksualnog oslobođenja (Haynes 2000, p. 361).

${ }^{38}$ Iako svi pripadaju svima nitko ne posjeduje nikoga, osim (možda) samoga sebe (p. 361).

${ }^{39}$ Građanski rat koji se od 1953. do 1959. vodio između režima proameričkog predsjednika Batiste i ljevičarskih nacionalističkih pobunjenika, koje je vodio Fidel Castro. Nakon pobjede Castrovih gerilaca, Kuba postaje prva socijalistička, odnosno komunistička država na zapadnoj hemisferi.
} 
revolucionar Ernesto Che Guevara, što unosi dodatan revolt i pojačava sukobe unutar i između država. Političku scenu uzburkava i izraelsko-palestinsko pitanje. Iako se 1967. diplomatskim putevima pokušalo iznaći rješenje, koje bi zadovoljilo obje strane, 1968. Izrael otvara novi sukob, a Palestinska oslobodilačka fronta, pod vodstvom Yassera Arafata, započinje niz organiziranih terorističkih napada diljem svijeta.

U tako izuzetno konfliktnoj klimi, obilježenoj snažnim antikomformizmom ${ }^{40}$, pojavljuje se i pitanje vijetnamskog sukoba, koje je obilježilo mandate čak trojice američkih predsjednika: Kennedyja, koji je slanjem američkih vojnih savjetnika sve i započeo, Johnsona, u čije je vrijeme rat eskalirao, te Nixona, koji je izbornu pobjedu ostvario obećanjima o povlačenju američkih trupa iz indokineskog područja.

Cilj ovog rata bilo je nacionalno i socijalno oslobođenje, a američka je intervencija jednako prijetila opstanku vijetnamskog naroda, kao i životnim interesima stanovništva SAD-a i njihovih saveznika. Sukob kolosalnih razmjera štetno je utjecao na američko gospodarstvo, a radi zaustavljanja sve veće zaduženosti države, Johnson je zatražio i veliko povećanje poreza građanima $^{41}$. Troškovi vijetnamskog rata zaustavili su i mnoge znanstvene projekte, poput onih vezanih uz istraživanje svemira, a ministarstvo obrane imalo je samo jedan cilj: Vijetnam. Iz tog, ali i nekih drugih razloga, poput sve većeg zajedništva naroda Sjevernog i Južnog Vijetnama, te njihove želje da se samostalno izbore za vlastitu neovisnost, rastao je broj onih Europljana i Amerikanaca koji su željeli prekid vojne intervencije Zapada.

Posluživši kao koagulacijska točka novih, međusobno različitih, ideoloških tendencija, vijetnamsko je pitanje snažno ojačalo razinu međunarodne suradnje. Pacifisti, novi i stari ljevičari, borci za građanska prava, studenti i mladi intelektualci pokrenuli su niz mirnih prosvjeda diljem planeta. Najbrojniji među njima bili su prosvjedi u Washingtonu i San Franciscu, te onaj najzapamćeniji u ožujku 1967., koji je poveo Martin Luther King, krenuvši od njujorškog Central Parka do zgrade Ujedinjenih Naroda. Deset mjeseci kasnije, 01.01.1968., usprkos važnoj objavi Ujedinjenih Naroda o Međunarodnoj godini ljudskih prava te njihovom pozivu na prekid rata u Vijetnamu, sukobi se nastavljaju sve do konca

\footnotetext{
${ }^{40}$ Kurlansky ističe šezdesete kao najznačajnije godine za žene i to ,ne zbog duljine suknje, nego zbog, primjerice, činjenice da je Muriel Siebert 1. siječnja 1968. objavila da je prva žena koja u 175 godina povijesti te ustanove ima pravo trgovati dionicama na njujorškoj burzi““ (p. 24).

41 Amerikanci su zapravo oduvijek sudjelovali u vijetnamskom sukobu, financirajući čak i do četiri petine troškova francuskog ratovanja do 1954. (p. 10).
} 
1974., odnosno do početka 1975., kada se Sjeverni i Južni Vijetnam ujedinjuju u jednu državu. Posljedice Vijetnama dovele su u pitanje, više nego ikad, funkcioniranje američkog državnog sustava, tako da je, nakon brojnih nereda i nemira, pokrenut čitav niz reformi na području ljudskih i građanskih prava, a poslijeratni društveni kaos rezultirao je i sve većim utjecajem feminizma, tj. počecima njegove institucionalizacije i akademizacije. 


\section{II. II. Womens'Lib}

Ključni trenutak preokreta $\mathrm{s}$ feminizma kakav je postojao do šezdesetih godina na novi feminizam koji će uslijediti nakon tog razdoblja započinje buđenjem Pokreta za oslobođenje žena (Women's Lib). Pokret je proizašao iz raznorodnih gibanja s početka šezdesetih godina, te uklopivši se potpuno u njih zahvatio je međusobno veoma različite skupine, klase i stranke. U povijesnom pregledu raznih lijevih struja šezdesetih i sedamdesetih, Massimo Teodori navodi tri ključna izvorišta ovog pokreta. Prvi je onaj koji se razvio u okviru Nove ljevice (New Left) u Sjedinjenim Američkim Državama, započinje godine 1963. antirasističkim maršom pod vodstvom Martina Luthera Kinga, razvija se kroz cijele šezdesete, a maksimalnu snagu doseže 1968. unutar studentskih pobuna. Drugi kao uporište ima London i obilježen je psihološko-kulturno-političkim utjecajem i poznatim kongresom Dijalektika oslobođenja, uz sudjelovanje Coopera, Lainga i Marcusea ${ }^{42}$, a treći se izvor sastoji od više manjih skupina radničkog pokreta, koji se bore za jednake plaće žena i muškaraca, odnosno za iste mogućnosti školovanja i općih uvjeta u svijetu rada (Teodori 1979, p. 357).

Temeljna pitanja pokreta Women's Lib, koji se s prostora SAD-a i Engleske vrtoglavom brzinom proširio na cijelu Zapadnu Europu, tiču se problematike opresije patrijarhalnoga sustava i inferiornog položaja žena, problematike političke i moralne nekorektnosti, odnosa prema ženi u poslovnom i obiteljskom okruženju, te ženin pasivan i subordiniran položaj unutar bračne zajednice. Ono što zaokuplja i pokreće feministice ovog novog razdoblja teme su koje ukazuju na postojanje nevidljivih razlika, tzv. staklenih stropova, temeljenih na nizu raznih spolnih, odnosno rodnih predrasuda. Krenuvši od analiza sfere seksualnosti i revidiranja Freudovih teorija o spolnom sazrijevanju, nekoliko tisuća pripadnika ovog novog pokreta zalaže se za poništavanje bioloških razlika i stvaranje novog društva u kojem će svatko, bez obzira na spol, uživati jednake pogodnosti: „,nema urođenih osobina po kojima bi se ljudska bića razlikovala, razlike su nametnute obrazovanjem i društvom“ (p. 358).

\footnotetext{
${ }^{42}$ Herbert Marcuse bio je frojdovski marksist koji je, uz Normana Browna, zaslužan za rehabilitaciju teorije erosa. Nadovezujući se na Freudovo djelo Nelagoda u kulturi (1929), u kojem Freud razmatra čovjeka kao prirodno autodestruktivno biće vođeno energijom Thanatosa, Brown, u knjizi Život protiv smrti (1959), i Marcuse, u Čovjek jedne dimenzije (1964) te Eros i civilizacija (1965), razmatraju ljudsko tijelo kao medij pomoću kojeg će se nagonski čovjek potpuno osloboditi. Odlučno osuđujući sve oblike političke i kulturne hegemonije, jezičnog i obrazovnog totalitarizma, Marcuse je utjecao na struje kontrakulturnog pokreta 60-ih i 70-ih. Pobijajući Freudove teze o sublimaciji nagona te povijesno i društveno relativizirajući procese potiskivanja, Marcuse iznosi tezu o tzv. nerepresivnoj civilizaciji unutar koje se sve ono kapitalističko i konzumerističko pretjerano proizvođenje potpuno poništava, a bitno postaje ono esencijalno, nužno za opstanak.
} 
Ovaj novi feminizam imao je antibirokratsko, neinstitucionalizirano i neformalno obilježje, a obzirom da nije bio ni ideološki ni klasno obojen, privukao je mnoštvo žena različite dobi, imovinskog i materijalnog statusa. No, Teodori ističe kako nisu sve struje ovog pokreta dijelile jednaka načela i programe. Jedni su smatrali da, žensko razumijevanje može doći samo od ženskih analiza“ (p. 362), drugi su smatrali da oslobođenje žena može biti samo dio općeg procesa emancipacije čovječanstva, odnosno da se problemi kapitalističkog društva koje izrabljuje i ljude smatra dobrima ne tiču samo žena, već i muškaraca. I na kraju, postojale su i neke intelektualne skupine koje su se vodile pretpostavkom da se ozbiljna revolucija može sprovesti isključivo unošenjem promjena unutar strukture ličnosti, odnosno oslobođenjem žene od tereta njezine vlastite spolnosti (p. 362). U svakom slučaju, veliku su važnost zadobile ponajprije teme vezane uz sferu seksualnosti, vlast žene nad vlastitim tijelom te pitanja spolne i rodne (ne)jednakosti.

Prvo značajnije djelo inspirirano navedenim problematikama jest Spolna politika (1969) Kate Millett. ${ }^{43}$ Ova je doktorska disertacija, na neki način, inaugurirala feminizam novog doba, zatvorila neke stare rane, te otvorila nova polja interesa i djelovanja. Prema mišljenju Millett, politika je spolno tj. seksualno uvjetovana i stoljećima se konstruira na temeljima i principima muške spolne moći ${ }^{44}$. Uvlačeći se u sve pore društva, stvara duboko ukorijenjen patrijarhalan sustav moći kroz koji razmišljamo i djelujemo, na koji se oslanjamo. Glavnoga i odgovornoga za legitimizaciju ovako nepravedno utemeljene ideologije spolne nadmoći Millett drži upravo Freuda, odnosno sve frojdovske i postfrojdovske teoretičare koji, tvrdi, propagiraju jeftini biološki esencijalizam: „sada se znanstveno može reći da je ženama podložnost prirođena, a da su muškarci dominantni, seksualniji, te stoga imaju pravo seksualno podčiniti ženu koja uživa u svojoj potlačenosti i zaslužuje ju jer je po samoj svojoj prirodi tašta, glupa i jedva bolja od barbara, ako je uopće ljudsko biće“ (Millett 1977, p. 203). Iako su mnoge feministice nove generacije, poput Sarah Kofman, Juliet Mitchell i Jacqueline Rose, uvjerljivo stale $u$ obranu Freuda i njegovih teorija o ženskom sazrijevanju i seksualnosti, tvrdeći kako psihoanaliza ne prikazuje seksualni identitet kao urođenu ili

\footnotetext{
${ }^{43}$ Neki smatraju kako je Ženska mistika (The Feminine Mystique) Betty Friedan, objavljena 1963. godine, prvo značajnije feminističko djelo, u kojem autorica progovara o nezadovoljstvu žena u poslijeratnom društvu izobilja. Friedan govori o ženama koje su za vrijeme rata, umjesto muževa, radile u tvornicama. No, po povratku muškaraca s ratišta, ostajale su bez posla i prisilno su vraćene u poziciju čuvarica ognjišta. O njihovoj želji za neovisnosti Friedan piše u vrlo otvorenom i inovativnom novinarskom stilu.

${ }^{44}$ Falokracija.
} 
biološku bit već kao posve nestabilnu subjektnu poziciju koja se kulturno konstruira kroz proces djetetova ulaska u društvo, Millett apsolutno sve Freudove teze o ženskoj seksualnosti s prezirom odbacuje, optužujući ga za mizoginiju ${ }^{45}$.

O službeno afirmiranom osjećaju muške superiornosti piše i Shulamith Firestone u knjizi Dijalektika spolova ${ }^{46}$ (1970). Autorica ističe kako su marksizam i psihoanaliza ženin već ionako stoljećima podređen položaj samo dodatno legitimizirali. Jer, sama je priroda, ističe Firestone, ženu prikovala za ognjište. Nakon udaje i poroda ženi je dodijeljena briga o kućanstvu i djeci, istodobno očekujući suradnju muškarca u obavljanju svakodnevnih dužnosti. S vremenom, međutim, muškarac je ovu „suradnju“ pretvorio u „supremaciju““47. Njegov svijet postaje onaj izvan kuće, a ženin onaj unutar četiri zida. Dok žena poslušno preuzima pasivan položaj unutar bračne zajednice, obitelji i društva, muškarac ulogu onog koji dominira i odlučuje.

O spolnoj i rodnoj problematici raspravlja i Gayle S. Rubin u djelu Razmjena žena ${ }^{48}$ (1975). Rubin analizira Freudovu i Lacanovu teoriju seksualnosti, kao i Lévi-Straussov istraživački rad, te zaključuje kako je do nesporazuma došlo poglavito jer su se nastojale prekrojiti biološke pretpostavke. Muškarac i žena, navodi Rubin, jesu anatomski i fiziološki gledano drugačija bića, a njihove spolne razlike svakako utječu na psihičke funkcije i karakterne osobine, i to su neoborive pretpostavke. Ono što, međutim, stvara pomutnju i predmet je prijepora jest rodna nejednakost. Nova borba za jednakost spolova, zaključuje Rubin, mora voditi računa o društvenim i kulturnim okolnostima koje ženu dovode u submisivni položaj, jer nije priroda ta koja nas razdvaja, već naše shvaćanje pojedinih uloga koju svatko od nas u društvu ima.

I dok su se autorice s kraja šezdesetih i početka sedamdesetih žestoko obračunavale s Freudom, sredina sedamdesetih godina obilježena je proizvodnjom tekstova koji, na neki

\footnotetext{
${ }^{45}$ Iako Millettin prvijenac ostaje vrijedan dokument vremena, radikalne teze autorice o ženi kao potlačenom biću koje mora prozreti lažnu ideologiju vladajućeg patrijarhata i tako postati slobodnom samu autoricu dovode u poziciju one koja se priklanja seksističkim stavovima. Iako je u feminističkoj teoriji termin političke korektnosti bio od iznimno velike važnosti, same feministice nisu uvijek pratile tu misao.

${ }^{46}$ The Dialectic of Sex: The Case for Feminist Revolution. Zajedno s Kate Millett te Anne Koedt, Firestone je bila pripadnica tzv. njujorškog feminističkog pokreta.

${ }^{47}$ Firestone smatra kako se uvjeti za razvoj edipske paradigme stvaraju upravo radi ove podjele na muške i ženske uloge unutar obiteljske zajednice.

${ }^{48}$ The Traffic in Women: Notes on the Political Economy of Sex.
} 
način, rehabilitiraju frojdovsku psihoanalizu. Franco Restaino (2002), u povijesnom pregledu feminističkih pokreta, ističe kako se radi o znanstvenicama koje pokušavaju pomiriti feminizam i psihoanalizu, odnosno borbu za rušenje staklenih stropova nastaviti upravo putem psihoanalitičkih postulata (p. 42-47). Zvuči paradoksalno i nije ovaj napor američkih i engleskih znanstvenica naišao na malen otpor, kako u akademskom okruženju, tako i šire. No, s vremenom ove interpretacije Freudovih, ali i Lacanovih, tekstova postaju sve izraženije i prisutnije u feminističkim krugovima, dok radikalni feminizam prve polovice sedamdesetih polako jenjava.

Prva među takvim autoricama, ona koja potpunu reviziju Freudovih tekstova drži nužnom i korisnom, jest Juliet Mitchell, a manifest ove nove umjerene feminističke struje, koja pomiruje dvije zaraćene strane, njezina je knjiga Psihoanaliza i feminizam (1974). Mitchell smatra kako je frojdovska psihoanaliza ponudila vrijedne temelje za daljnja istraživanja fenomena ženskog i to prije svega jer je nesvjesno učinila svjesnim. Napominje i kako Freud u radovima poput Totem i Tabu (1913) te Mojsije i monoteizam (1939) vrlo jasno razlikuje prirodu od kulturno-povijesnih okolnosti koje su dovele muškarca i ženu u poziciju superiorne moći, odnosno plahe i pasivne inferiornosti. Patrijarhalni sustav vrijednosti, ističe Mitchell, stoljećima je duboko ukorijenjen u naše društvo i sada već pripada jednom kolektivnom sjećanju čovječanstva. Obitelj i obiteljski odnosi, odnos muža i žene, muškarca i žene unutar zajednice nisu posljedica anatomsko-fizioloških razlika, već povijesnih i evolucijskih čimbenika, kojima se nastojao uvesti red unutar čopora/zajednice. Mitchell zaključuje kako je Freudovo viđenje ljudske psihe bilo mnogo alternativnije od onog kako su ga feministice često prikazivale. Prema njegovom mišljenju čovjek je rođen kao biseksualni pojedinac, s izraženijim obilježjima jednoga spola te se s vremenom i unutar zajednice pretvara u spolno određeno društveno biće, u muškarca ili u ženu (Mitchell, 1974).

Još jedno avangardnije viđenje Freudove psihoanalitičke teorije objavljuje psihoanalitičarka Dorothy Dinnerstein u knjizi Sirena i minotaur (1976). U pokušaju da težište s edipskog prebaci na prededipsko, te tako snažno označi ulogu žene kao majke, Dinnerstein iz grčke mitologije preuzima likove sirene i minotaura kako bi metaforički prikazala dvije dominantne karakteristike muškog i ženskog spola. U prededipskoj fazi dijete je vezano uz majku, ono je majčin centar svijeta i majka je njegov. To, međutim, ne traje dugo. Opsesivna i posesivna simbioza majka-dijete prekinuta je ulaskom trećeg - Oca. U tom trenutku djevojčica se oslobađa veze s majkom i preuzima ulogu sirene, ulogu one koja zavađa i traži dominantnu 
figuru, onog koji će njome ,zavladati““. Dječak, s druge strane, oslobađa se veze s majkom na način da se iz uloge „kontroliranog objekta“ pretvara u ulogu „subjekta koji kontrolira“. Edipska faza dječaka oslobađa majčine kontrole, no istovremeno, ugledajući se na oca, on postaje taj koji dominira. Na taj način, zaključuje Dinnerstein, postaje evidentno kako je ekskluzivna uloga koja je majci dodijeljena, u pogledu brige i njege djeteta, ključan trenutak o kojem razvoj edipskog kompleksa potpuno ovisi (Dinnerstein, 1999).

I Nancy Chodorow 1978. objavljuje knjigu kojom iskazuje iznimno pozitivan zaključak Freudovih teza o seksualnom sazrijevanju i razlikama među spolovima. The Reproduction of Mothering. Psychoanalysis and the Sociology of Gender naslov je djela u kojem Chodorow razmatra pitanje majčinstva, te navodi prededipski stadij kao ključan trenutak za stvaranje majčinskih instinkta kod ženskog djeteta. Prema Chodorow, djevojčica ostaje u simbiotskoj vezi s majkom na drugačiji način negoli dječak. Obzirom da se radi o odnosu između dvije jedinke jednakog spola, žene-majke i žene-djeteta, razvija se narcističko-simbiotski odnos unutar kojeg se djevojčica ogleda u majci. Ono što majka čini, želi i ona jednog dana. Poziciju one koja brine, koja je posvećena i predana, želi i ona. Taj osjećaj u malenoj se ženi rađa potpuno prirodno. Roditeljstvo i briga o ognjištu, ističe Chodorow, nisu nešto što žene postavlja u inferioran položaj, naprotiv, to žene stavlja u poziciju onih koje preuzimaju donošenje odluka, koje imaju snagu i moć predvođenja obitelji. I to upravo iz razloga jer brinu o budućim naraštajima (Chodorow, 1978).

Po svemu sudeći, šezdesete i sedamdesete bile su uistinu revolucionarne godine, vrijeme radikalnih društvenih i kulturnih promjena. Poimanje i prihvaćanje položaja čovjeka, muškarca i žene, unutar društvene i obiteljske zajednice, unutar svijeta rada, radikalno su se izmijenili, a seksualnost, rodna i spolna nejednakost, postale su centralne teme raznorodnih društvenih pokreta. Iako su se sve pripadnice tadašnjih feminističkih pokreta jednoglasno borile protiv šovinizma i patrijarhalnosti te zalagale za politiku i društvo izvan binarnih opreka, za povijest, znanost i umjetnost tumačene iz perspektive čovjeka, ne muškarca, poruke s kraja šezdesetih i početka sedamdesetih bitno su se razlikovale od onih s druge polovice sedamdesetih, koje su, na neki način, inaugurirale događanja osamdesetih godina. I dok su prve inzistirale na potpunom oslobođenju od spolnosti i poništenju bioloških razlika, ne bi li se uspostavila ravnoteža i stvorio osjećaj jednakosti, druge su nastojale pomiriti feminizam i psihoanalizu, prihvatiti antropološka tumačenja o različitosti spolova i specifičnim urođenim osobinama koje ženu, odnosno muškarca čine jedinstvenim. Rubin, 
Mitchell, Chodorow, Dinnerstein, Rose priznale su postojanje binarnih opreka, muževnog i Ženstvenog, ali samo kao instalacija simboličkog poretka. Stoga predlažu njihovu potpunu dekonstrukciju, kako bi se falokratičan patrijarhat i hijerarhijski sustav vrijednosti poništili, a ženska moć i uspjeh rehabilitirali. No, to se, ističu ove feministice, može dogoditi jedino ako ono što razlikuje ženu od muškarca, što se naizgled čini kao njezina slabost i mana, učini njezinom najvećom vrlinom i snagom. U različitosti se, dakle, krije ključ ženskog uspjeha i jedino se njome princip podređenosti i nadređenosti, uključenosti i isključenosti, mogu potpuno neutralizirati. 


\title{
I. II. III. Žensko, ženstveno, tekstualno
}

Feministički su se pokreti 60 -ih i 70-ih godina ticali uglavnom društvenih i političkih promjena, problematike odnosa muškaraca i žena u poslovnoj, političkoj i obiteljskoj sferi. U želji da legitimiraju vlastitu borbu te ostvare cilj i unutar institucija, aktivistice ovog razdoblja upravo kroz medij jezika ovu političku agitaciju proširuju na domenu kulture i obrazovanja.

U centru kulturno-političkih događanja nalaze se feminističke kritičarke koje svojim radom nastoje razotkriti i poništiti patrijarhalne prakse, a pionirka među njima je, već spomenuta, Kate Millett, odnosno njezino djelo Spolna politika ${ }^{49}$ (1969). Millett u knjizi raspravlja o društvenim i političkim utjecajima muške spolne nadmoći, o ustrajnosti i prodornosti feminističkih borbi prethodnog i aktualnog stoljeća te negativnom učinku koji je psihoanaliza imala na proces ženske emancipacije. Osvrćući se na negativnu ideologiju američke nove kritike, koja je u to doba zauzimala dominantnu poziciju unutar akademskih struktura, autorica se zalaže za istraživanje društvenog i kulturnog konteksta u svrhu pravilnog razumijevanja književnog teksta. Moi ističe kako je najdojmljiviji aspekt Millettine kritičke studije odvažnost s kojom tekst čita „protiv struje“ (2007, p. 45) te potpuno zanemarivanje onoga što se tih godina smatralo konvencionalnim poštivanjem autoriteta i namjera autora:

\begin{abstract}
Njezina analiza otvoreno uspostavlja perspektivu drukčiju od autorove, te pokazuje kako upravo takav sukob između čitatelja i autora/teksta može razotkriti skrivene premise nekog djela. Millettina se važnost kao znanstvenice nalazi u njezinoj neumornoj obrani čitateljičina prava da uspostavi vlastitu točku gledišta, odbacujući usvojenu hijerarhiju teksta i čitateljice [ ... ] Njezin stil pripada tvrdokornome huliganu koji u svakoj prilici osporava autorov autoritet. Njezin pristup uništava prevladavajuću predodžbu čitateljice/kritičarke kao pasivne/ženstvene recipijentice autoritarnoga diskursa, a baš je to primjereno feminističkim političkim ciljevima. (Moi 2007, p. 45-46)
\end{abstract}

Teza o spolnoj politici kao o kontinuiranom društveno-kulturnom procesu pomoću kojeg vladajući spol pokušava zadržati i proširiti vlastitu moć proteže se cijelom knjigom. Suprotstavljajući se teoretičarima nove kritike, suprotstavljajući se autorskom autoritetu i autoritarnom diskursu, Millett zadaje „snažan udarac u solarni pleksus patrijarhata“ (Moi 2007, p. 47). Iako se Millettino djelo predstavlja gotovo kao klasik feminističke kritike, što

\footnotetext{
${ }^{49}$ Spolna politika podijeljenja je u tri dijela: Spolna politika, Povijesna pozadina, Književna refleksija. U prvome se dijelu raspravlja o odnosu moći između spolova, drugi dio nudi pregled feminističkih borbi 19. i 20. st., a u posljednjem se odjeljku pokušava dokazati kako spolna politika preuzima moć u književnim djelima, nažalost, u djelima isključivo muških autora.
} 
zbog činjenice da je njime uspjela premostiti jaz između institucionalne i neinstitucionalne kritike, što zbog još važnije činjenice da je uspostavila potpuno nov kritički pristup tekstu, oduzimajući autoru povlašteno pravo na njega, te unoseći sve ono kontekstualno i paratekstualno kao nužno za potpunu i kvalitetnu percepciju i recepciju, Moi ističe kako Millett u suštini nudi pretjeranu analizu sadržaja, istovremeno oduzimajući pozornost formalnim strukturama teksta, a optužuje ju i za izbjegavanje suočavanja s problematikom čitanja feminističkih tekstova, odnosno tekstova u ženskom autorstvu (p. 53-54).

Izraženiji interes za jezični aspekt feminizma i feminističke kritike pokazala je spisateljica Mary Ellmann. U knjizi Razmišljanje o ženama (1968), za razliku od Millett, autorica raspravlja o isključivo psiholingvističkim aspektima novog feminizma. Minuciozno istražujući područje kritike koja se bavi predodžbama žena, poglavito u djelima muških pisaca, kao i područje kritike koja obuhvaća recenzije i komentare muških kolega o djelima koja su napisale žene, Ellmann detektira neprimjerenu intelektualnu naviku zapadnog čovjeka da razmišlja u okvirima ,seksualnih analogija“ (Ellmann 1986, p. 6), u smislu da pojave i iskustva shvaćamo u okvirima naših izvornih spolnih razlika: „Vanjskom se svijetu obično ne nameću samo seksualni okviri već i seksualni nazori. Sve su forme obuhvaćene našom koncepcijom muške i ženske naravi““ (p. 8). Seksualnim se analogijama Ellmann najtemeljitije bavi u poglavlju naslovljenom Falička kritika. Upravo u tom dijelu knjige, koji ujedno zauzima i najveći prostor, autorica navodi neke od glavnih stereotipa ženstvenosti koje muški pisci i kritičari najčešće prikazuju: bezobličnost, pasivnost, nestabilnost, ograničenost, pobožnost, materijalnost, duhovnost, iracionalnost, popustljivost. Izuzetno izražena pristranost muških kolega, koja Ellmann potpuno zaokuplja, s jednog općedruštvenog i kulturnog aspekta kao da se premjestila u onaj znanstveni: „Prema knjigama koje su napisale žene postupa se kao da su i same žene, a kritika se u najboljem slučaju upušta u intelektualno mjerenje poprsja i bokova“ (p. 29). Prema Ellmann, muževnost i ženstvenost isključivo su društveno konstruirani termini koji ni na koji način ne opisuju stvarnu čovjekovu prirodu, a ujedno ih je i nemoguće tekstualno fiksirati jer su, tvrdi autorica, u kontinuiranom procesu jezične dekonstrukcije. Upravo iz tog razloga Ellmann odlučno tvrdi kako je ,nemoguće odrediti seksualnu rečenicu“ (p. 172), uzimajući ipak u obzir činjenicu da su, povijesno promatrajući, žene kroz dugi niz godina bile osuđene na jezik osjećaja. Ne dolazeći u bliski kontakt $\mathrm{s}$ iskustvima poput ratovanja, dalekih istraživačkih putovanja, političkih ili kulturnih revolucija, žene se nisu uspjele autoritarno probiti na aktualnu kulturnu scenu. 
Situacija se, međutim, 60-ih godina drastično počela mijenjati, tako da su društvene promjene, u sklopu neofeminističkih struja, stvorile uvjete za novu vrstu ženskog pisma.

Sredina 70-ih predstavlja okosnicu unutar kontrakulturnih feminističkih pokreta, a tih se godina i znanstveni pristup umjetničkoj produkciji bitno mijenja. Moi ističe kako je u tom razdoblju dominantan trend postao ginocentrični istraživački pristup, odnosno nakon 1975. godine znanstveni su interes počela sve više zaokupljati djela spisateljica (Moi 2007, 77-78). Ta druga faza istraživanja obilježena je produkcijom tekstova kojima autorice nastoje odrediti žensku tradiciju, inzistirajući na tezi kako ona ipak proizlazi iz još promjenjivog odnosa između spisateljica i društva, te na taj način specifično žensku percepciju svijeta smatraju odrazom njihovih iskustava unutar društva, a ne odrazom bioloških kvaliteta.

Krajem 70-ih pojavilo se nekoliko većih studija o spisateljicama kao dijelu specifično ženske supkulture, a možda najambicioznija nova teorija ženske jezične strategije i kreativnosti sadržana je u opsežnom djelu Sandre M. Gilbert i Susan Gubar, Luđakinja u potkrovlju (1979). Ovaj dojmljiv feministički priručnik predstavlja se kao model za alternativno razumijevanje prirode i dinamike ženske kreativnosti. Autorice raspravu otvaraju tezom o falocentričnom mitu kreativnosti, ističući kako je dominantna patrijarhalna ideologija stoljećima predstavljala umjetničku kreativnost kao temeljno mušku kvalitetu, a autora istovremeno okrunila kao jedinog izvora smisla i značenja teksta (Gilbert; Gubar 1979, p. 13). Djelo je moguće svesti na tri ključne problematike. Prva je ona koja razmatra žensku tekstualnu strategiju kao onu koja se sastoji od neprestanih revidiranja, dekonstruiranja i rekonstruiranja. Lik „luđakinje“ lik je žene koja odbacuje podređenu ulogu koju joj je patrijarhat namijenio $\mathrm{i}$ prihvaća jedan potpuno nov $\mathrm{i}$ jedinstven način pisanja. $^{50} \mathrm{U}$ dugostoljetnoj izoliranosti vlastitog potkrovlja, žena je, prema mišljenju Gilbert i Gubar, tekstualnu strategiju dovela do kreativnog maksimuma. Autorice ističu kako je glavni sastojak, zaslužan za konačni uspjeh ovih novih djela, upravo ludilo (p. 70-80). Naime, ženska kreativna shizofrenija, kojom ženin osjećaj podvojenosti i fragmentiranosti biva označen, simbol je izuzetno sofisticirane taktike. Moi ističe kako je „luđakinja u potkrovlju“ žena dvoličnih/podvojenih vještina, žena čija svijest, poput Sfinge, postaje muškarcu neprovidna i neprohodna, ona je žena ,čiji um ne dopušta da ga muška misao penetrira faličkim sondiranjem“ (Moi 2007, p. 87). Sljedeće razmatranje Gilbert i Gubar tiče se

\footnotetext{
${ }^{50}$ Žensko pismo ove autorice dovode u vezu s palimpsestom. Postoji opresivan i dominantan sustav znakova,
} jednostavan i lako uočljiv, no postoji i njegova nevidljiva pozadina, ona koja sadrži potisnutu žensku povijest. 
problematike autorstva. Inzistirajući na specifično ženskim karakteristikama pisanja, specifično ženskim vokabolarom i sintaksom, te specifično ženskoj točki gledišta, u Gilbert i Gubar autorski glas dolazi u prvi plan, a likovi su često promatrani kao autoričine dvojnice, odnosno kao materijalizirane predodžbe njezinih duševnih stanja. U tom smislu, autorice su mišljenja da svaki ,ženski tekst“ skriva stvarnu ženu, a zadaća kritičarke je da otkrije njezino postojanje (Gilbert; Gubar 1979, p. 85-90). Ukoliko tekst nije sama autorica, onda je barem produžetak njezinih podsvjesnih mehanizama, zaključak je ovog dijela knjige. No, inzistiranje na konkretnom autoru kao na suverenom autoritetu koji jedini osigurava egzaktno tumačenje teksta već je 1968. osudio Roland Barthes u tekstu Smrt autora ${ }^{51}$ :

\begin{abstract}
Kada je jednom Autor uklonjen, želja da se odgoneta tekst postaje potpuno jalova. Dati tekstu Autora znači nametnuti tom tekstu granicu, znači opskbiti ga konačnim označenim, znači zatvoriti to pisanje. Takvo shvaćanje odgovara kritici, pa ona onda sebi prisvaja važnu zadaću da otkrije Autora (ili njegove hipostaze: društvo, povijest, psihu, slobodu) ispod djela: kada je Autor pronađen, tekst je „objašnjen“ - pobjeda je kritičareva. (Barthes 1977, p. 147)
\end{abstract}

Moi, međutim, tvrdi kako inzistiranje na sveprisutnom ženskom autorskom glasu vraća tekst pod nadzor tradicionalne patrijarhalne ideologije kojom, kako je već rečeno, vladaju hijerarhijski sustavi mišljenja. Iz tog razloga, djelo Gilbert i Gubar smatra u najmanju ruku diskutabilnim (p. 97-99). Posljednja ključna točka Luđakinje u potkrovlju jest točka estetike. Postoji li specifično ženska estetika te koji je njezin kanon pitanje je na koje autorice nastoje dati odgovor. Prema njihovom mišljenju, žensko pisanje može zaživjeti jedino kao kompaktno strukturirana organska cjelina, stoga su cjelovitost, jedinstvo i totalitet osnovne estetske vrijednosti nove ženske umjetnosti riječi:

\begin{abstract}
Korpus njezine vlastite umjetnosti, leži oko nje u komadićima, rastavljen, zaboravljen, razjedinjen. Kako da ga ne zaboravi i da u njemu boravi, kako da ga sastavi i postane njegovim sastavnim dijelom, kako da ga ujedini i time stekne vlastito jedinstvo, svoje vlastito ja? (Gilbert; Gubar 1979, p. 98)
\end{abstract}

No, jesu li to ideali kojima žensko pisanje mora težiti ili je riječ o još jednom naslijeđu patrijarhata, u poglavlju o ginocentričnim perspektivama 70-ih pita se Toril Moi.

\footnotetext{
${ }^{51}$ Proglasivši smrt autora, Barthes je istaknuo značenje i aktivnost primatelja. Prema njegovom mišljenju, svaki je tekst multidimenzionalan prostor u kojem se intertekstualne i intermedijalne silnice neprekidno prepliću, a njegovo podrijetlo, odnosno autorstvo s teškoćom možemo definirati. U nemogućnosti da kontrolira tekst $\mathrm{i}$ njegovo značenje, Barthes je autora prognao iz teksta, a čitatelju dao mogućnost da upravo činom čitanja producira značenje djela (Barthes, 1977).
} 
Osim činjenice da odbijaju priznati odvojenost prirode (ženskog) od kulture (ženstvenog), Moi autoricama zamjera ,robovanje tradicionalnim patrijarhalnim estetskim vrijednostima nove kritike“" (Moi 2007, p. 99). Pozivajući se na Derridinu dekonstrukciju i Speculum Luce Irigaray, u kojima se patrijarhalna misao prikazuje kao ona koja oblikuje estetske kriterije na temelju središnje pretpostavke Falusa, odnosno Logosa, Moi ističe kako su upravo cjelovitost, jednostavnost i jedinstvenost odraz faličkih estetskih kriterija, a nasuprot tome su kaotičnost, fragmentiranost i manjkavost sinonim za žensku estetsku perspektivu (p. 96-101). U tom smislu, Gilbertina i Gubarina teza o ženskom tekstu kao o kompaktnoj monolitnoj cjelini ide u korist faličkoj estetici, a radikalno proturječje između pitanja politike i pitanja estetike dolazi do maksimalnog izražaja.

Ginocentrična perspektiva i proučavanje ženskih tekstova otvorile su mogućnost proboja konkretnijih teorijskih razmatranja u područje feminističke kritike. Jedan od prvih radova kojim su se pokušala definirati formalna i sadržajna načela feminističke kritike jest onaj Annette Kolodny Neke bilješke o definiranju feminističke kritike, objavljen u časopisu Critical Inquiry 1975. godine. Kolodny problematici proučavanja ženske strategije i umjetnosti, kao odvojenih kategorija, pristupa vrlo oprezno. Određujući stilsku, sintaktičku, leksičku ili bilo kakvu drugu jedinstvenost ženskog pisma, ulazimo u prostor vječnog sukoba prirode i kulture, odnosno isticanjem osobitosti i jedinstvenosti ženskog pisma nužno određujemo i kvalitativni udio rodnog i spolnog (Kolodny 1975, p. 76-78). S tim u vezi, Kolodny predlaže metodu feminističkog komparativizma, koji omogućuje da induktivnim putem, čitajući i analizirajući pojedine autore i njihova djela kao zasebne i jedinstvene cjeline te sabirući ih u neke tipično ženske stilske obrasce, dođemo do zaključka o ženstvenom stilu (p. 79-80). Iako Kolodny (p. 83-84) smatra da je potraga za iskustvom, odnosno zbiljom iza fikcije, nužna za proučavanje i prosudbu tekstova, Moi (2007, p. 105-106) ističe kako, inzistirajući na rigoroznim metodama analize stila, njezina razmatranja formalno prate teoriju nove kritike. Osobita naklonost rigidnijem teorijskom alatu potvrđuje se i izjavama o nužnosti odvajanja političke ideologije od estetskih sudova (Kolodny 1975, p. 89), kao i nepostojanju feminističke kritičke analize kojom bi se omogućio sustavan i kompletan metodološki pristup ženskom tekstu (Kolodny 1980, p. 6-20). Odbacujući psihoanalizu i marksizam, Kolodny sužava krug onih teorijskih pravaca koji imaju legitimno pravo sudjelovati u stvaranju prepoznatljive feminističke kritike, ostavši, na neki način, intelektualno pristrana. 
Nešto umjereniji pristup proučavanju ženskih tekstova ima američka feministička kritičarka Elaine Showalter, čije su glavne teze o feminističkoj teoriji izložene u člancima Prema feminističkoj poetici (1979) te Feministička kritika u divljini (1981). Analizirajući psihodinamiku ženske kreativnosti, autorica ističe važnost sustavnog izvantekstualnog ginocentričnog pristupa. Pokazujući slab interes za kruto formalno teorijsko istraživanje teksta kao prostora znakova i označivanja, primarno se priklanja onim znanstvenim područjima koja su, u možda najvećoj mjeri, pridonijela razumijevanju ženske supkulture: antropologiji, sociologiji, povijesti i psihologiji. Prema Showalter, svaki je ženski tekst direktan ili indirektan prijenos autentičnog ljudskog iskustva. Da bismo mu adekvatno pristupili nužna su nam iskustvena saznanja. Tek obraćajući pozornost na izvantekstualne i kontekstualne veze, možemo u potpunosti spoznati smisao nekog od elemenata ženskog teksta: teme, strukture, žanrovskog opredjeljenja (Showalter 1979, p. 20-30). Drugim riječima, primarni bi interes feminističke kritičarke trebali biti povijesni, antropološki, psihološki i sociološki aspekti ženskog teksta. Dvije godine kasnije, Showalter razmatra i potvrđuje ove iste teme, s laganim odmakom od potpunog izbjegavanja teorijskog aparata. Navodeći lingvistiku, psihoanalizu i kulturalnu teoriju kao osnovne alate za proučavanje teksta, autorica ipak prihvaća nužnost teorije u borbi za red, sustavnost i vlastiti kanon ${ }^{52}$ (Showalter 1981).

Jasniju i konkretniju viziju o tome što bi ženski studiji i feministička teorija trebali predstavljati ima Myra Jehlen. 1981., u članku Arhimed $i$ paradoks feminističke kritike, autorica detaljno izlaže razloge postojanja tzv. feminističkog paradoksa, činjenice da feministice ističu nepostojanje prostora izvan patrijarhata, položaja s kojeg bi se žene mogle izraziti, dok istovremeno inzistiraju na jasno definiranom feminističkom antipatrijarhalnom diskursu. Nepostojanje teorijskog uporišta podrazumijeva i vrlo upitan kritički stav, ističe Jehlen (1981, p. 575-585). Prema njezinom mišljenju, dosadašnja feministička promišljanja klize u „radikalni skepticizam“ (p. 575), a ginocentrične kritičarke, poput već spomenutih Gilbert i Gubar te Showalter, pretjerano su usredotočene na žensku tradiciju, oduzimajući sva prava i zasluge tradicionalnom kanonu i stvarajući neku vrstu ,ženske enklave, odvojene od svemira maskulinističkih pretpostavki“ (p. 576). Upravo iz tog razloga Jehlen priželjkuje povratak feminističke kritike na muško tlo, u prostor zrcala, gdje je moguće jasnije utvrditi

\footnotetext{
${ }^{52}$ Upravo se u naslovu Feministička kritika u divljini krije autoričina poruka o nužnoj teorijskoj sustavnosti $\mathrm{i}$ kategorizaciji „eklektične i široke“ (Showalter 1981, p. 182) ženske književnosti.
} 
postojanje razlika između muškog i ženskog pisanja (p. 584), s naglaskom na stvaranju nove alternativne ženske točke gledišta:

\begin{abstract}
Ponešto poput Arhimeda, koji je da bi podigao zemlju svojom polugom tražio neko drugo mjesto na koje bi postavio sebe i svoje uporište, čini se da je feministicama koje propituju pretpostavljeni poredak kako prirode, tako i povijesti - te si tim prijedlogom izmiču tlo pod vlastitim noga - potrebna alternativna podloga. (p. 575-576)
\end{abstract}

Da su tekstovi kodirane poruke autorova glasa te da svaka ispravna interpretacija teksta nužno podrazumijeva potpuno odvajanje politike od estetike, Jehlen drži nedvojbenim. Moi ističe kako u ovom slučaju termin „kritička objektivnost“ dolazi u pitanje jer je očito da se, prema tvrdnjama autorice, ključ razumijevanja teksta krije isključivo i unutar njega, odnosno glas teksta isključivo je autorov glas (Moi 2007, p. 119). Pozivajući se na ulomak iz teksta Comment on Jehlen Sue Warrick Doederlein, Moi Jehlenino inzistiranje na jednom i jedinom ispravnom tumačenju teksta drži neprihvatljivim:

\begin{abstract}
Nova otkrića u lingvistici i antropologiji svakako su osporila svaku tezu o autonomnom umjetničkom djelu čiju svetost ne smijemo oskvrnuti i u čiji prostor ulazimo (u poniznoj objektivnosti) jedino stoga ,da bismo mu osigurali pouzdano čitanje“. Feminističke kritičarke mogu (oprezno) preuzeti određene postavke najnovijih maskulinističkih hipoteza koje će nam dopustiti da se više nikada ne ispričavamo zbog ,pogrešnoga čitanja“ ili ,pogrešne interpretacije“ nekog teksta. (Doederlein 1982, p. 165-166)
\end{abstract}

Pokušavajući riješiti problem vrednovanja umjetničkog djela koje se smatra estetski vrijednim, ali politički zazornim, ili obrnuto, Jehlen odlučno zagovara odvajanje politike od estetike. No, takvo viđenje kritike prilično je udaljeno od moderne kritičke teorije koja se protivi konačnom zatvaranju teksta. Naime, estetski vrijednosni sudovi nisu uvijek i ne mogu biti uvijek politički nevini. To prije svega ovisi o povijesnom i kulturnom kontekstu unutar kojeg se neko djelo pojavljuje: ,zahtijevati jednostavan i nezamršen odgovor na iznimno složen problem odnosa između politike i estetike svakako je najreduktivniji pristup od svih“ (Moi 2007, p. 122). Moi ističe kako Jehlenini pogledi na političko i estetičko potkopavaju najosnovnija načela feminističke kritike, odnosno kritike uopće. Nepristran kritički sud, prema mišljenju Moi, podrazumijeva potpunu dekonstrukciju opreka, pa tako i opreke političkog i estetičkog: „feminizam mora biti svjestan političnosti estetičkih kategorija kao i implicitne estetičnosti političkih pristupa umjetnosti“ (p. 123). 


\section{O ŽENSKOM IDENTITETU}

\section{I. SEKSUALIZIRANO ŽENSKO PISMO}

\section{I. I. Luce Irigaray}

Luce Irigaray psihoanalitičarka je psiholingvističkog zaleđa s francuskim doktoratom iz područja filozofije. Karijeru je započela, zajedno s Juliom Kristevom, kao učenica Jacquesa Lacana, no nakon objavljivanja doktorske disertacije Spéculum de l'autre femme (Spekulum druge žene) iz 1974., kojom je kompromitirala Freudovo i Lacanovo viđenje ženskosti, izbačena je iz Lacanove École freudienne u Vincennesu. Ne slažući se s dotadašnjim psihoanalitičkim definicijama spolne različitosti i ženske seksualnosti, smatrajući kako su psihoanaliza i filozofija stvorile jednostranu maskulističku zapadnu kulturu, temeljenu uglavnom na vizualnim pretpostavkama, Irigaray pokušava, postupcima dekonstrukcijske kritike, neutralizirati, a zatim i poništiti, patrijarhalan sustav mišljenja.

Za frojdovsku je psihoanalizu spolna različitost prije svega vizualan odraz. Ona označava vizualnu prisutnost, odnosno vizualnu odsutnost, normu ili otklon od iste. Vizura, zrcalna refleksija definira jedno biće superiornijim jer ,posjeduje“ i drugo biće inferiornijim jer mu očito nešto nedostaje. Zrcalni odraz, ističe Irigaray, predstavlja ženu kao prazan prostor obavijen osjećajima žudnje i zavisti ' $z a$ ' i 'prema' nečemu što ne posjeduje i/ili ne može doseći (1974, p. 70). Zrcalo i zrcalnu refleksiju Irigaray zamijenjuje spekulumom - konkavnim zrcalom koji sliku (imago) ne reflektira, već produbljuje. Mijenjajući tako perspektivu, mračan i prazan prostor pretvara u bogato i kompleksno mjesto seksualne ugode i užitka, odnosno prostor ništavila i manjkavosti u beskonačan prostor različitosti (p. 182-183). Za tradicionalnu je frojdovsku psihoanalizu zrcalna refleksija ključna u formiranju identiteta. Njome započinje odvajanje od dijadnog imaginarnog poretka te nastupa proces ulaska $u$ prostor simboličke trijade, njome subjektni odnosi bivaju uspostavljeni. No, Irigaray tvorbu identiteta odmiče od prostora zrcala, te je, dakako, približava spekularizaciji, ističući uspostavu subjekta, muškog ili ženskog, kao posljedicu povezivanja vlastitih unutarnjih veza, kao i veza s okolinom (p. 20). Subjekt nije, prema njezinom mišljenju, posljedica zrcalnog odraza, on nije negativ tuđe refleksije. Zapadni filozofski diskurs, tvrdi Irigaray, vidi ženu kao 
„,zrcalni odraz muškog subjekta“, a ženstvenost kao „negativ muževne refleksije“ (p. 20). Žensko i ženstveno postaju tako naknadne, sekundarne tvorevine, čija su svojstva podređena primarno prolaskom kroz imaginarij muškog. U tom smislu, muškarac je nositelj ženskog identiteta, a žena je, napominje Irigaray, psihološki ogoljena. Ona vlastiti identitet, bez prisutnosti muškog subjekta, ne prepoznaje. U odsutnosti zrcalnog odraza, žena nestaje. No, Irigaray zaključuje kako je za Freuda, ali i za mnoge druge zapadne filozofe, žena ustvari zrcalo vlastite muževnosti. Bez nje, i njezine „zavisti na penisu“, moć zavisti i žudnje, koje muškarca jačaju i hrane, slabe i nestaju: „Kastrirati ženu znači upisati je u zakon iste žudnje, žudnje za istim“ (p. 64). Drugim riječima, ženska zavist i žudnja u funkciji su jačanja muške psihe i upravo se u tome krije razlog smještanja žene 'izvan'/'onkraj' reprezentacije, gdje se ženstveno, kao ono potisnuto i odsutno, naknadno vraća u kulturno prihvatljivijem obliku kao zrcalni odraz muškog Drugog.

Psihoanalitički orijentirana feministička kritika razlike ženskog govora i pisma smješta u prostor morfologije i fiziologije uma, a njihovu produkciju i cjelokupan kreativni proces $\mathrm{u}$ velikoj mjeri podređuje spolnim i rodnim obilježjima. Lingvistika se, na taj način, stapa $\mathrm{s}$ biologijom, dok se anatomija pisma sagledava iz perspektive anatomije tijela.

Takvi teorijski zahvati nalažu i određen stupanj revizije Freudovih i Lacanovih tekstova, promatranje psihoanalitičkih zakona iz drugačijeg, ginocentričnog, rakursa. U tom smislu, neke autorice spominju spisateljsko pero kao patrijarhalno obilježen falusni simbol kojim se muška kulturološka dominacija uvijek iznova potvrđuje, a ženska ruka, koja tim istim perom nastoji upravljati i postići neke različite, sebi svojstvene ženske i ženstvene kriterije, opisuje se kao dio tijela u neprekidnom konfliktu s nadređenim faličkim strukturama. ${ }^{53}$. U potrazi za organskim izvorom iz kojeg ženskost i ženstvenost crpe svoju stvaralačku energiju, autori skloniji nešto radikalnijem pristupu govore o mokraćnom mjehuru kao mogućem kandidatu, koji, poradi nešto ekstenzivnijih mjera u žena $i$ činjenice da je u njih sam čin mokrenja snažniji i prodorniji, predstavlja sponu između spolnog i jezičnog, odnosno pod utjecajem specifičnih fizioloških procesa čini ženski jezik fluidnijim, fleksibilnijim i silovitijim. ${ }^{54}$

U zbirci tekstova Ce sexe qui n'en est pas un (Taj spol koji nije jedan) iz 1977., Irigaray razmatra žensku morfologiju i ženski erotizam, te ih pokušava dovesti u vezu sa ženskim

\footnotetext{
${ }^{53}$ Gilbert i Gubar (1979, p. 6-7).

${ }^{54}$ Ovdje Elaine Showalter opisuje radikalne teze Theodora Reika (Showalter 1981, p. 194).
} 
načinom poimanja i izražavanja emocija. Prema njezinom mišljenju, između ženske morfologije i ženske psihologije postoji značajna analogija, gotovo nedokučiva muškom jedinstvenom, monolitnom i krutom načinu percepiranja i shvaćanja stvarnosti. Ženska je morfologija, tvrdi Irigaray, raznolika i mnogostruka, ženski spol nije jedan, a zbog činjenice da su ženski spolni organi sastavljeni od mnogo različitih dijelova (stidnih usana, klitorisa, vagine, maternice, grudiju), ženski je užitak (jouissance) također mnogostruk i nedjeljiv: „,žena se neprestano dodiruje, a da joj to nitko ne može zabraniti, stoga što je njezino spolovilo sastavljeno od dviju usana koje neprekidno međusobno opće“ (1977, p. 24). Ženstvenost daje prednost dodiru, dok muževnost prednost daje vizualnom. Ženska je erotika taktilne prirode i karakteriziraju je duboka intimna povezanost s vlastitim tijelom, kao i s tijelom koje joj je blizu: ,prevladavanje pogleda, razlikovanje i individualizacija oblika osobito su strani ženskoj erotici. Žena više uživa u dodiru nego u vidu““ (p. 25). U eseju pod naslovom La méchanique des fluides (Mehanika fluida) Irigaray još jednom analogijom dovodi u vezu ženstvenost, kao prirodno tekuće svojstvo, odnosno muževnost, kao krutu i solidnu tvar, navodeći kako falokratska znanost stoljećima nailazi na brojne poteškoće u razumijevanju zakona fluida, upravo na jednak način kao u razumijevanju ženskog spola. Ženski se jezik, tvrdi Irigaray, ponaša poput fluida; opire se konačnoj fiksaciji i značenju, promijenjivog je oblika, odnosno, konačni oblik postiže ovisno o kontekstu unutar kojeg se nalazi:

\footnotetext{
Ona je neprekidna, stlačiva, može se proširiti, viskozna je, provodi struju, difuzna je... nikada ne završava, istodobno je moćna i nemoćna jer se opire onome što je brojivo, pronalazi užitak i pati zbog svoje preosjetljivosti na pritisak; mijenja se $-\mathrm{u}$ volumenu ili snazi, primjerice - ovisno o temperaturi, njezinu fizičku stvarnost određuje trenje između dviju beskrajno susjednih sila - dinamika blizine, a ne vlasništva. (p. 109-110)
}

Ženstvenost je pluralna i inkluzivna ${ }^{55}$, ona ne žudi posjedovati, već biti posjedovana, a upravo je takav, ističe Irigaray, i specifičan ženski govor, le parler femme (womanspeak). Iako le parler femme autorica s teškoćom definira: ,jednostavno vam ne mogu dati objašnjenje ženskog govora, njime se govori, ne može ga se metagovoriti““ (p. 141), koristeći se već spomenutom analogijom između ženske morfologije i ženske psihologije, odnosno taktilne

\footnotetext{
55 Žena ne mora birati između klitoralnoga i vaginalnoga užitka, kako je Freud tvrdio, već može jednostavno uživati u oba.
} 
percepcije, Irigaray govori o intimnoj povezanosti jezika s osjetom dodira: „taj stil ne daje prednost pogledu nego sve figure vraća njihovu taktilnom rođenju“, te njegovoj sposobnosti da poput fluida izmiče patrijarhalnoj logici „uvijek fluidna [...] njezin se stil odupire svim čvrsto ustanovljenim formama“" (p. 76).

Ženski je jezik u neprekidnom pokretu, baš kao i u žene, njegovi se dijelovi neprestano dodiruju. Njega ne pokreću unaprijed pripremljeni kodovi ili obrasci, već osjećaj bliskosti s vlastitom nutrinom i vlastitim tijelom. Kada žena progovara, ona kazuje i o „onom drugom“ unutar sebe. I upravo je to razlog, tvrdi Irigaray, zbog kojeg je često doživljena kao temperamentna, nemirna, nerazumna, pa čak i ćudljiva (p. 28). No, da bi ženu „čuli“, napominje Irigaray, postojeće falocentrične diskurzivne metode moraju u potpunosti biti odbačene, a prihvaćen jedan nov, difuzan i mnogostruk, način obraćanja, jezik kojim se žena „rasipa na sve strane“ (p. 28), jezik kojim se žena uvijek iznova i neprekidno dodiruje, jezik koji, tražeći potpunu dekonstrukciju, neutralizaciju i odvajanje od ekonomije logosa, u potpunosti zaobilazi imaginaran prostor muškarca.

U knjizi naslovljenoj Je, Tu, Nous. Pour une culture de la différence (Ja, Ti, Mi. Za kulturu razlike) iz 1990. godine Irigaray detaljno izlaže svoju teoriju odnosa spolnih i jezičnih rodova, te razmatra podrijetlo, utjecaj i osobitosti ženskog, kao i muškog diskursa.

Nakon dugogodišnjih istraživanja, ${ }^{56}$ autorica potvrđuje i proširuje vlastite teze o spolnosti u jeziku, te im pridodaje još jedno snažno znanstveno uporište. Naime, istraživanja pokazuju kako muškarci mnogo češće zauzimaju subjektnu poziciju u jeziku, dok su poteškoće u samoraprezentaciji i iskazivanju odnosa unutarnjeg i vanjskog svijeta u žena mnogo izraženije, tako da čak ni uporaba prvog lica nije nužno vezana uz njihov ženski identitet (1990, p. 7). Također, u muškaraca i žena očita je različita uporaba određenih gramatičkih kategorija, kao i različit odabir pojedinih leksema ${ }^{57}$ (p. 25-26). Irigaray još jednom potvrđuje kako žene, za razliku od muškaraca, vlastiti glas snažno seksualiziraju, povezuju ga s tijelom, obraćajući se uvijek spolno određenim sugovornicima, te dodaje kako žene češće opisuju svijet konkretnim imenima i osobinama, za razliku od muškaraca, čiji svijet postaje skup apstraktnih neživih stvari, integriranih u svijet subjekta (p. 27).

\footnotetext{
56 Sexes et Genres à travers les langues (Spolovi $i$ rodovi u pojedinim jezicima), zbornik istraživanja o francuskom, engleskom i talijanskom jeziku.

${ }^{57}$ U muškom slučaju često s nijansiranim stupnjevima dvoznačnosti (Irigaray 1990, p. 26).
} 
Odnos muškog subjekta u govoru i vlastitog tijela, kao i drugih tijela u blizini, prema Irigaray vrlo je posredan (p. 28). Ipak, zaključuje Irigaray, usprkos ženskom prirodnom, spontanom i neposrednom kontaktu s okolinom, u govoru žene otkriva se slika vanjskoga svijeta kao skupa pojmova i pojava koji pripadaju svijetu drugoga. U tom smislu, iako žene zadržavaju blizak odnos sa stvarnom okolinom, one je i dalje ne subjektiviziraju kao vlastitu, o čemu svjedoči i učestalija uporaba pridjeva nasuprot rjeđoj uporabi predikata unutar ženskoga diskursa, odnosno činjenica da žene svijet više osjećaju i primaju u sebe, no što osjećaju da na njega mogu istinski djelovati (p. 29).

Promatrajući ženskost kao umjetnički, odnosno jezični stil, Nadežda Čačinovič navodi kako Irigaray zauzima poprilično radikalnu poziciju, zagovarajući različitost, odvojenost, esencijalizam, pa čak i svojevrstan biologijski determinizam (Čačinovič 2000, p. 119).

Da, Irigaray prikazuje spolnost u jeziku kao znanstvenu datost. Za nju svaki pokušaj neutralizacije i/ili eliminacije spolnosti unutar govora i pisma znači ,trajno održavanje pseudo-neutralnosti zakona i tradicije koje privilegiraju muške genealogije i njihove logičke kodove“ (Irigaray 1990, p. 41). Ipak, za nju lingvistički spolovi i rodovi nisu isključivo biološki fenomeni, već i posljedice međuljudskih, društvenih, utjecaja. Jezik jest proizvod sedimentacija nekih prijašnjih jezika, nekih prošlih razdoblja, a svako razdoblje i svaka kultura nameće nove vlastite zakonitosti i običaje. Prema Irigaray, razlike u diskursu među spolovima nepobitna su činjenica, no one su mješovit rezultat utjecaja biologije i kulture, od kojih se, kroz povijest, uvijek jedan pokaže manje ili više otporan od onog drugog. 


\section{I. II. Hélène Cixous}

Rođena 1938. u kolonijalnom Alžiru, židovskog podrijetla, kao i Jacques Derrida, Hélène Cixous jedna je od najznačajnijih i najutjecajnijih suvremenih francuskih intelektualki. Oslanjajući se na poststrukturalizam i Derridaovu dekonstrukciju, između 1975. i 1977. godine Cixous proizvodi čitav niz teorijskih i poluteorijskih tekstova kojima istražuje odnose ženskog, ženstvenog i tekstualnog, odnosno propituje termin écriture feminine ${ }^{58}$ (ženstveno pisanje). Eseje ovog razdoblja moguće je, kako formalno tako i sadržajno, povezati pojmom koji Cixous preuzima iz dekonstrukcijske kritike, a to je différance (razlika, odgoda). Pojam različitosti ženskog pisma (différance), u odnosu na spol, kao i teza o heterogenoj različitosti muževnog i ženstvenog unutar tekstualnog, temeljna su razmatranja ovih znanstvenih eseja. Iako su njezina privrženost ženskom pokretu te uvijek prisutna kritika patrijarhalnog sustava mišljenja neupitne, Cixous, baš kao i Kristeva, odbija sebe definirati feministicom i to ponajprije jer smatra kako se feminizam temelji isključivo na zamjeni teza ${ }^{59}$, a ne na oslobođenju i afirmaciji ženskog, odnosno ženstvenog.

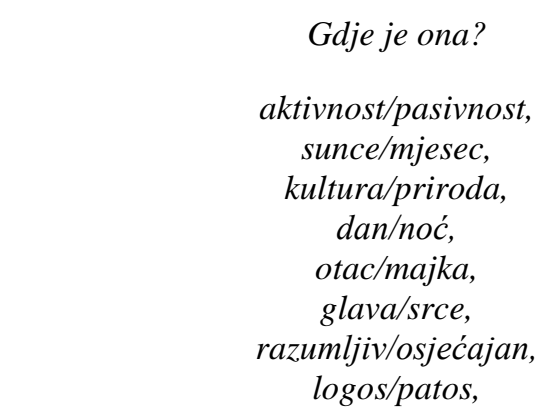

Forma, konveksnost, etapa, napredak, izvor. Materija, konkavnost, osnova - koja podržava etapu. Muškarac Žena'.

(Cixous 1975a, p. 258)

Ovaj popis binarnih opozicija, kojim započinje esej Sorties, Cixous koristi kako bi objasnila temeljni princip patrijarhalnog vrijednosnog sustava, princip falocentrične zapadnjačke logike binarnih opreka, unutar koje se svaka opreka može analizirati kao hijerarhijski nadređena, odnosno podređena: „razlikovnosti koje su hijerarhizirane“ (1975a, p. 258). Binarne su opreke

\footnotetext{
${ }^{58}$ Tematika koja pripadnice francuske feminističke teorije istovremeno razdvaja i spaja.

${ }^{59}$ Opresivna mreža patrijarhalne ideološke moći zamijenjena je zahtjevom za matrijarhalnim sustavom mišljenja.
} 
$\mathrm{u}$ temeljima strukturalističke teorije. Strukturalisti, poput Greimasa u Strukturalnoj semantici $^{60}$ (1966), smatraju da se značenje proizvodi unutar binarnih opreka, odnosno da se u oprekama poput aktivno/pasivno i muževno/ženstveno postiže značenje datih pojmova, dakle, kroz njihov strukturalni odnos prema onom drugom. U tom bi slučaju muževno bilo beznačajno bez ženstvenog, aktivno ne bi imalo smisla bez pasivnog i obrnuto. I sve bi se, prema mišljenju strukturalista, proizvodilo na takav način. Naravno da je očit protuargument ovakvoj teoriji komparacija pridjeva (npr. dobar, bolji, najbolji). Poststrukturalizam, odnosno dekonstrukcijska kritika ${ }^{61}$, na čelu s Jacquesom Derridaom, sustav binarnih opreka nastoji poništiti, detektirajući ga kao logocentričnog i kao falocentričnog, odnosno kao falogocentričnog ${ }^{62}$, kao sustav koji privilegira onog koji je hijerarhijski nadređen, onog koji posjeduje jednu i jedinu apsolutnu istinu: „Teorija kulture, društva, skup simboličkoga sistema - umjetnost, religija, porodica, jezik - sve razrađuje isti sistem [...] Hijerarhizacija uvijek podvrgava cjelokupnu konceptualnu organizaciju muškarca“ (Cixous 1975a, p. 259). Cixous ističe kako se svaka navedena opreka može promatrati kao statična hijerarhija unutar koje se ono ženstveno uvijek označava kao inherentno negativno, pasivno, nemoćno, inferiorno ili pak nerazumljivo. Strukturalističkoj teoriji binarnih opreka Cixous suprostavlja Derridaov koncept heterogene razlike (différance). Prema Derridau (2007) ${ }^{63}$, značenje se ne proizvodi unutar zatvorenog matriksa ${ }^{64}$ binarnih opreka, već se ono oslobađa beskonačnim

\footnotetext{
${ }^{60}$ Greimas, A.J. (1969) Sémantique structurale: Recherche de Méthode. Paris: Larousse.

${ }^{61}$ Dekonstrukcijska je metoda u mnogočemu slična Freudovoj psihoanalitičkoj. Radi se o dvjema vrstama prodora; prodora u jezik i prodora u nesvjesno, te njihovom oslobođenju od represije falogocentrizma, odnosno podsvjesno i nesvjesno potisnutog materijala. Metodom dekonstrukcije dolazi do fragmentacije, do raspadanja matriksa, što omogućuje oslobođenje od okova čula i uma, od pretpostavljenih obrazaca. Nihilistički nastrojen, Derrida svoju dekonstrukcijsku metodu vidi kao pogled u budućnost, za razliku od strukturalista, za koje smatra da se bore s okovima prošlosti: „strukturalistički je svijet tout court kao promišljanje prošlosti [...] razmišljanje o svršenom, o uspostavljenom, o izgrađenom“ (Derrida 2007, p. 3). Optužujući Zapad za štovanje kulta lažnih ideologija, jer „povijest metafizike, kao i povijest Zapada, povijest su metafora i metonimija“ (p. 298), kompleksnim epistemiološkim pristupom Derrida u potpunosti dekonstruira tradicionalno metafizičko shvaćanje identiteta i totaliteta, kao ontološki uvijek prisutne stvarnosti, te uspostavlja neku vrstu kulturnog relativizma. Čar Derridaove dekonstrukcije krije se u sposobnosti rušenja metanarativa i izlaska iz svijeta matriksa, u pronalasku novog čovjeka, oslobođenog od autoriteta, normi i kulturnih ograničenja.
}

${ }^{62}$ Termin koji je uveo upravo Jacques Derrida, a označava spoj zapadnjačkog privilegiranja logosa (riječi), kao metafizičke prisutnosti, te falusa kao izvora i simbola moći.

${ }^{63}$ Prvo izdanje knjige Pisanje i razlika datira iz 1967.

${ }^{64}$ Termin koji proizlazi iz kvantne fizike Davida Bohma, odnosno njegove ideje holografskog svemira. Matriks označava sav materijalan i fizički svijet koji čula mogu percipirati. Za njega su vezane kategorije vremena $i$ prostora, budućnosti i prošlosti. Kvantna ga fizika definira kao iluziju percepcija naših čula i našeg uma, a glavna mu je osobina dualnost, sustav binarnih opozicija između kojih postoji konstantna borba, što čovjeka, koji prirodno teži ka savršenstvu i pronalasku istine, osuđuje na vječnu životnu patnju i nemir. 
procesom igre označitelja. Kao argument vlastitim tvrdnjama Derrida postavlja primjer Saussureovog koncepta fonema, najmanje razlikovne jedinice jezika. Za fonem se, ističe Derrida, nipošto ne može tvrditi da postiže značenje svojom binarnom oprekom, jer sami po sebi fonemi ' $p$ ', ' $k$ ' ili ' $h$ ' ne znače ništa. Kada bismo foneme na taj način izolirali i postavili u proces binarnih opreka, ne bismo uspostavili konačno značenje unutar jezika kao sustava znakova. Fonemi, međutim, sposobnost označivanja ${ }^{65}$ postižu uspostavljanjem razlikovnih odnosa $^{66}$. Različito značenje fonema ' $b$ ', ' $k$ ' ili ' $h$ ' ostvaruje se tek u kontekstu ostalih fonema, odnosno, fonem svoju bit ostvaruje tek u riječima i rečenicama, poput 'bat', 'kat' ili 'hat'. Također, prema Derridau, ne postoji transcendentalno označeno, kojim se proces označivanja može konačno i zauvijek zatvoriti, upravo jer pojmovi, elementi sustava, sami po sebi ne znače ništa, ne posjeduju nikakvu bit i svrhu izvan sustava: „ne postoji transcendentalno ili povlašteno označeno, te samim tim područje i igra značenja više nemaju granica“" (Derrida 2007, p. 299). I to je osnovno načelo Derridaove teorije o razlici, kao one koja priskrbljuje značenje, inzistirajući na sufiksu '-ance' (différance), kojim biva označena pisana riječ i koja se u francuskom jeziku razlikuje od '-ence' (différence), kojom Derrida označava govorenu riječ. I dok drugi termin, différence, označava isključivo različitost, prvi označava razliku u smislu odgode, odnosno odgađanja kao procesa koji se opire konačnoj fiksaciji. Radi se o beskonačnom procesu razlikovanja kojim se ostvaruju vremenska i prostorna otvorenost teksta, sloboda od okova konačnog označivanja. Derrida inzistira na ovom razlikovanju pisane i govorene riječi, tvrdeći kako je zapadna metafizika oduvijek sklonija dati prednost govorenoj riječi i to zato jer pretpostavlja prisutnost subjekta koji govori, te je u tom smislu autentičnija. Ta metafizika prisutnosti ${ }^{67}$, kako je Derrida naziva (p. 299), značenje smatra potpuno prisutnim u svijetu: ,determinacija bitka kao prisutnosti u svakom smislu te riječi“ (p. 298). Nasuprot takvoj idealističkoj diskriminaciji govorene riječi, kao mjestu otuđenja, Derrida pisanoj riječi dodjeljuje fluktuacijsko, pokretljivo svojstvo. Problematiku subjekta kao jedinog autentičnog izvora vlastitog diskursa Derrida vidi i u tradicionalističkom shvaćanju autora, kojim se sloboda jezika, kao i mogućnost sljedećeg označivanja, u

\footnotetext{
${ }^{65}$ Franc. signification, pojam kojim se u semiotici naziva odnos između znaka i predmeta (referenta).

${ }^{66}$ Lacanova je teorija pokazala kako označitelj (materijalni dio znaka) može „kliziti“ u odnosu na označeno (pojmovna reprezentacija označitelja) tako da je pojam referenta (kognitivne razine pojma) doveden u pitanje.

${ }^{67}$ Franc. la présence može značiti prisutnost, nazočnost, ali i sabranost (Putanec, 2000).
} 
potpunosti zatvara. Stoga Derridaove analize, rušeći monolitni sustav velikih metanarativa ${ }^{68}$, tekstualan prostor do kraja rastvaraju i provaljuju $\mathrm{u}$ ono što Cixous smatra tamnicom patrijarhalnog jezika.

U Meduzinom smijehu ${ }^{69}$, Cixous razmatra pojmove ženstveno, muževno te biseksualno unutar tekstualnog. Prema mišljenju Cixous, ženstven je onaj tekst koji „radi na razlici“ (1977a, p. 480), na rušenju sustava binarnih opreka. On je neka vrsta antimetafizičke pobune koja rastvara zagušljivi prostor jezičnog matriksa te oslobađa tekst okova zapadnjačke falogocentrične paradigme. Govoreći o muževnosti i ženstvenosti unutar tekstualnog prostora, Cixous ističe kako se radi isključivo o libidnoj ženstvenosti, odnosno muževnosti koju, neovisno o spolu autora, unutar nekog teksta možemo odgonetnuti. Dakle, ovdje se ne radi o empirijskom spolu autora, već isključivo o tendenciji pisanja:

\begin{abstract}
Mora se jako paziti kada se radi sa ženskim pisanjem da se ne upadne u zamku imena: to što je potpisan ženskim imenom, tekst ne čini nužno ženstvenim. Moglo bi jednako tako biti riječi o muževnom pisanju, i obrnuto, sama činjenica da je tekst potpisan muškim imenom, ne isključuje ženstvenost. (Cixous 1981, p. 52)
\end{abstract}

Teza o mogućem muževnom pismu ženskih autorica, odnosno ženstvenom pismu muških autora, govori o Cixousinom konceptu biseksualne prirode ljudskih bića. Iako se taj koncept uvelike razlikuje od onog tradicionalističkog shvaćanja biseksualnosti, u smislu jednog jedinstvenog bića sastavljenog od dvije homogene polovice. Protiveći se takvoj definiciji, Cixous govori o tzv. drugoj biseksualnosti (Autre Bisexualité) ${ }^{70}$. Prema njezinom mišljenju, razlog homogenog koncepta biseksualnosti muški je strah od Drugoga, od kastracije, od moguće infekcije ženskim. Takvom „falocentričnom viđenju seksualnosti“ (1975b, p. 254) Cixous suprotstavlja mnogostruku i varijabilnu biseksualnost, onu koja „ne isključuje niti jedan od spolova, onu koja razlike ne poništava, već ih umnožuje“ (p. 254). U takvoj

${ }^{68}$ Metanarativ označava sveobuhvatnu interpretacijsku shemu koja oblikuje i ograničava interpretacijske strategije pojedinca. Prema Jean-Françoisu Lyotardu, prosvjetiteljstvo (vjera u moć razuma) i znanost (pobjeda znanja) dvije su velike naracije moderniteta. Osnovna značajka postmoderniteta je gubitak vjere u metanaracije, tj. raspad „velikih priča“ te nov i multiperspektivan pogled na svijet.

${ }^{69} \mathrm{U}$ grčkoj je mitologiji Meduza prikazana kao dugokoso žensko čudovište koje pogledom pretvara muškarce u kamen. Prema legendi, Perzej je Meduzi uspio odrubiti glavu, što je Freud protumačio kao klasičan kastracijski simbol. Govoreći o Meduzinom smijehu, Cixous zapravo aludira na Freudov slučaj Dora, te Lacanov esej Značenje Falusa, odnosno na čitav falogocentričan sustav mišljenja koji ženu definira kao „kastriranog muškarca“ (Cixous 1975b, p. 243).

${ }^{70}$ Derrida govori o Drugom (Autre) kao onom koji otvara prostor transcendencije i oslobađa od ralja metafizike (Derrida, 2007 »Nasilje i metafizika« u: Pisanje i razlika, p. 87). 
biseksualnosti žena i muškarac stvorili su paralelan svemir drugog spola u kojem postoje dvije različite lokacije sebstva (répéperage en soi), njegovo i njezino (p. 254) ${ }^{71}$. No, Cixous napominje kako su žene, čak i u pisanju, sklonije biseksualnosti i to poglavito iz dva razloga. Prvi se tiče povijesno-kulturnih okolnosti koje su muškarca dovele u položaj onog koji „vlastitu faličku monoseksualnost mora održavati uvijek u punoj snazi“ (p. 254), a drugi govori o problematici edipskog sukoba, odnosno činjenici da se muškarac, potiskujući majku, konstantno i uporno brani od vlastitih libidnih poriva, što žena ipak ne čini. Iz svega navedenog, razvidno je da Cixous, govoreći o biseksualnom pisanju, najčešće zapravo govori o prirodi ženskog pisanja. ${ }^{72}$

Žensko je pismo, prema mišljenju Cixous, prostor užitka (jouissance) i prostor razmjene s Drugim (Autre). Ono je uvijek, u nekom smislu, libidan čin koji označava ,artikulaciju žudnje u jeziku“ (Moi 2007, p. 176). Njime seksualno prodire u tekstualno, stapajući se i postajući jedno. Analogiju seksualnog čina i čina pisanja u žene povezuje element vode. Za Cixous, ali i za sve mitologe, voda je najženstveniji element. Ona podsjeća na sigurnost majčine utrobe, prostor unutar kojeg se osjećamo sigurno i slobodno. Taj beskonačan imaginaran prostor, ispunjen fluidom koji nas spaja s ostatkom svijeta, označava erotogenost heterogenog:

\begin{abstract}
Mi smo sami more, pijesak, koralji, morska trava, plaže, plime, plivači, djeca, valovi... Heterogeni, da. U svoju radosnu korist ona je erogena; ona je erotogenost heterogenoga: plivačica nošena zrakom, u letu, ona se ne drži sebe; ona je raspršena, čudesna, zapanjujuća, željna drugih i sposobna biti drugima, željna druge žene kojom će biti, druge žene kojom nije, njega, tebe. (Cixous 1975b, p. 260)
\end{abstract}

U takvoj panteističkoj, oceanskoj predodžbi ženskog tekstualnog prostora, u kojem sve teče i prelijeva se u jedno, odjekuju zvuci prajezika: ,jezika tisuću jezika, jezika koji ne poznaje ni zatvorenost ni smrt, jezika koji pušta da drugi jezik govori““ (1975c, p. 162). Taj prvi glas, glas prve pjesme koju je nekad davno čula, glas je prve žene, prve majke ${ }^{73}$. Taj nježan, a istodobno i moćan, prajezik koji, ističe Cixous, odjekuje u svim ženskim tekstovima lociran je unutar

\footnotetext{
${ }^{71}$ Iako se Cixous nikada izravno ne poziva na Junga, u Meduzinom smijehu, govoreći o heterogenom obliku biseksualnosti te konceptu dvostrukog sebstva, utjecaj njegove teorije o animusu i animi više je nego očit.

${ }^{72}$ Iako Cixous navodi kako u nekim iznimkama muškarci raskidaju vezu s vlastitom monoseksualnošću, no to su, tvrdi, izolirani slučajevi (p. 254).

${ }^{73}$ Još jedna očita povezanost Cixous i Junga, odnosno njegove teorije o kolektivno-nesvjesnom. Predodžba glasa prve žene, prve majke, kao glasa koji izvire iz najdubljih slojeva psihe, analogna je Jungovoj predodžbi arhetipa Velike Majke.
} 
lacanovskog imaginarnog, unutar prostora u kojem sve binarne opreke bivaju poništene - jer majka i dijete su jedno. Svevremenski jezik meda i mlijeka ne poznaje Zakon. U prededipskom prostoru, obilježenom apsolutnom slobodom, nasilni jezični zakoni i kruta sintaksa ne pronalaze svoj put: „Glas, pjesma prije Zakona, prije daha (le souffle), rascijepljen je simboličkim, ponovno prilagođen jeziku pod autoritetom koji razdvaja. Najdublja, najstarija vizitacija, najdostojnija obožavanja“ (1975c, p. 172). Taj kozmički prostor vječnosti, koji nema svoj početak i kraj ${ }^{74}$, u potpunosti je ispunjen glasom, onim glasom koji izvire iz najdubljih slojeva ženske psihe, glasom majke. I zato je, prema Cixous, žena koja piše strahovito moćna - njezina puissance féminine (ženska moć) potječe izravno iz glasa iskonske žene. Cixous ističe kako je žensko pisanje u naravi govorni čin, te se ženstvenost u pisanju može upravo raspoznati kao davanje prednosti glasu: „pisanje i glas... isprepleteni su“ (1975c, p. 170). Žena koja govori u cijelosti je svoj glas, „ona fizički materijalizira ono o čemu razmišlja, označava to svojim tijelom“ (1975b, p. 251; 1975c, p. 170). Drugim riječima, žena je potpuno i fizički prisutna u svome glasu, a pisanje je, u tom smislu, izravan i samoidentičan nastavak govornog čina.

U Cixousinoj se teoriji o ženskom pismu prepliću dvije razine, dva prostora pisanja: prededipsko i edipsko, odnosno Lacanovim rječnikom, imaginarno i simboličko. Prvi je prostor, obilježen majčinim glasom te mirisom meda i mlijeka, mitski prostor majčine utrobe koji zaštićuje i spaja, a Cixous ga u kleininskom stilu ${ }^{75}$ opisuje kao prostor gotovo oralnog odnosa prema tekstu: „Jela sam tekstove, sisala, lizala, ljubila ih, ja sam nebrojeno dijete njihovih mnoštvenosti“ (1977b, p. 19). Taj početni osjećaj potpune sigurnosti odjednom razbija Zakon svijeta simboličkog. U tom se trenutku ženski odnos prema jeziku, koji je sada već dio falogocentričnog poretka, u potpunosti mijenja. Nužnost pokoravanja faličkoj vladavini iz žene crpi osjećaje koje još ni sama ne raspoznaje. Osjećaj žudnje (le désir), koji nije u stanju svjesno kontrolirati, potpuno je obuzima. Pisanje od nje traži priču, vrijeme i oblik, čemu ona, nalazeći se još uvijek u sigurnosti imaginarnog prostora, uspješno odolijeva. Osjećajući strast prema nepoznatom, istovremeno se guši u osjećaju krivnje jer dopušta da se nasilno pokoravanje Falusu dogodi. No, kao i kod nasilnog, prisilnog, seksualnog odnosa, o kojem žene ponekad maštaju i sanjaju, tako i kod prisile pisanja, usprkos nevoljkosti

\footnotetext{
${ }^{74} \mathrm{O}$ tome podrobnije piše Julia Kristeva u članku Women's Time (Žensko Vrijeme).

75 Tekst kao metafora majčine bradavice, prededipskog penisa.
} 
pristupanja u falusni jezični prostor, žena ipak osjeća dozu tajne opčinjenosti tim neodoljivim prizvukom pisanog, neodoljivim dahom (le souffle):

\footnotetext{
Zato što je bio tako snažan i tako bijesan, voljela sam taj dah i bojala ga se. Jednoga se jutra naći uzdignutom, zgrabljenom s tla, bačenom u zrak. Iznenaditi se. Pronaći u sebi mogućnost neočekivanog. Zaspati kao miš i probuditi se kao orao! Kakav ushit! Kakav užas. A nisam imala veze s tim, nisam si mogla pomoći. (Cixous 1977b, p. 18)
}

Nakon što je prekoračila simbolički poredak i ovladala jezikom, žena se osjeća jačom i moćnijom. Integrirajući u sebe moć Falusa, napustila je osjećaj krivnje i poput „orla“ izdignula se iznad prostora vremena i razuma.

Žensko pisanje kao vraćanje tijelu te žensko pisanje kao konačna inkarnacija žudnje (le désir), temeljne su dogme Cixousine teorije. Vizija ženske tekstualne kreativnosti, kao trenutka potpunog oslobođenja od okova patrijarhalnog, nakon Hélène Cixous poprima jasniji oblik. 


\title{
II. I. III. Julia Kristeva
}

Francuskinja bugarskog podrijetla, općepoznatog visokointelektualnog diskurzivnog stila, karijeru je započela šezdesetih kao lingvistica. Sedamdesetih godina paralelno raste njezin interes za feministička pitanja i psihoanalizu i od tada je uglavnom koncentrirana na pitanja spolnosti i ženstvenosti. Na njezin rad utječe lijeva politička orijentacija, no kako se ona kreće od ranog pristajanja uz marksizam i maoizam, pa sve do neke vrste liberalnoga kapitalizma američkog tipa, tako se i njezini raniji radovi uvelike razlikuju od onih kasnijih. Baš kao Jacques Derrida i Hélène Cixous, Julia Kristeva odbija prihvatiti temelje moderne lingvistike koji jezik prikazuju kao monolitni sustav znakova, kompaktne i homogene strukture. U eseju The ethics of linguistics (Etika lingvistike) Kristeva se obrušuje na moderne gramatičare, upozoravajući ih na logičke, etičke i političke pogreške njihovih teorija. Smatrajući kako su se vremena promijenila, kako lingvistika očito ne prati napredak pojedinca i društva, te kako je nužno pomaknuti se od jednoličnog i statičnog sustava promišljanja $\mathrm{k}$ jednom novom višeperspektivnom i raznolikom prostoru djelovanja, osuđuje modernu lingvističku znanost kao odviše autoritarnu i opresivnu te istovremeno zahtijeva svojevrstan izlaz iz saussureovskog koncepta jezika:

\begin{abstract}
Kao čuvari represije i racionalni tumači društvenoga ugovora u njegovu najčvršćem supstratu (diskursu), lingvisti predstavljaju posljednju fazu stoičke tradicije. Epistemologija u podtekstu lingvistike i kognitivni procesi koji iz nje proizlaze (strukturalizam, primjerice), premda tvore branik od iracionalne destrukcije i sociološkoga dogmatizma, čine se nepopravljivo zastarjelima kada ih se suoči sa suvremenim mutacijama subjekta i društva. (Kristeva 1980, p. 24)
\end{abstract}

Pad dogmi moderne lingvistike Kristeva proriče putevima Marxa, Freuda i Nietzschea, nakon kojih se predodžba subjekta i pozicija ega u potpunosti mijenjaju, odnosno iz pozicije konačno definiranog transcendentalnog subjekta koji „govori, dakle jest“ prelazi se u poziciju decentriranog, rascijepljenog subjekta koji „govori, dakle nije“, odnosno lacanovskim

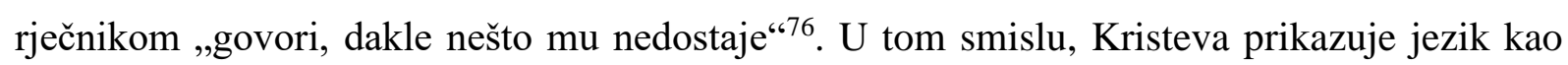
otvoren sustav označivanja, prostor u neprekidnom procesu oblikovanja i traženja onog što

\footnotetext{
${ }^{76}$ Kada dijete nauči reći ,ja sam“ i to razlikovati od „„i si“ ili „oni su“, znak je da je nastupio proces napuštanja imaginarnog poretka, pri čemu dolazi do primarnog potiskivanja i stvaranja nesvjesnog, te zauzimanja pozicije unutar simboličkog poretka, koji od njega zahtijeva odustajanje od polaganja prava na imaginarni identitet, kako s majkom, tako i s ostatkom svijeta. Stoga subjekt koji govori ,ja sam“ zapravo kazuje ,ja sam onaj koji je nešto izgubio/la“, odnosno ,ja sam ono što nisam“, a samo njegovo postojanje ostvareno je potiskivanjem žudnje za izgubljenom majkom, dakle, postojanje jest znak gubitka, nečeg čega više nema (Recalcati 2012, p. 340-398).
} 
nedostaje. Ta „heterogena destruktivna uzročnost““ (Kristeva 1980, p. 27) dovodi do poništenja arhaičnog shvaćanja jezika kao statičnog sustava znakova i otvara prostor diskursu kao novom mjestu subjekta koji kazuje.

Odustajanje od lingvistike usmjerene na sustav stabilnog znakovlja dovodi u pitanje i Kristevin stav o spolnim razlikama u upotrebi jezika. Naime, prema mišljenju Kristeve, označiti nešto kao muževno ili ženstveno, značilo bi zatvoriti razlikovno polje značenja, prvenstveno između dijelova navedenih binarnih opreka, determinirati navedene kvalitete kao stabilne i nepromjenjive ontološke biti, kao potpune i apsolutne prisutnosti ${ }^{77}$. Za razliku od strukturalista, koji prepoznaju jedan, jedinstven i univerzalan jezik (langue), Kristeva jezik smješta između subjekata koji govore, te na taj način sugerira proučavanje jezičnih strategija u mnogo širim okvirima - u okvirima diskursa, odnosno konteksta. U knjizi Marksizam i filozofija jezika ${ }^{78}$ Mihail Bahtin ističe kako suvremena lingvistika mora nadići nepovredivu barijeru rečenice te skokom iz prostora sintakse zakoračiti u prostor diskursa: „lingvističko mišljenje ne ide dalje od elemenata monološkoga iskaza. Struktura složene rečenice (perioda) - to je najdalje granica lingvističkoga dosega [...] lingvistici nedostaje bilo kakav pristup kompoziciji cjeline [...] Jedino skokom iz sintakse možemo dosegnuti probleme kompozicije“ (Bahtin 1980, p. 78-79). I Bahtin i Kristeva nastoje u potpunosti neutralizirati i dekonstruirati stare disciplinarne barijere moderne lingvistike, stvarajući istodobno vlastitu teoriju - teoriju diskursa, odnosno semiotiku. Krećući se putanjom Derridaove dekonstrukcije, koja jezik otvara i raščlanjuje, upisujući tako beskonačan broj mogućih kombinacija, ova nova suvremena teorija teksta, semiotika, u svrhu razumijevanja bilo koje vrste jezičnih iskaza predlaže istraživanje konteksta, kao i interteksta ${ }^{79}$. Vraćajući se na problem proučavanja spolnih razlika u jeziku, očito je da, prema mišljenju Kristeve, eventualne analize izoliranih dijelova teksta (rečenice) $)^{80}$ neće polučiti nikakve rezultate. Sve u svemu, bilo kakav semiotički trag, poput mimike i motoričkih gesti, intonacije i interpunkcijskih stanki, kao i fonetskih te leksičkih predispozicija, postat će relevantni tek u sklopu cjelokupnog iskaza koji

\footnotetext{
77 Čemu se također protivi, kako je u prethodnom poglavlju već rečeno, dekonstrukcijska kritika Jacquesa Derridaa.

${ }^{78}$ Prvo izdanje knjige objavljeno je 1929. godine.

${ }^{79}$ Pojam koji je uvela Julia Kristeva, a odnosi se na premetanje jednog ili više sustava znakova u neki drugi. Intertekstualnost, prodiranje sintagmatskih i paradigmatskih silnica, glavno je obilježje postmoderne književnosti.

${ }^{80}$ Kao primjerice teorija Virginije Woolf o postojanju tzv. ženske rečenice.
} 
implicira ideološku, sociološku, psihološku te psihoanalitičku artikulaciju. U tom je smislu sve značenje isključivo kontekstualno, odnosno sintaksa poprima značenje tek $u$ datom kontekstu. Jezik je visoko produktivna aktivnost u neprekidnom gibanju, a njegova direktna povezanost s kognitivnom razinom čini ga često neuhvatljivim: „ponekad iz njega možemo dobiti više nego što smo u njega stavili““ (Moi 2007, p. 217). Nemoguće je promatrati pojedinačne sintaktičke strukture te određivati postojanje eventualnih inherentnih kvaliteta, stoga se i Bahtin i Kristeva protive izrazima poput seksistička rečenica, muški naziv, ženska primjedba i tome slično. Prema njihovom mišljenju, svako analiziranje jezika, u smislu komunikacijskih strategija, mora pretpostavljati neesencijalistički pristup, odnosno činjenicu da pojedinci koriste isti jezik na različite načine, jednostavno iz razloga jer posjeduju i različite interese. Kristevinska semiotika jezik promatra kao neprekidan proces označivanja (procès de signifiance) te ističe njegovu heterogenu i marginalnu vrijednost. Takva je vizija nove znanosti o znakovima, semiotike, usko povezana s Kristevinom teorijom stjecanja jezika, koju je temeljito razradila u doktorskoj disertaciji La Révolution du langage poétique (Revolucija pjesničkog jezika), objavljenoj 1974. u Parizu. Oslanjajući se na modernu semiotičku znanost, Kristeva ističe nužnost proučavanja jezika kao sustava znakova, a ne simbola, stoga, preuzimajući osnovne okvire lacanovske psihoanalize, inzistira na različitoj terminologiji (Kristeva, 1974a). Lacanovo razlikovanje između imaginarnog i simboličkog, Kristeva pretvara u razlikovanje između semiotičkog i simboličkog, a međudjelovanje tih dvaju termina dovodi, prema njezinom mišljenju, do procesa označivanja. Lacanovu teoriju o stadiju zrcala Kristeva također preuzima i prepravlja, stavljajući težište na heterogene semiotičke, prededipske pulsacije, čije će cijepanje (coupure), dovesti do ulaska u simbolički poredak, odnosno do prodiranja u prostor značenja, u prostor jezika (1974a, p. 44). Umjesto edipske faze i simboličkog poretka, unutar kojih, prema Lacanu, najvažniju ulogu ima Zakon Oca (Le Nom du Père/ Le Non du Père), najvažniju ulogu u formiranju identiteta, prema mišljenju Kristeve, ima prededipska faza, odnosno semiotički poredak, gdje se kao najvažniji odnos ističe onaj majka-dijete. Prededipska faza, za razliku od one sljedeće, obiluje znakovima (sememima) ${ }^{81}$ i nije lingvistički kodificirana poput jezično dominantne edipske faze. No, inzistiranjem na važnosti odnosa majka-dijete inzistira se zapravo na važnosti svega onoga što predstavlja ono ženstveno, heterogeno i marginalno - ono suprotstavljeno zakonima jezika i zakonima monolitnog i dominantnog patrijarhalnog sustava.

\footnotetext{
${ }^{81}$ Majčine nježnosti i milovanja, njega djetetovog tijela, hranjenje i sl.
} 
Promatrajući cjelokupan Kristevin rad, kako onaj lingvistički, tako i onaj psihoanalitički, moguće je uočiti jednu jedinstvenu zajedničku poveznicu - pitanje položaja subjekta (gdje se nalazi, dakle, tko je onaj koji kazuje?). Kristeva ističe kako se pojedinac rađa u jeziku koji mu prethodi, a žena je ta koja dimenziju jezika materijalno i fizički omogućuje. U tom smislu, iako izvan Zakona jezika, predsimboličko, odnosno semiotičko starije je od samoga jezika. Ono je prvotno i iskonsko, arhaično i jezikom neizrecivo. Žena, na neki način, izgrađuje jezik simboličkog poretka, omogućuje njegovo djelovanje, no ona unutar njega ne postoji, ne pronalazi svoje mjesto. Poput kršćanske teološke dogme koja Isusovu majku izjednačava s institucijom Crkve, jer upravo je ona omogućila dolazak Boga među ljude, no ipak Marija nema svoje Evanđelje. Ona zadržava vlastitu tjelesnost u potpuno netaknutom obliku ${ }^{82}$, no njezin se glas ne čuje. Neizrecivost, nečujnost i samozatajnost čine, prema mišljenju Kristeve, nemogućim odrediti stvarnu bit i prirodu ženskog: „Stoga pod ženom razumijem ono što se ne može reprezentirati, ono što se ne izgovara, ono što ostaje izvan imenovanja i ideologija“ (1974b, p. 21). Kristeva u potpunosti sumnja u mogućnost definiranja ženskog identiteta: „Vjerovanje da ste žena gotovo je jednako apsurdno i mračnjačko kao vjerovanje da ste muškarac“ (p. 20), ističući kako je izuzetno važno odbaciti svaku teoriju ili politiku temeljenu na vjerovanju u bilo kakav apsolutni oblik identiteta jer ,što može identitet, čak i spolni identitet, značiti u novom teorijskom i znanstvenom prostoru gdje se osporava i sama predodžba identiteta?“ (1981, p. 36). Ta duboka sumnja u ispravnost definiranja ženskog, i bilo kakvog drugog, oblika identiteta Kristevu navodi i na odbacivanje ideje o specifično ženskom pisanju (l'écriture féminine) ili specifično ženskom govoru (le parler femme): „Čini se da nam ništa u prošlim ili sadašnjim ženskim publikacijama ne dopušta da potvrdimo postojanje ženskoga pisanja“ (1977a, p. 496). Kristeva ističe kako je moguće zamijetiti određena stilska i tematska obilježja koja se u tekstovima žena češće ponavljaju, međutim, nije moguće, nastavlja, sa sigurnošću reći trebaju li se ona pripisati ženstvenoj posebnosti ili utjecaju tržišta te općoj sociokulturnoj klimi““ (p. 496). Prema Kristevi, nemoguće je kvalitetno i do kraja teoretizirati pojam ženskosti ili ženstvenosti, no moguće je, tvrdi, teoretizirati pojam marginalnosti, subverzije i disidentstva ${ }^{83}$. U tom smislu, ženski se položaj može teoretizirati na isti način kao bilo koji drugi marginalan položaj u odnosu na položaj centralizirane strukture moći. Putanja marginalnosti ona je putanja kojom Kristeva povezuje

\footnotetext{
${ }^{82} \mathrm{U}$ »Djelima Apostolskim« Novoga Zavjeta opisuje se Marijino uznesenje u tjelesnom obliku.

${ }^{83}$ Kristeva, J. (1977b) »Un nouveau type d'intelectuel: le dissident« Tel Quel, 74, p. 3-8.
} 
semiotičko (prededipsko), određeno kao marginalno u odnosu na jezik, i ženstveno, određeno kao marginalno u odnosu na patrijarhat. Marginalizacija, kao oblik disidentstva, jedina je kategorija koju Kristeva povezuje uz termin ženstvenost, negirajući istovremeno bilo kakav oblik biologizma i esencijalizma. Odbacujući tako metafizičku dihotomiju između muževnog i ženstvenog, Kristeva ističe kako revolucionarni potencijal osobe nije određen njezinim biološkim spolom, kao ni tradicionalnim rodnim podjelama, već isključivo subjektnom pozicijom koju ona zauzima. 


\section{I. IV. Adriana Cavarero}

Cavarero, danas redovita profesorica područja političke filozofije na Katedri za filozofiju Sveučilišta u Veroni, uz Luisu Muraro, ključna je osnivačica filozofske feminističke skupine Diotima $^{84}$, unutar koje aktivno sudjeluje sve do devedesetih godina, kada se radi vlastitih radikalno demokratskih pozicija ipak odlučuje odvojiti ${ }^{85}$.

Tijekom studija, ali i kasnije specijalizacije, osobit interes pokazuje za antičke tekstove na izvornom jeziku, osobito one grčke, kao i za djela Hobbesa, Lockea i Hegela. Ipak, njezinu pozornost najviše privlači Platon. Njegovim je tekstovima, i cjelokupnom kritičkom bibliografijom koja ga prati, Cavarero gotovo čitavu karijeru u potpunosti posvećena.

Na njezin feministički, radikalno marksistički stav mlađih godina velik je utjecaj izvršio studentski pokret 1968. godine, ${ }^{86}$ unutar kojeg je vrlo aktivno sudjelovala i tijekom kojeg je, kako danas ističe, razvila svoja prva kritička i antiautoritarna stajališta. Sedamdesetih godina, nastavljajući svoj istraživački put usmjeren na Platonove tekstove, Cavarero dolazi u kontakt s djelima Hannah Arendt, autorice zahvaljujući kojoj je, ističe, izoštrila vještine kritičkog tumačenja književnih i filozofskih tekstova, proizvodeći u konačnici pomalo ekstremne, ali uvijek originalne političke pozicije. Veliko zanimanje pokazuje i za djela Michela Foucaulta, Jacquesa Derridaa, Waltera Benjamina te Emmanuela Levinasa, a znanje i interes u području filozofije jezika, spolnosti u jeziku, odnosno spolne razlike u jezičnom sustavu, duguje, tvrdi, prvenstveno djelima Luce Irigaray, Hélène Cixous te Judith Butler, koju danas smatra svojom glavnom sugovornicom u znanosti. ${ }^{87}$

Osnovna misao i kontekst djelovanja Adriane Cavarero mogli bi se sažeti u tri ključne točke. Prva točka sastojala bi se od tumačenja i primjene tekstova Hannah Arendt na problematiku rodnih, i drugih, odnosa u suvremenom zapadnjačkom društvu. Od tema poput

\footnotetext{
${ }^{84}$ Lik Diotime preuzet je iz Platonova Simpozija, u kojem Sokrat opisuje svećenicu iz Matineje kao svoju vrhovnu učiteljicu. Skupina je utemeljena 1983. godine u Veroni, a članice su afirmirane filozofkinje akademske zajednice, koje, krečući od temeljnih postavki Luce Irigaray o spolnoj različitosti, pokušavaju rehabilitirati žensku i ženstvenu prisutnost u filozofskoj znanosti.

${ }^{85}$ O čemu više govori u knjizi Democrazia Sorgiva (Cavarero, A. (2019) Democrazia Sorgiva. Note al pensiero politico di Hannah Arendt. Milano: Raffaello Cortina).

${ }^{86} \mathrm{U}$ Italiji poznat kao muovimento dei sessanttottini.

${ }^{87} \mathrm{Za}$ talijanski je prijevod Butlerine knjige Bodies That Matter. On the Discursive Limits of Sex. Cavarero napisala predgovor (Butler, J. (1996) Corpi che contano. I limiti discorsivi del sesso. Milano: Feltrinelli).
} 
rađanja i majčinstva, pa sve do alternativnih i pomalo radikalnih interpretacija jezičnih i kulturnih simbola. Druga točka, ona u kojoj se filozofija i lingvistika neprestance prepliću, bila bi istraživanja vezana uz teoriju spolne različitosti i spolnih razlika unutar jezičnog prostora. I treća točka, ona koja ujedno objedinjuje prethodne dvije, jest Cavarerin pokušaj da usamljenom i apstraktnom filozofskom subjektu suprotstavi konkretan i tjelesan subjekt, subjekt označen vlastitim ljudskim urođenim potrebama za odnosima s drugim bićima.

Cavarero je u velikoj mjeri pridonijela razumijevanju i razvoju teorije spolne različitosti i seksualnosti u jeziku, s osobitim naglaskom na specifičan književni i filozofski jezični registar. U svim svojim teorijskim razmatranjima, prati onaj umjeren visokointelektualan $i$ sofisticiran francuski feminizam koji, za razliku od onog anglosaksonskog, ne razdvaja žensko i muško od ženstvenog i muževnog, ${ }^{88}$ već usvaja termin différance kojim, kao i njezine francuske kolegice, označava nedjeljivost biološko-morfološkog obilježja od simboličkog poretka koji subjekt zauzima.

Znanstveni radovi koji bilježe najveći uspjeh Cavarero piše i objavljuje između godine 1987. te 1997., a njezino prvo istraživanje seksualnih razlika u jeziku, Per una teoria della differenza sessuale ${ }^{89}$ (Za jednu teoriju spolne različitosti) iz 1987., ujedno je i najpoznatije. U njemu autorica podrobno analizira glavne uzroke i posljedice razlika u jeziku između dvaju spolova, a osnovno je težište cjelokupne analize prebačeno na problematiku rodnoga jezika (il linguaggio di genere), odnosno na istraživanja različitosti u smislu društva i društvenih uloga, ne spolnih i tjelesnih kategorija.

Cavarerin se rad tako u velikoj mjeri podudara s knjigom Patrizije Violi, L'infinito singolare. Considerazioni sulle differenze sessuali nel linguaggio (Beskonačna jednina. Razmatranja o spolnim različitostima u jeziku), objavljenom tek godinu prije Cavarerinog rada, u kojoj Violi također analizira koncept 'različitosti u jeziku' iz feminističke, odnosno rodne perspektive.

Naglašavanje rodne, a ne spolne, različitosti, u jezičnim analizama obiju autorica od izuzetne je važnosti. Naime, spolna različitost simbolički se očituje unutar jezika prvenstveno putem rodnih kategorija. U tom smislu, rod nije isključivo gramatička kategorija koja

\footnotetext{
${ }^{88}$ Razdvajajući biološko određenje (spol) od kulturnog obilježja (rod).

${ }^{89}$ AA.VV. (1987) »Il pensiero della differenza sessuale« u: Diotima. Milano: La Tartaruga, pp. 52-55; 78.
} 
usklađuje onu spolnu, već, na neki način, predstavlja samostalnu semantičku kategoriju koja emanira određeni simbolizam vezan uz tijelo. Prema Violi (1986, p. 41), a i prema Cavarero (1987, p. 78), rod unutar jezičnog jest simbolizacija spolne različitosti, no sam jezik predodređuje strukturu budućih spolnih uloga, koje, ulazeći u ritam svakodnevne komunikacije, ostvaruju naknadnu jezičnu reprodukciju i smisao. ${ }^{90}$

Obje se autorice, krečući od binarne analize, pa sve do one dekonstrukcijske, u velikoj mjeri bave analizom muškog i ženskog, odnosno muževnog i ženstvenog, odnosa. Prema Violi, muškost i ženskost, kao i muževno i ženstveno, iako bi po svemu sudeći, trebali posjedovati jednak status, jednaka prava, ipak ih ne posjeduju. Naime, Violi ističe kako je ,derivacijska veza“991 ono što spaja, ujedno i razdvaja, muško od ženskog. Žensko i ženstveno derivacije su muškog i muževnog, a vlastiti smisao ostvaruju tek kao „negacija“ na ono prvotno i izvorno (1986, p. 11).

Razmatrajući koncept 'različitosti', Cavarero ide korak dalje, te ističe kako žena ne posjeduje vlastiti jezik, već posuđuje jezik onog drugog. Ona se tako ne osjeća, i ne može osjećati, osviještenom i sigurnom da vlastitim riječima prikaže svijet, pa ponekad jednostavno „govori tišinom“92 (Cavarero, p. 53). Materinji jezik ${ }^{93}$, općeprihvaćena i uvriježena definicija prvog usvojenog jezika, prema mišljenju Cavarero, uopće ne postoji: „Taj jezik ne postoji, jer jezik žene, prije svega, ne postoji“ (p. 52). Jezik koji prihvaćamo i usvajamo kao prvi, za žene je, na neki način, strani jezik usvojen prijevodnim putem. ${ }^{94}$ Lacanovska psihoanaliza, na koju se Cavarero očito naslanja, edipsku krizu predstavlja kao trenutak u kojem se stječu jezik i nesvjesno, trenutak ,izlaska iz prededipskog područja imaginarnog te ulazak u simbolički prostor jezičnih zakona“" (Homer 2005, p. 25). Ulazak u simbolički poredak znači prihvaćanje zakona Oca, odnosno znaka Falusa i njegove označiteljske uloge. Kako je u zapadnom društvu Otac nositelj primarnog zakona, ${ }^{95}$ onaj koji otvara vrata simboličkog svijeta jezika i

\footnotetext{
90 „Mi smo ti govoreni u jeziku, ne oni koji taj jezik govore“ (Lepschy 1989, p. 61).

${ }^{91}$ Aludirajući na Knjigu Postanka iz Petoknjižja Staroga zavjeta, trenutak u kojem se opisuje nastanak prve žene izvlačenjem muškarčeva rebra, na ženu kao „muškarčev neesencijalni dodatak“ (Beauvoir 2016, p. 165).

${ }^{92}$ Ovim se aspektom jezika ponajviše bavio francuski feminizam koji razlike u jeziku traži upravo u tišini: $u$ interpunkciji, u razmaku, u ritmu i tonu, u praznom prostoru između redaka, u ekstratekstualnom.

${ }^{93}$ U ovom slučaju Cavarero koristi termin majčinski (lingua madre).

${ }^{94} \mathrm{~S}$ naglaskom na činjenicu da izvornik zapravo i ne postoji.

${ }^{95}$ Misli se prvenstveno na zabranu incesta.
} 
kulture, omogućujući konstituiranje subjekta te uspostavu spolne razlike i identifikacije, kao i rađanje nesvjesnog prostora, Cavarero je u pravu kada tvrdi da institucija materinjeg, odnosno majčinskog, jezika u naravi ne postoji. U tom jezičnom raskoraku, u prijevodnom međuprostoru, otvaraju se, tvrdi Cavarero, tišine koje govore, jer „u tišini nijem je zvuk, ne riječ“ (Cavarero 1987, p. 53). Iz tog razloga, ističe autorica, žene najčešće pribjegavaju poeziji, romanu i autobiografiji. Ti im oblici omogućuju da prazne prostore nadopune vlastitim jezikom, da se ne osjećaju kao da ,jesu jezik“, već kao da „posjeduju jezik“(p. 55), jasno aludirajući na lacanovski koncept „bivanja Falusom“ koji označava ženski položaj užitka (jouissance) izvan i onkraj jezika, te koji izmiče integraciji i označavanju simboličkog poretka, ${ }^{96} \mathrm{u}$ odnosu na koncept ,posjedovanja Falusa“, dakle posjedovanja zakona i jezika, koji, u tom smislu, jedini označava mogućnost uspostave subjekta i tvorbu identiteta.

Prema mišljenju Adriane Cavarero, jezik književnosti jezik je tolerancije i uvažavanja, jezik koji poznaje i priznaje razlike. Za razliku od jezika filozofije koji je tradicionalno monistički i patrijarhalno usvojen. Baveći se prije svega političkom filozofijom, Cavarero razmatra utjecaj kapitalnih djela antičke filozofije na razvoj modernog društva. U Nonostante Platone (Usprkos Platonu, 1990a), prebirući po Platonovim i Homerovim djelima, autorica izdvaja nekoliko ženskih likova (Penelopu, Demetru i Diotimu), te njihove priče umata u novo ruho, ne bi li dokazala svevremenu snagu ovih kultnih figura Antike te činjenicu da je mitološki svijet matrijarhata gotovo nasilno ugušen pretežito mizoginim interpretacijama velike većine antičkih tekstova. Prema Cavarero, zapadnoeuropska kulturna tradicija naslijeđe je simboličkog, nasilno uvedenog, patrijarhalnog kodeksa, utjelovljenog u nekoliko ključnih muških reprezentacija, među kojima se ponajviše ističu Edip, Odisej, Polifem, Faust, Don Giovanni, Cirano te Werther. Kroz vrijeme ti su likovi bivali sve snažniji. U trenutku prelaska iz antičkog svijeta mythosa u moderan svijet logosa, odnosno iz romantičarske vizije svijeta u sferu realizma, potonji su likovi, prema mišljenju autorice, ostvarili golem i nerealan profit, ostavljajući na marginama žensko i ženstveno. Naime, grčki je svijet mythosa, oblikovan po načelu mjesta, vremena i radnje, s vremenom snažno odijelio svijet glavnih likova u odnosu na njihov spol. Oni su ratnici, moreplovci, osvajači, veliki ljubavnici, uspješni pjesnici, utjecajni filozofi i političari. One su ljupke i krotke robinjice, poslušne i kući privržene domaćice, demoni ili svećenice, čije misli, kao u slučaju Diotime ${ }^{97}$, prenosi netko od

\footnotetext{
${ }^{96}$ Žena obilježena kao prostor seksualnog prodora.

${ }^{97}$ U Platonovu Simpoziju (201 d) filozofsku misao poznate svećenice Diotime iz Matineje prenosi Sokrat.
} 
poznatijih muških autora. Oni koračaju planinama, plove oceanima, love po šumama, one strpljivo kroje u osamljenom kutku vlastitog doma, čekajući onog stranca kojem više lik ne prepoznaju, onog koji je osjećaj doma odavno izgubio. U raspravi o Platonovu Fedonu ${ }^{98}$ Cavarero nudi posve drugačiju interpretaciju Homerove Penelope, čije se naoko uzaludno čekanje pretvara u simboličko ujedinjenje svega onoga što je filozofija, kao prvenstveno muška disciplina, sjedinila i udaljila. Platonov nas Fedon uvodi u zatvor gdje Sokrat provodi svoje posljednje trenutke na životu, razmišljajući o smislu konačne smrti, o njezinom uzvišenom poslanju na ovome svijetu. Za Sokrata je smrt konačna nagrada u životu jednog filozofa, ona će u potpunosti razjediniti duh i tijelo, te na taj način osloboditi um od okova materijalnog i tjelesnog, od svega onoga što sputava i otežava put k mentalnom uzvišenju, $\mathrm{k}$ uzvišenim idejama, k onim stvarima „koje uvijek jesu“. 99 To življenje radi smrti, smatra Arendt, ${ }^{100} \mathrm{u}$ temeljima je zapadnjačke filozofske tradicije: „duž cijele povijesti zapadnjačke filozofije prisutna je jedinstvena ideja o svojevrsnom afinitetu između smrti i same filozofije“ (1987, p. 162), dok je Platon, smatra Cavarero, prvi među jednakima čiji se životni put običnim smrtnicima čini kao neprestana težnja k smrti (1990a, p. 33). Na početku Fedona Platon objašnjava glavno poslanje filozofije kao najuzvišenije umne discipline koja pripada muškarcima. Ona je jedina znanost koja u potpunosti oslobađa, ona jedina ima sposobnost imitirati smrt, odvojiti dušu od tijela i tako udaljiti čovjeka od prizemnih ovozemaljskih strasti, od boli i užitaka koje čovjeka čine životinjom, jer svaka težnja za ujedinjenjem duha i tijela dovodi, smatra Platon, u propast. U pakleni perpetuum mobile koji metaforički prikazuje upravo kroz lik žene, Penelope, koja danju sastavlja (kroji), da bi noću rastavljala, pokušavajući ujediniti ono što su patrijarhat i filozofija, kao prvenstveno patrijarhalna znanost, rastavile. Penelopa svijet nanovo sastavlja, lobira za život, ne smrt, i ne teži onozemaljskim idejama, već ovozemaljskim iskustvima. Njezin jezik nije jezik filozofskih bogova, već jezik stvarnosti i osjećaja. Njezin jezik stapa dušu i tijelo progovarajući u jednom jedinstvenom tonu koji prati ritam psyhe, ali i some. Kao žena prisutna je ovdje, u ovome trenutku, na ovome mjestu s kojeg progovara. Ona nije poput Talesa čiji je pogled vječno

\footnotetext{
${ }^{98}$ Fedon (84 a-b).

${ }^{99}$ Ta onta.

${ }^{100}$ Arendt, H. (1987) La vita della mente. Bologna: Il Mulino, p. 162.
} 
usmjeren u nebeska tijela, tako da i ne opaža obližnji bunar. ${ }^{101}$ Ona je karnalna predodžba ovozemaljskog, ljupka i krotka robinjica iz Trakije koja Talesu pruža pomoć, dražesno se osmjehujući i na taj način ironično dovodeći u pitanje primat filozofske misli i svih onih tekovina koje ona u zapadnjačkoj kulturi i jeziku ostavlja. Podsmjehuje se ona, dražesna i privlačna robinjica, piše Cavarero (p. 58), ona koja nije ni boginja, ni kći sunca, ni svećenica, ona koja pripada svijetu kuće i ognjišta, ona koja odlazi po vodu da bi očistila i skuhala, ona koja je od samih početaka označena stigmom drugosti, ona nepredočena u ontološkoj sferi poimanja bitka, ona koju se ne vidi kada se u ogledalu upiše riječ čovjek.

Zaokupljena pronalaskom glavnoga krivca za lošu sudbinu zapadnjačke filozofije, Cavarero raspravu o mizoginim interpretacijama grčke mitologije nastavlja otvaranjem mita o božici Demetri. Naime, kako Tilde Giana Gallino u Velikim Majkama ${ }^{102}$ objašnjava, Demetra je univerzalni simbol Velike Majke: ,apsolutnog božanstva, koje, jasno posjedujući tajne života i plodnosti, jedina ima moć da ih prenosi i umnožava“ (p. 8). Kod Platona su, međutim, kako tvrdi Cavarero, prirodna sila i snaga, koje izviru iz Demetre, znakovito poremećene, a Kratil, djelo u kojem Platon posvećuje kutak mitu o božici plodnosti, zasigurno je početak kulturnog prelaska matrijarhata u patrijarhat. Mit o Demetri i Hadu opisuje božicu plodnosti kao vječnu toplinu i energiju koja stvara, kao onu koja odlučuje o životu. Ona je nježna majka prelijepe božice Kore u koju se zaljubljuje bog podzemlja Had - bog vjećnog mraka i hladnoće, vladar pustoši i samoće ${ }^{103}$. Had otima Koru iz majčinih ruku i odvlači je u podzemlje. Majka zbog toga tuguje i gubi svoju stvaralačku energiju te zemlja polako odumire. Nakon izvjesnog vremena, Had ipak pristaje na kompromis te periodično (u ljeto i proljeće) Koru prati da posjeti majku, jer kako Cavarero ističe: „Demetra se ne zadovoljava činjenicom da je kći zbrinuta, ona je želi vidjeti, želi u njoj uživati“ (Cavarero 1990a, p. 152). Prema mišljenju Luce Irigaray, ${ }^{104}$ mit o božici Demetri predstavlja ključan trenutak u razvoju antičke

\footnotetext{
${ }^{101}$ U Platonovu Teetu (174a) opisan je Talesov pad u bunar dok je koračao gledajući u zvijezde. U pomoć mu je pristigla robinja iz Trakije čiji je osmijeh postao centar ove anegdote i metafora za nužnost razumijevanja ovozemaljskih iskustava i pojava (Blumenberg, H. 1988, Il riso della donna di Traccia. Il Mulino: Bologna).

${ }^{102}$ Gallino, T. G. (1989) »Le Grandi Madri: un'introduzione al mito e all'archetipo« u: Le Grandi Madri. Milano: Feltrinelli, p. 8.

${ }^{103}$ Znakovito je kako je već Aristotel u potpunosti zaokrenuo ovu genealošku paradigmu antičke Grčke te često isticao žensku reproduktivnu funkciju kao pasivnu i hladnu, dok je onu mušku uzdizao tvrdeći kako je ona ta koja svojom pokretljivošću i snagom daruje život (Sissa, G. »Il corpo della donna. Lineamenti di una ginecologia filosofica« u: Campese, S.; Manuli, P.; Sissa, G. 1983, Madre Materia. Torino: Boringhieri, p. 81-145.)

${ }^{104}$ Irigaray, L. (1989) Sessi e genealogie. (prev. na tal. Muraro, L.) Milano: La Tartaruga, p. 151.
} 
filozofske misli. On je prvi otvoreni šav prekinutih veza ženske genealogije, koji je u potpunosti odijelio žensko od nadolazećeg patrijarhalnog poretka te na taj način potpisao sudbinu zapadne kulture. ${ }^{105}$ No, ako ovdje izuzmemo činjenicu da mit o božici Demetri govori, među ostalim, i o sposobnosti, odnosno mogućnosti ženskog spola da donosi odluku o stvaranju ili o uništenju, da donosi na ovaj svijet sudbine u obliku obaju spolova, ${ }^{106}$ muškog i ženskog, možda se ipak ključnim elementom ove priče čini trenutak majčinog pogleda. Cavarero, naime, ističe važnost metaforičkog ključa koji otvara samu bit mita - ženama su prijeko potrebni uzajamni pogledi, uzajamna bliskost i prisutnost vlastitog spola (1990a, p. 68-71). Ne videći jedna drugu, žene ne vide jasno sebe. Pogled majke u kćeri pogled je žene u ženi. Vlastiti je spol za svaku ženu horizont njezinog prepoznavanja, a vizualna komunikacija ženskome spolu omogućava da povrati one odlomljene krhotine, fragmente, ženskog identiteta koje je patrijarhalno društvo rasulo, jer kako i Françoise Collin u Misliti/Pripovijedati ${ }^{107}$ ističe: ,komunikacija među ženama prehranjuje se prvenstveno sučeljavanjem životnih priča, a ne konfliktom velikih ideja“ (p. 37). U knjizi Auto/biografsko Ja: Teorija i praksa feminističke auto/biografije (The Auto/biographical I: The Theory and Practice of Feminist Auto/biography) ${ }^{108}$ Liz Stanley sociološkim postmodernim i poststrukturalističkim feminističkim pristupom razmatra ženske i ženstvene narativne sposobnosti i metode, ističući uvijek prisutan ženski interes da se priče drugih žena, dakle vlastitog spola, pročitaju i poslušaju. U pozadini svega toga, tvrdi Stanley, nalazi se želja za isticanjem vlastitih životnih iskustava kao onima vrijednih spomena ili kako ih autorica naziva „lives-with-meaning“ (p. 20). Američka i francuska, obje vrlo utjecajne, postmodernistička kulturna scena, donose novitete na polju autobiografije, osobito one ženske, i to kako na polju naracije te same tehnike pisanja, tako i na polju interpretacije. Naime, ono što se u znanosti o književnosti prepoznaje kao klasična autobiografija $a^{109}$ podrazumijeva prisutnost jednog jedinstvenog, stabilnog, snažnog i nepokolebljivog subjekta,

\footnotetext{
105 Kora, naime, prelazeći u muški poredak, u svijet kojim vlada znak Falusa, Lacanovim rječnikom iz prostora Imaginarnog u prostor Simboličkog, nije više Demetrina kći, već Hadova supruga, a njezina su djeca njegova djeca, noseći njegovo prezime.

${ }^{106}$ Cavarero, A. (1990) »Dire la nascita $«$ u: AA.VV. Diotima. Mettere al mondo il mondo. Milano: La Tartaruga, p. 93-121.

${ }^{107}$ Collin, F. (1986) Pensare/Raccontare. Hannah Arendt. DWF 3, p. 37.

${ }^{108}$ Stanley, L. (1992) The Autobiographical I: The Theory and Practice of Feminist Auto/biography. Manchester and New York: Manchester University Press.

${ }^{109}$ Poput Rousseaueovih i Goetheovih djela.
} 
kompaktnog i ujedinjenog sebstva, koji se u toj vrsti autonaracije, na neki način, samopotvrđuje (Cavarero 1997, p. 91). U tom smislu, njegova je autobiografija svojevrsno ogledalo već izgrađenog i nadasve postojanog identiteta. Takav teorem klasične autobiografije, ističe Cavarero, govori o prisutnosti jednog sveznajućeg subjekta koji, pripovijedajući vlastiti život, preuzima ulogu prevoditelja, prenoseći vlastita iskustva iz svijeta realnog u pisani medij svijeta fikcije, držeći pritom znatan odmak svoje ,psihološke esencije“, svoga vlastitog $J a$, u odnosu na tekst koji mu služi (p. 91-101). S druge strane, razdoblje postmodernizma i poststrukturalističke teorije $u$ potpunosti je izmijenilo koncept autobiografskog. Janet Varner Gunn ${ }^{110}$ ističe kako se $\mathrm{u}$ antimetafizičkom horizontu poststrukturalističke teorije ne nazire postojanje univerzalnog i jedinstvenog $J a$ izvan jezičnih granica teksta (p. 30), odnosno sam je tekst stvoritelj onog koji progovara, autora ili pripovjedača. Tekst je taj koji donosi kontinuitet, stabilnost i jedinstvenost vlastitom $J a$, koje sada njemu služi. Ja je tako produkt teksta, rezultat performativne moći retoričkih tekstualnih strategija, a autorovo/pripovjedačevo sebstvo čisti je efekt moći jezika. ${ }^{111} \mathrm{U}$ tom smislu, postmodernisti i postmodernistička feministička kritika u sintagmi autobiografsko kao ključan element ističu upravo graphein, ne auto i bio. U poglavlju knjige Tu che mi guardi, tu che mi racconti $^{112}$ (Ti koja me gledaš, ti koja mi pripovijedaš) naslovljenom „In una libreria di New York“113 („U jednoj njujorškoj knjižari“), Cavarero analizira potonje dvije vrste autobiografskog izričaja, te dolazi do zaključka kako su one uvelike određene spolnim razlikama. Naime, ženstven pristup autobiografskom sastoji se upravo od negiranja jedinstvenosti i nadmoći autorovog $J a$ nad vlastitim tekstom, negirajući istodobno čitavu falogocentričnu zapadnjačku tradiciju koja sposobnost sinteze i unifikacije prepisuje Njemu, dok istodobno „fragmentiranost, nedosljednost i rezistentnost na svaku moguću sintezu prepisuje Njoj“ (Battersby 1989, p. 151). ${ }^{114}$ Ženske su biografije i autobiografije, prema mišljenju Adriane Cavarero, multifragmentiran slijed životnih segmenata, koji vlastito mjesto i značaj traže upravo u jeziku, u tekstu. Taj život, koji čeka u redu da bude ispričan, svoj oblik i značaj ostvaruje tek unutar teksta koji ga kroji, odnosno u beskonačnim hermeneutičkim

\footnotetext{
${ }^{110}$ Gunn, J. V. (1982) Autobiography. Toward a Poetics of Experience. Philadelphia: University of Pennsylvania Press, p. 30.

${ }^{111}$ Ovim se tezama vraćamo na Barthesovu izjavu o smrti autora te ideji o nadmoći jezika.

${ }^{112}$ Cavarero, A. (1997) Tu che mi guardi, tu che mi racconti. Milano: Feltrinelli.

${ }^{113}$ New York ovdje nije slučajno odabran grad. On je simbol velikog postmodernističkog zaokreta.

${ }^{114}$ Battersby, Ch. (1989) Gender and Genius. London: The Women's Press.
} 
mogućnostima kojima raspolaže čitatelj/-ica. Kako bi što slikovitije prikazala ovu izuzetno važnu distinkciju između muške i ženske autobiografije, muževnog i ženstvenog autorstva, Cavarero ženski stvaralački proces uspoređuje s pričom o liku rode u blatu Karen Blixen. U romanu, naime, jedan od likova, čuvši neobične zvukove, u gluho doba noći diže se iz toplog kreveta, no zapinje i pada u blato. Vraćajući se u kuću, nakon što je popravio rupu koja je proizvodila buku, vlastitim cipelama ostavlja tragove u obliku rode. Probudivši se sutradan, ostaje šokiran onime što vidi: „Kako li sam samo to uspio napraviti?““ (p. 200). ${ }^{115}$ Cavarero tumači kako je upravo ovom anegdotom Karen Blixen metaforički zapečatila ključ ženskog teksta - činjenicu da se njegov smisao krije upravo u jednom jednostavnom i nadasve spontanom slijedu okolnosti, u potpuno slobodnim i neovisnim narativnim sekvencama, bez ikakvih velikih projekata koji im prethode. Ukratko, zaključuje Cavarero, životne priče i puteve ne određuje konačni crtež, već životni putevi ostavljaju tragove koji možda mogu postati upravo taj crtež. To je oznaka retorike apsolutne slobode, lišene svih predrasuda i okova postojećih kanona.

Neka ključna razmatranja i stanovišta, u pogledu uporabe jezika u odnosu na spol, Cavarero je još jednom sažela u zbirci teorijskih tekstova pod nazivom Il pensiero femminista. Un approccio teorico ${ }^{116}$ (2009) u kojoj nanovo optužuje zapadnjačku kulturnu tradiciju jer je pojmom različitost, u spolnom i jezičnom smislu, označila ne dvije jednako vrijedne i na istoj razini suprotstavljene ontološke biti, već dva u potpunosti udaljena hijerarhijski strukturirana termina, od kojih je jedan nadređen i uključiv, dok je drugi podređen i isključiv (p. 81). Taj etablirani sustav znakova, ističe Cavarero, služi se terminom različitost kako bi isključivo ojačao i potvrdio univerzalni koncept čovjeka kao prvenstveno modela muškog roda, rođenog i razvijenog unutar bipolarne logike simboličkog poretka kojim isti vlada. Taj patrijarhalan sustav postavlja muškarca kao subjekta s oznakom cjelovitog sebstva, a njemu suprotstavlja ženu kao objekt s oznakom njegovog drugog, kao onog koji vlastitu poziciju traži i ostvaruje u odnosu na falusni centar: „Ta druga, ne drugačija, već upravo druga jer nastaje nakon njega, prvog, nastaje za njega. Ta druga bez vlastite riječi, bez vlastitih znakova, koja zauzima mjesto u imaginariju koji joj ne pripadaju“ (p. 84). Upravo iz tog razloga, Cavarero patrijarhalnu zapadnjačku tradiciju smatra doslovce homoseksualnom, jer je glavni i jedini akter simboličkog poretka isključivo muškarac, a jezik koji tu istu tradiciju strukturira i

\footnotetext{
${ }^{115}$ Blixen, K. (1959) La mia Africa. Milano: Feltrinelli.

${ }^{116}$ Cavarero, A.; Restaino, F. (2009) Le filosofie femministe. Milano: Bruno Mondadori.
} 
oblikuje smatra taocem androcentričnih mizoginih pretpostavki. Tu je osnovnu tezu o zapadnjačkim kulturnim simbolima i jeziku koji gradi falogokratičan sustav razmišljanja, Cavarero ilustrativno prikazala i u poglavlju o Adamu i Evi svoje knjige Inclinazioni $(\text { Naginjanja })^{117} \mathrm{u}$ kojem analizira dva poznata ulja na platnu američkoga konceptualnog umjetnika Barnetta Newmana izložena u muzeju moderne umjetnosti u Londonu pod nazivom „Adam i Eva“ iz 1951., odnosno 1950. godine. Cavarero skreće pozornost na široku centralnu vertikalnu os duž tamno označene pozadine (Adam) u odnosu na tanku marginalnu liniju koja kao da ne uspijeva zadržati i umiriti taj kaotičan i nemiran bezdan, tu prazninu koju je gotovo nemoguće omeđiti i oblikovati (Eva). Cavarero smatra kako je upravo Newman, ovim apstraktnim prikazima, iznjedrio esencijalnu paradigmu zapadnjačke kulturne tradicije - Ona (Eva) u ontološkoj sferi poimanja bitka označena je kao praznina, upravo poput ovog ulja na platnu koje kao da čeka da se u njega nešto upiše, da se doda, jer žena još nije zadobila vlastiti oblik, vlastito mjesto, vlastitu ulogu u svijetu. Ona je i dalje ovdje, čeka da je se pronađe.

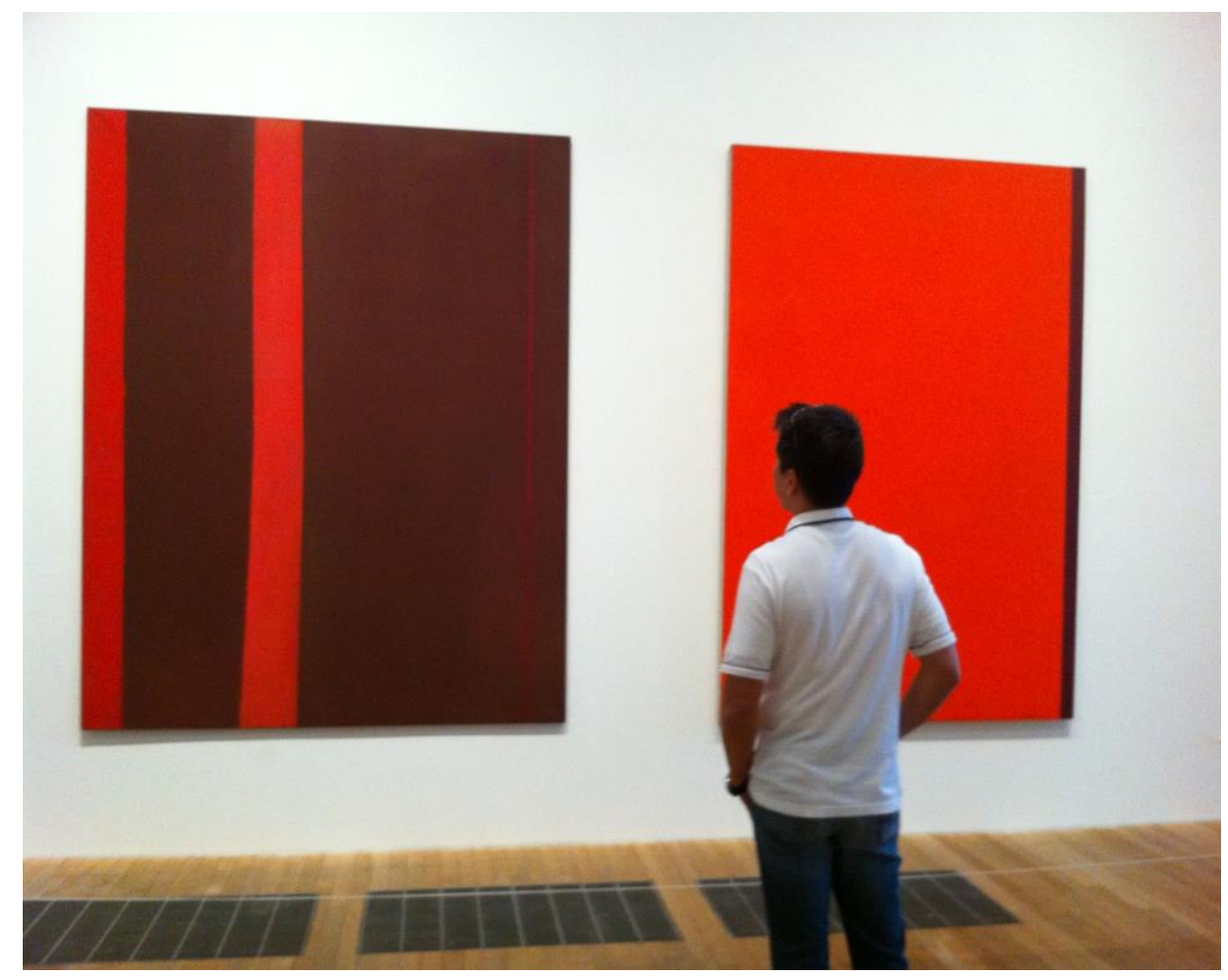

Slika 1. Barnett Newman, Adam (ulje na platnu) 1951., Eve (ulje na platnu) 1950., Tate Modern, London.

${ }^{117}$ Cavarero, A. (2014) Inclinazioni. Critica della retitudine. Milano: Raffaello Cortina. 
Pomoću jezika gradimo kontakt s vanjskom zbiljom. Jezična nas pravila uvode u temeljna pitanja identiteta. ${ }^{118}$ Jezikom i komunikacijom ukazujemo na stanje u društvu, na društvene odnose, na odnose pojedinaca i kategorija. I ne samo to. Jezikom, iz dana u dan, to isto društvo izgrađujemo. No, jezik jest, iznad svega, semiološki fenomen (Saussure 2003, p. 9596). Stoga, kao takav, izvan granica društvene stvarnosti, društvenih kategorija i uloga, ne postoji. Da bi jezik postojao, potreban je „onaj netko“ tko se njime, na ovaj ili onaj način, služi.

Upirući prstom u filozofiju i lingvistiku, koje su, po njezinu mišljenju, u velikoj mjeri pridonijele marginalizaciji ženskog i ženstvenog, Cavarero nastoji ukazati na nužan odmak od prikrivenih androcentričnih teorija i zaključaka, kako bi se stvorili preduvjeti za oformljavanje novog, jedinstvenog i različitog ženskog jezika. Iz pozicije političke filozofije, razmatrajući utjecaj jezika filozofije na razvoj zapadnjačkog falogokratičnog sustava razmišljanja, autorica lobira za temeljite i korijenite lingvističke, znakovne, promjene. Na taj način, direktnim utjecajem na razvoj i stabilnost kulturnih simbola, poništile bi se tekovine zapadnjačkoga filozofskog diskursa koje ženu predstavljaju kao zrcalni odraz, odnosno kao „,negativ muževne refleksije“ (Irigaray 1974, p. 20).

Cavarerina teorija različitosti nadilazi onu biološko-morfološku, ali i bilo koju drugu koja podrazumijeva bipolarne aspekte promatranja, kao i hijerarhijski strukturirane sustave. Spolno i rodno jesu oznake nejednakosti, dakle različitosti. No, ta različitost ne razdvaja biologiju od kulture, morfologiju i fiziologiju od jezika i govora.

\footnotetext{
118 „Jezik je organ koji oformljuje misli“ (Humboldt, prema Steiner 1994, p. 113).
} 


\section{II. (NADO)GRADNJA IDENTITETA}

\section{II. I. Identitet kao metafizički konstrukt}

Posljednja, suvremena, faza feminističkih istraživanja počinje sredinom osamdesetih godina i traje sve do početka novog stoljeća. U toj fazi dolazi do konkretne akademizacije feminističke teorije. Dok je većina prethodnih feminističkih pokreta bila koncentrirana na političke ciljeve, ovaj novi feminizam djeluje „ispod površine“. Rafiniranim teorijskim instrumentima njegove začetnice, sveučilišne profesorice u području humanističkih znanosti, nastoje dekonstruirati i dovesti u pitanje pojmove poput identiteta, subjekta, spola, tjelesnog. Njihova se istraživanja temelje uglavnom na radovima francuskih autorica, Irigaray, Cixous i Kristeve, zaokupljenih pitanjima ženskog pisanja, autorima nove poststrukturalističke teorije poput Derridaa i Foucaulta te postmodernističkim prvacima Deleuzeom i Lyotardom.

Tekst koji najuvjerljivije svjedoči o ovoj promjeni paradigme sredinom osamdesetih godina jest Manifest za kiborga iz 1985. godine Donne Haraway, znanstvenice Odsjeka za biotehnologiju Sveučilišta Silicon Valley u Kaliforniji. Manifest je objavljen u znanstvenom časopisu Socialist Review, a temelji se na činjenici da je informatika potpuno izmijenila vrijednosne sustave i tako dovela u pitanje pojmove poput materije, tijela, identiteta, realnog. Haraway, živeći tada u informatički najevoluiranijem dijelu svijeta, primjećuje kako se ljudi polako pretvaraju u, kako ih ona naziva, kiborge (cyborg). Radi se o bićima koja su napola strojevi (cyb označava kibernetiku), a napola živa bića (org označava živući organizam): „Cyborg je kibernetsko biće, hibrid stroja i živućeg organizma, biće koje pripada društvenoj stvarnosti u onoj mjeri u kojoj pripada fikciji“ (p. 40). U svijetu u kojem borave kiborgi gube se distinkcije između ljudi i životinja, strojeva i živih bića, tijela i uma, spola i društvenih uloga. U svijetu u kojem je teško odrediti što je doista stvarnost, je li to ono materijalno golim okom vidljivo ili je to neka metafizička razina svijesti, dolazi u pitanje identitet. Umjesto riječi identitet, Haraway predlaže riječ afinitet, navodeći kako je klasično shvaćanje pojma identitet u prošlosti bilo usko povezano s maskulinističkom, androcentričnom vizijom svijeta. Prateći misao Julie Kristeve i Michela Foucaulta, Haraway odbija definirati žensko odnosno muško, te prihvaća tezu o identitetu kao sociokulturnom konstruktu, a ne kao biološki datom pojmu. 
I za britansku teoretičarku Christine Battersby, sa Sveučilišta Warwick, identitet postaje metafizički element u neprekidnoj fazi nadogradnje/rekonstrukcije. U knjizi The Phenomenal Woman (1998, pp.1-4; 7) Battersby pokušava zaokrenuti cijelu zapadnjačku koncepciju metafizike, nudeći alternativno objašnjenje pitanjima identiteta, spola i osobnosti pojedinca. U knjizi navodi kako u svemu postaje ključan sam čin rađanja - žena je subjekt koji se, na neki način, duplicira u dvojac majka-dijete. Dijete nakon poroda postaje ovisno o majci, a formiranje prvih obrisa identiteta i osobnosti ovise upravo o toj vezi s majkom. Dijete, dakle, nije kako tvrde Heidegger i Sartre „pojedinac bačen u svijet“, već se ono razvija i raste u odnosu s drugim bliskim živim bićima. Nakon majke to su kasnije druge bliske osobe i iskustva. U tom smislu, čovjekov identitet u neprekidnoj je fazi evolucije, a svaka od naših karakternih uloga nije nikad trajna i konačna. 


\title{
II. II. II. Nomadski subjekt
}

Talijanska znanstvenica sa Sveučilišta u Utrechtu, Rosi Braidotti, nastavlja graditi most između novog feminizma, poststrukturalizma (Foucault) te postmodernog (Deleuze) objavom radova Patterns of Disonance (1991) te Nomadic Subject (1994), karakterizirajući feminizam do osamdesetih kao nepoželjnu društvenu pojavu jer je nasilno unio pojam tjelesnog i seksualnog unutar filozofskog diskurza. Po uzoru na Derridaa, Braidotti potpuno ignorira ono tjelesno i materijalno u vezi sa spolom i identitetom. Za nju je tjelesnost na svakojake načine sputana i uvjetovana društvenim normama i očekivanjima. Ona je kulturna nadogradnja, lingvistički i sociološki konstrukt.

Teorija Rosi Braidotti o identitetu kao o putujućem i fluktuirajućem pojmu kreće od filozofskih postavki Gillesa Deleuzea o nomadizmu. ${ }^{119}$ Braidotti, naime, tvrdi kako spolna različitost nije nikad konačna i monolitna, naprotiv, ona se protivi bilo kakvoj političkoj definiciji i nestalnog je oblika:

\begin{abstract}
Unutar područja feminističke teorije govori se o ženi, iako taj subjekt zapravo nije konačan monolitan oblik, već mjesto unutar kojeg se prepliću višestruka iskustva, slojevita i potencijalno kontradiktorna, prostor koji definiraju društvena klasa, rasa, dob, stil života, seksualna orijentacija itd. (Braidotti 2002, p. 13)
\end{abstract}

Pojam nomadskog subjekta, objašnjava Braidotti, svakako proizlazi iz antropoloških iskustava. Nomadski su narodi i kulture stoljećima predstavljali one bez domovine, bez prava i glasa, bez konkretnog identiteta. Naravno, ovdje se ne radi o takvoj vrsti nomadizma, već o drugačijoj razini svijesti, o želji da se promijene i preokrenu ustaljene dogme, politička uvjerenja i stavovi. U tom smislu, Braidotti definira ženu kao nomadski subjekt, odnosno kao subjekt u procesu tranzicije, koja započinje dolaskom postmodernog doba, a taj subjekt u pokretu vlastito mjesto pronalazi ulazeći u otvoreni konflikt s falogocentričnim statičnim i stabilnim subjektom.

Braidotti definira nomada kao vrhunskog jezičnog poliglota, a poliglota kao svestranog jezičnog nomada koji kontinuirano nastanjuje područja u kojima se prepliću različiti jezici i

\footnotetext{
119 Deleuze koristi termin psihički nomadizam kako bi njime okarakterizirao suptilno stanje duha, neku vrstu psihičkog progona ili bijega, ono što Jean-François Lyotard naziva „ničija zemlja“ (no-man's-land), a radi se zapravo o obliku otpora prema institucijama sustava. U poznatoj teorijskoj Raspravi o nomadologiji, Gilles Deleuze i Félix Guattari objašnjavanju kako je nomadizam zapravo fenomen intenzivnog putovanja u mjestu.
} 
izričaji (p. 22). Nomad jest, ističe Braidotti, jezični virtuoz. On razumije i govori tisuću jezika, poznaje svako skriveno značenje riječi i svaku moguću interpretaciju. Za njega riječi i rečenice nisu konačan oblik, već bezvremenski i bezprostorni simboli u neprekidnom gibanju, koji unutar različitih konteksta ostvaruju različita značenja:

\begin{abstract}
Poliglot prakticira svojevrsnu nenasilnu promiskuitetnost na međi različitih lingvističkih supstrata, odričući se svake pomisli na etnički i lingvistički puritanizam. Poliglotizam jest nenasilan otpor prema tiranskom režimu Jednog. Ne postoje materinji jezici. ${ }^{120}$ Samo jezični prostori koji služe kao početna točka. Poliglot ne posjeduje jedan prvi jezik, već mnoge linije tranzicije i transgresije. (p. 29)
\end{abstract}

Braidotti podsjeća kako se upravo unutar jezika konstituira subjekt. Jezik je simbolički kapital koji je kultura kroz stoljeća akumulirala. Krećući od Saussureove lingvističke teorije o arbitrarnosti znaka, odnosno jezika, Braidotti zaključuje da je upravo poliglot veliki meštar, univerzalni poznavalac intimnih i suptilnih veza među jezičnim znakovima i njihovim značenjima. Poliglot je, u tom smislu, prototip postmodernog subjekta koji ne traži da kroz jezik nužno kazuje, on dopušta da jezik govori njemu (p. 32). Nomadsko pismo, kako ga navodi Braidotti (p. 36-37), najčešće u doslovnom smislu i obilježeno zemljopisnim dislokacijama, karakterizira afinitete prema područjima gdje se vrijeme i prostor sad preklapaju, a sad gube, poput ratom razorenih područja, beskonačnih nenastanjenih pustinja, tamnica i zatvorskih ćelija, egzotičnih dalekoistočnih zemalja, ali i beskonačnih prostora svemira. Nomadsko se pismo protivi ideološkom puritanizmu. On je antiedipski odgovor usmjeren na „autoritativni režim tiranskih očeva“ (p. 37). Jezični nomad, ističe Braidotti, njeguje stil strukturalističkog bricolagea $^{121}$ kojem je glavno obilježje inter- i transdisciplinarnost, te ono što Deleuze definira kao deteritorijalizacija, odnosno postati nomadom ideja, premještati pojedine koncepte, poznate registre te kulturne i literarne običaje u neki novi kontekst i svrhu. Stil jezičnog nomada suprotstavlja se ustaljenom, rigidnom i formalnom akademskom institucionaliziranom jezičnom izričaju, a često je obilježen mnogobrojnim preklapanjima različitih jezičnih stilova i registara, približavajući se govornom, a ne pisanom jeziku (p. 58-60). Stoga je nomadska estetika uglavnom i usmjerena

\footnotetext{
${ }^{120}$ Julia Kristeva, Adriana Cavarero, ali i prethodno cijela lacanovska psihoanaliza, pokazali su kako materinji jezik u naravi ne postoji, kako jezici nose zapravo očev predznak, očev specifični registar. U tom smislu, svi se jezici svijeta već u prvotnom, „materinjem“ obliku na neki način prevode.

${ }^{121}$ Termin vezan uz Lévi-Straussovu strukturalnu antropologiju.
} 
na demistifikaciju književnog jezika, na rušenje političkih i kulturnih enklava, na uočavanje nejasnih oblika hegemonije i opresije.

Žena koja piše i živi u modernom zapadnom dijelu svijeta svakodnevno se suočava s konceptom poststrukturalističke utopije, u smislu nade u bilo kakvu mogućnost izlaza iz jednosmjernoga falogocentričnoga zapadnjačkog načina poimanja svijeta. Na zapadnoj je polutci žena koja piše u trajnom izbjeglištvu, bez vlastitog identiteta, bez vlastite domovine:

Kao žena, nemam domovinu. Kao žena, ne želim ikakvu domovinu. Kao žena, moja je domovina cijeli svijet. ${ }^{122}$

Taj koncept izbjeglištva prati gotovo cijelu neofeminističku teoriju, od Hélène Cixous, Parižanke židovskog porijekla rođene u Alžiru, preko Julie Kristeve, Bugarke nastanjene u Francuskoj, do Cavarero i Braidotti, talijanskih znanstvenica s američkim adresama. Braidotti, međutim, ističe kako ono što nomada razlikuje od izbjeglice jest manjak želje i nostalgije za stabilnom i konačnom domovinom. Nomad je subjekt u kontinuiranoj tranziciji, a njegove su tranzicije progresivnoga karaktera: „on je vektor deteritorijalizacije“123. Za razliku od književnika/ca u izbjeglištvu, pisaca i spisateljica imigranata, pa čak i postkolonijalnih autora i autorica, koji svi govore u obliku sjećanja i nostalgije o zatvorenim i zauvijek izgubljenim horizontima, koristeći prošlo svršeno vrijeme, asocirajući na zvuke „materinjeg jezika“, nomadski je pisac/spisateljica usredotočen na uzrok i posljedice, njegovo/njezino je vrijeme imperfekt, aktivno, dugotrajno i nesvršeno vrijeme kojim čvrsto uspostavlja vezu sa stvarnošću. On/ona odlučno se suprotstavlja svakom obliku totalitarizma, dominacije ili političkog nasilja, u Foucaltovim terminima on/ona predstavlja otpor kultu sjećanja, divinizacije, prihvaćanja i asimilacije. Nomad predstavlja visoko kritičku svijest, pogled kroz sadašnjost, direktno u budućnost: „,nomad ne daje niti uzima, on samo zamjenjuje“ (p. 47).

\footnotetext{
${ }^{122}$ Woolf, V. (1958) The Three Guineas. London: Penguin.

${ }^{123}$ Delleuze, G.; Guattari, F. (1986) Nomadology: The War Machine. New York: Semiotexte.
} 


\section{II. III. Teorija roda}

Judith Butler, teoretičarka feminističkog smjera unutar diskursa kritičke teorije, poststrukturalizma, odnosno općenito kontinentalne filozofije, intelektualka s prestižnog Sveučilišta Berkeley-California, jedna je od najutjecajnijih autorica s početka 90-ih godina. Njezina najpoznatija djela, Gender Trouble (1990) te Bodies That Matter (1993), snažno su utjecala na teoriju roda, odnosno na njezin dio poznat pod nazivom queer theory. ${ }^{124}$ Služeći se izuzetno sofisticiranim poststrukturalističkim i postmodernističkim teorijskim instrumentima, Butler u svojim tekstovima kritički razmatra Foucaultove teze o tjelesnosti i identitetu, te potvrđuje Kristevine navode o nemogućnosti definiranja identiteta. Dodaje, također, kako je ono što smatramo identitetom u potpunosti materijalizirano i udaljeno od stvarne prirode, a tvori ga niz društvenih konvencija poput jezika i raznih društvenih kodeksa. Prema mišljenju Butler (1990), ne postoje muškarac i žena, već niz društveno dominantnih obrazaca ponašanja prema kojima se svatko od nas određuje, odnosno svatko postaje ono što radi, a ne ono što jest.

Promatranje spola i roda kao dvije odvojene kategorije nastalo je izlaskom Drugog spola Simone de Beauvoir, u kojem autorica izriče slavnu krilaticu ,ženom se ne rađa, ženom se postaje“", te tako objašnjava da sve ono što se tradicionalno smatra ženskošću nije prirodno ni biološki determinirano, već je rezultat društvenih konstrukcija. Judith Butler, međutim, iznosi teoriju o performativnosti roda, ${ }^{125}$ koja upućuje na to da rod ne može biti stvar svakodnevnog izbora. Performativnost je praksa koja uspostavlja rod svojim neprestanim ponavljanjem, ona je, točnije, govorna praksa koja sprovodi ili proizvodi ono što imenuje. Koncept performativnosti u konačnici rezultira nadilaženjem kategorije subjekta. Naime, ,postajanje rodom“, ${ }^{126}$ u teoriji Judith Butler, ima nadasve semiološki predznak - ono označava nikad završavajući proces postajanja identitetom. U tom smislu, kategorija subjekta shvaćena je kao

\footnotetext{
124 Termin queer počinje se koristiti 90-ih godina na kongresima raznih humanističkih disciplina, a među prvima ga koriste Michel Foucault, Judith Butler te Teresa de Laurentis. Označava u naravi devijaciju od tradicionalizirane i institucionalizirane norme, a kreće od tzv. dekonstrukcije roda (po uzoru na Jacquesa Derridaa). Kao alternativu postojećim spolnim/rodnim identitetima, queer teorija predstavila je queer kao dodatni (ne)identitet, no ona ne predstavlja identitet samo kao kategoriju već kao proces neprekidnog „remećenja“ (Laurentis 1999, p. 104-106).

125 Originator je teorije o performativu filozof jezika John Langshaw Austin, koji je, uz Derridaa, Kristevu, Foucaulta, Lacana, Nietzschea te Lévi-Straussa, snažno utjecao na izrazito slojevit i minuciozan kritičkoteorijski rad Judith Butler.

${ }^{126}$ Proces inspiriran beauvoirovskim pitanjem ,rađa ili postaje“ te hegelovskom dijalektikom (odnos gospodara i roba).
} 
učinak performativnog procesa, kao specifičnog oblika semioze. Njome se supstancijalni subjekt u potpunosti negira, i kao epistemiološka i kao empirijska činjenica, a potvrđuje se isključivo postojanje ,učinka“ subjekta. Ukratko, identitet se, prema mišljenju Butler, nikada ne uspostavlja do kraja. Razne identitetske pozicije u znakovnom lancu obuhvaćaju cjelovitost subjekta, no on im uvijek izmiče, on je uvijek već označen i ne prestaje označavati dok cirkulira kroz razne diskurse.

Osvrćući se na teoriju Luce Irigaray, prema kojoj se jezik usvaja i razumije kao falogocentričan, te Monique Wittig, koja tvrdi kako je ženski spol jedini onaj predočen u jeziku koji spaja žensko i spolno, Butler istražuje načine na koje jezik gradi kategoriju spola. Prema Butler (1990) sam jezik proizvodi fiktivnu konstrukciju spola kojim se istovremeno podupiru oni režimi moći koje feminizam, navodno, pokušava destabilizirati, a veliki dio zapadnjačkih kulturnih praksi i društvenih normi proizvode i podupiru subverzivni diskontinuitet i nesrazmjer između spola i roda: „Feministička bi kritika morala razumjeti kako kategoriju žena, subjekt feminizma, proizvode i sputavaju one iste strukture moći preko kojih se teži emancipaciji“ (Butler 2000, p. 18). U tom smislu, politički sustav i njegovi zakoni izravno sudjeluju u diskurzivnom konstituiranju feminističkog subjekta kako bi njime opravdali autokratsku hegemoniju vlastitih struktura. Butler također analizira pojam ženski identitet unutar različitih povijesnih i kulturnih konteksta, te ističe kako se rodna obilježja uvijek križaju s rasnim, klasnim, etničkim, spolnim i regionalnim obilježjima, stoga je nemoguće izolirati rod iz kulturno-povijesnog i političkog konteksta (p. 19). Naime, muškoženska binarnost, poimanje svemira kroz prizmu suprotnosti, koju je već ranije osudila Hélène Cixous, prema mišljenju Butler tvore jedan izuzetno isključiv okvir koji razdvaja svu specifičnost ženskog identiteta od klasnih, rasnih, etničkih i drugih osi unutar kojih je prvotno i prirodno uronjen, iz kojih je izravno proniknuo:

\footnotetext{
Specifičnost ženskoga još je jednom potpuno dekontekstualizirana te analitički i politički odijeljena od konstitucije klase, rase, etniciteta i drugih osi odnosa moći koji tvore identitet [...] pretpostavljenu univerzalnost i jedinstvenost subjekta feminizma djelotvorno potkopavaju ograničenja predstavničkog diskursa u kojem funkcionira. (p. 20)
}

Glavnu nevolju u pogledu poimanja ženskog i muškog identiteta Butler vidi u shvaćanju odnosa između roda i spola. Naime, prvotna feministička nastojanja da odijele rod od spola trebala su poslužiti osporavanju tradicionalističkih psihoanalitičkih dogmi da je biologija naša 
sudbina, odnosno dok je spol biološki zadan i nepromjenjiv, rod je kulturalno konstruiran pojam te je o spolu u potpunosti neovisan: ,rod stoga nije ni posljedica spola, ni tako naizgled čvrst kao spol [...] Ako su rodovi kulturalna značenja što ih pretpostavlja spolno (sexed) tijelo, tada se ne može reći da rod proistječe iz spola“ (p. 21). Butler također upozorava kako se rod ne bi smio shvaćati samo kao kulturalno upisivanje značenja na prethodno dani spol, već rod mora označavati i onaj sustav proizvodnje kojim se oformljuju spolovi. Iz tog razloga, navodi Butler, rod nikako ne može biti kulturi ono što je spol prirodi. Rod je jednostavno kulturalno sredstvo kojim se spol proizvodi i uspostavlja kao nešto „preddiskurzivno“, kao ono koje prethodi kulturi, „kao politički neutralna površina na koju kultura djeluje“ (p. 22).

Butler u potpunosti negira ispravnost bilo kakvog oblika kulturnog i društvenog determinizma te opominje neke feminističke teoretičarke koje tvrde kako je rod kulturalna interpretacija spola, odnosno kako je rod kulturalno konstruiran. Jer ako je rod konstruiran, pita se Butler, bi li mogao biti drugačije konstruiran? Ili je njegov oblik nepromjenjiv? Uzimajući u obzir mogućnost da kultura, zajedno sa cijelim skupom njezinih pisanih i nepisanih pravila, konstruira rod, čini se da je rod ipak determiniran i konačan u svom obliku i svojstvima, u jednakoj mjeri u kojoj je to bio spol za biologiste. U takvu slučaju, ističe Butler, sudbinom ne postaje biologija, nego kultura (p. 23).

Nadalje, Butler opominje egzistencijalistička stajališta Simone de Beauvoir, poglavito jer se čini kako je za ovu autoricu postajanje ženom prilično nejasan proces, udaljen od prirodne prisile koja bi potekla od onog spolnog, koji leluja između čina u potpunosti ovisnog o volji i izboru pojedinca te kulturnih i društvenih preuvjetovanih konstrukcija. Nejasno je, ističe Butler, je li za Beauvoir rod uistinu slobodan odabir pojedinca ili odabir preuvjetovan kulturnim diskursom. Butler analizira i Beauvoirina stajališta o ženskom kao Drugom. Naime, Beauvoir sučeljava muški rod kao univerzalnu osobnost koja transcendira tjelesno (tako da su muški rod i univerzalna osoba jedno) sa ženskim rodom koji je određen upravo s obzirom na vlastiti spol, odnosno s obzirom na tjelesnu i materijalnu istancu. Butler tako ukazuje na Beauvoirino neispravno predstavljanje žene kao označenog-Drugog, kao negativa muškarca, kao nedostatka spram kojeg se definira muški identitet. Nasuprot takvom viđenju ženskog identiteta, Butler suprotstavlja teoriju Luce Irigaray, koja tvrdi kako ženski spol nije jedan, kako u tom prevladavajuće falogocentričnom jeziku žene čine ono nepredočivo: ,žene su spol koji se ne može misliti, jezična odsutnost i neprozirnost. U jeziku koji počiva na nedvosmislenom značenju, ženski je spol ono neograničeno i neodredivo“ (p. 24). 
Na tragu Irigaray, Butler ističe da je ženski spol upravo točka ,jezične odsutnosti“ (p.25), stoga ženski spol nije nipošto drugo ili nedostatak, kako tvrdi Beauvoir, definirajući tako negativno ženski subjekt, već je ženski spol onaj koji same uvjete predočavanja vješto izbjegava. S tim u vezi, tvrdi Butler, žensko nije oznaka subjekta, o ženskom se ne može teorijski misliti, jer ,ženski je spol subjekt koji nije jedan“( (p. 25).

Butler također upozorava na pomutnju unutar socioloških i filozofskih rasprava u pogledu definicije identiteta, odnosno uloge spolnog, zatim rodnog, obilježja, u konačnom oblikovanju strukture osobnosti. Prema njezinom mišljenju, osobe postaju spoznatljive tek kada dobiju rod „u skladu s priznatim mjerilima rodne spoznatljivosti“ (p. 30). Međutim, do određenoga logičkog diskontinuiteta dolazi kada se određene osobe, rodna bića, ne uspijevaju prilagoditi rodnim normama kulturne spoznatljivosti kojima se osobe prvotno definiraju. Tada, takve određene vrste „rodnih identiteta“ (p. 31), ne prilagođavajući se određenim normama kulture i društva, najčešće djeluju kao svojevrsni razvojni neuspjesi.

Dakle, identitet se, prema mišljenju Butler, osigurava prvenstveno kroz pojmove roda, spola i spolnosti, a stabilnost identiteta i njegovu spoznatljivost jamče koherentnost i kontinuitet između biološkoga spolnog određenja i kulturno konstituiranog roda. Društveni režimi moći, vođeni zakonima i normama rodne gramatike, oni su koji proizvode spolnu koncepciju identiteta ili, kako je Butler naziva, ,prisilnu konvencionalnu heteroseksualnu hegemoniju“ (p. 32). Pozivajući se na Monique Wittig, ${ }^{127}$ koja tvrdi da je muški spol u potpunosti neomeđen i stoga univerzalan, dok je ženski uvijek taj koji obilježava ono jednostrano spolno, ali i oslanjajući se na teoriju Luce Irigaray, ${ }^{128}$ koja smatra da žene ne mogu „biti“ i da se putem konvencionalnih predstavničkih sustava ne mogu predstavljati jer upravo su one „fetiš predstavništva“ (p. 32), nedokučiva razlika koja se ne može spoznati kao jednostavna negacija ili „drugo“, ${ }^{129}$ Butler naglašava da upravo jezik podupire onaj supstancijalni model roda, predstavljajući ga kao binaran odnos između dviju strana, muške i ženske. Ta ,gramatika binarnosti“ (p. 33), ističe Butler, djelotvorno prikriva jednoznačni i hegemonijski diskurs muškosti i falogocentrizma, zatomljujući ženskost kao mjesto subverzivne raznolikosti. Binarno regulirana spolnost, nastavlja Butler, potiskuje svu ljepotu i raznolikost spolnosti te je

\footnotetext{
${ }^{127}$ Wittig, M. (1983)»The Point of View: Universal or Particular? « u: Femminist Issues. sv. 3, br. 2, p. 64.

${ }^{128}$ Ce sexe qui n'en est pas un (1977).

${ }^{129}$ Kako Beauvoir prikazuje.
} 
svodi na služenje isključivo reproduktivnim ciljevima sustava prisilne heteroseksualnosti, a nestajanje kategorije spola i roda, slom prisilne heteroseksualnosti, mogao bi, prema Butler, donijeti istinski humanizam i oslobođenje od okova spola.

Čovjek je, dakle, svoj rod u mjeri u kojoj nije drugi rod, odnosno definicija nekog roda kreće se neminovno unutar institucionalno određenoga binarnog para. No, Butler napominje kako se osobna pripadnost nekom rodu kreće od mogućega spolnog obilježja i opredjeljenja, preko psihičkog osjećaja i poimanja sebstva, do različitih izražaja tog istog sebstva, od kojih je najistaknutiji, ističe Butler, onaj spolne žudnje:

\begin{abstract}
Izjava žene „osjećam se kao žena“ ili izjava muškarca „osjećam se kao muškarac“ pretpostavlja da ta tvrdnja ni u jednom slučaju nije besmisleno suvišna. Iako bi moglo izgledati da nije problematično biti dana anatomija, iskustvo rodne psihičke dispozicije ili kulturnog identiteta smatra se postignućem. Zato je „osjećam se kao Žena“ istinito onoliko koliko i zazivanje određujućeg Drugog Arethe Franklin „S tobom se osjećam kao prirodna žena“. To postignuće zahtijeva razlikovanje od suprotnog spola. (p. 35)
\end{abstract}

Nadalje, Butler ovaj heteroseksualni ugovor između muškarca i žene promatra kroz prizmu jezika te osuđuje sam jezik kao instituciju koja proizvodi i širi sustav prisilne heteroseksualnosti, koja nastoji ograničiti proizvodnju identiteta duž osi heteroseksualne žudnje (p. 39). U tom smislu, nadovezuje se na Monique Wittig, koja tvrdi kako moć jezika zapravo podređuje i isključuje žene, kako ih marginalizira te oslabljuje njihovo djelovanje. ${ }^{130}$ Ovako nepovoljan položaj žene unutar polja jezika Butler objašnjava putem lacanovske, odnosno postlacanovske, reformulacije Freuda, opet ponajviše se oslanjajući na tekstove Luce Irigaray. Naime, proces stvaranja subjekta, onog koji kazuje, u lacanovskoj psihoanalizi razlikuje se u odnosu na spol; muški subjekt proizvodi Zakon Oca, zakon koji zabranjuje rodoskvrnuće, tako da muški jezični položaj prolazi kroz proces individualizacije, ali i heteroseksualizacije utemeljene na ovoj zabrani. S druge strane, žensko nije obilježeno kao subjekt, već kao znak nedostatka označenog simboličkim, ono je odstupanje koje otvara prostor spolne razlike. Ipak, zaključuje Butler, i muška i ženska pozicija uvedene su putem prohibitivnih zakona koji proizvode zatim kulturno prepoznatljive rodove. Identitet je tako svojevrsna umjetna konstrukcija, nastala na temeljima neprirodnog procesa potiskivanja i zabrane (p. 41).

\footnotetext{
${ }^{130}$ Wittig, M. (1984) »The Trojan Horse« u: Femminist Issues. sv. 4, br. 2, p. 68
} 
Butler također analizira uspostavu vlastite rodne i spolne spoznatljivosti suprostavljajući ontološke pretpostavke zapadne metafizike i pitanje ,što biće jest“ Lacanovoj teoriji jezika unutar koje očinski zakoni dominiraju i strukturiraju jezik te unutar koje nešto dobiva oznaku „,bića“ jedino unutar strukture označivanja koja je simboličko-predontološka i koja nas dovodi do pitanja „kako je biće ustanovljeno“: „Nema, dakle, istraživanja ontologije per se, nema pristupa biću bez prethodnog uvida u 'biće' Falusa, autorizirajućeg označivanja Zakona koji spolnu razliku uzima kao pretpostavku vlastite spoznatljivosti““ (p. 55). Putem dvaju uzajamno isključivih pozicija lacanovskog simboličkog poretka, ,imanja“ Falusa (pozicija muškarca) te „bivanja“ Falusom (pozicija žene), Butler također tumači uspostavljanje dijalektičkog odnosa dvaju identiteta, muškog i ženskog. „Biti“ Falusom, u lacanovskom smislu, znači zapravo biti označiteljem žudnje Drugog, odnosno znači biti njegov objekt, znači predstavljati i održavati mušku heteroseksualiziranu želju. Na taj način žene održavaju mušku moć i supremaciju, potvrđujući time muškarčev identitet: „Lacan jasno govori da moć ima ta ženska pozicija neimanja, da muški subjekt koji 'ima' Falus zahtijeva od tog Drugog da potvrdi i da tako 'bude' Falusom u njegovu proširenom smislu“ (p. 55). Upravo je ovom međusobnom ovisnošću uzajamno isključivih pozicija ,imanja“ Falusa i „,bivanja“ Falusom simbolički poredak stvorio kulturno spoznatljive rodove. ${ }^{131}$ Lacanovska psihoanaliza potvrđuje da subjekt nastaje, da ,jest““, nakon što zauzme položaj samoutemeljujućeg označitelja unutar jezika. No, to se događa isključivo i jedino putem prvobitnog procesa potiskivanja svih onih incestnih želja povezanih s majčinim tijelom. Butler ističe da muški subjekt samo prividno označava, odnosno stvara značenja. Njegova prividna autonomija služi zapravo prikrivanju primarnog procesa potiskivanja, a bez ženskoga potvrđujućeg znaka ,jest“, kojim biva zamijenjeno majčino tijelo i koje otvara mogućnost povratka prvim ugodama, muška moć i autonomija slabe i nestaju: „Bivanje Falusom tako je uvijek bivanje za muški subjekt, koji nastoji ponovno potvrditi i povećati svoj identitet priznavanjem toga bivanja za“ (p. 56). U tom smislu, zaključuje Butler, žene su ključan emblem i obećanje održanja muške moći, pomoću njih očinski zakon proširuje svoju moć djelovanja i konstruiranja funkcije muškarca. Žena je, dakle, sam Falus. Ona je nedostatak koji afirmira i utjelovljuje „imanje“ Falusa, a to žena postiže, kako Lacan objašnjava u Značenje Falusa, ${ }^{132}$ procesom maskiranja.

\footnotetext{
${ }^{131}$ Međusobna ovisnost tih dviju pozicija priziva hegelovsku strukturu neuspjele recipročnosti između gospodara i roba, odnosno neočekivanu ovisnost gospodara o robu kako bi refleksijom uspostavio vlastiti identitet (Butler 2000, p. 55).

${ }^{132}$ Die Bedeutung des Phallus (1966).
} 
Naime, Lacan opisuje položaj žene kao onog kojim se prikazuje nedostatak, stoga se one moraju, na neki način, maskirati, odnosno intervenirati u vlastiti izgled i vlastitu pojavnost (Lacan, 1983a). Upravo će ova funkcija maske, ističe Butler, dominirati procesom spolne i rodne identifikacije. Ona će predstavljati moguće sredstvo kojim će se sama ženskost najprije uspostaviti, njome će se najvjerojatnije prikriti druge biseksualne tendencije i mogućnosti koje bi mogle uništiti „pokaznu heteroseksualiziranu ženskost“ (p. 58). Tradicionalni psihoanalitički pristup ženskost temelji na isključenju muškog. Procesom potiskivanja i isključenja stvara se binaran odnos, odnosno dva zasebna rodna identiteta: „No, rezultat jest da je identitet uvijek već inherentan u biseksualnoj dispoziciji koja je potiskivanjem razlomljena u svoje sastavne dijelove“ (p. 64). Zabrana stvara temeljnu podjelu spolnosti, no ta je razdjelnica zapravo umjetna i lažna, napominje Butler. Binarno ograničenje spolnosti pokazuje kako kultura ne slijedi nakon biseksualnosti koju navodno potiskuje: „ona čini matricu spoznatljivosti kroz koju postaje misliva sama primarna biseksualnost" (p. 64). Da bi se, dakle, heteronormativan sustav održao, on jednostavno mora održati svoju esencijalnu muškost odnosno ženskost, iako, tvrdi Butler, one su uvijek u nekom procesu nedovršene, one su zadatak koji nikada nije ispunjen. Rod kao takav uvijek predstavlja novi zahtjev koji treba potvrditi muškost odnosno ženskost. Činjenica da heteroseksualnost uvijek iznova sebe konstituira predstavlja dokaz da je ona stalno ugrožena, to jest da zna za mogućnost svog razobličenja.

U knjizi Bodies That Matter ${ }^{133}$ (1993) Butler potvrđuje sve ono prethodno napisano u Gender Trouble (1990), stavljajući težište na lingvističku dimenziju konstrukcije identiteta, odnosno roda. Rodna svojstva, srž identiteta, prema mišljenju Butler, oblikuju upravo riječi. One ocrtavaju i postavljaju granice, one uspostavljaju materijalnost subjekta, „on“, „ona“, „mi“. Lingvističkim pravcem usmjereni smo na razmišljanje o tome ,što netko jest“”, a jezične norme i zakoni, prije svega zapadnjačke filozofije i metafizike, ukazuju na međusobne odnose spola i roda „dok sam matriks rodnih odnosa kao da ima prvenstvo u odnosu na riječ ljudsko biće“" (Butler 1996, p. 10).

${ }^{133}$ Butler, J. (1966) Corpi che contano. I limiti discorsivi del „sesso “. Feltrinelli: Milano. 
Zaključak cjelokupnoga teorijskog opusa Judith Butler jest da je rod kulturni izraz prirodnog spola, odnosno spol je zapravo efekt roda, a prirodnost spola samo je naizgled preddiskurzivna kategorija koja proizlazi iz binarnih struktura jezika. 
II. DIO

ORIANA FALLACI: ANATOMIJA ŽENSKOG PISMA 


\section{SEKSUALNO I TEKSTUALNO}

\section{I. TEKST I KONTEKST}

\section{I. I. Antiedipski bricolage}

Oko imena Oriana Fallaci otvarale su se brojne polemike. Jedni su je glorificirali, drugi pak prezirali. Ambiciozna, pametna, hrabra i pomalo ekscentrična, baš kao i njezini radovi, nije prolazila nezapažena. Ulazeći u dominantno muški svijet novinarskog i spisateljskog, Fallaci se godinama borila s predrasudama široke javnosti, s uglednim kritičarima i kolegama novinarima, a naposljetku i sa samom sobom. Usprkos brojnim kritikama, koje je zbog svog antitradicionalističkog, neformalnog i otvorenog načina pisanja doživljavala, njezina su se djela, prevedena na mnoge jezike u brojnim izdanjima, u mnogočemu pokazala ispred svoga vremena.

Razmatrajući razmišljanja nekih kritičara, u pogledu formalne specifičnosti i literarne kakvoće Fallacinih djela, ustanovljuju se mnoge nedoumice i predrasude. Naime, kritičari avangarde, često opterećeni formom i kanonom, smatraju da su njezina djela žanrovski nejasna i nedefinirana, nedovoljno stilistički i metrički ambiciozna, kontaminirana kolokvijalnim i regionalnim leksikom, uobličena rascjepkanom i kaotičnom sintaksom (GattRutter 1996, p. 175-176).

Fallaci se oduvijek odupirala tradicionalnoj zapadnoj žanrovskoj klasifikaciji. Njezin novinarski rad oblikovao je neka prva iskustvena saznanja i utabao put kasnijim literarnim djelima, stoga u onoj mjeri u kojoj se unutar novinarskog osjeća prisutnost literarnog, u gotovo jednakoj mjeri unutar literarnog osjeća se ono novinarsko, reportažno i stvarno. GattRutter ističe kako su Fallacini tekstovi u procesu neprekidne žanrovske metamorfoze (p. 9). Ponekad se iz oblika reportaže prelazi u oblik znanstvenog eseja, iz znanstvenog eseja u dnevnik, iz dnevnika u roman. Ta „demokratizacija žanrova“, naglašava Gatt-Rutter (p. 146), temeljna je osobina Fallacinog opusa, a do maksimalnog izražaja dolazi u djelima koje karakterizira element tzv. otvorene tekstualnosti, jedne od gradivnih komponenti književnog novinarstva, poput Gli antipatici, Intervista con la storia, Se il sole muore te Quel giorno sulla luna. Reportaže Oriane Fallaci, objašnjava Gatt-Rutter, obiluju literarnim elementima, a 
formalno neopterećeni pitki i prozračni romani ukazuju na autoričinu sposobnost da uspješno žonglira „u međuigri koja nastaje između kulturoloških razlika i onoga što ljude izjednačava“ (p. 9).

S tehničkog i formalnog aspekta, Fallacini se tekstovi predstavljaju kao svojevrstan postmoderni bricolage, što prema mišljenju nekih autora (Spinazzola 1990, pp. 225; 250-252) dovodi u pitanje estetske parametre te granicu literarnog i paraliterarnog. Njezina su djela neobičan spoj talijanske novele i verističkog romana s elementima moderne drame i New Journalisma.

Razmatrajući sociološki aspekt estetike, teoretičari jezika i kulture Bourdieu (1993, p. 190) i Corsini (1974, p. 20-24) napominju kako je izuzetno problematično i nezahvalno odrediti egzaktnu pripadnost i literarnu kakvoću nekog djela, ističući kako je proizvodnja kulturnih dobara ponajviše uvjetovana omjerom trenutne ponude i potražnje na tržištu, što osobito otežava određivanje stvarne, neutralne, vrijednosti književnog teksta.

I Roman Jakobson (1987, p. 42-45) iskazuje veliku sumnju u mogućnost konačnog definiranja i razlikovanja literarnog od paraliterarnog, odnosno neliterarnog, jer, kako tvrdi, oznake i vrijednosti koje sudjeluju u konačnoj implementaciji estetskih funkcija nisu nepromjenjive i uvijek uniformne, tako da čitavo žanrovsko područje može u jednom trenutku biti klasificirano kao ekstraliterarno, a u nekom drugom kao intraliterarno.

Gerard Genette (1991, pp. 91; 95; 151) cjelokupnu problematiku literarne kakvoće dodatno pojednostavljuje, tvrdeći kako je sva fikcija, zajedno s poezijom, sama po sebi unutar nekog literarnog „načina“, odnosno žanra, stoga su rasprave o literarnim, paraliterarnim i neliterarnim tekstovima rasprave o ukusima. Također, Genette smatra kako su žanrovske granice umjetno konstruirane i u naravi ne postoje, one se prirodno neprekidno prepliću i gube, a svako je pisanje, zaključuje ovaj autor, literaran čin.

Talijanski teoretičari Ferretti (1988, p. 73-91) i Ceserani (1986, p. 165), slažući se s Bourdieuom i Corsinijem oko nemogućnosti određivanja stvarne neutralne vrijednosti kulturnog proizvoda, odnosno uzročno-posljedične povezanosti sociokulturološkog i političkog miljea s trenutnim tržišnim okolnostima, dodatno naglašavaju kako je za tzv. hibridne žanrove, poput onih Oriane Fallaci, egzaktnu granicu literarnog i paraliterarnog nemoguće odrediti, a literarna je kakvoća, u tom slučaju, najčešće pitanje konačnog estetskog užitka. 
Pune svijesti o tehničkim i formalnim razlikama koje postoje između novinarskog pisanja i pisanja fikcije, Fallaci se nerijetko suočava s poteškoćama pri nastojanju da te dvije vrste pisanja u potpunosti odvoji. Novinarstvo od nje traži lingvističku transparentnost i jasnoću, kao i sposobnost detaljne i minuciozne opservacije i deskripcije. S druge strane, pisanje romana izvlači na površinu sve ono što novinarska struka sputava i ograničava: visok senzibilitet, potpunu spontanost, snažnu kreativnu energiju te izraženu imaginativnu sposobnost „da poput spužve apsorbira život i ispljune ga ponovno u obliku ideja“ (Fallaci 1990, p. 309). Konačan rezultat ovako kompleksnog i višestrukog preplitanja novinarskog i literarnog pristrani su i, s lingvističkog aspekta, izuzetno slojeviti novinarski tekstovi, odnosno literarni tekstovi koji, u semiotičkom smislu, predstavljaju elemente otvorene tekstualnosti, interpretativne kooperativnosti i jezične demokratičnosti. $\mathrm{S}$ žanrovskog stajališta, nastaju tako neobični amalgami fikcije i dokumentarističkog, subjektivnog i objektivnog, literarnog i novinarskog.

Usprkos velikoj popularnosti i utjecaju koje je Fallaci uživala diljem svijeta, činjenici da je 70-ih godina uvrštena među najutjecajnije žene Amerike ${ }^{134}$ (Ostellino, 1990) i da je za svoje romane, prevedene na brojne jezike različitih kontinenata, dobila značajne književne nagrade, poput Bancarella Prize za roman Niente e così sia (1970), Premio Viareggio za Un uomo (1979) te nagradu Hemingway za kapitalno djelo Insciallah (1990), neki kritičari njezin uspjeh smatraju rezultatom dobro pogođenog trenutka i osjećaja trenutne potrebe tržišta, umanjujući literarne, formalne i estetske vrijednosti njezinih tekstova (Marabini, 1979), proglašavajući ih ,popularnom kitsch literaturom“ (Guarini, 1979), bez jasno artikuliranog formalnog i žanrovskog opredjeljenja (Spinazzola, 1990), oskudne stilističke kvalitete i sintaktičke cjelovitosti (Milani, 1971).

Razmatrajući tehnički aspekt Fallacinih djela, uzimajući u obzir sve manjkavosti i neodređenosti koje joj neki kritičari pripisuju, čini se da je riječ o jednostavnom odustajanju od faličkih estetskih kriterija, od institucionaliziranih literarnih vrijednosti. Njezini tekstovi, nosioci iskustvenih saznanja ženske supkulture, obilježeni su snažnom fuzijom politike i estetike, seksualnog i tekstualnog. Odlučna u namjeri da njezin glas, kao i glas „malih“ i potlačenih, čuju svi slojevi društva, neformalnom, elegantnom i kristalno transparentnom retorikom Fallaci uspješno artikulira ono gotovo neizrecivo (Gatt-Rutter 1996, p. 21-22).

${ }^{134}$ Veći dio svog života i karijere Fallaci je provela u New Yorku, od mladenačkih godina, pa sve do smrti, kada je posljednje počivalište odlučila pronaći u rodnoj Firenzi. 
Izuzetno dinamičan i vrlo subjektiviziran pristup pojedinačnim temama omogućuje kompleksnu i slojevitu psihološku karakterizaciju likova, kao i ideološku procjenu okolnosti. Oprezno krojeći ritam i foničnost vlastitih zapisa, pazeći na leksičku i sintaktičku izmjenu, Fallaci se, u naravi, približava retorici slobodnoga govornog čina, lišenoj svih okova i utega zapadnjačkih falogokratičnih predrasuda i kritika.

Česta sintagmatska subverzija prati i onu paradigmatsku, a orijentalistička, kulturnorelativistička, percepcija transkulturalnih granica sam čin pisanja vraća u položaj marginalnog, odnosno disidentskog, i različitog. Izražena nomadska estetika, kojom uspješno iskazuje jasan otpor političkom i lingvističkom puritanizmu, ozbiljno je usmjerena na demistifikaciju kulturnih elita, na otpor kultu zapadnjačkog umjetničkog i estetskog jednoumlja, a potpun tjelesni i gotovo fiziološki pristup tekstualnom mediju ${ }^{135}$ ostavlja snažan karnalni otisak ženskog glasa, prema mišljenju nekih kritičara (Aricò 1998, p. 4-5) ključnog elementa uspjeha njezinih tekstova.

Fallaci je istodobno i novinarka i književnica, ističe Santo L. Aricò. Njezini su romani bogati novinarskom istinom i jasnoćom, a novinarski članci, strukturirani poput književnih djela, nadilaze sva očekivanja novinarske struke (p. 4). U svakom djeliću njezinog teksta, zaključuje Aricò, krije se otisak iskustva Oriane Fallaci. Njezina intelektualna, politička i filozofska putovanja nalaze se u svemu što piše. Ona je glavni akter, autor, režiser, scenarist, pripovjedač i lik svojih djela, uspjeh kojih je, upravo zbog emotivnog i psihološkog autoričinog otiska, u najvećoj mjeri zajamčen (Poirier, 1971).

\footnotetext{
${ }^{135}$ Osobito izražen u djelima Penelope alla guerra (1962) te Lettera a un bambino mai nato (1975).
} 


\title{
I. I. II. Fallaci o/u ženskom i ženstvenom
}

Iako je mnogim ženama poslužila kao inspiracija, ženskim se pitanjem kao političkom opcijom Fallaci dugo odbija baviti, a s velikom odlučnošću odbacuje i sve one podjele koje impliciraju biološke razlike, nazivajući ih „seksističko biheviorističkim pseudoznanstvenim pokušajima“"(Carrano 1978, p. 83).

Na ponudu glavnog urednika renomiranog talijanskog časopisa Europeo 1960. da izradi niz fotoreportaža o ulozi i položaju žena autorica izjavljuje:

\begin{abstract}
Koliko mi je god moguće, uvijek izbjegavam pisati o ženama ili o problemima koji se tiču žena. Ne znam zašto, to mi stvara nelagodu, čini mi se nakaradno. Žene nisu neka izdvojena fauna $\mathrm{i}$ ne razumijem iz kojeg bi to razloga one trebale biti promatrane, osobito u novinskim člancima, kao zaseban slučaj, poput sporta, politike i vremenske prognoze. Svevišnji je proizveo muškarce i žene kako bi zajedno postojali i od tog trenutka činili si ugodu, tako da ophođenje prema ženama kao bićima s drugog planeta, na kojoj se razmnožavaju partenogenezom, smatram besmislicom. (Fallaci 1961, p. 7-8).
\end{abstract}

$\mathrm{U}$ jednom od mnogih razgovora $\mathrm{s}$ talijanskom spisateljicom Patrizijom Carrano Fallaci odgovara na pitanje „što znači biti žena“ jednostavnom konstatacijom „,isto što znači biti muškarac“. Prema njezinom mišljenju, biti žena, kao i biti muškarac, podrazumijeva njegovanje moralnih i duhovnih vrijednosti, borbu, no ne nužno i pobjedu (Carrano 1978, p. 97-98). Žene su ovisne o muškarcima, kao i muškarci o ženama, tako da se istinska revolucija žene bez podrške i pomoći muškarca ne može do kraja sprovesti, smatra Fallaci.

Fallaci je oduvijek koračala putevima rezerviranima za muškarce, pritom nimalo ne prikrivajući svoju ženskost i ženstvenost. Vodila je vrlo intimne, dugotrajne i iscrpljujuće razgovore s tada najpoznatijim svjetskim vođama i moćnicima. Suočila se s iranskim vođom Ruhollahom Khomeinijem, izazivajući ga svojom iskrenom i slobodnom zapadnjačkom Ženstvenošću, poigrala se s libijskim diktatorom Muammarom al Gaddafijem, javno dovodeći u pitanje nacionalnu sigurnost (Franks 1981, p. 19), izazvala je diplomatski skandal između Indije i Pakistana, koristeći Alì Bhuttovu naivnost (Fallaci 1974, p. 221-240), ponizila je etiopskog cara Hailea Selassija (p. 373-388), te objavila kompromitirajuće članke o vođi Palestinske oslobodilačke fronte Yasseru Arafatu (p. 145-160).

Svim ključnim događajima, svim prekretnim političkim, ali i znanstvenim, trenucima postmodernog doba, Fallaci je osobno svjedočila, bilježeći i jasno o njima govoreći. 
Pratila je prvu svemirsku utrku za odlazak na Mjesec, boravila u NASA-i, ručala s američkim predsjednicima, svađala se s njihovim savjetnicima. Okusila je Vijetnamski rat „hrabro noseći svoju ženskost i ženstvenost među vojnicima“ (De Stefano 2015, p. 150), putovala u Afriku ne bi li svjedočila strašnom genocidu Ruande i Ugande, dizala svoj glas među mladim revolucionarima i studentima u Mađarskoj i Meksiku, provela ključne ratne godine u razorenom Beirutu. No, njezina ženskost i ženstvenost, ističe De Stefano (p. 150151) uvijek putuju s njom i njezin su nerazdvojan dio. ${ }^{136}$

Fallaci je uvijek samostalno i samouvjereno nastupala i djelovala, osjećajući različitost, ali nipošto inferiornost. Njezino shvaćanje i prihvaćanje komparativnih prednosti ženskog i ženstvenog odrazili su se tako i na tekstove koje je s velikim strpljenjem krojila. Proučavajući psihodinamiku autoričine tekstualnosti, dekonstruirajući i analizirajući retoričke elemente, moguće je zaključiti kako su sintaktičke i semantičke, sintagmatske i paradigmatske osi u velikoj mjeri natopljene snagom i energijom libidne ženstvenosti. Sposobnost afektivne fuzije, visoka razina intuicije, mogućnost subverzivne percepcije i ekspresije stvarnosti, te tjelesno i fiziološko stapanje autorskog $J a$ s tekstom u nastanku, odnosno fuzije fikcije i autobiografskog, intratekstualnog i ekstratekstualnog, kao i izuzetno intimna povezanost fluidnog i mnogostrukog jezika i govora s osjetom dodira, ukazuju na potpuno prirodan, gotovo neraskidiv, odnos ženskog, ženstvenog i tekstualnog. Fallacinom decidiranom opiranju radikalnom političkom feminizmu, osobito početkom i sredinom 60-ih, kao i jasno izraženom stajalištu o heterogenoj različitosti, s vremenom se pridružuje lingvistički otpor zapadnjačkom kultu Falusa. Sazrijevajući, kao autorica, ali i kao žena, (ne)svjesno se priklanja poststrukturalističkim retoričkim strategijama, semantičkim i sintaktičkim krojenjima bez preliminarnih sažetaka, na posve nepredvidiv i spontan, ženski i ženstven, način, osluškujući tekst, dopuštajući mu da je vodi i određuje smjer. ${ }^{137}$ Takvo snažno opiranje lingvističkom totalitarizmu i kulturnoj hegemoniji zapadnjačkog Logosa rezultirat će tekstovima s elementima lingvističke deteritorijalizacije, kronološki neuređene sintagmatske i paradigmatske silnice, te fragmentirane, odnosno nelinearne, naracije, kojima se, ujedno, pridružuje i vrlo izražen afinitet prema nomadskoj estetici, ${ }^{138}$ egzotičnim nomadskim

\footnotetext{
${ }^{136} \mathrm{U}$ jednoj od mnogobrojnih bilješki, koje je vodila u Vijetnamu, među popisom raznih cjepiva, poput kolere i žute groznice, nalazi se popis kozmetičkih obaveza: frizer, najlonke, suknja, torbica, nokti (De Stefano 2015, p. 150-151).

${ }^{137}$ Tekstualna strategija koju Adriana Cavarero (1997) pripisuje ženskom i ženstvenom.

${ }^{138}$ Braidotti, R. (2002).
} 
bespućima i beskonačnim svemirskim prostranstvima, prostorima izvan Zakona i jezika Simboličkog.

Fallaci njeguje proces lingvističke demokracije. Zaokrećući i pomičući jezične granice, neprekidno dovodi u pitanje pojam identiteta i subjektiviteta, autora i autorskog glasa. Njezin osnovni strateški alat konkavni je speculum, ${ }^{139}$ mise en abîme, kojim vlastiti tekst morfološki produbljuje i otvara, čini ga živim tkivom podložnim mnogostrukim hermeneutičkim istraživanjima. Za nju je pisanje prirodan i sinkroniziran prijepis slobodnoga govornog čina, prostor u koji unosi vlastitu sebe, vlastita razmišljanja i stavove, progovarajući tzv. glasom tijela. ${ }^{140}$ To joj izravno omogućuju novinarska iskustva i uporaba zvučne vrpce, što djelima pridodaje neobičnu intermedijalnu dimenziju. Prisutnost zvuka, živoga glasa, unutar pisanog teksta osposobljuje formalnu inhibiciju jezičnih zakona i potiče izlazak iz rigidnih okova grafičkog. ${ }^{141}$ Živi glas postaje tako osnovna karakteristika njezinih djela, jer, pišući, autorica prvenstveno osluškuje i govori, čuje i pretvara. Fallacino pismo posjeduje tako snažnu akustičnu, fiziološko-foničnu, dimenziju, što u konačnici čini nejasan prijelaz pisanog teksta $u$ spontani govor. Bihevioristička retorika slobodnoga govornog čina, oslobođena formalnih okova i predrasuda, jednostavno cijepa i fragmentira psihoanalitičku granicu tekstualnog, čineći ga fluidnim i prirodnim.

Spontani govor, sa svojim specifičnim interpunkcijskim stankama, izraženom intonacijom, ritmom, tonalitetom i leksičkim odabirom, izvirući izravno iz najdubljih slojeva psihe, u užoj je vezi s tijelom i spolnošću, što u Fallacinom slučaju ukazuje na jasnu prisutnost ženskog pisma, ${ }^{142}$ a ženska i ženstvena tekstualna strategija, obavijena elementom dodira, zvuka i tekućeg medija, prededipskim elementima iz kojih nastaje život, ${ }^{143}$ u potpunosti stapa tijelo i glas, glas i tekst, neutralizirajući sintaktičke i semantičke granice, rušeći falogocentričan sustav vrijednosti.

\footnotetext{
${ }^{139}$ Irigaray, L. (1974).

${ }^{140}$ Cixous, H. (1975b).

${ }^{141}$ Gatt-Rutter (1996) ističe kako je u Fallacinim tekstovima slobodan govor zarobljen unutar granica pisanog (p. 12).

${ }^{142}$ Écriture féminine (Cixous, 1975b).

${ }^{143}$ Irigaray, L. (1977).
} 


\section{I. III. Retorika slobode}

Oriana Fallaci dijete je talijanskog Pokreta otpora ${ }^{144}$ i kao djevojčica od svega četrnaest godina u njemu aktivno i sudjeluje. U obitelji Fallaci najvažnija je dogma oduvijek bila otpor režimu i diktaturi, otpor svim vrstama i oblicima tiranije, nasilja i hegemonije, a čežnja i borba za slobodu, kako to i sama autorica u odrasloj dobi često ističe (Aricò 1998, p. 19), bila je najstarija obiteljska tradicija.

Orianin otac, Edoardo Fallaci, upisan u stranku socijalista od svoje sedamnaeste godine i teško ozlijeđen od strane talijanskih fašista 1923., inzistira da njegova najstarija kći ${ }^{145}$ sudjeluje u logističkom vodstvu antifašističkih operacija. Rat i ratna zbivanja za mladu Orianu ubrzo postaju svakodnevica: „Odrasla sam u ratu. Otkad sam djevojčica nisam vidjela drugo osim rata, nisam čula drugo osim rata“ (De Stefano 2015, p. 17). Obitelj Fallaci živjela je vrlo skromno. Oriana i njezine sestre odrastaju u oskudnom i nesigurnom okruženju: „Kao djevojčica bila sam stručnjak za glad, hladnoću i strah“( (p. 18), izjavila je Fallaci mnogo godina kasnije na jednom skupu održanom u Njemačkoj.

Godine 1943., nakon pada Mussolinijevog režima, te 1944., nakon oslobođenja Firenze od strane Saveznika, za Orianu sve se mijenja i u njezin život ulaze mladi partizani, ${ }^{146}$ osobe koje će zauvijek obilježiti njezin pogled na svijet, ugraditi joj vrijednosti koje će kasnije, kao odrasla osoba, dalje njegovati: „Sve ono što jesam, sve ono što politički shvaćam, ja jesam i ja shvaćam zahvaljujući pokretu otpora“ (p. 8), prisjeća se autorica vremena kada je kao dijete, jureći na biciklu, raznosila manifeste i programe socijalističke stranke.

\footnotetext{
${ }^{144}$ Talijanski Pokret otpora (tal. Resistenza italiana/ Resistenza partigiana/ Secondo Risorgimento) zajednički je naziv za sve pokrete otpora koji su djelovali protiv nacifašizma od rujna 1943. do travnja 1945. i smatra se klicom neovisne Republike Italije. Najviše pripadnika ovog pokreta borilo se u redovima komunističkih brigada Garibaldi, brigadama Pravda i sloboda liberalnih socijalista, te socijalističkim brigadama Giacomo Matteotti, a nešto manji broj u redovima brigada demokrata i monarhista. Najintenzivniju aktivnost pokret je bilježio na sjevernome području Italije, u podnožju Alpa, Apenina i oko doline rijeke Po, odnosno na prostorima njemačke okupacije. Procjenjuje se da je tijekom djelovanja pokreta poginulo oko 50000 boraca od ukupno 80000 registriranih. Osim Talijana, pokretu otpora pridružili su se i razni ratni zarobljenici, zatočeni u Italiji u to vrijeme, poput Hrvata, Srba, Čeha, Rusa, Ukrajinaca, Nizozemaca, Španjolaca, Grka, Poljaka, Britanaca, Amerikanaca i Nijemaca dezertera iz Wehrmachta. Nakon rata, oko 35000 žena dobilo je, unutar pokreta, priznato pravo boračkog statusa. Iako im nije bilo dozvoljeno pridruživanje partizanskim jedinicama na prvim linijama bojišnice, ostavile su snažan utjecaj na razne druge, logističke i organizacijske načine.
}

${ }^{145}$ U obitelji Tosce i Edoarda Fallacija rodile su se tri djevojčice: 1929. najstarija Oriana, četiri godine kasnije Neera, te 1938. Paola. Godine 1964., nakon što su djevojke već odrasle i postale žene, obitelj odlučuje usvojiti djevojčicu iz sirotišta. Elisabetta postaje njihovo četvrto dijete, mezimica starijih sestara.

146 Jedne hladne noći u studenom 1943. Edoardo Fallaci dovodi kući dva mlada vojnika s kojima se Oriana brzo zbližava. Vojnici djevojčici pripovijedaju priče o ratu i slobodi. 
Fallacin ratni put i borba za slobodu započinju tako u talijanskom Pokretu otpora, a nastavljaju se, i nikada ne okončavaju, gdje god je bilo potlačenih, zaboravljenih i marginaliziranih. Kao mlada novinarka putuje uvijek u nepristupačna, ratom devastirana, područja. Gura se među naoružane revolucionare i živi svoju ratnu svakodnevicu na prvoj liniji bojišnice.

1956. godine započinje revolucija u Mađarskoj. Sa svojih tek navršenih dvadeset i sedam godina odlučuje ju izravno pratiti. Aldo Santini (1990a) ističe kako je upravo Mađarska revolucija događaj koji je usmjerio njezinu novinarsku karijeru, pokazao joj put kojim će se dalje kretati. 23. listopada 1956. Budimpešta ustaje protiv komunističkog režima. Istodobno, Fallaci kreće prema Austriji ne bi li posjetila mađarske izbjegličke kampove i među prvima ostvarila komunikaciju s ranjenim vojnicima. Ganuta i užasnuta onime što čuje i vidi, intenzivno bilježi svaku izgovorenu riječ vojnika i civila, pokušavajući što uvjerljivije prenijeti njihova bolna iskustva u pisani medij: „Tko je još kadar cijeniti površnost i ignorirati agoniju jednog umirućeg naroda, neka dođe ovdje u Beč i neka se osvjedoči“. ${ }^{147}$ Mađarska je revolucija, objašnjava Santini (1990a), pomogla mladoj novinarki da shvati kako pisanjem sudjeluje u borbi za slobodu, kako je novinarstvo njezina prilika.

Nakon nešto mirnijeg američkog intermezza, tijekom kojeg autorica, nezadovoljna režimom kapitalističkog konzumerističkog društva izobilja u kojemu se sloboda i blagostanje podrazumijevaju, neprestance istražuje mogućnosti novoga odlaska u nemirna i nesigurna ratna područja, uslijedit će odlazak u samo središte najvećeg pakla na zemlji, u Vijetnam. U studenom 1967. ona i njezin fotograf Gianfranco Moroldo stižu u Saigon. Nakon kratkog posjeta glavnome stožeru francuski joj kolega novinar, François Pelou, muškarac koji će ubrzo imati jednu od najznačajnijih uloga u njezinom životu, predlaže rizičan vojni kamp Dak To. Uzbuđena i počašćena, oblači vojnu uniformu, potpisujući da prihvaća odlazak na vlastitu odgovornost s naputkom američkoj ambasadi o mjestu ispostavljanja njezinog tijela u slučaju pogibelji: „Oriana je bila lavica, spremna na sve“ (Pelou u: De Stefano 2015, p. 137), ističe Pelou mnogo godina kasnije.

Fallaci je karijeru vrsne ratne reporterke izgradila upravo u Vijetnamu. Uz pomoć Peloua izbrusila je zanat do apsolutnog savršenstva. U svojim se člancima najčešće osvrće na patnje

${ }^{147}$ Fallaci, O. (1956) Ho vissuto in Ungheria l'ultima notte di libertà. Europeo, br. 46., 11. studenog, p. 30-33. 
nevinih civila te na agresivne američke intervencije u kojima pogibaju žene i djeca. ${ }^{148} \mathrm{U}$ ratu je, kao uvijek, na strani slabijih, na strani onih koji jedino slobodu traže. Fallacin nedvosmislen, uvjerljiv, često i brutalan način pisanja i izvještavanja ubrzo postaje prepoznatljiv među kolegama, koji njezin rad sve više poštuju i cijene, tako da je glavni urednik Europea proglašava njihovim službenim ratnim izvjestiteljem (p. 148).

4. travnja 1968. godine ubijen je Martin Luther King i afroamerička populacija prosvjeduje diljem američkih gradova. Fallaci se, na poziv Europea, odmah upućuje da cjelokupnu novonastalu situaciju poprati uživo. Ostaje u SAD do ožujka 1969., a potom se, žudeći za novim ratnim iskustvima, odlučuje vratiti u Vijetnam, ovaj put u njegov Sjeverni dio. Prateći delegaciju žena komunistica ${ }^{149}$ na Sjeveru ostaje dvanaest dana, u društvu dviju prevoditeljica, koje ju, ističe, prate poput sjene: „Brzo sam shvatila da ovdje neću moći raditi kao u Saigonu, u toj slobodi koju ti Amerikanci pružaju čak i kada o njima loše pišeš“ (p. 154). Ovo je razdoblje u kojem stvara mnoge neistomišljenike i kritičare njezinih djela. U svim tadašnjim člancima neprestano kritizira komunistički režim Sjevernog Vijetnama, čime si priskrbljuje etiketu, koju joj talijanska ljevica nadjenjuje, filoameričke konzervativne novinarke. Iako vrlo brzo postaje poznata kao nepodobna novinarka, to je ne sprječava da Indokineski rat poprati do njegovog samog kraja.

1970. godine američke trupe bombardiraju Hanoi i ulaze u Kambodžu. Ostavši osupnuta onime što čuje i vidi, sastavlja čitav niz brutalnih i nekonvencionalnih ratnih reportaža, govoreći o ,zvjerstvu koje se širi poput karcinoma“ (p. 160). Od tog trenutka povratka više nema, zamjeraju joj i lijevi i desni: „Bila sam uistinu jedina novinarka, jedina, koja je pisala istinu o Hanoiu '69. I drugi su novinari bili i vidjeli isto što i ja, ali nisu to zapisali. I naravno, zbog toga sam kamenovana“ (p. 157). Uoči kraja rata, glavni državni tajnik Henry Kissinger održava brojne sastanke s vođama Sjevernog Vijetnama, a sve njihove susrete Fallaci pomno prati i zapisuje. Konačni mirovni sporazum potpisuje se u Parizu i nalaže američkoj vojsci potpuno povlačenje iz indokineskog područja, oslobađanje političkih zatvorenika, kao i slobodan prolaz Sjevernovijetnamaca u južni dio zemlje. Na vrlo otvoren, iskren i transparentan način Fallaci opisuje osjećaj bespomoćnosti i beznađa koji je snašao američkog

\footnotetext{
148 Najupečatljiviji članci iz tog razdoblja, koje je Europeo objavio 1968., jesu Le storie di Saigon (br. $5,1$. veljače, 1968a), te Sono tornata a Saigon in fiamme (br. 8, 22. veljače, 1968b).

${ }^{149}$ Čin koji je izazvao ujedno zgražanje i divljenje, jer je sjeverni dio Vijetnama oduvijek nerado otvarao vrata novinarima i neistomišljenicima (De Stefano 2015, p. 154).
} 
predsjednika i njegovog glavnog pomoćnika: ${ }^{150}$ „Kissinger dobro zna da je povlačenje bio njihov jedini izlaz. Zna i da su prihvatili sve ono što je narod Sjevernog Vijetnama tražio. Isto tako zna da će u roku od pet ili šest godina Saigonom vladati komunisti““ (p. 160). I nitko nije nimalo sumnjao da će se njezina, uvijek iskrena i vrlo precizna, predviđanja konačno i ostvariti. Vrlo brzo komunisti su preuzeli vlast nad Vijetnamom, no ne vrativši u zemlju mir i blagostanje, jer ,,predivni dok ratuju, komunisti postaju nesnošljivi čim pobjede“ (Fallaci u: De Stefano 2015, p. 161).

U vremenu u kojem je pratila vijetnamski sukob Fallaci je istodobno odlazila u druga ratna i nemirna područja, poput Južne Amerike, Bliskog i Dalekog Istoka. I upravo je to razdoblje njezine novinarske karijere obilježeno snažnim političkim angažmanom. U svim se tadašnjim tekstovima autorica uglavnom bavi pitanjem slobode, pravde i prava na različitost. Brazil, Meksiko, Bolivija, Čile, Peru, Libanon, Izrael, Vijetnam, Singapur, Trinidad, Bankok, Jordan, Bangladeš, Cejlon, Hong Kong, neka su od mjesta, zabilježena u njezinoj putovnici, koje je tada posjetila, o kojima je pisala.

Fallaci politiku shvaća vrlo ozbiljno. Smatra je glavnim oruđem u borbi za slobodu, mjestom dijaloga i demokracije: „Oduvijek sam se bavila politikom: pišući, djelujući, živeći. Odrasla sam u političkoj obitelji, odgojena sam u politici [ ... ] u demokraciju vjerujem čak i kada je to loša demokracija, ne mogu zamisliti drugi način da se vodi jedna država“" (p. 174). Kada je riječ o političkim i ratnim sukobima i okolnostima, za uredništvo Europea Fallaci je uvijek prvi izbor. U Aziji je kako bi svjedočila o indijsko-pakistanskim sukobima te sukobima Hong Konga i Crvene Kine, na Bliskom je Istoku kako bi popratila eskalaciju izraelskopalestinske situacije, u Južnoj Americi ulazi među prosvjednike ne bi li saznala nešto više od onog što ostali svjetski mediji prenose.

U svojim je tekstovima uvijek izuzetno anarhična i antidogmatična. Sve -izme, diktature i režime, sve političke krajnosti osuđuje kao neuspjele pokušaje. Duboko vjeruje u oslobođenje žene, ali ne podržava službeni feministički pokret, nostalgična je prema socijalizmu, ali ne vjeruje u njegovu stranačku stegu, nije komunistica, kao ni katolkinja, te ističe kako se ne moli ni u jednoj crkvi, ne trpi fašiste i desničare i smatra ih karcinomom društva, a sebe najčešće definira kao anarhičnog liberala i antifašista (p. 173).

\footnotetext{
${ }^{150}$ Fallaci u travnju 1975. piše Kissingeru otvoreno pismo, koje objavljuje Europeo (Fallaci, O., 1975a, Lettera a Kissinger dopo il suo fallimento, br. 14., 13. travnja, p. 32-33).
} 
1968. posjećuje Južnu Ameriku. Kontinent u kojem će, ističe Santini (1990b), mlada Fallaci dobiti svoje prvo „vatreno krštenje“. ${ }^{151}$ Te se godine svijet nepovratno izmijenio. Građanski prosvjedi, revolucije, ulančane studentske pobune, preplavili su gradove diljem planeta. 2 . listopada 1968. godine važan je dan za Ciudad de México. Na glavnome Trgu Triju Kultura ${ }^{152}$ studenti i radnici prosvjeduju protiv vlade. Nalazeći se na jednome od balkona s kojega govore vođe prosvjednika, nakon žestoke pucnjave vojske tijekom koje mnogi pogibaju, teško je ozlijeđena. ${ }^{153}$ Nakon kraćeg razdoblja oporavka u meksičkoj bolnici ${ }^{154}$ i nešto duljeg u Rio de Janeiru, nikad odlučnija, nastavlja pratiti tu kritičnu situaciju koja se širi duž čitavog južnoameričkog kontinenta. Tih je godina njezino stajalište u odnosu na SAD najkritičnije: „Nije li strašno, potresno, da najsretnija regija svijeta, najbogatija, najudobnija, zemlja u kojoj se postiglo ekonomsko blagostanje, ne zna odustati od monarha, diktatora, od kretena na vlasti, nego, naprotiv, uzgaja ovce i izvozi ih?“( (De Stefano 2015, p. 169).

Naoružana znanjem i ambicijom, kreće u pohod protiv južnoameričkih diktatora na vlasti. Nakon Brazila odlazi u Boliviju kako bi ispitala mladog francuskog intelektualca Régisa Debraya, osuđenog na doživotni zatvor jer se borio na strani revolucionara Che Guevare. Ulazi u Sveučilište La Paz, gdje studenti danima štrajkaju glađu, kako bi natjerali vladu da ispostavi tijela revolucionara ubijenih u Andama. Sve je vrlo osobno pogađa i odlučuje u ovim tragičnim događajima aktivno i sudjelovati. Nebrojeno puta razgovara s najistaknutijim svjetskim vođama, ${ }^{155}$ a svojim pikantnim člancima anarhičnih tonova, u kojima napada i ogoljuje vladajuće, pobuđuje interes široke međunarodne javnosti, potičući SAD da popusti.

Često ulazi u zabranjena i opasna područja, poput minskih polja, zatvorskih ćelija i tamnica, a povremeno pruža utočište odbjeglim političkim zatvorenicima. Biti novinar za nju znači upravo to: „Koje ti drugo zanimanje dopušta da bilježiš povijest u samome trenutku njezinog nastanka?“ (p. 171). Njezino se ime tih godina veže uz najintrigantnije i najčitanije novinske

\footnotetext{
${ }^{151}$ Santini, A. (1990b) In Messico Oriana ebbe il suo battesimo del fuoco. Oggi, 8. kolovoza, p. 38-42.

${ }^{152}$ Plaza de las Tres Culturas.

153 Tragediju je opisala u dva poznata članka iz '68: La notte di sangue in cui sono stata ferita (1968c, Europeo, 17. listopada, XXIV.42. 1197, p. 24-47.) i Città del Messico sconvolta da sei ore di violenta battaglia (1968d, Corriere Mercantile, 4. listopada, p. 1).

${ }^{154}$ Radi uplitanja u unutarnju politiku države, meksička ju je vlast prognala iz države i predala onoj brazilskoj (Fallaci, O., 1968e, Diario dal Messico. Europeo, 24. listopada, br. 43, p. 29-35).

155 Neki su politički zatvorenici oslobođeni zahvaljujući njezinom pregovaranju s američkim vođama.
} 
reportaže. Poštuje ju narod, jer se za njegov glas zalaže i bori, ali i vođe, jer od njezinih članaka uvijek strahuju.

Nakon Južne Amerike, u još jednom intervalu od Vijetnama, odlučuje se posvetiti izraelskopalestinskom pitanju. Taj „vrući krumpir“ nekoliko je puta u karijeri zaobišla, strahujući da bi mogla biti odviše pristrana:

\begin{abstract}
Židove poznaješ. S njima i zbog njih si patila. Odmalena, vidjela si ih na tisuće, milijune, uhićenih i ubijenih. Branila si ih, pomagala im, voljela ih. Nadala se da će imati mjesto s kojeg se mogu braniti. Svidjelo ti se da konačno uđu u svoju obećanu zemlju: jednu zemlju imenom Palestina. (p. 180)
\end{abstract}

U ožujku 1970. odlazi u Jordan te redovito šalje niz članaka na temu izraelsko-palestinskog sukoba. Susreće se s fedajinima, odlazi u kampove gdje se odgajaju budući borci ${ }^{156}$ i ostvaruje kontakt s vođom Palestinske Oslobodilačke Fronte, Yasserom Arafatom. ${ }^{157}$ Tijekom još jednog boravka u zemlji gdje su rat i neimaština svakodnevica, ubrzo shvaća kako obje strane, izraelska i palestinska, imaju razloga braniti ono što smatraju domom. Osjeća duboko poštovanje prema fedajinima, no istodobno je zgrožena islamističkom teokratskom vladavinom.

Njezin se ratni put nastavlja. 1972. odlazi u Indiju, potom u Pakistan, ne bi li zabilježila najvažnije činjenice vezane uz indijsko-pakistanski sukob. Susreće se s Indirom Gandhi, potom s Alì Bhuttom, izazivajući opći diplomatski skandal. ${ }^{158} \mathrm{U}$ mnogim aspektima Indijce smatra naprednim narodom, divi se snazi i ustrajnosti njihovih žena da istodobno sačuvaju tradiciju i ostvare slobodu i neovisnost. S druge strane, u muslimanskom Pakistanu osjeća se sputano i nerado ondje boravi.

Nakon Indije i Pakistana njezinu pozornost privlače Iran i Libija. Koncem 70-ih susreće se s Khomeinijem. Bio je to slučaj prve zapadne žene novinarke koja je uspjela ispitati poznatog vođu Islamske revolucije, čovjeka koji je srušio režim. Intervju s Khomeinijem, tijekom kojeg

\footnotetext{
156 Susret s islamističkim borcima opisan je u članku Tra i guerriglieri arabi, koji je Europeo objavio 26. veljače, 1970., u 9. broju (Fallaci, O., 1970a, p. 34-45).

${ }^{157}$ Fallaci, O. (1970b) L'intervista con Arafat. L'uomo che è a capo dei guerriglieri arabi. Europeo, br. 11, 12. ožujka, p. 23-29.

${ }^{158}$ Nakon što je Bhutto, revoltiran porukama Indire Gandhi koje mu je Fallaci „u dobroj namjeri“ prenijela, javno odgovorio indijskim vlastima (Fallaci, O., 1972., Bhutto risponde a Indira Gandhi. Europeo, br. 17, 27. travnja, p. 52-60).
} 
je Fallaci pokazala svu hrabrost i nadmoć oslobođene zapadne žene, ubrzo postaje najčitanije političko štivo tih godina diljem svijeta, a njezin otvoren i ekstravagantan način izražavanja objavljuju svi najpoznatiji svjetski časopisi. ${ }^{159}$

Par mjeseci kasnije odlazi u Libiju, na susret s Gaddafijem, još jednim diktatorom koji se, poput Khomeinija, vlasti domogao državnim udarom i već desetak godina odlučuje o sudbini zemlje. Fatalan se susret odvija u pustinjskom šatoru, te započinje, kao i uvijek, nizom kompromitirajućih i izuzetno polemičkih pitanja: o financiranju Crvenih brigada i spletkama unutar Fiata, o libijskom gostoprimstvu Idija Amina Dade, okrutnog vođe Ugande. Desetak godina kasnije izjavit će kako je razgovor s Gaddafijem, od prve do posljednje rečenice, bio otvorena bitka za intelektualnu nadmoć: „Taj je razgovor bio uistinu strašan“. ${ }^{160}$

Žudnja i strast, koje je Fallaci prema novinarskoj profesiji oduvijek osjećala, vodile su je u smjeru onih područja u kojima je narod priželjkivao samo jedno: slobodu. Za nju je sloboda pojam koji ona pretače iz svijeta stvarnosti u svijet fikcije, iz svijeta političkih i vojnih sukoba $\mathrm{u}$ prostor retoričkog $\mathrm{i}$ tekstualnog. Aktivno sudjelovanje $\mathrm{u}$ ratnim pohodima $\mathrm{i}$ vojnim intervencijama, svjedočenje ratnim strahotama, oblikovalo ju je i učinilo slobodnom i samosvjesnom. „Tvrdi ste. Izuzetno tvrdi. No, dopao mi se svaki trenutak našeg olujnog susreta, jer ste hrabra, lojalna i sposobna žena [ ... ] Nitko ne odlazi u rat kao Vi, pod bombe, samo kako bi dobio dobar intervju“, izjavio je izraelski general Ariel Sharon, nakon cjelodnevnog razgovora s autoricom 1982. godine. ${ }^{161}$

Sredinom osamdesetih Fallaci odlazi u Beirut. Libanonski rat bit će posljednji sukob kojem će još jednom osobno svjedočiti. U Libanonu je, priznaje, najviše plakala. Brutalni masakri civila, palež i pljačkanja bolnica, islamistički bombaši samoubojice, koji s takvom mirnoćom i pribranošću u trenutku ubiju na tisuće nevinih civila, ne daju joj noću oka sklopiti. Bilježi i razgovara s vojnicima, a iz tih se svjedočanstava rađa i njezino najopsežnije literarno djelo, roman Insciallah, kojim, kako kaže, ,pokušava izravnati račune s onim vječnim masakrom imenom rat“ (Fallaci 1990, p. 246). Kako bi došla do što povjerljivijih i što egzaktnijih informacija, boravi u šatorima među vojskom, odlazi u rizične vojne operacije, tijekom kojih

\footnotetext{
${ }^{159}$ Fallaci, O. (1979a) An Interview with Khomeini. New York Time Magazine, 7. listopada.

${ }^{160}$ Fallaci, O. (1988) Io e Gheddafi. E gli porsi il cappio perché si impiccasse da solo. Corriere della Sera, 24. travanj.

${ }^{161}$ Fallaci, O. (1982) Oriana Fallaci intervista il Generale Sharon. Europeo, br. 36, 6. rujna, p. 6-21.
} 
nerijetko iskače iz aviona ili se ukrcava na strmim i nepreglednim mjestima, riskirajući povrede, a često je malaksala i neispavana jer njezino tijelo boluje od tropskih bolesti. ${ }^{162}$

Do svoje šezdesete godine Fallaci živi i piše za one kojima je sloboda izražavanja oduzeta, za one čiji se glas ne čuje. Vlastito pisanje autorica doživljava kao životno poslanje, kao dužnost koju kao novinar i kao žena mora ispuniti. Njezina je retorika, prožeta iskustvima neimaštine i rata, obavijena čežnjom za slobodom. Baveći se, do krajnjih granica, pitanjima moralne, političke i psihološke slobode, kao i problematikom identiteta i pripadnosti, autorica duboko zadire u proces preispitivanja tradicije i patrijarhalnih dogmi, što se eksplicitno odražava i na formalnoj, sintagmatskoj, razini njezinih djela.

Fallacina orijentalistička, subverzivna i liberalno demokratična vizija svijeta u njezinim je tekstovima artikulirana neformalnom i upečatljivo jasnom retorikom slobodnoga govora, odnosno ženskoga glasa, kojim unutar teksta utiskuje svu ljepotu ženskosti i ženstvenosti. Njezin moralni i etički imperativ, koncept slobode, iskazuje se, kako sadržajno, tako i formalno, u mnogobrojnim člancima, reportažama, esejima i romanima, čineći čvrstu poveznicu, homogeni amalgam, autorskih ekstratekstualnih iskustvenih saznanja, egzistencijalističkih promišljanja, te intratekstualne zbilje.

\footnotetext{
${ }^{162}$ Malarije i žute groznice.
} 


\section{II. TIJELO I TEKST}

\section{I .II. I. Onkraj označenog}

Nakon prvog objavljivanja Drugog spola Simone de Beauvoir 1949., te prije masovnih feminističkih pokreta koji će uslijediti nakon godine 1968., na zapadnoj se hemisferi otvara razdoblje „velikog sna buržujskog feminizma“ (Gatt-Rutter 1996, p. 41). Iako je u većini zapadnoeuropskih zemalja fokus intelektualne zajednice usmjeren drugim pitanjima, u pojedinim se znanstvenim krugovima žensko pitanje suptilno provlači, većinom kao reakcija na nove prijevode Beauvoirinog bestsellera koji se u sve većem broju pojavljuju na tržištu.

Talijanski prijevod Drugog spola izlazi godine 1961., a to je ujedno i godina u kojoj Oriana Fallaci objavljuje svoju zbirku putopisnih članaka Il sesso inutile (Beskoristan spol), u kojoj također opisuje, kako i sam podnaslov knjige svjedoči (Un viaggio intorno alla donna ${ }^{163}$ ), jedno opširno putovanje u tajne ženskog i ženstvenog. Fallacino se djelo predstavlja kao skup od ukupno šest putopisnih eseja koji nastaju u razdoblju njezinog jednomjesečnog putovanja u bliskoistične i dalekoistočne zemlje (Tursku, Pakistan, Indiju, Maleziju, Hong Kong, Japan) te Hawaii i naposljetku New York, grad koji simbolizira zapadnjačke sociokulturne vrijednosti i koji će poslužiti kao referentna točka u sastavljanju zbirke.

Kada ju je u ljeto 1959. novopristigli Serrin nasljednik u Europeu, Giorgio Fattori, pozvao da učestvuje u egzotičnom putopisnom projektu otkrića ženskog položaja i utjecaja na Orijentu, zajedno s kolegom Duiliom Pallottelijem, fotoreporterom koji će je pratiti kroz cijelo trajanje putovanja, Fallaci se ozbiljno uvrijedila, ističući kako sebe smatra ozbiljnim novinarom, ${ }^{164}$ kojemu je zadaća baviti se ozbiljnim problemima i aktualnostima, te kako nema razloga da se ženama posvećuje zaseban i odvojen tekstualan prostor. No, Fallacin se rigidan i rigorozan stav glede ženskog pitanja u samo jednoj noći drastično promijenio. Noć uoči odluke o prihvaćanju poziva glavnoga urednika, svjedočeći suzama svoje mlade, lijepe i poslovno uspješne prijateljice, shvatila je kako su ,problemi muškaraca posljedica ekonomskih, rasnih, socijalnih i drugih kriza, no problemi žena posljedica su također, ili poglavito, činjenice da su žene“" (p. 9).

\footnotetext{
${ }^{163}$ Prev. Jedno putovanje oko žene.

${ }^{164}$ Un giornalista (uvijek naglašavajući maskulinizirani oblik imenice).
} 
U želji i namjeri da shvati razloge nastanka tako nepovoljnih socioantropoloških uvjeta za sveukupnu žensku populaciju, otiskuje se na jednomjesečno istraživačko putovanje.

U Turskoj susreće slobodne i emancipirane žene, oslobođene pripadnice ataturške revolucije, časnice, vojne pilotkinje i sutkinje. U Pakistanu njihovu najekstremniju suprotnost, podčinjene i muškarcu podređene žene koje, hodajući u svom zatvorenom purdahu, burkahu, djellabahu ili kulleu, ne vide i ne čuju dalje od jednog sitnog i uskog prozorčića u razini očiju koji im služi kao jedini kontakt s vanjskim svijetom. Za ženu koja dolazi iz zapadnog dijela Europe putovanje u muslimanski svijet predstavlja izuzetno traumatično iskustvo:

\begin{abstract}
Mnogo je sunca u zemljama islama: bijelog, nasilnog, zasljepljujućeg sunca. No muslimanske ga žene nikada ne vide: njihove su oči prilagođene sjeni kao oči krtice. Iz mraka majčine utrobe koračaju u mrak patrijarhalnog doma, iz kojeg nanovo koračaju u mrak bračne zajednice, a iz njega u mrak vlastitog groba. U tom putovanju u mraku, nitko ih ne primjećuje. (Fallaci 1961, p. 33)
\end{abstract}

Izbacuju je iz tramvaja jer nije ušla na ulaz namijenjen ženama, u banci joj odbijaju isporučiti novce jer ženama to nije dozvoljeno, no istodobno na ulicama tako rigidno i rigorozno ustrojenog sustava doživljava indiskretne poglede i dobacivanja. Fallaci primijećuje da se žene koje susreće u tradicionalnoj muslimanskoj odjeći ne osjećaju, ili nemaju instrumente kojima bi do te spoznaje mogle doći, sputano, potlaćeno ili izolirano. Mnoge na njezina pitanja o muškoj nadmoći i sociokulturnoj opresiji, zgražavajući se, okreću glavom i pružaju otpor, a uoči jedne svadbene povorke, na Fallacino pitanje tko je osoba obavijena u beskrajan sloj tkanine, skupina žena odgovara „Nitko, samo jedna žena!“‘ (p. 22).

Osjećajući se kao ,jedina žena koja je preživjela opći potop“(p.30), koja posjeduje vlastito prezime i osobnu iskaznicu sa slikom, koja razumije tu neobičnu zapadnjačku riječ ljubav, Fallaci napušta Pakistan i upućuje se u New Delhi, potom Kalkutu i Jaipur, gdje ostaje zapanjena napretkom koji su žene Indije ostvarile, ${ }^{165}$ ali istovremeno i neugodno iznenađena enormnim kontrastom koji perzistira između intelektualnog sloja i siromašne mase žena.

\footnotetext{
165 Dok su u europskim zemljama žene pravo glasa izborile između 40-ih i 70-ih godina (Francuska 1944., Italija 1945., Švicarska 1971.), u Indiji su to učinile 1935. Broj zastupnica u indijskom parlamentu 60-ih godina premašio je sve sjeverno i zapadnoeuropske države, kao i Rusiju i SAD. Broj liječnica u bolnicama znatno je veći u odnosu na broj liječnika, a u politici države žene su ostavile neizbrisiv trag; Indira Ghandi, gradonačelnica Kalkute Sarjini Naidu, veleposlanica Vijiayalakam Pandit, ministrica zdravstva i Ghandijeva savjetnica Rajumkari Amrit Kaur, žena koja je predstavljala Indiju 1928. na World Round Table Conference, samo su neka od važnih imena u politici Indije 60 -ih godina. Ženska moć očita je i u omjeru božanstava. Saraswati, Durga,
} 
I dok su žene intelektualnog miljea neovisne, snažne i uživaju svu moguću ravnopravnost, siromašnim ženama i dalje nije dopušteno ulaziti u javne prostore u odsutnosti muške pratnje, voziti se muškom stranom javnog prijevoza, pa čak ni pogledati muškarca u ravnini očiju. Ono što je osobito pogađa jest činjenica da je upravo ova najranjivija skupina žena, zbog problema prenapućenosti zemlje, podvrgnuta postupcima sterilizacije u državnim klinikama. ${ }^{166} \mathrm{~S}$ tim se ženama Fallaci susreće i razgovara, a $\mathrm{s}$ njihovim potresnim svjedočanstvima u mislima napušta Indiju te nastavlja putovanje prema Singapuru, Jakarti i konačnom novom odredištu, Kuala Lumpuru. Tamo susreće malezijske matrijarhe, vladarice džungle koje žive i opstaju od vlastitih privatnih posjeda i zemljoradnje, te koje se muškarcima služe isključivo u reprodukcijske svrhe, da bi se potom vratile svojoj ženskoj zajednici. ${ }^{167}$ Njihova djeca nose isključivo majčino prezime, a sav imetak i financijsku neovisnost nasljeđuju ženska djeca nakon majčine smrti. Iako ekonomski u potpunosti neovisne, boraveći isključivo u društvu vlastitog spola i samostalno iznoseći sav teret i svu odgovornost dječjeg odgoja i njege, autorica u iskrenost njihovog osmijeha duboko sumnja.

Kako joj viza za posjet Crvenoj Kini nije odobrena, Fallacina sljedeća postaja biti će Hong Kong i poneki posjet mostu koji razdvaja ta dva toliko bliska, a toliko različita svijeta. Jedan odan Mao Ce Tungu, drugi odan Chiang Kai Sheku i engleskoj kraljici Elizabeti II. Žene Crvene Kine, skrivajući svaki dio tijela širokom i dugačkom odjećom, slove kao najnepoželjnije žene Dalekog Istoka. No, kako im je komunistički režim omogućio određeni stupanj ravnopravnosti i pravne zaštite, u brak stupaju isključivo uz uvjet uzajamnog poštovanja i vjernosti. Žene Hong Konga slove kao najpoželjnije žene Dalekog Istoka. Ipak, usprkos zavodljivoj odjeći i naoko vrlo visokom životnom standardu, unutar bračne zajednice ne uživaju povlastice koje uživaju žene Crvene Kine. Muškarcima je zakonom odobrena poligamija, a razvod mogu zatražiti u bilo kojem trenutku, ako ustanove da je žena neplodna, ljubomorna ili pretjerano pričljiva. Nažalost, zaključuje Fallaci, žene Crvene Kine i žene Hong Konga nisu ipak toliko različite: „držeći kapke poluzatvorene, imaju jednako ljubomorno rastojanje kojim vam se suprotstavljaju ako im se pokušate približiti““(p. 129).

Luksam, Sasfati, Kali, zajedno s mnogim drugim božicama i božanstvima predstavljenima u dvospolnom obliku, stvorile su kult strahopoštovanja i ponosa indijske kulture.

${ }^{166}$ Do konca 1961. godine u Indiji je sterilizirano oko 100000 žena (De Stefano 2015, p. 89).

167 Matrijarhalne plemenske zajednice postoje i danas u nekim dijelovima Japana, Australije, Mikronezije, Malezije, Indije te Obale Bjelokosti (AA.VV., 2002., Hrvatska enciklopedija, Zagreb: Leksikografski Zavod Miroslav Krleža, p. 144.). 
I jedne i druge trpile su lomljenja i povezivanja metatarzalnih kostiju, postavljanja cervikalnih udlaga i agresivnih pektoralnih povoja, sve to kako bi se uklopile u estetski kanon i posljedično uspješno udale. I jedne i druge žive danas u gradovima gdje se riječ ljubav drži podalje od javnih prostora, gdje je bilo kakav oblik tjelesnog dodirivanja neprimjeren i neukusan čin, a ženski je preljub ozbiljno kazneno djelo. Ipak, ni u jednom dijelu svijeta nema toliko prostitucije koliko je ima u tom dijelu Azije.

Ozbiljno potresena tolikim suprotnostima i neutaženom žudnjom za istinskom srećom azijskih žena, Fallaci napušta Hong Kong i odlazi u Japan. U Tokiju, gradu u kojem je okusila sva duševna stanja koja jedna nepripremljena Europljanka može okusiti, razočaranje, ushit, srdžbu, oduševljenje i znatiželju (p. 167), susreće emancipirane proamerički orijentirane žene u uskim plavim trapericama i minijaturnim torbicama u kojima se nalazi kontracepcija, a malo dalje, u provinciji Kijota „misteriozna bića koja vlastiti život posvećuju ugodama tuđih muževa“ (p. 198), japanske gejše, žene koje posjeduju sve materijalne i socijalne preduvjete za uspostavu bezbrižnog i lagodnog života, no i za njih sreća ostaje nedostižan cilj. Gejše uživaju puni luksuz i protekciju, poštovanje i interes muškaraca, no izgarajući u beskonačno dugim i opsežnim školovanjima, dovodeći ljubavne vještine do znanstvenog maksimuma, spontani su im osjećaji i urođena ljudska želja za bliskošću u potpunosti ispražnjeni. Za razliku od kineskih žena, primjećuje Fallaci, japanske žene vlastitu seksualnost žive i doživljavaju na vrlo nesputan način, a broj od 35000 feminističkih udruga s ukupno 11,5 milijuna članica diljem zemlje, kao i 40 tvrtki u Osaki na čelu kojih su žene, te 11 zastupnica japanskog parlamenta, ostavljaju na autoricu snažan dojam. Ipak, zaključuje Fallaci, žene Japana nisu i ne mogu biti sretne, a to potvrđuje tadašnje posljednje izvješće Municipal Matrimonial Agency u kojem je zabilježeno da čak preko $80 \%$ Japanki iznad 30 godina ne smatra brak zajednicom ljubavi, već poslovnim i društvenim ugovorom (p. 204), a ljubav, kao i u većini zemalja Azije, ostaje luksuz za rijetke, od društva marginalizirane pojedince.

Posljednje pristanište, prije povratka u New York, havajsko je otočje. Zemlja „netaknutih i neiskvarenih žena krupnih bademastih očiju i kose crnije od mraka“" (p. 221), koje do dolaska bijelog čovjeka nisu poznavale bolesti i zabrane, ni osjećaje srama i krivnje zbog svog tamnoputog nagog tijela. No, dolaskom zapadnjačke kulture i zapadnjačkih ambicija i one su se izmijenile, a od one nekadašnje netaknute sreće i ljupke nevinosti ostao je samo, primjećuje Fallaci, cvijet u kosi i osmijeh za turiste. 
Sada već gotovo sigurna da istinsku žensku slobodu i sreću neće pronaći, jer očito je da one ne ovise uvijek o ekonomskoj moći ili socijalnom statusu, „ropstvo je zasigurno strašna stvar, ali je i pogrešno shvaćena sloboda!““ (De Stefano 2015, p. 93), Fallaci se budi u njujorškoj hotelskoj sobi s pogledom na Manhattan i njegove žene: „tisuće modernih žena koje vode rat protiv pokunjenih muškaraca; i bile su snažne, tako moćne i tako prokleto usamljene“ (p. 246). Iako posjeduju autoritet i utjecaj kakav je većini žena u svijetu u potpunosti nepoznat ${ }^{168}$, žene američkih gradova, zaključuje Fallaci, same su i usamljene (p. 247-248).

Fallacino je istraživanje u potpunosti posvećeno ženama. S obzirom na godinu prvoga izdanja, prirodu same teme te autoričino izvrsno poznavanje francuskog jezika, nerijetki su dovodili u vezu ovo djelo s Drugim spolom. No, usprkos nepokolebljivoj samouvjerenosti nekih kritičara, Fallacino se djelo u mnogočemu predstavlja kao autentično, autonomno i različito od onog Simone de Beauvoir. Naime, za razliku od Beauvoir, koja govori o „drugom spolu“169 i karakterizaciji ženske prirode, položaja i uvjeta u odnosu na muški spol, Fallaci, uvodeći sintagmu beskoristan spol ${ }^{170}$ i vraćajući se u kulturnorelativističku subjektnu promatračku poziciju, ${ }^{171}$ negira, na određen način, binarnu i bipolarnu opoziciju kao jedino moguće socioantropološko analitičko sredstvo. Također, s naratološkog aspekta, autorica se vrlo uvjerljivo udaljava od uobičajenog koncepta sveznajućeg pripovjedača čiji monolog odražava neupitnu i nedodirljivu stvarnost, te se, uz pomoć živopisnih i dramatičnih dijaloških konfrontacija, ${ }^{172}$ u Fallacinu slučaju, stvarnost tekstualno konstituira isključivo lingvističkim procesima, ${ }^{173}$ što dokazuju i prazni tekstualni prostori kojima autorica označava svojevrsnu autonomiju ostalih (ženskih) glasova prisutnih u tekstu, te njihovu podjednako važnu ulogu u kreiranju stvarnosti i stvaranju osjećaja slobode i autonomije teksta. I dok je Beauvoir isticala kako su isključivo društvo i socijalni poredak zaslužni i odgovorni za oblikovanje odnosa među spolovima, Fallaci ne misli tako. Neovisno o tome jesu li rođene i rasle unutar

\footnotetext{
${ }^{168}$ Tri četvrtine ekonomske moći države u njihovim je rukama, dominiraju kulturno-obrazovnim sustavom, imaju pravo glasa, no nisu dužne ratovati, u njihovoj prisutnosti muškarci skidaju šešir, no one ne i svoje rukavice ukoliko se on poželi rukovati s njom.

169 Čime se pretpostavlja postojanje „prvog spola“.

${ }^{170}$ Negiranje spolne i rodne hijerarhije.

${ }^{171}$ Said, E. (1978).

${ }^{172}$ Utjecaj New Journalisma.

${ }^{173}$ Barthes, R. (1968).
} 
demokratski ili komunistički uređenih država, muslimanskih ili hinduističkih sekti, primitivnih domorodačkih zajednica ili modernih postindustrijskih metropola, ,žene kao da se svojevoljno kreću u smjeru boli“ (Fallaci 1961, p. 254). Autorica ne negira postojanje niza socioantropoloških tabua temeljenih prvenstveno na uočavanju bioloških razlika među spolovima, poput tabua djevičanstva (p. 9-10), no čini se da, prema mišljenju Fallaci, ženski položaj submisivnog (seksualnog) subjekta, u zemljama poput Pakistana, Indije, Kine i Japana, djelomično jest određen sociokulturološkim ograničenjima, no djelomično i samovoljnom i samoodređenom subjektnom pozicijom koju žena zauzima, odnosno u psihoanalitičkim terminima, njezinim objektnim izborom (pp. 29-33; 55-56; 127-131; 210211). Također, očita društvena i religijska supresija nagonskog života u žena, kakva je prisutna u muslimanskim zemljama, Indiji i Kini, dovodi do pojačanog razvoja autodestruktivnih tendencija, pa i do razvoja „mazohističkih težnji“ (Freud 2006, p. 105) jer ženina oslabljena i umanjena libidna agresija, u konačnici, jest isključivo potisnuta agresija, u skladu s društvenim očekivanjima (Kofman 1985, p. 50-65). Uzrok, međutim, ženskog nepovoljnog položaja Fallaci ne traži u muškarcu ni u pravnim aktima različitih država koje je posjetila:

Draga moja, sve žene svijeta jednake su, bez obzira na njihovu rasnu, religijsku ili klimatsku pripadnost, jer ljudska je priroda jednaka. (p. 254)

Ženska priroda i seksualnost, zaključuje Fallaci, kompleksno su evolucijsko pitanje (p. 253255). Obje vrlo udaljene od naših svjesnih mehanizama, u neintegriranom prostoru jezika $i$ zakona, koji falogocentrični diskurs ne uspijeva obuhvatiti, u prostoru koji ,izmiče označiteljskom“ (Lacan, 2017), ${ }^{174}$ ostaju zagonetke za riješiti.

\footnotetext{
${ }^{174}$ Izmiče simboličkom poretku i onome koji označava (Falus). Radi se, dakle, o prostoru koji simbolički poredak ne uspijeva integrirati, koji ostaje izvan/onkraj prostora označenog. No, nemogućnost integracije u etablirani sustav znakova, odnosno izmicanje ženske seksualnosti i jezika označiteljskom, ne čini potonje „nefalične i nepotpune“ (Lacan, 2017), već kako Irigaray (1977), Cixous (1975b) i Cavarero (1987) ističu, različite i pripadajuće nekom Drugom prostoru i sustavu znakova.
} 


\section{II. II. Biseksualna tekstualnost}

Fallacino se promišljanje i zaokupljenost rodnim i spolnim pitanjima proteže na još nekolicinu tekstova, poglavito na one nastale tijekom 60-ih godina, kada je ova tematika uistinu zahvaćala cjelokupan politički kontekst. Ponekad neposredno, no najčešće neizravno, razmatrajući pitanja poput ženske tjelesnosti i identiteta, ženskog položaja u obitelji i svijetu rada, autorica razotkriva sliku tadašnjeg odnosa dvaju spolova. Njezino pisanje, svojevrsno priklanjanje avangardnim naratološkim strategijama, u vrlo uskoj vezi s tjelesnim, ali i psihičkim, nesvjesnim, mehanizmima, kojima biva otkrivena mnogostruka i različita priroda ženskog teksta, poprima oblik dvojnog, biseksualnog, libidnog procesa.

O takvoj se biseksualnoj tekstualnosti intenzivnije počelo govoriti i pisati tek koncem 70-ih, odnosno početkom 80-ih godina. To jungovsko i postjungovsko nasljeđe sustavnije je obradila Hélène Cixous (1977a), stvarajući preduvjete za njegovu egzaktniju primjenu u području lingvistike, psiholingvistike, te teorije teksta. Govoreći o biseksualnoj prirodi pisanog teksta inzistira se zapravo na uskoj povezanosti autorskog $J a$ s obje erotsko-emotivne polovice njegovog nesvjesnog prostora. ${ }^{175}$ Jezični fenomen, koji Cixous pripisuje prvenstveno tekstovima u ženskom autorstvu, nesvjesnu libidnu energiju, koja proizlazi iz arhetipskih iskustava, pretvara u tekstualan prostor kojim dominira koketiranje s različitim lokacijama sebstva ${ }^{176}$ te izražen afinitet prema pisanju kao karnalnoj materijalizaciji autorskog glasa.

Jedan od takvih tekstova autobiografski je roman Oriane Fallaci Penelope alla guerra (Penelopa ratu) koji autorica započinje pisati 1959., te konačno završava 1962. godine. Izuzetno avangardno i subverzivno prozno djelo za ondašnje sociokulturne i političke prilike, već od samoga naslova otkriva neobičnu zamjenu teza, odnosno rodnih uloga. Penelopa ne prihvaća svoj, prirodom i društvom određen, pasivan ženski položaj, te se odlučuje otisnuti na herojsko prekooceansko putovanje, iz tradicionalne i patrijarhalne Italije, u otvorenu i multikulturalnu Ameriku, čin koji je za talijansku književnost onoga doba predstavljao velik pomak. ${ }^{177}$

\footnotetext{
175 Jung, C. G. (1977f).

${ }^{176}$ Répéperage en soi (Cixous 1975b, p. 254).

177 Kod svih je poznatijih talijanskih romanopisaca, kako muških, tako i ženskih (poput Else Morante, Cesarea Pavesea, Alberta Moravije), statični ženski subjekt bio prikazan unutar hijerarhijski ovisne obiteljske zajednice. Umjesto inertne ženske žrtvene uloge, Fallaci se odlučuje za emancipiranu i slobodoumnu ženu kojom istodobno inaugurira i temu ekspatrijalizacije u talijanskoj književnosti.
} 
Penelopa ratu priča je o mladoj i ambicioznoj ženi koja prolazi svoja prva sentimentalna iskustva u gradu koji tek upoznaje. Ona je scenaristica koja stiže u New York kako bi se ostvarila među kolegama filmašima, a njezin pogled i tumačenje svijeta koji je okružuje, pogled je filmske kamere koja vrlo ekspresivno uočava sitne detalje. Filmsko će oko, zajedno s izuzetno dijaloški dinamičnom i transparentnom sintaksom, stvoriti jednu potpuno novu vrstu romana, na međi filma, kazališne drame, gotičkog romana i fantastične priče, obavijenog u ruho postfrojdovske obiteljske romanse.

Djelo obiluje autobiografskim podacima i autoreferencijalnim trenucima. Penelopa je, $\mathrm{u}$ naravi, mlada Oriana, koja sa svojih dvadeset i šest godina gubi nevinost na najčudnovatiji mogući način, iz prkosa, s homoseksualcem (De Stefano 2015, p. 101-102). Zamjenom teza Fallaci upućuje čitatelje na zaključak o promjeni odnosa među spolovima, odnosno na činjenicu da je snaga koju je nekad posjedovao muškarac sada u ženi i da se pojavila prava pomutnja rodnih uloga, jer kako bismo inače objasnili odnos ,žene-muškarca“ i „,muškarcažene“ (p. 103). Ta spolna ambivalentnost, natopljena autobiografskim iskustvima, proteže se cijelim romanom, a subverzija tijela i identiteta naglašena je na svim strukturalnim razinama. Prvenstveno je naglašena na onoj jezičnoj. Naime, napuštajući vlastitu domovinu i izuzetno patrijarhalan milje, Giovanna odlučuje, u skladu s mogućnostima koje joj nova zemlja pruža, skratiti vlastito ime u Giò, što u oba jezična prijevoda, kako onom talijanskom, tako i onom engleskom (Joe) zvuči, i jest, androgino. Naglašena je i na onoj simboličkoj, u prostoru zrcala:

\footnotetext{
Obukla se zadovoljna, barem jednom, svojim zrcalnim odrazom: hlače su izvrsno pristajale njezinim škrtim bokovima, muški joj je pulover pridodao jedan šaljiv ambivalentan ton, a zbog odsutnosti šminke činila se poput dječaka. (Fallaci 1962, p. 200)
}

Giò izlazi iz prededipskog imaginarnog svijeta mekih i nježnih kupola, plodnih i svježih vrtova (p. 29-16), te ulazi u svijet simboličkog. Tim svijetom, oslikanim faličkim motivima visokih ponosnih nebodera i krutih betonskih blokova (p. 29-20), vladaju jezični zakoni koji ju izvlače iz ženskog raja simbioze. Izlazak iz simbiotskog prostora (Italija), te ulazak u svijet jezika i kulture (Amerika), ulazak je u prostor zrcala koji obećava duševnu stabilnost i cjelovitost. No, kako lacanovska psihoanaliza tumači, ono što spoznajemo u zrcalu jest 
varka. ${ }^{178}$ Zrcalni odraz trenutak je uspostavljanja simboličkog i trenutak konstitucije identiteta, kao i odnosa s okolinom (Lacan 1983b, p. 9), a ono što Giò u zrcalu prepoznaje jest različito od one prve imaginarne identifikacije o kojoj je do tada, kao djevojčica, bila ovisna i koja ju je sablažnjavala:

\begin{abstract}
Svaki put kada bi prolazila pored ogledala nije uspjevala pobijediti znatiželju da vidi ono što ju na svijetu najviše zanima: sebe. I svaki bi put ostala razočarana: kao da je djevojčica nasuprot njoj bila neka druga osoba. (Fallaci 1962, p. 10)
\end{abstract}

U konačnici, nadilazeći prostor „označiteljskog“ (Lacan, 1983a) i koračajući prema prostoru onkraj jezika, Giò osvještava vlastitu seksualnost. Povezujući vlastite unutarnje veze, neovisne o „muškom imaginariju ženskog“ (Irigaray 1974, p. 20), prihvaća različitost ${ }^{179}$ kao sastavni dio vlastitog spolnog i rodnog identiteta.

U djelu se osjeća snažna prisutnost govornog čina. Naglašenim interpunkcijskim stankama, poput kazališnog se komada dijaloške sekvence ubrzano ritmički izmjenjuju, što doprinosi dramatičnosti i uvjerljivosti samoga teksta. Tehnika slobodnog govornog stila, kao i trenuci naracije u trećem licu jednine, koji međutim nikada nisu impersonalni ili distancirani već, nasuprot tome, nabijeni egzistencijalističkim promišljanjima, u funkciji su praćenja toka svijesti.

Fallaci, prerušena u pripovjedača, istinski se poistovjećuje s onime što piše. Razmišljanje o događajima koji su je potakli na stvaranje ovoga romana, ${ }^{180}$ pisanje kao označavanje tih istih događaja u nekom novom vremenu i prostoru gdje će ih s većom dozom podnošljivosti moći promatrati, te glas koji sve to fizički materijalizira, dodajući tekstu tjelesno ženstvenu dimenziju, postaju u konačnici jedno. Ta slojevita tekstualna strategija odraz je ženske varijabilne i mnogostruke biseksualnosti, o kojoj piše Hélène Cixous, ${ }^{181}$ a u Penelopi dolazi do maksimalnog izražaja. Giò (Fallaci) nimalo ne strahuje od Drugog (Autre) u sebi, naprotiv, ona dopušta da joj se dječačić (efebo, p. 200) iz zrcala približi i oslobodi prostor zagušljivog

\footnotetext{
${ }^{178}$ Meconnaissance (Lacan, 1949), trenutak edipske krize i međusobnog sukoba naših psihičkih registara.

${ }^{179}$ Différance (Derrida, 1967).

${ }^{180}$ Ljubavni brodolom i prvi gubitak djeteta koncem 50-ih (De Stefano 2015, pp. 75-82; 103-105).

${ }^{181}$ Cixous, H. (1975b).
} 
homogenog matriksa, prostora jednoznačnih monolitnih narativnih i interpretativnih strategija.

Penelopa ratu, kako i sam naslov knjige ukazuje, opire se konzistentnom linearnom i realističnom načinu pripovijedanja. Prije svega, roman ne posjeduje egzaktne vremenske oznake, a nagli vremenski skokovi u funkciji su praćenja i oponašanja skokova svijesti. U konačnici, takav će sustav narativnih amplituda stvoriti u čitatelja osjećaj ne samo vremenske, već i prostorne beskonačnosti teksta. Intencionalno ili kazualno Fallaci kao da odbija fiksirati događaje za tekstualni medij. Odupirući se metafizici prisutnosti, te iskazujući afinitet prema oniričkim i snažno metaforičkim elementima, autorica se približava nomadskoj tekstualnoj strategiji, ${ }^{182}$ čije je glavno obilježje upravo deteritorijalizacija, a uzimajući u obzir i činjenicu da je bildung glavne junakinje okosnica romana, čitav bi niz toposa mogao biti shvaćen kao prikaz duševne, odnosno psihičke, topografije, poput beskrajno širokih i mračnih njujorških ulica na čijem se kraju nalazi nebo plavije nego ikad ili od straha, poput divova, skamenjenih nebodera, kroz koje se nazire zalazak neuobičajene roza boje (p. 29). U takvom imaginarnom platonskom, gotovo utopističkom, ${ }^{183}$ vremenskom i prostornom raskoraku, prostoru koji vješto izmiče cenzuri, inverzija spolnih i rodnih uloga te biseksualna i homoseksualna ljudska priroda, kao da s većom lakoćom prodiru u tekst.

S tehničkog je aspekta vrlo izražena uloga gotičkih, odnosno fantastičnih elemenata, poput pojava utvare (p. 51-52), zvuka crkvenih zvona u trenutku delikta (p. 233), prizora mrtvog fetusa u bočici s alkoholom (p 234-235), te ubojitih kirurgovih ruku punih nabreklih vena ( $\mathrm{p}$. 233). Gotički elementi, zajedno s fantastičnim i oniričkim krajolicima, odupiru se geometrijski jasnoj tekstualnoj strategiji i vode roman u smjeru nepoznatog i enigmatskog (unheimliche). O takvoj je literarnoj maniri pisao Tzvetan Todorov u Uvodu u fantastičnu književnost. ${ }^{184}$ Naime, Todorov opisuje klasične gotičke elemente i njihovu ulogu unutar teksta, klasificirajući ih u nekoliko različitih kategorija, poput karakterističnih gotičkih toposa, zazornih prikaza mrtvih bića, zloglukih nagovještaja ili neizbježnih proročanstava i sudbina, s osobitim naglaskom na učinak zazornog, ${ }^{185}$ kao glavnog pokretača tekstualnog tkiva: „Mrtvi

\footnotetext{
${ }^{182}$ Braidotti, R. (1994).

${ }^{183}$ U smislu izvan označenog.

184 Todorov, Tz. (1972), Einführung in die Fantastische Literatur, München: Hanser.

185 Termin zazorno (njem. unheimliche, eng. uncanny) dolazi iz frojdovske psihoanalize. Teoriju zazornog Freud objavljuje 1919. godine, a veže je uz pojavu neurotskih poremećaja, odnosno anksioznih stanja. Naime, ono što
} 
su ponekad više živi od živih. I ubijaju one žive“ (p. 17). Gotički element zazornog u Fallacinom je romanu usko povezan $\mathrm{s}$ metaforičkom funkcijom osjeta dodira, zvuka i vodenog medija, sva tri u službi karakterističnog ženskog pisma u vremenu i prostoru prededipskog. Narativni pokretač romana označen je elementom vode, simbolom majčine utrobe. Naracija započinje kratkim prizorom iz djetinjstva, majčinim suzama koje pucketaju i pršte padajući na vruću peglu. Taj prizor glavnu junakinju u potpunosti sablažnjava:

\begin{abstract}
Od djevojke u ogledalu dopadala joj se samo kosa jer je bila svijetla i zbog nje je zaboravljala da pripada jednoj zemlji gdje žene imaju crnu kosu, poput njezine majke, ne znače ništa, poput njezine majke, plaču, poput njezine majke. Kao djevojčica, vidjela je majku kako plače. Glačala je košulje i plakala, a suze su šuštale pržeći se na toplome, ostavljajući bijele mrlje kao da su kapi vode, a ne suze. No, onda bi i mrlje izblijedile, kao da njihova bol nikada nije postojala. Od tog trenutka prisegnula je sama sebi da nikada neće glačati košulje i nikada neće plakati: „Nikada, Giò!““ ponovila je na glas. (p. 11)
\end{abstract}

Suzama ispire bol i homoseksualac Richard, najslabija karika ljubavnog trokuta. Konstantno emotivno rastrojen, istinski nesretan i odlučno neodlučan, zaklanja se u zonu prededipskog, u sigurnost majčine utrobe. Suze klize niz njegovo lice u trenucima emotivne i fizičke bliskosti s glavnom junakinjom, pokazujući svu nemoć i fragilnost njegove ličnosti, svu nedozrelost i impotentnost duha i tijela: ,poput djeteta koje je zgriješilo, ne znajući zašto, i sad se pribojava kazne“ (p. 78). Njegovu prikrivenu ženstvenost, hipersenzitivnost i duševnu nestabilnost, Fallaci simbolički oslikava apokaliptičkim opisom Niagarinih slapova, u kulminaciji samoga romana. U tom veličanstvenom i zastrašujućem vodenom bezdanu, u kojemu se zvuci prajezika i nemoćan krik galebova prelijevaju u jedno, Richard pokušava pronaći utočište (p. 180). Šum vodene oluje, koja gura, čisti i nosi sve pred sobom, vapaj poludjelih galebova i ,te oči pune vode koje zapravo nisu voda već plač“ (p. 183), nose određenu katarktičku simboliku. Pod okriljem najčudesnije snage prirode, u srcu moćnih slapova, Richard ispovijeda svoje grijehe, shvaćajući da ga ona ne može čuti, ali nadajući se da će ga razumjeti (p. 183-184).

je pojedincu u infantilnoj dobi familijarno i poznato (heimlich), no iz nekog razloga svijesti neprihvatljivo i nelagodno, stoga potisnuto, u odrasloj dobi biva revidirano i iznjedreno na površinu, u obliku nepoznatog, točnije nekad poznatog, a sada potisnutog, stoga stranog i zazornog (Freud, S. (1919), »The Uncanny«, u: Collected Works of Sigmund Freud, (1955), Vol. 17., London: Hogarth Press, p. 217-252). 
Suze klize niz obraz i naoko površne Francuskinje Martine, dok pripovijeda o tužnoj sudbini pokornih domaćica (p. 233). Obraćanje Martine u drugom licu jednine, dok guta suze i dim cigarete, obraćanje je Oriane Fallaci ${ }^{186}$ :

\begin{abstract}
Izgubih malog čovjeka. I izgubih i mog malog boga [ ... ] ali ne umire se zbog očaja. $\mathrm{S}$ očajem se jede, pije, spava, i jednoga se jutra dižeš i shvaćaš da je s očajem završeno i da se ožiljak više i ne vidi. (p. 235)
\end{abstract}

Još jedan gotički simbol koji autorica u romanu povezuje s elementom vode jest pljusak majčinih laganih ritmičkih koraka koji dopiru s tavana (p. 75). Taj fantastičan zvukovni prizor, koji se ponavlja u trenucima fizičke bliskosti glavnih likova (pp. 75; 82; 228), nanovo predstavlja patološki odnos majke $\mathrm{i}$ djeteta zarobljenog $\mathrm{u}$ imaginarnom prostoru prededipskog: „I s tavana pljušti, kao iz slavine koja propušta, zvuk koraka [ ... ] gotovo kao da ona koja korača očekuje nekog tko kasni, no mora doći“" (p. 82-83). Majčini koraci opominju i čupaju subjekt iz beznadnog pokušaja prelaska u svijet simboličkog, vraćajući ga u simbiotski položaj nikad zadovoljene žudnje. ${ }^{187}$ Majčina kiša koraka, poput goleme i moćne hobotnice, preplavljuje sve zidove prostorije, sav zrak koji ljubavnici udišu, sve misli koje se kroje u njihovim glavama (p. 83). Obavija ih, steže, lomi i privlači lagano k sebi, u emotivni pakao prededipskog, bez mogućnosti izlaza.

Noseći učinak zazornog i nepoznatog, gotička je simbolika i u službi prikaza neobične inverzije rodnih uloga: „Nanovo si pronašla utvaru, ideš s njome u krevet, zaljubiš se u nju: i sad pristaješ upoznati njezinu majku“ (p. 230). Spolna i rodna pomutnja, kako se roman bliži svome kraju, biva sve izraženija. Neobičnu i nesvakidašnju androginost glavne junakinje, kako onu fizičku i morfološku (p. 200), tako i onu duševnu i emotivnu (p. 263), autorica suprotstavlja „Zazornoj homoerotskoj enigmi““(Gatt-Rutter 1996, p. 57) dvaju muških likova, Richarda i Billa. Putem Billovog monologa u drugom licu jednine, kojim optužuje Giò za apsolutnu seksualnu nadmoć i tiraniju, autorica tekstualnim rascjepom inicira prikaz otvorene bitke spolova. U takvom se začaranom krugu nijedan od triju likova u potpunosti ne snalazi i sve ostaje do samoga kraja, na neki način, nedorečeno i nerazjašnjeno, nepoznato i zazorno.

\footnotetext{
186 1958. godine, Fallaci gubi dijete s muškarcem po imenu Alfredo. U tim se trenucima odaje alkoholu i sedativima. Naposlijetku doživljava živčani slom te biva hospitalizirana na psihijatrijskoj klinici. (De Stefano 2015, p. 79-81).

${ }^{187}$ Le Désir (Lacan 1992, p. 17).
} 
Naslov romana, Penelopa ratu, svakako je najznačajniji paratekstualni element koji ukazuje na inverziju rodnih uloga. U Odisejevoj odsutnosti, Penelopa doživljava gotovo potpunu metamorfozu, odnosno svojevrsnu duševnu i psihičku travestiju: „Činiš se Odisej, ali nisi Odisej, Penelopa si [ ... ] žena nije muškarac“ (p. 17). Na samome početku ove ljubavne melodrame Francesco upozorava prijateljicu na pogrešan stav koji zauzima, naspram rodnih uloga koje je društvo predvidjelo, tvrdi s razlogom, u svijetu. Nije na ženi da otkrije sva čuda i ljepote planeta, taj zadatak čeka muškarca, smatra on. No, Giò odbija poslušnost, podređenost i u konačnici povlačenje (p. 92-93). Odlučuje se za aktivno sudjelovanje u ratu koji obećava žrtve s obiju strana. Svjesna velikog uloga koji već na samome početku predaje oponentu, smatra da je u značajnoj prednosti u odnosu na Richarda, koji poput izgubljenog i nedozrelog Odiseja nikako ne pronalazi vlastito mjesto unutar ljubavnog trokuta, čijoj bezizlaznosti pridonosi lik autoritarnog i nametljivog „Oca“, Billa.

Fuziji autobiografskog i fikcije pridonose epistolarni trenuci koji povremeno prodiru u tekst, cijepajući roman u nekoliko razvojnih faza, između kojih naizmjence progovaraju čas likovi, čas pripovjedač, čas sama autorica. Preklapanje ekstradijegetskih i intradijagetskih razina pripovijedanja, nagli prelasci iz trećeg lica u drugo lice, te na kraju u prvo lice jednine, $\mathrm{u}$ konačnici rezultiraju snažnim otiskom govornog glasa. Svaka epistola nosi snažan autorski simbolički pečat, svaka je sastavljena u trenutku preokreta glavne radnje. Prvu epistolu sastavlja Giò po dolasku u novu, njoj nepoznatu, a ipak familijarnu zemlju. Adresat je kolega, nekad potencijalni ljubavnik, Francesco. Upravo onako kako je i sama Fallaci doživljavala Ameriku (De Stefano 2015, pp. 63-74; 101), opisan je njezin prvi dojam ove neobično različite i napredne zemlje kojom dominira kult Oca, kao glavnog izvora svih energija i snaga. Giò se u takvom magičnom okruženju golemih nebodera i masivnih betonskih blokova koji zure u nju osjeća veličanstveno:

\footnotetext{
Ovdje, nebo je na zemlji. Ovdje ljudi poput mene osjećaju da se rađaju po drugi put [ ... ] Ne postoji ništa, ne postoji nitko tko mi može nauditi. Osjećam se snažna, snažna, snažna, i ne nedostaje mi ništa osim tebe. (p. 29-30)
}

Nakon fantastičnog osjećaja ispunjenosti i naizgled dostižne apsolutne sreće, slijedi trenutak koji ostavlja autoreferencijalan otisak autoričnih bolnih emotivnih iskustava, u zemlji u kojoj je položila sve svoje nade (De Stefano 2015, p. 100-107). Nakon prvog seksualnog iskustva, s 
prikrivenim homoseksualcem, osobom koja je u potpunoj nemoći i nemogućnosti uzvratiti joj ljubav koju toliko traži, Giò prima njegovo pismo i tumači ga kao istinski zaljubljena žena:

Prvi letimičan pogled dao je naslutiti da je odbijena. Drugim, nešto opreznijim čitanjem, shvatila je napor koji je Richard uložio da bi sastavio takvo pismo. Treće minuciozno ispitivanje teksta otkrilo je ono što u naravi nije postojalo, ali ona bi voljela da jest. (p. 93)

Ne prihvaćajući poraz i povlačenje, Giò uzvraća novim pismom, u stilu samosvjesne, probuđene i oslobođene žene:

Ne trebaju meni liječnici. Nikada se nisam osjećala tako dobro. (p. 94)

Gotovo svaka riječ, interpunkcijska stanka i ritmička promjena govore autobiografskim jezikom. Ovdje Fallaci, s jasno određene autorske pozicije, promatra sebe očima žene: „Ona koja ovdje progovara jest Oriana, koja se probudila iz svoje opsesivne žudnje prema Alfredu“ (De Stefano 2015, p. 105). Prisjeća se trenutaka romanse i nevinog ushita, uzaludnih iščekivanja, umora i na kraju potpunog duševnog kolapsa nakon konačnog prihvaćanja činjenice da je sav emotivni kapital koji je uporno i marljivo investirala nepovratno izgubljen. Nakon niza neprekidnih odgađanja suočavanja s realnošću, junakinja se ipak odlučuje na napuštanje teritorija sukoba, šuteći o boli i ratnim povredama koje su je nepovratno izmijenile. Ovdje Fallacinu riječ preuzima muški lik Bill, visok i korpulentan muškarac istaknutih brkova, simbol nepogrešivog autoriteta i neuništive Amerike, zemlje ponosnih nebodera i mastodontskih tikvi (p. 100):

\footnotetext{
Ne štiti te nitko od trenutka u kojem se rađaš i plačeš jer si ugledala sunce. Sama si, sama, i kada si ozlijeđena uzaludno je da očekuješ pomoć jer ne postoji roditelj ili ljubavnik ili brat koji može gubiti vrijeme za te [ ... ] Pravi rat nije onaj koji vodiš onda kada dvoje budala odluči baciti bombu. Pravi rat onaj je koji vodiš u nenasilju ljubavi i mržnje [ ... ] Nemoj im govoriti da si se promijenila, nemoj im govoriti o ratu zbog kojeg si se promijenila. Zajednica u kojoj živiš ne zna što bi činila s martirima i herojima [ ... ] Moraš šutjeti ili lagati ne želiš li ih uplašiti. (p. 293-294)
}

Isprepletenost deskriptivnih, dijaloških i kompleksnih monoloških trenutaka, bujanje glasova i dinamika kojom se isti ističu u tekstu ostavljaju dojam prednosti govorene riječi, kojom se misao vraća tijelu, u odnosu na pisanu riječ, koju nitko ne izgovara. Svako direktno obraćanje 
i nagla promjena lica i lika koji govori u cilju je isticanja autoričinih osobnih iskustava i stavova.

O konceptu biseksualne prirode ljudskih bića, o razlikama koje ne poništavaju već umnožuju, o muževnosti unutar ženskog i ženstvenosti unutar muškog, o ,čudesnoj erotogenosti heterogenog“, ${ }^{188}$ progovara psihijatar i psihoanalitičar Igor:

Znaš li koji je najrašireniji kompleks u Americi? Za žene jest kompleks da su muškarci, za muškarce jest kompleks da su žene. Najčešće je to i jedan opravdani kompleks: nitko od nas nije u potpunosti muškarac ili u potpunosti žena. Naša nam civilizacija to onemogućuje. (p. 208)

Tekst koji „radi na razlici“, ${ }^{189}$ ne zatomljujući libidne porive koji upravljaju prostorom užitka, ${ }^{190}$ tekst kao analogija seksualnog čina, jer njime biva artikulirana žudnja, ${ }^{191}$ tekst je kakvim upravlja Oriana Fallaci. Fallacina retorika, obilježena apsolutnom slobodom izgovorene riječi, briše formalne jezične zakone i rigidnu sintaksu, fizički materijalizirajući ono o čemu sama autorica razmišlja. U romanu ostaje prilično nejasan prijelaz pisanog $\mathrm{i}$ izgovorenog. Pisanje kao da je u funkciji svojevrsne katarze i rehabilitacije izgovorenog, a govorni je čin, s druge strane, opomena i podsjetnik da taj kozmički prostor tekstualnog nastaje u najdubljim i najnedostupnijim slojevima ženske psihe, te potječe uvijek i izravno iz glasa. Granica glasa glavne junakinje, pripovjedača i autorice, kako se roman bliži svome kraju, biva sve nejasnije izražena i na posljednjim se stranicama teksta, prelazeći iz pripovijedanja u trećem i drugom licu u prvo lice jednine, gotovo stapa $u$ jedan jedinstven glas:

Potom ću se obračunati s onim maloumnicima koji me kritiziraju jer sam žena. Bolja sam od muškaraca i Penelope ne koriste ničemu. Ja vodim rat i zakon muškaraca: ili ja ili ti. Ili ja ili ti. Ili ja. (p. 306)

\footnotetext{
${ }^{188}$ Cixous, H. (1975b, p. 260).

${ }^{189}$ Cixous, H. (1977a, p. 480).

190 Jouissance (Lacan, 2017).

${ }^{191}$ Moi, T. (2007, p. 176).
} 
Za žensko je pismo od izuzetne važnosti da autorica uspješno nadvlada simbolički poredak i ovlada njegovim jezikom, kako bi vlastiti glas vratila tijelu iz kojeg je isti izniknuo. Posljednji zvuci Fallacinog glasa u tekstu svjedoče o ženskom pisanju kao vraćanju stvarnome tijelu, te ženskom autorskom glasu kao konačnoj inkarnaciji žudnje u jeziku (p. 306-18). Fallacina biseksualno tekstualna kreativnost, osobito u romanu Penelopa ratu, u apsolutnoj je uskoj i vrlo intimnoj vezi s autoričinim svjesnim, podsvjesnim, ali i nesvjesnim glasom. 


\section{II. III. Placentalna retorika}

Virginija Woolf i Simone de Beauvoir isticale su kako žensko pismo, odnosno općenito umjetničko stvaralaštvo, proizlazi iz specifične ženske perspektive, koja je, s druge strane, uvjetovana prvenstveno ženskim iskustvima, kao i položajem žena unutar društva te njihovim kroz povijest limitiranim obrazovanjem. Takav pogled na žensku umjetničku produkciju podrazumijeva neesencijalistički pristup rodne i spolne problematike, vezane uz kontekst jezika i kulturne proizvodnje, odnosno promatranje rodnoga, pa i spolnoga, identiteta kao cjeline u neprekidnom procesu nadogradnje.

Na suprotnoj, iako ne u potpunosti, strani ovakvog (de)konstruktivističkog modela spolnog i rodnog unutar jezičnog, stoji tzv. esencijalistički pristup, unutar kojeg se ženska bit, ženski pogled i razumijevanje okoline, kao i ženska umjetnička produkcija, dovode u najužu moguću vezu sa ženskom biologijom i morfologijom.

Ova dva, naoko duboko rascijepljena teorijska modela u jednome se području ipak, ponekad djelomično, češće gotovo i potpuno, preklapaju - u prostoru ženske poetike i estetike kao zasebnog umjetničkog stila.

U zbirci teorijskih rasprava naslovljenih $U$ ženskom ključu, pozivajući se na teorijske formulacije Ilme Rakusa, Čačinovič navodi neke od najrelevantnijih značajki ženske estetike, poput izražene subjektivnosti $i$ asocijativnosti, polifonog $i$ fragmentiranog sebstva pripovjedača, ukidanja linearnih naracija destrukcijom vremensko-prostornih koordinata, procesualnosti, polilogike i sinkretizma žanrova, kao i posebne sklonosti dijalogijskim i polifonim vrstama teksta. Također, kako Čačinovič navodi, radi često pristutne ženske jezične skepse, odnosno radi svijesti o razlici između stvarnoga života i napisanoga te hiperosjetljivosti za jezične formule, ženska je estetika često usmjerena na usmeno izražavanje, na ritam svakodnevnog govornog jezika, označenog snažnim i jasnim interpunkcijskim stankama, mnoštvom usklika i pitanja. Neobična ženska sintaksa, dodaje Čačinovič, eliptična je i parataktična, usmjerena na zaokruživanje, a sklonost motivima poput tijela, tjelesnih tekućina i općenito vodenog medija, u ženskoj je umjetničkoj produkciji, zaključuje autorica, izuzetno izražena (Čačinovič 2000, p. 57).

Promatranje ženskosti kao zasebnog umjetničkog stila, uvažavanje posebnog odnosa ženskoga tijela i ženskoga teksta, te pokretanje ozbiljnih teorijskih rasprava o ženskoj jezičnoj strategiji, započinje unutar kontrakulturnih pokreta 60-ih godina, u sklopu raznih 
neofeminističkih struja, te nanovo sredinom 70-ih, kada je općenito dominantan trend $\mathrm{u}$ tumačenju ženske umjetničke produkcije postao ginocentrični istraživački pristup, što u konačnici stvara i uvjete za novu vrstu ženskog pisma.

Upravo ta razdoblja obilježena su, kako u Europi, tako i u SAD-u, naglim društvenim promjenama. U samo središte pozornosti novih feminističkih gibanja dolaze teme poput rodne i spolne nejednakosti, ženske seksualnosti i majčinstva, te nužnosti potpune lingvističke dekonstrukcije svih instalacija simboličkog poretka. Ženski tekstovi koji izlaze sredinom 70ih u velikoj su mjeri natopljeni osobnim iskustvima, a karakterizira ih nekonvencionalna, antitradicionalistička, „taktilna retorika“ (Irigaray 1977, p. 76). U takvom trenutku ideoloških i simboličkih društvenih promjena, izlazi Fallacin roman Pismo nerođenu djetetu, ${ }^{192}$ autoričino ujedno najprodavanije, najčitanije i najprevođenije literarno djelo.

$\mathrm{Na}$ tankoj granici stvarne ispovijesti i svijeta fikcije autorica postavlja neka od temeljnih egzistencijalističkih dvojbi, o smislu života i rađanju, o definiciji života i živog ljudskog bića, o ženinom pravu na tijelo. 70-ih je godina u Italiji pitanje pobačaja, odnosno majčinstva i ženske seksualnosti, podijelilo javnost, uzrokovalo pad vlade i raspisivanje državnog referenduma. U tako uzavreloj i politički nepovoljnoj klimi Fallaci zauzima vlastiti stav te kreće u autobiografski literarni projekt, koji će žestokom brzinom izazvati burne reakcije javnosti. De Stefano (2015, p. 211) ističe kako je izlazak ovog romana istodobno zgrozio progresivne, jer je očito da prema mišljenju autorice život počinje začećem, ali i konzervativce, jer je ipak, tvrdi Fallaci, žena jedina ta koja ima apsolutno pravo i slobodu odlučivanja o vlastitoj trudnoći i njezinom konačnom ishodu. Aricò (1998, p. 163) tvrdi kako su upravo ta ambivalentna pozicija i ,istodobno flertovanje s liberalima i konzervativcima“ zaslužne za planetaran uspjeh romana. Iako se kroz čitav period svoje karijere Fallaci konkretno distancirala od radikalnog političkog feminizma, više puta istaknula kako Pismo nerođenu djetetu nije roman o pitanju i pravu na pobačaj, već „roman o sumnji i boli“ (De Stefano 2015 , p. 221), feminističke će polemike istodobno potaknuti prodaju knjige, ali i otežati razumijevanje njezinog sadržaja.

Prve skice romana nastaju 1966. godine, nakon autoričinog drugog iskustva spontanog pobačaja, kada vlastitu bol i osjećaj praznine odlučuje pretočiti u tekst. Ipak, još uvijek nespremna i nedovoljno emotivno osnažena, skice odlučuje vratiti u ladicu, gdje ostaju

\footnotetext{
192 Lettera a un bambino mai nato, 1975 a.
} 
sljedećih devet godina. 1974. godine, na poziv i prijedlog Tommasa Giglia iz Europea da napiše članak o tada vrućoj temi u društvu, skice odlučuje izvući na svjetlo dana, te, filtrirajući ono što je smatrala preosobnim ili odviše emotivnim, oblikuje njihov sadržaj u „poetski roman-esej“ (Gatt-Rutter 1996, p. 80), na granici lirike i proze, autobiografskog i fikcije: „Od tadašnjeg krika ostaje malo: početak, kraj, epizoda o Mjesecu koji mi se lomi među rukama. I ako sam u jučerašnjem kriku glavna junakinja bila ja, u današnjem shvaćanju ta junakinja nisam više ja. Možda žena koja mi nalikuje“ (De Stefano 2015, p. 219).

Fallaci je više puta istaknula kako su joj vlastita iskustva pripomogla da na izuzetno intiman, neposredan i dirljiv način opiše razgovor majke s djetetom u utrobi (Aricò 1998, p. 164). Ipak, kako i većina kritičara danas svjedoči, autorica istodobno odlučno inzistira i na nužnom pristojnom odmaku teksta od njegovog autora, odnosno inzistira na činjenici da tekst, baš kao i nerođeno dijete, od trenutka začeća, pa sve do konačnog poroda, ima vlastiti kreativni put, neovisan od Boga, majke ili autora, pa čak i društva, odnosno čitateljske publike. Prema autoričinom je mišljenju tekst neovisan konačan produkt sklopa raznih i raznovrsnih životnih okolnosti i iskustava koji vlastito mjesto pronalazi na potpuno spontan $\mathrm{i}$ nadasve nepredvidiv način (Aricò 1998, p. 171-173).

Vezu autobiografskog i fiktivnog teško je, no ipak moguće, razgraničiti, a otežavajućih je okolnosti nekoliko. Aricò (1998, p. 167) kao glavni dokaz čvrste i neraskidive veze autora $\mathrm{i}$ pripovjedača ističe samu temu romana - sumnju. Egzistencijalistička sumnja, koja kola čitavim romanom, centar je i Fallacinih razmišljanja. Prolazeći više puta kroz iskustva spontanog pobačaja, svjedočeći kao dijete strahotama Drugog svjetskog rata, radeći kao izvjestitelj u ratom zahvaćenim područjima gdje su glad i bolest ljudska svakodnevica, ali i prateći kao novinar bitku za prvi odlazak na Mjesec, Fallaci se kroz čitavu svoju karijeru neprestance preispitivala o tome što život jest, koji je njegov istinski smisao, kada i gdje on počinje, a kada i gdje završava.

Roman obiluje autobiografskim podacima, odnosno cjelokupna su tematika i kontekst u koji je ista uronjena odraz autoričinih osobnih iskustava. Upravo kao i Fallaci, i majka u tekstu samostalna je i neovisna poslovna žena, koja radi kao spisateljica za poznatu izdavačku kuću i strahuje da će trudnoća ozbiljno ugroziti njezin poslovni napredak. I majka i Fallaci neodlučne su po pitanju smisla i kvalitete ljudskoga života na zemlji, no istodobno jasno 
određene kada su predmet rasprave etičke i ideološke dvojbe vezane uz temu pobačaja i definicije živog ljudskog bića.

U romanu se pojavljuju i autoreferencijalni elementi u obliku četiri bajke koje majka, kao pripovjedač, zamišlja, a potom izgovara na glas. Četiri istodobno sintaktički odvojena, no semantički povezana subteksta, stvarajući strukturalni mise en abîme efekt, proizvode $\mathrm{u}$ konačnici ulančani niz nekonvencionalnih osobnih ispovijesti, prerušenih u žanr bajke. ${ }^{193}$ Sva četiri teksta, u psihoanalitičkim terminima, predstavljaju se kao simbol nezadovoljene Žudnje $e^{194}$ (Lacan 1992, p. 17), odnosno označavaju prededipsko imaginarno, simbiotsko razdoblje koje zrcalnim mise en abîme označiteljskim rezom omogućuje pripovjedaču ovladavanje simboličkim poretkom i njegovim jezičnim zakonima, ${ }^{195} \mathrm{u}$ svrhu nadilaženja osjećaja žudnje i pronalaženja Realnog, odnosno „u svrhu uspješne kontrole vlastitog teksta i jezika“(Cixous 1977b, p. 18).

Ipak, roman sadrži i elemente fikcije, koje autorica najčešće, u nemogućnosti da djelo prikaže kao jasno autobiografsko, veže uz fantastične i oniričke trenutke, poput snova i noćnih mora koje majka u trudnoći proživljava, razgovora $\mathrm{s}$ djetetom u utrobi, te $\mathrm{u}$ konačnici nerazriješenih moralnih nedoumica prikazanih u obliku suđenja koje kulminira obraćanjem nikad rođenog djeteta. Djelo se tako predstavlja kao autobiografski camouflage, odnosno kao dnevnik preobražen u roman s elementima autobiografskog.

\footnotetext{
${ }^{193}$ Nekonvencionalni žanr u odnosu na roman.

194 Žena koja uspijeva dotaknuti cvijet magnolije (čije pupanje, puni cvat i opadanje na tlo simboliziraju ujedno proces Fallacinog emotivnog sazrijevanja), podmećući vlastiti život (Fallaci 1975a, p. 38-41), neispunjena žudnja za luksuznim gianduiotti slatkišima i arogancija bogatih koji se u njoj kupaju (p. 41-45), nedostižnost pravde i slobode oslikana u vremenu pokreta otpora i oslobođenja od nacifašističkog režima (gdje glas pripovjedača upućuje na egzaktne događaje iz autoričinog djetinjstva, poput dolaska crnokošuljaša, smaknuća protivnika režima, bombardiranje Firenze od strane Saveznika te hapšenje i zlostavljanje Edoarda Fallacija, Orianinog oca), kada se vjera i nada u bolje sutra pretvaraju u duboku skepsu i razočaranje (p. 45-50), te ispovijest mlade žene, nastanjene u modernom, kapitalističkom i konzumerističkom društvu izobilja (riječ je o samoj Fallaci u ranim tridesetima, na samome vrhuncu novinarske karijere u SAD, kada je od 1963. do 1965., boraveći u N.A.S.A. centru na Floridi, pratila pripreme i odlazak astronauta na Mjesec) u kojem je čovjek uspio postići gotovo sve i jedino što mu preostaje jest da dodirne drugi planet. Usprkos svim obećanjima (spominje se astronaut Apola 12, Pete Conrad, kojem autorica posvećuje više redaka u autobiografskom romanu Se il sole muore 1965., te 1969. članak pod naslovom Conrad u Europeu) da će dobiti na poklon komadić Mjeseca, njegova se prašina pod mlazom vode otopila i nestala, poput Conradovog i Fallacinog prijateljstva, prekinutog radi različitih političkih pozicija glede Nixonovih odluka o američkoj intervenciji u Vijetnamu (p. 70-74).

195 U odnosu na ostatak teksta, ova četiri narativno odvojena hipodijegetička teksta, okrenuta su klasičnom pripovijedanju u trećem licu i prošlom glagolskom vremenu.
} 
Način i tijek uplitanja autobiografskog, odnosno fiktivnog, ukazuju na strategiju i dinamiku kojom je krojen tekst. Naime, početak romana, u kojem se opisuje majčino stanje i cjelokupan kontekst koji prati njezinu rizičnu trudnoću, ostavlja snažan autobiografski pečat. No, kako se razgovor majke s djetetom sve više razvija i polako bliži svome kraju, elementi fikcije sve više dominiraju i preuzimaju veći tekstualan prostor. Deskriptivnih je trenutaka sve manje, dok je dijaloške i monološke dinamike sve više. Glasovi i šumovi u tekstu bivaju sve brojniji, sve je jače izražena njihova konfliktna, te naposljetku i katarktična uloga, a kulminacija te izražene fantastične vokalne polifonije zamišljena je u obliku suđenja, ${ }^{196}$ kojim se, na određen način, uspostavlja lingvistička granica stvarnog i nestvarnog, tjelesnog i psihološkog, teksta i konteksta. Buđenje u sobi s bijelim stropom koji lebdi iznad majčine glave, pogled na čašu u kojoj pluta njezino nerođeno dijete i sedam članova porote koji joj sude (Fallaci 1975a, p. 76101) elementi su fikcije koji dominiraju posljednjim stranicama teksta i kojima se autorica jasno i javno ogradila i distancirala od ostatka teksta, odnosno od boli o kojoj on svjedoči.

Pismo nerođenu djetetu roman je krojen po principu bricolagea: elementi autobiografskog i fikcije nadopunjuju se i prepliću, stvarajući potpuno nov i jedinstven literaran entitet. Evidentno je, i više puta od strane same autorice potvrđeno, da je kao imaginativni predložak za ovo protukonzervativno i postmodernistički orijentirano djelo poslužilo njezino vlastito iskustvo. Međutim, ovdje se ne radi o klasičnim autobiografskim postupcima i tehnikama. Naprotiv, ovdje je riječ o odlučnom odmaku od istih. Naime, tadašnja američka postmodernistička kulturna scena, u koju je i sama Fallaci već od konca 60-ih duboko uronjena i unutar koje je literarno djelovala, donosi novitete na području autobiografije. ${ }^{197}$ Nove lingvističke i narativne tehnike, koje nastaju pod snažnim utjecajem poststrukturalističke i postmodernističke teorije, omogućile su da dotad zanemarena ženska autobiografija pronađe vlastito mjesto unutar kanona. Osnovna je karakteristika ovih novih, tehnički i sadržajno osvježenih autobiografija nepostojanje univerzalnog i jedinstvenog sveznajućeg sebstva izvan lingvističkih granica teksta, odnosno nepostojanje unaprijed izgrađenog autorskog identiteta koji se naknadno u vlastitoj autonaraciji samopotvrđuje i prema kojoj se odnosi nadređeno i superiorno (Cavarero 1997, p. 89-102).

\footnotetext{
${ }^{196}$ Klimaks romana.

${ }^{197}$ Pod osobitim utjecajem neoavangarde i neoeksperimentalizma 60-ih.
} 
To nepostojanje jasno određene granice autorovog $\mathrm{Ja}$ i teksta subjekta u nastanku temeljna je karakteristika Fallacinog romana. U jednom razgovoru sa Santom L. Aricòm 1991. (Aricò 1998, p.171-172), Fallaci objašnjava vlastite stvaralačke strategije te viziju i mišljenja oko odnosa autora i teksta u nastanku. Naime, ono što je tih godina perzistiralo kao uobičajena praksa uoči početka komponiranja romana jest sastavljanje sinopsisa, u talijanskoj tradiciji poznatijeg pod nazivom la scaletta, te je nakon toga, u dogovoru s urednicima, započinjalo pisanje. Fallaci se, međutim, takvoj uvriježenoj praksi žestoko protivila, ističući kako je scaletta ozbiljna prepreka kreativnom procesu: „Ako prethodno sastaviš scalettu, već si tako reć' napisao knjigu!“ (p. 171). Odbijajući komponiranje bilo kakvih preliminarnih sažetaka i jasno određenih projekata, odbacujući mogućnosti i prakse unaprijed skiciranih poglavlja, Fallaci jasno izražava i označava primat teksta u odnosu na autora. Prema njezinom mišljenju (p. 172), tekst spontano stvara vlastitu povijest i nudi dobrodošlicu autoru kao aktivnom sudioniku. Upravo onako kako poststrukturalističke teorije i najavljuju, tekst je taj koji donosi stabilnost i kompaktnost autorovog $J a$, tekst stvara sljedećeg koji progovara, te su, u tom smislu, autor i pripovjedač čisti rezultat retoričkih tekstualnih strategija, a to Fallaci potvrđuje oniričkim elementima, poput scene suđenja i obraćanja djeteta majci, trenutak u kojem je, ističe, kreativna energija krenula u posve novom, nepredviđenom, pravcu (p. 172).

Upravo kako je i Adriana Cavarero (1997) istaknula, kada je govorila o karakteristikama ženskih i ženstvenih autobiografija, i Pismo nerođenu djetetu nastaje kao multifragmentiran slijed životnih segmenata, koji vlastiti značaj traže upravo u tekstu, a Fallacina životna iskustva i događaji svoj oblik i značaj u potpunosti ostvaruju tek unutar granica tekstualnog, odnosno, semiotičkim riječnikom, unutar interpretativnih granica čitatelja. Oslanjajući se na vlastitu intuiciju, dugoročno pamćenje te imaginativni talent koji je u velikoj mjeri posjedovala, Fallaci odustaje od tradicionalnog pristupa autobiografskom pismu, kao i općenito od dotadašnjih žanrovskih ograničenja i uzusa, te odlučuje isključivo slijediti vlastiti sustav razmišljanja, oslobođen od falogokratičnih zapadnjačkih dogmi i kulturno-političkih prepreka.

Cristina De Stefano (2015, p. 211) ističe kako je za velik uspjeh ovog romana prvenstveno zaslužan narativni okvir za koji se Fallaci odlučuje. Taj neposredan dijalog majke s djetetom u utrobi, monolog usamljene mlade poslovne žene kojoj nitko ne zna ime, omogućio je mnogim čitateljicama da se upravo u toj ulozi identificiraju. Također, zanimljivo je istaknuti da, osim majke i djeteta, ni drugi likovi prisutni u romanu ne posjeduju ime, kao ni podrobniju fizičku i 
psihološku karakterizaciju. John Gatt-Rutter (1996, p. 80) smatra da je glavni razlog tome činjenica da su likovi, odnosno glasovi koji odjekuju, glasovi koje majka, kao pripovjedač, osluškuje unutar sebe, ali i u metaforički prenesenom ključu, oni su primarno zvuci konfliktnog višeglasja koje perzistira u suvremenom društvu, a najvećim se dijelom odnose na konkretan konflikt dvaju spolova.

I dok je, s lingvističkog aspekta, kod navedenih likova došlo do gotovo potpune depersonalizacije i neutralizacije osobnosti, lik nerođenog djeteta u utrobi Fallaci nastoji učiniti što je više moguće prisutnim i stvarnim. Putem niza manjih konzekutivnih fotoreportaža, fotodokumenata majčinih uzastopnih ultrazvučnih pretraga, dijete polako poprima svoj vizualni identitet i karakteristike osobnosti. Ta vizualna strategija personalizacije djeteta za konačni cilj ima „označavanje fetusa kao osobe i donošenje majčine odluke da ga zadrži“" (Gatt-Rutter 1996, p. 83). Karakterizacija, odnosno odbijanje klasične karakterizacije likova ima dublje, konkretnije, tekstualne razloge. Supresija bilo kakve vrste imenovanja likova, događaja ili mjesta, leksička i sintaktička jednostavnost kojom isti bivaju spomenuti, kao i uporno ustrajanje na retorici slobodnog govornog čina, idu u prilog antikonzervativističkoj tezi o nestabilnosti i nesamostalnosti autorskog subjekta izvan granica teksta, odnosno o konceptu pripovjedača i lika kao promjenjivim kategorijama, čija sudbina ovisi uvijek i isključivo o semiotičkim mogućnostima teksta.

Narativni aspekt romana predstavlja se kao izuzetno slojevit i neuobičajen, a čitavo je vrijeme vođen dramatičnim monologom majke koja, u pripovjedačkoj ulozi, obraćajući se u prvome licu, odnosno djetetu u drugome licu jednine, putem stilski izuzetno izraženog govornog čina, kroji naposljetku vlastitu ulogu i mjesto koje ona kao lik u romanu zauzima. Ta primarna narativna istanca, koja ujedno podržava temeljni okvir za autorsku eksploataciju osobne povijesti, političkih stajališta i egzistencijalističkih dvojbi, gotovo je cijelo trajanje romana popraćena uporabom prezent perfekta, ${ }^{198}$ glagolskog vremena koje briše granice sadašnjosti i prošlosti, donoseći osjećaj kontinuiteta i kauzalne povezanosti događaja i likova međusobno udaljenih na horizontalnoj kronološkoj osi. ${ }^{199}$ Iako s lingvističkog aspekta izrazito jasna i tehnički precizna, s onog naratološkog Fallaci kao da je u potpunosti i vrlo odlučno

\footnotetext{
${ }^{198} \mathrm{U}$ talijanskoj se gramatici prevodi kao passato prossimo.

${ }^{199} \mathrm{~S}$ iznimkom u slučaju majčinog pripovijedanja bajki, gdje se tekst s pripovjedačem u prvom licu jednine prelijeva u četiri fragmentirana hipodijegetička teksta $s$ pripovjedačem u trećem licu jednine i radnjom u imperfektu, narativna strategija koja jasno određuje intenciju autorice da vremenski i prostorno ograniči i onemogući utjecaj prošlosti na budućnost teksta.
} 
„antiliterarna“ (Gatt-Rutter 1996, p. 170). Inzistira na izvorno književnoj i gramatički neutralnoj sintaksi, bez ikakvih fleksija ili lingvističkih redukcija koje karakteriziraju njezin firentinski govor, kao i na jednostavnom i jasnom leksičkom odabiru kojim, velikom brzinom i lakoćom, dopire do svih slojeva čitateljske publike. Istodobno, međutim, odabirući prezent perfekt kao glagolsko vrijeme koje će dominirati tekstom te neposrednog pripovjedača koji se obraća u prvom i drugom licu jednine, odskače od rigidnih i tradicionalnih književnih konvencija, te se okreće jednom posve osobnom i neuobičajenom pripovjednom modusu. Naime u Le Degré zéro de l'écriture ${ }^{200}$ (Nulti stupanj pisma), Roland Barthes predstavio je ključne elemente tradicionalnog romana, među kojima su upravo pripovijedanje u trećem licu te obraćanje u prošlom glagolskom vremenu, najčešće preteritu, kao uzvišenom obliku prošlog vremena prisutnog isključivo u pisanom književnom jeziku (1984, p. 30), a čini se da upravo od takvih tradicionalističkih vrijednosti odustaje Oriana Fallaci. Obzirom da su zapadni kanon i sama institucija književnosti iznikli iz lingvistički obilježenog muškog područja i polja razuma, autorica im jasno i nedvosmisleno okreće leđa, što naposljetku i eksplicitno u samome romanu pripovjedač i navodi: „Znam: naš su svijet stvorili muškarci, za muškarce, njihova je diktatura tako stara da se proteže čak i na jezik“ (Fallaci 1975a, p. 12). Jasno iskazujući nezadovoljstvo i revolt protiv jednostrano orijentiranih jezičnih zakona, protiveći se patrijarhalnoj teogoniji koja Boga Oca, njegovog Sina i Duha Svetoga prikazuje u muškom licu (p. 12-13), te ukazujući na sveprisutan seksizam u talijanskoj gramatici, kojom se spolna i rodna nejednakost potiču i produbljuju ${ }^{201}$ (p. 14-15), majka u romanu ozbiljno razmatra goruće znanstvene teme svoga stoljeća, teme kojima su se brojni lingvisti i feministice bavili, a nakon izlaska ovoga romana i često dovodili u vezu sa samom autoricom. ${ }^{202}$

Narativna avangardnost Fallacinog romana evidentna je i na razini adresata, ove neobične epistolarne poetsko-prozne forme. Naime, obraćanje majke djetetu, kao i djeteta majci, može biti protumačeno i kao obraćanje autora tekstu, odnosno kao tekst koji, kao konačni produkt

\footnotetext{
${ }^{200}$ Barthes, R. (1953), Le Degré zéro de l'écriture, Paris: Seuil. Korišten prijevod: Writing Degree Zero and Elements of Semiology, (1984), London: Jonathan Cape.

201 Poput talijanske riječi uomo (čovjek), kojom se istodobno isključuje riječ donna (žena), ali i uključuje u široko semantičko polje, koje kao da pokriva sva tri roda, toliko posebnu i različitu ženu.

${ }^{202}$ Lepschy, G. (1991), Language and Sexism, u: Baránski i Vinall, p. 117.
} 
pripovijedanja, progovara i odlučuje o vlastitoj sudbini. John Gatt-Rutter (1996, p. 63) govori o tzv. placentalnoj retorici ${ }^{203}$, koja se razvija putem pupčane vrpce:

\begin{abstract}
Ti i ja smo zaista čudan par. Sve u tebi ovisi o meni i sve u meni ovisi o tebi: ako se ti razboliš i ja se razbolim, ako ja umrem, umireš i ti [...] Nikad dva stranca, vezana istom sudbinom, nisu bila nepoznatija jedno drugome. Nikad dva neznanca, ujedinjena $\mathrm{u}$ istom tijelu, nisu bila tuđa jedno drugome, udaljenija nego što smo nas dvoje [...] Jedino što nas spaja, drago moje, to je pupčana vrpca. I nas dvoje nismo par, već progonitelj i progonjeni. Ti si na mjestu progonitelja, a ja na mjestu progonjenoga. Uvuklo si se u me poput lopova i otelo mi utrobu, krv, dah. Sad bi mi htjelo oteti i cijeli život. Neću ti to dopustiti. (pp. 26; 62)
\end{abstract}

Ovdje je riječ o izuzetno intimnoj konverzaciji s izraženim foničkim aplitudama koje ovaj put ne putuju zračnim vibracijama, kako je to u svakodnevnoj komunikaciji uobičajeno, već putuju biološkim tkivima i tjelesnim tekućinama. Obraćanje pripovjedača u drugom licu

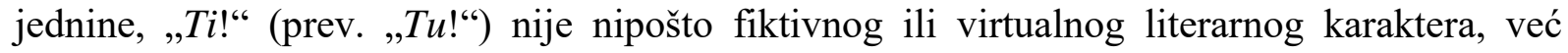
naprotiv, u terminima Derridaove dekonstrukcijske filozofije, riječ je o metafizičkoj prisutnosti riječi koju dotičan subjekt izgovara (Derrida 2007, p. 299), a ta prisutnost vezana je uz žensku tjelesnu dimenziju i govori o vrlo intimnoj povezanosti jezika s osjetom dodira. U sigurnosti majčine utrobe, u beskonačnom i imaginarnom vodenom prostoru heterogenog (Cixous 1975, p. 260), u prededipskom prostoru koji ujedno zaštićuje i spaja, dijete progovara:

\begin{abstract}
Zajedno s vodom koja me oplakivala, pio sam svaku tvoju misao. I svaka tvoja misao imala je okus otkrića. Moje je tijelo bilo samo projekt koji se razvijao u tebi, zahvaljujući tebi; moja misao bila je samo obećanje koje se ostvarivalo u tebi, zahvaljujući tebi [ ... ] moji srkovi svjetlosti bila si ti. (Fallaci 1975a, p. 89)
\end{abstract}

\footnotetext{
${ }^{203}$ Placentalni odnos majke i djeteta, intrauterina zbivanja tijekom trudnoće, autorica kao da je prenijela u prostor tekstualnog. Naime, placenta predstavlja tkivo koje je stvorio embrij, te koje, premda priljubljeno uz sluzokožu maternice od nje ostaje odvojeno. Iako stvorena od embrija, placenta se ponaša kao zaseban organ, gotovo neovisan o embriju. Ona je komunikacijsko-regulacijski kanal putem kojeg se događa razmjena između dvaju organizama, majke i djeteta, a da pritom nikad ne dođe do fuzije majčinih i embrionalnih tkiva. Zadatak placente je da sprema, transformira i preusmjerava majčine hranjive tvari za vlastite potrebe, kao i za potrebe rasta fetusa, pritom ne iscrpljujući majku i ne pretvarajući je u razvodnik hranjivih tvari. Također, ovaj organ, iako anatomski ovisan o embriju, izlučuje majčine hormone, prijeko potrebne za trudnoću, kada su funkcije nekih važnih endokrinih žlijezda reducirane. Upravo ova samostalnost i regulatorska sposobnost placente omogućuje rast jednog tijela u drugome, bez mehanizma potpunog spajanja (miješanja krvi majke i fetusa), kao i mogućeg odbacivanja djelomično stranog tijela u organizmu majke (obzirom da polovica embrionalnih antigena potječe od oca). Placenta je prostor dugih i kompleksnih razgovora i pregovora, prostor prihvaćanja i tolerancije, uvažavanja različitosti i različitih potreba (Irigaray 1990, p. 31).
} 
O karakteristično ženskoj dubokoj i vrlo intimnoj povezanosti s vlastitim tijelom i tijelima u svojoj blizini, u ovom slučaju nutrini, te o osnovnim svojstvima te specifično ženske prirodne i arhaične veze, pisala je Luce Irigaray. ${ }^{204}$ Ženstvenost, neposredna i prirodna povezanost $\mathrm{s}$ vlastitom ženskošću, prema Irigaray, tekućeg je svojstva, a ženstven je jezik onaj jezik koji se upravo poput fluida opire svakoj fiksaciji i konačnom označivanju. Izjavom kako ,ženinu fizičku stvarnost određuje trenje između dviju beskrajno susjednih sila - dinamika blizine, ne vlasništva“ (1977, p. 109-110), podsjećajujući time na Barthesove teze o tekstualnoj nadmoći i nemogućnosti autora da njime u potpunosti vlada i manipulira, Irigaray opisuje le parler femme (womanspeak/ženski govor). Ženski je govor pluralan, inkluzivan te odbija bilo kakvu vrstu posjedovanja, odnosno vlasništva, o čemu, u tekstu, svjedoči i sama Oriana Fallaci: „Ti ne pripadaš ni Bogu, ni Državi, ni meni. Pripadaš samo sebi i gotovo“ (Fallaci 1975a, p. 30).

I prema Hélène Cixous ženska je tekstualnost bespuće koje karakterizira razmjena s onim Drugim (Autre), a ta se razmjena, objašnjava Cixous, događa putem tekućeg medija, najženstvenijeg među ženstvenim elementima, $u$ kojem sve neprestance teče i prelijeva se $u$ jedno: „Jezik tisuću jezika [ ... ] jezik koji dopušta da drugi jezik govori“ (1975c, p. 162).

Upravo je ta komunikacija putem tjelesnih tekućina znakovita i u romanu Oriane Fallaci. Glas majke, kao i glas djeteta, jer „kada žena progovara kazuje i o onom drugom unutar sebe“ (Irigaray 1977, p. 28), odjekuje u prostoru heterogenog fluida, prostoru koji sve binarne opreke, krute i nasilne jezične zakone, u potpunosti poništava. Taj kozmički vodeni prostor vječnosti, obilježen apsolutnom slobodom i odsustvom autoriteta, ispunjen je glasom, govornim činom. „Ti!“ koje odjekuje tkivima majčine utrobe retorički je trop kojim majka fizički materijalizira, tjelesno označava, sav onaj mentalni sadržaj koji izvire iz najdubljih slojeva njezine psihe (Cixous 1975b, p. 251; 1975c, p. 170). Apostrofiranjem, ${ }^{205}$ retoričkom tehnikom kojom je ambivalentan status ploda koji pluta u amniotičkoj tekućini dodatno doveden u pitanje, Fallaci manipulira tekstualnu strukturu, odnosno sljubljuje fikciju i stvarnost, pisanje i govorni čin.

Kako je govor, odnosno glas, koji u Fallacinom romanu povezuje fizičko i metafizičko, ključan strukturalni element djela, nužno je istaknuti njegove osobite značajke.

\footnotetext{
${ }^{204}$ Irigaray, L. (1977).

205 Apostrofa je oblik ventrilokvizma putem kojeg pripovjedač daruje glas, život i ljudske značajke adresatu, mijenjajući njegovu tišinu u prikrivene, ali znakovite odgovore (Johnson, B. (1986), »Apostrophe, animation and abortion«, Diacritics, 16.1: p. 29-39, u: Warhol and Herndl, (1991), p. 630).
} 
Na sintagmatskoj razini, izuzetno izraženoj foničnoj dimenziji djela, odnosno akustičnom efektu pisanog jezika, pridonose kvalitativna i kvantitativna distribucija sintaktičkih granica te prozodemskih elemenata. Iako autorica roman odlučuje objaviti u proznom obliku, ritmička versifikacija, koja dominira tekstom, nipošto nije izgubljena, a najistaknutija je upravo u onim dijelovima romana u kojima je obraćanje majke djetetu najposrednije, u kojima su sintaktičke granice svedene na minimum, a deskripcije gotovo da i nema:

Stanotte ho saputo che c'eri:

una goccia di vita scappata dal nulla.

Me ne stavo con gli occhi spalancati nel buio,

e d'un tratto, in quel buio,

s'è acceso un lampo di certezza:

Sì, c'eri.

Esistevi.

(Fallaci 1975a, p. 7)

[Noćas sam saznala da jesi, da postojiš: kap života izbjegla ni iz čega. Stajala sam razrogačenih očiju u mraku i odjednom se u tom mraku upalio bljesak sigurnosti: da, postojiš. ]

U lirskom duhu firentinske literarne tradicije, Fallaci ne odolijeva klasičnom metru i zvučnosti koju njegova kvantitativna i akcenatska izmjena proizvode. Naime, transkript talijanskog originala ukazuje na alternaciju anapesta i jamba, metričkih stopa karakterističnih za pjevne, na glas izgovorene, stihove. Prva četiri stiha, koja se pojavljuju u obliku anapesta, označavaju trenutak sumnje i suspenzije, stoga je prikladno tome i akcenatska stopa dulja. Sumnju i nesigurnost naglo prekida snažan jamb, koji foničnost i ritmički impuls izgovorenih jedinica dovodi do svog izražajnog maksimuma, označavajući pritom trenutak egzistencijalne istine: „Da, postojišs!“.

Vrlo vješto postignutu foničnost romana, na paradigmatskoj razini dodatno potiču ilokucijski retorički oblici, poput gotovo sveprisutnih imperativa („Shvati!“) i vokativa („Dijete!“), a kojima se, između ostalog, gramatičkim koncem i iglom uspješno kroji nevidljivi subjekt, odnosno sugovornik. 
Fonična i fonetska svojstva romana i za samu autoricu bila su od iznimnog značaja, a tome u prilog govori i činjenica da je sama prevodila englesku i francusku verziju romana, te da je 1993. godine objavila audiosnimku u kojoj čitav roman izgovara na glas (Aricò 1998, p. 158159). Formalna svojstva Fallacinog romana ukazuju na uravnotežen omjer klasičnih i subverzivnih elemenata stila, ali i na sveprisutnu naklonost retoričkim tehnikama koje ističu povezanost ženskoga tijela i glasa. ${ }^{206}$ Osnovni projekt takvoga pisma jest projekt slobode, a njega autorica unosi različitim putevima: lingvističkim, psihološkim, društveno-političkim, kulturnim, kao i moralnim i etičkim.

Pod snažnim utjecajem Sartrea i Heideggera, ${ }^{207}$ autorica ulazi u otvoreni konflikt s lijevima i desnima, s feministicama i s konzervativcima. Petchesky ${ }^{208}$ (1980, p. 661) objašnjava kako je u Fallacinom romanu majčina sloboda izbora u naravi iluzorna, odnosno ona je prvenstveno uvjetovana multifaktorijalnim pritiscima društveno-političkih oligarhija. Iako samostalna i neovisna, u odsutnosti tradicionalne bračne zajednice, ozakonjene i podržane od strane državnih institucija, žena koja pokušava sama iznijeti trudnoću spontano je i neprimjetno izbačena na margine društvenog poretka. Upravo se iz te rodne krize, uronjene u opću krizu pojedinca koju je 40-ih i 50-ih godina najavljivao francuski egzistencijalizam, javlja jedan novi val „feminističkog egzistencijalizma“ (Gatt-Rutter, 1996, p. 78), koji dvojbu subjekta o vlastitom bitku prevodi u dvojbu i konačnu odluku subjekta o bitku onog Drugog, unutar vlastitog tijela. Egzistencijalni Angst ${ }^{209}$ od „ne biti“, vezan uz Ja, u romanu Oriane Fallaci pretvara se u strah od „ne biti“ vezan uz Ti, ali istovremeno i u strah od „biti“ (gestacije), uzrokovan prije svega nepovoljnim vanjskim uvjetima i utjecajima. Taj ambivalentan odnos Ja, Ti i Mi, koji čini okosnicu teksta, objašnjava ujedno i krizu ženskog subjektiviteta te nužnost njegove potpune rehabilitacije.

Frojdovska i lacanovska psihoanaliza govore o prekidu imaginarne simbiotske povezanosti majke i djeteta ulaskom oca kao trećeg. Organska fuzija dvaju organizama koja su mjesecima

\footnotetext{
${ }^{206}$ Cixous (1977b) govori o ženskom pismu kao o ispreplitanju Imaginarnog i Simboličkog. U Imaginarnom se prostoru osjeća snažna prisutnost ženskog glasa i njegova veza s tjelesnim, dok se unutar Simboličkog prostora, obilježenog faličkim znakovima i zakonima, oformljuju kategorije poput vremena i prostora (p. 18).

${ }^{207}$ U autobiografskoj zbirci intervjua Gli antipatici (1963) Fallaci izjavljuje kako se u svojim mladenačkim godinama otkrila unutar Sartreovog egzistencijalizma (p. 99).

${ }^{208}$ Petchesky, R.P. (1980), »Reproductive Freedom: Beyond A Woman's Right to Choose«, u: Signs: Journal of Woman in Culture and Society, 5.4, p. 661.

${ }^{209}$ Prev. strah.
} 
bila u najužem mogućem fiziološkom kontaktu, činila dijete u potpunosti ovisnim o majci, ulaskom simboličkog poretka i zakona oca, prema tradicionalnoj je psihoanalizi zaustavljena. Taj prekid, posredstvom trećeg, omogućuje djetetu uspostavu subjektne pozicije, odnosno ulazak u prostor simboličkog te pristup jeziku i kulturi, ali ga istovremeno i štiti od negativnog učinka dugotrajnog patološkog stapanja, koje bi, prema mišljenju ovih psihoanalitičara, moglo dovesti do razvoja neuroza i psihoza. Ipak, je li za učinak izgona iz raja, traumatskog isključenja iz ugodnog imaginarnog simbiotskog prostora u kojem dijete uživa povlašten položaj apsolutne zaštite, uistinu zaslužan upad oca kao trećeg ili se odvajanje između majke kao prve i djeteta kao drugoga odvija mnogo ranije?

Označavajući majku kao organizam koji ugošćuje, dakle prvi, nekog sastavljenog od različite, dvonalične, antigenske kombinacije, dakle drugog, Luce Irigaray placentu, središnji komunikacijski prostor između majke i djeteta, označava kao „treći“. Prema Irigaray, taj kanal koji istovremeno razdvaja i spaja, štiti i osnažuje, u naravi priprema za trenutak konačnog odvajanja majčinog „sebe“ od djetetovog „drugog“, za prekid simbiotske veze, odnosno za trenutak traumatskog poroda, izlaska iz imaginarnog vodenog prostora majčine utrobe $u$ simbolički svijet znakova i zakona (Irigaray 1990, p. 33-34).

Osim ove filozofske perspektive, Pismo nerođenu djetetu na određen je način hommage nikad dosanjanom snu o majčinstvu. Činjenica da nikad nije uspjela postati majkom proganjat će Fallaci do kraja života. Aricò (1998, p. 161) ističe kako mu je, u nekoliko neslužbenih razgovora, više puta povjerila kako se osjeća „kao biljka bez cvjetova, kao stablo bez plodova, kao netko tko nije uspio posaditi sjeme vlastitog sebstva." Pismo nerođenu djetetu jedino je što autorica uspijeva ostaviti kao vlastito naslijeđe za buduće generacije, jedini fragment njezine ličnosti koji će i nakon njezine smrti ostati živjeti: „Kada umrem, voljela bih da iza mene ostane dijete. Barem ono načinjeno od papira“ (Fallaci u: Carrano 1978, p. 90-91). ${ }^{210}$

\footnotetext{
${ }^{210}$ Carrano, P. (1978) »Oriana Fallaci« u: Le signore grandi firme, Rimini-Florence: Guaraldi, p. 69-102.
} 


\section{KOLONIZACIJA ŽENSKOG SUBJEKTA}

\section{I. OTVORENA TEKSTUALNOST}

\section{I. I. Glas Drugog}

Promjena cjelokupne sociokulturološke paradigme 60-ih i 70-ih godina, načina medijske, literarne, ali i interpersonalne komunikacije, dovela je do radikalnih izmjena u novinarskom sektoru. Politički izuzetno turbulentno razdoblje svjetske povijesti, karakterizirano snažnim otporom svim oblicima kulturne hegemonije, potaklo je razvoj i bujanje nekih novih žanrova, stilova i oblika unutar novinarstva, poput struje New Journalisma ${ }^{211}$ (Novog novinarstva) kojemu se, najčešće zbog njegovog neformalnog preklapanja s literarnim žanrovima, u sve većoj mjeri priključuju žene.

I dok je novinarska struka, sve do pojave New Journalisma, podrazumijevala vrlo jasno određenu granicu s umjetničkim sektorom, kao i precizno određene metodološke prakse, u sklopu ove nove varijante književnog novinarstva (literary journalism) razvijaju se diskurzivne metode koje dotadašnje rigidne i konvencionalne estetske kriterije zamjenjuju izvantekstualnim i kontekstualnim metodama analize, ${ }^{212}$ pri čemu do potpunog izražaja dolazi prijenos autentičnog ljudskog iskustva. U tom smislu, novinarski tekst nije više formalan prostor skupa znakova i označivanja, već postaje prostor interpretativne kooperativnosti, prostor u kojem intersubjektivnost $\mathrm{i}$ autorska iskustvena saznanja, odnosno njegova ili njezina intelektualna pristranost, dolaze do izražaja.

\footnotetext{
${ }^{211}$ Novinarski stil pisanja, osobito popularan 60-ih i 70-ih godina, koji njeguje nekonvencionalne literarne tehnike unutar novinarskog. Ovaj nov novinarski stil karakterizira izražena autorska subjektivna perspektiva kojom do izražaja dolazi „način“, a ne više „,̌injenica“. Naziv New Journalism prvi se put pojavljuje u zbirci novinarskih članaka koje je Tom Wolfe objavio pod naslovom The New Journalism, a obuhvaćao je radove nekoliko tada eminentnih novinara: Trumana Capotea, Normana Mailera, Joan Didon, Terryja Southerna, Gaya Talesea i drugih. Radovi pisani u ovom novom novinarskom stilu većinom nisu izlazili u uobičajenim dnevnim novinama, već u specijaliziranim časopisima, poput New Yorkera i Rolling Stonea ili u zasebnim zbirkama. Neki su kritičari (Aricò, 1986) aktere New Journalisma smatrali više sociolozima i psihoanalitičarima nego novinarima. Početkom 80-ih ovaj je stil pisanja u velikoj mjeri iščeznuo.
}

${ }^{212}$ Analytic journalism: novinarski stil, u velikom dijelu temeljen na strategijama raznih društvenih disciplina, koji privilegira tzv. analitičku metodu, odnosno detaljnu analizu uzroka nastanka određenih činjenica i pojava. Analitičkim pristupom publika se indirektno usmjerava i poziva na dublje i kompleksnije razmišljanje i razmatranje određenih problema. Do osobitog izražaja, unutar analitičke metode, dolazi i metoda kritičkog razmišljanja, kao i znanstvenoistraživački pristup. 
Subjektivizam, lingvistička subverzivnost i polimorfnost ovog novog novinarskog stila, osobito su privukli i Orianu Fallaci, poglavito u godinama kada su njezin interes za liberalni socijalizam i oslobođenje žene bili u punoj snazi. Žudnja za oslobađanjem od političkih i kulturnih oblika represije u tadašnjim se Fallacinim novinarskim tekstovima sve češće zrcali i na formalnim, lingvističkim, razinama. Najuspješniji novinarski tekstovi, na gotovo nevidljivoj granici znanstveno-analitičkog i literarnog, kojima Fallaci inaugurira ulazak u tada još uvijek „muški svijet“ novinarstva, nakon njihovog prvog službenog objavljivanja u talijanskom Europeu, naknadno su sakupljeni i objavljeni u dvije opsežne zbirke tekstova pod nazivom Gli antipatici (1963) te Intervista con la storia (1974).

Obje zbirke tekstova, bez obzira na njihovu sadržajnu različitost, kao i političku orijentaciju, predstavljaju neke od temeljnih formalnih aspekata New Journalisma. Ovi nekonvencionalni romansirani artistički biografski članci, u gotovo jednakoj mjeri vode dijalog s novinarskim žanrom, kao i s literarnim estetskim vrijednostima, što uvelike otežava njihovu kritičku evaluaciju. Tog problematičnog odnosa, dviju tehnički različitih vrsta pisanja, svjesna je i Oriana Fallaci, te možda upravo zbog ovakve formalne nepogode uvijek decidirano inzistira na nužnosti isticanja umjetničkih estetskih vrijednosti njezinih snimljenih intervjua. De Stefano (2015, p. 185) ističe kako Fallaci nikad nije bila osobito oduševljena činjenicom da je publika doživljava kao novinarku. Sebe je smatrala piscem (scrittore), a svoje intervjue umjetničkim tekstovima s jasno određenom narativnom dinamikom i strukturom: „To su intervjui jednoga pisca, začeti imaginativnom sposobnošću jednoga pisca, vođeni senzibilitetom jednoga pisca“" (Fallaci u: De Stefano 2015, p. 185). Gatt-Rutter (1996, p. 8090) napominje kako je u beskonačnoj polemici o literarnim estetskim kriterijima Fallacinih intervjua te mogućnosti objektiviziranja njezine umjetnosti možda najveću ulogu odigrala razina orkestracije govornog glasa, glasa koji je potom naknadno artistički oblikovan te grafički transkribiran, zadržavajući pritom, upravo u svojim fonetskim i fonološkim karakteristikama, esencijalnost umjetničkog (auto)portretiranja.

Fallaci je šezdesetih i sedamdesetih godina sve najznačajnije intervjue, one s vodećim svjetskim moćnicima, političarima i osobama iz estradnog svijeta, snimala na zvučnoj vrpci, ne bi li dobila što intimniji i što autentičniji izvor njihovih, u velikoj mjeri iznuđenih, biografija. Ti su, s psihološkog aspekta iscrpljujući, razgovori u prosjeku trajali četiri do šest sati (De Stefano 2015, p. 185), a ponekad, kao u slučaju intervjua s Indirom Gandhi (p. 188), diskusija je mogla potrajati i više dana. Autorica objašnjava (p. 188-189) kako joj je 
korištenje zvučne vrpce omogućilo da naoko jednolično dokumentarističko štivo poprimi karakteristike osobne ispovijesti, odnosno umjetničkog dnevničkog zapisa, što zbog mogućnosti da joj upravo glas sugovornika, njegova boja, ton, opseg, jasnoća, toplina ili odsutnost, otkrije njegov psihološki status, što zbog činjenice da joj snimanje omogućava istodobno skretanje pozornosti na sve one paratekstualne elemente razgovora, sugovornikovu posturu, motoričke geste, mimiku, tikove i lapsuse koji bi u protivnom prošli nezapaženo. No, Fallacini intervjui, dodaje Aricò (1998, p. 156), više su od zvučnog zapisa kojima autorica zasigurno vrlo uspješno portretira svoje sugovornike. Prema njegovom mišljenju, u Fallacinom slučaju, nije toliko bitno što je snimljeno, već kako je snimljeno, odnosno što je sve prethodilo i što sve obuhvaća ove, gotovo kazališne ili filmske, komade u kojima se prepliću povijesno i psihološko, narativno i interpretativno, monološko i dijaloško. Sve ono što je zvučna vrpca zabilježila, kao i ono što je njezino autorsko oko tijekom razgovora opazilo, Fallaci pretvara u grafički oblik, najčešće sama prevodeći bilješke sa stranih jezika, engleskog ili francuskog, na talijanski, a potom, poput tekstualne organizacije kazališnih komada, kroji, izuzima, umeće, određuje alternativne interpunkcijske stanke, prozodijske elemente, ne bi li ostvarila željenju ritmičnost, dinamiku i dramatičnost teksta:

\footnotetext{
Ne osjećam se, niti ću se ikada osjećati, hladnim zapisničarem onoga što čujem i što vidim. Unutar svakog od mojih poslovnih iskustava ostavljam dijelove duše, unutar onog što čujem i što vidim sudjelujem kao da me se svaka od tih stvari osobno tiče ili se jednostavno očekuje da zauzmem vlastito stajalište. (Fallaci 1974, p. 7)
}

Fallacini intervjui nastaju kao sprega istraživačkog i stvaralačkog, prostor u kojem se dijaloško pretvara u monološko, dokumentarno u literarno. U tako kompleksnoj tekstualnoj formaciji, krucijalno pitanje nije ono estetskih kvaliteta i literarnog kanona, već je to pitanje kvantitativnog i kvalitativnog psihološkog otiska autoričinog glasa, glasa sugovornika koji sama autorica interpretira, te koji, u tom smislu, postaje glas Drugog. Upravo iz tog razloga Aricò (1998, p. 126) jasno i nedvojbeno ističe kako je gotovo nemoguće imitirati Fallacine tehnike intervjuiranja. One su specifičan produkt jedne neobične mlade žene, rođene $u$ specifičnim ratnim okolnostima, odgojene na osebujan liberalno-ljevičarski način, žene koja je sanjala spisateljsku karijeru, radila kao novinar i ratni izvjestitelj, te često boravila u egzotičnim, ratom zahvaćenim, prostorima. Autoričina sociokulturna orijentacija, objašnjava Aricò, stvorila je preduvjet za tako neobičan pristup novinarskim i literarnim iskustvima. Originalnost i neponovljivost Fallacinih intervjua, zaključuje Aricò, sadržane su upravo u 
osobnom pečatu, u mislima, osjećajima i odlukama, kojima autorica obavija odgovore svojih sugovornika, diskretno penetrirajući njihov subjektivni doživljaj, njihovu biografsku istinu.

Simone de Beauvoir (2001, p. 33-34) tvrdila je kako svaku umjetničku produkciju uvjetuju iskustva te osjećaj društvene, političke i osobne slobode. Iz njih, prema njezinom mišljenju, svaki umjetnik crpi svoju stvaralačku energiju, dovodeći u blizak odnos vlastito sebstvo s imaginativnim kreativnim procesima. Kao emancipiranoj i slobodoumnoj ženi s bogatim i šarolikim životnim iskustvom, Fallaci zasigurno nije nedostajalo ambicije i motivacije nužne za pokretanje stvaralačke ekspresije. Od samih početaka novinarske karijere, uronjene i uklopljene u dominatno muški svijet ratnih i političkih okolnosti, agilno i samouvjereno djeluje i stvara, pritom nimalo ne zatomljujući svoju žensku i ženstvenu stranu, već naprotiv, suptilno i intuitivno, služeći se njima kao svojom najvećom prednošću: „Oriana se uspješno snalazila u svakoj situaciji, čak i onoj ekstremnoj, ali ono što nikad neću zaboraviti, usprkos svemu, bila je njezina ženstvenost“ (Pelou u: De Stefano 2015, p. 151). De Stefano ističe kako je Fallaci, koračajući ratnim ruševinama Vijetnama, ponosno nosila vlastitu ženstvenost, baš kao i urođenu znatiželju (p. 150).

Već od prvih značajnijih novinarskih iskustava Fallaci postaje svjesna svojih komparativnih, ženskih i ženstvenih, vrijednosti i ne libi ih se koristiti: „Žena sam. To pomaže [ ... ] Imam instinkt i njime se služim kad ljude intervjuiram. Zamišljam njihove osjećaje“ (p. 189). David Sanford (1975, p. 102), analizirajući njezine najznačajnije i najuspješnije intervjue s poznatim svjetskim moćnicima, koristi termin surgical journalism (kirurško novinarstvo) kako bi objasnio taj minuciozan i vrlo precizan proces psiholingvističke obdukcije kojom autorica intuitivno penetrira misli svog sugovornika ne bi li došla do što egzaktnije informacije. Sanford ističe kako je Fallaci uvijek vrlo iskreno i potpuno svjesno koristila psihološke prednosti vlastitog spola, poglavito istančanu intuiciju i iskrenu empatiju, kako bi u potpunosti razoružala sugovornika, nedostupno učinila dostupnim, osobno učinila javnim, pritom nimalo ne negirajući intenzivnu invazivnost, provokativnost, pa čak i manipulativnu stratešku metodologiju: „Svjesna sam činjenice da vršim svojevrstan psihički pritisak na sugovornika“ (p. 102). Izuzetan talent, sposobnost emotivne prilagodbe i gotovo nepogrešive psihološke procjene, omogućili su Fallaci da najmoćnije svjetske političare, poput prvog Nixonovog savjetnika Henrya Kissingera, učini ranjivim i izloženim. 
Henry Kissinger, ${ }^{213}$ američki nadčovjek nadnaravnih sposobnosti, kako ga Fallaci opisuje (Fallaci 1974, p. 15-16), političar koji je postizao nemoguće dogovore s nemogućim ljudima, koji je određivao ritam rata jednako kao i odluke američkog predsjednika, u jednom od poznatijih intervjua ${ }^{214}$, sakupljenih u zbirci Intervista con la storia (Razgovori s poviješću), naivno posrće i upada u Fallacinu zamku pitanja, ne shvaćajući kakvome se problemu trenutno izlaže. Procjenjujući Kissingera kao muškarca koji pažljivo njeguje odnos s vlastitim egom kolosalnih proporcija (p. 15), Fallaci mu podastire pitanje o uzrocima njegove planetarne popularnosti i slave, na što on naivno odgovara „Moram biti iskren. Glavni razlog tome jest činjenica da sam uvijek djelovao sam. To se Amerikancima osobito dopada. Dopada im se kauboj koji vodi karavanu jašući vlastitog konja, ulazeći sam u gradove, u sela, sam na svome konju, i gotovo“ (p. 35). Ova „kaubojska macho izjava“ (Aricò 1986, p. 588), kojom je Kissinger slikovito pokušao objasniti razloge uspjeha svoje diplomatske karijere, dovele su do snažnog otpora i revolta američkih građana, a naravno i samoga predsjednika, Richarda Nixona, kojem se Kissingerov opis samog sebe kao usamljenog jahača nije nimalo dopao.

Fallacin strastven i uvijek pristran novinarski stil, kojim svaku izgovorenu riječ umata u vlastita razmišljanja i osjećaje, nadilazi dotadašnja pisana i nepisana pravila novinarske profesije, o čemu često i sama svjedoči, ističući kako u intervjuima ne ostavlja samo stajališta i procjene već mnogo više od toga, ostavlja vlastitu dušu i osjećaje (Fallaci u: De Stefano 2015, p. 184). Za nju su intervjui, koje priprema i odrađuje sa značajnim psihološkim, ali i fizičkim naporom, kazališni komadi kompleksnog režijskog aspekta, u kojima se uspješno prepliću javno i privatno, te koje ona postavlja na scenu, pomno birajući udio političkog i osobnog. Njemačkog kancelara Willyja Brandta propitkuje tako o sudbini unije europskih zemalja, ali ga ujedno i zaskače pitanjem o tome plače li ikad i koliko često (Fallaci 1974, pp. 353-356; 364), a perzijskog šaha, Mohammeda Rezu Pahlavija, propitkuje o političkim zatvorenicima, odnosima s Irakom i Rusijom, o savezništvu s SAD, ali i o njegovim, navodno proročanskim, snovima i strahu od uspješnih i moćnih žena (pp. 394; 398-399; 405-407), čime svjesno sabotira njegov nepogrešiv autoritet i osjećaj strahopoštovanja koji „ovaj slabašni starčić nježne tjelesne građe“ (p. 390) u iranskom narodu uživa ${ }^{215}$. Impulzivno i

\footnotetext{
${ }^{213}$ Rođen kao Heinz Kissinger u obitelji njemačkih Židova. Po završetku studija politike i filozofije na Harvardu, okreće se vanjskoj politici i postaje glavnim savjetnikom čak tri američka predsjednika: Kennedyja, Johnsona i Nixona.

${ }^{214}$ Fallaci, O. (1965a) L'ultimo cowboy. Europeo, br. 48, 28. studenog, p. 76-84.

${ }^{215}$ Fallaci, O. (1973) Lo scia di Persia. Europeo, br. 44, 1. studenog, p. 82-91.
} 
teatralno, injektirajući elemente melodrame, kako bi zadržala pozornost publike, Fallaci uspješno manevrira ove gotovo scenski strukturirane razgovore u kojima, kao i uvijek, do osobitog izražaja dolazi njezin personaliziran, nekonvencionalan, ženski i ženstven, stil pisanja.

Da su Fallacin prepoznatljiv izraz i stil prvenstveno temeljeni na činjenici da je autorica unosila cijelu sebe, svoje misli i osjećaje, u tekst koji je krojila, objašnjava i Gloria Emerson (1980, p. 334). U tom moru klasičnih američkih novinarskih članaka, ističe Emerson, kojima su osnovni ciljevi nepristranost, objektivnost, sažetost i esencijalnost informacije, Fallacini tekstovi, prožeti snažnim intelektualnim i emotivnim nabojem, dolaze pred publiku kao pravo osvježenje. Ovakav revolucionaran potencijal, koji Fallaci kroz čitavu novinarsku, ali i spisateljsku, karijeru vrlo uspješno ostvaruje, prema mišljenju nekih kritičara (Aricò 1986, p. 593), u velikoj je mjeri određen i marginalnom subjektnom pozicijom koju autorica zauzima u odnosu na centralizirane strukture društvene moći. Fallacino disidentstvo, kao Europljanke koja boravi i radi na američkom kontinentu, ali i kao žene koja djeluje i stvara u tada još većim dijelom muškoj profesiji, nameće se kao njezina najveća prednost, kao nepresušan izvor inspiracije, a reperkutira se na razini lingvističke subverzije, odnosno lingvističkog disidentstva (Kristeva 1977b, p. 3-8), kojom autorica ocrtava vlastitu marginalnu lingvističku poziciju u odnosu na etabliran patrijarhalan sustav znakova i označivanja. U psihoanalitičkim terminima, Fallacino prededipsko, decentralizirano i subjektivizirano žensko pismo, omogućuje uspješnost različitih političkih i društvenih tema o kojima, najčešće u obliku novinarskih članaka, autorica progovara.

I dok je Fallacina pozicija u odnosu na cjelokupan društveni kontekst šezdesetih i sedamdesetih godina u SAD-u pozicija disidenta, njezin položaj u odnosu na sugovornika unutar tekstualnog nešto je drugačiji. Gatt-Rutter (1996, p. 95) primjećuje kako je konačan produkt govorne interakcije Fallaci i njezinih intervjuiranih sugovornika autorica sama. Ona je, na neki način, glavni lik teksta koji priprema, u njemu se zrcale njezin karakter, odvažnost i hrabrost, njezina ustrajnost u namjeri da raskrinka sve lažne ideologije i besmislene tabue. Opisujući one, među rijetkima izabrane da vode i mijenjaju lice svijeta, one koji ni po čemu nisu bolji, snažniji i prosvjetljeniji od onih kojima upravljaju (Fallaci 1974, p. 8-9), Fallaci opisuje vlastitu sebe. Njezin glas, nositelj najdubljih slojeva psihe u kojem su fizički materijalizirana sva razmišljanja (Cixous 1975b, p. 251), ,gotovo u potpunosti preplavljuje glasove sugovornika“ (Gatt-Rutter 1996, p. 93). Ta prodorna moć ženskoga govornog glasa, 
apsolutna sloboda i nepobjedivost vokalnog, zarobljenog unutar granica tekstualnog, ukazuje na povezanost ženskog pisma, kao izravnog i samoidentičnog nastavka govornog čina (Cixous 1975c, p. 170), s tijelom. Fallacin glas, medij putem kojeg seksualno prodire u tekstualno, pretvara njezine tekstove u prostor užitka (Jouissance) ${ }^{216}$, odnosno u prostor razmjene s Drugim (Autre). Taj gotovo libidan čin, kojim autorica artikulira vlastitu žudnju $(\text { Désir })^{217}$ u jeziku, tekstualan prostor znakova i označivanja pretvara u erotogeni prostor razmjene libidne energije, prostor u kojem autorica, kako često i sama ističe, u cijelosti opušta vlastite libidne porive (Bonfante 1975, p. 72), te se, kao i prilikom seksualnog zavođenja i trenutka tjelesnog uzbuđenja, u potpunosti prepušta Drugome:

Za mene je intervju ljubavna priča. Borba. Coitus. (Fallaci u: Bonfante 1975, p. 72)

\footnotetext{
${ }^{216}$ Lacan, J. (2017).

${ }^{217}$ Lacan, J. (1992).
} 


\section{I. II. Fallacin Pendulum}

Jedan od događaja koji je obilježio šezdesete godine prošloga stoljeća utrka je za odlazak u svemir, odnosno međunarodna bitka za prvo osvajanje Mjeseca. 1957. godine tadašnji SSSR lansirao je u Zemljinu orbitu satelit imenom Sputnjik ${ }^{218}$ i od tog trenutka između Amerikanaca i Rusa započinje znanstvenoistraživačko nadmetanje, dokazivanje vlastite vojne, obrazovne i ekonomske nadmoći. ${ }^{219}$

Kao i uvijek, ovaj tihi rat vode i strateški promišljaju muškarci. Opčinjena mogućnošću njihove značajne uloge u otkrivanju novih, dotad u potpunosti nepoznatih, svjetova, Fallaci žudi upoznati nove heroje svoga vremena, astronaute koji žive i rade u posve neuobičajenim, strogo znanstvenim, zatvorenim uvjetima. Umorna i zasićena od tadašnjeg hollywoodskog mondenog načina življenja, kupanja u bazenima prijatelja glumaca, pisanja članaka o medijski slavnim osobama, o međunarodnim političkim spletkama, o lijevima i desnima, glavnom uredniku talijanskog Europea predlaže da zajedničkim snagama prate ovaj revolucionaran događaj. De Stefano (2015, p. 113-114) napominje kako je Fallaci oduvijek vjerovala u moć i važnost znanstvenog i tehnološkog napretka, te je, prisjećajući se kako je kao dijete uživala u romanima Julesa Vernea, često govorila „od ovog svijeta koji me okružuje ništa mi se ne dopada osim znanstvenih postignuća“" (p. 114). Odlučna u namjeri da svjedoči i ovjekovječi te prekretne trenutke u povijesti čovječanstva, uz pomoć moralne i financijske podrške uredništva Europea, godine 1963., a potom opet 1964., odlazi na nešto dulji privremeni boravak u NASA-in centar na Floridi. U tom, u odnosu na druga razdoblja autoričinih ratnih i turbulentnih privatnih iskustava, prilično mirnom jednogodišnjem razdoblju, obilježenog istraživačkim radom, Fallaci otkriva novu sebe. Druži se s astronautima, zajedno objeduju, izlaze, vode duge filozofske rasprave, što za samu autoricu znači ulazak u još jedan svijet rezerviran za pripadnike muškog spola.

\footnotetext{
218 4. listopada 1957., u Kazahstanu, povodom Međunarodne geofizičke godine.

219 Nakon sovjetskog lansiranja Sputnjika, a time i dovođenja u pitanje američke tehnološke dominacije, Amerikanci su gotovo čitave šezdesete godine, počevši od Kennedyjevog obraćanja naciji u Kongresu 1961. godine, posvetili utrci za Mjesec. Ova hladnoratovska svemirska bitka, između dviju najjačih vojnih i ekonomskih sila, obilježena je trima američkim lunarnim misijama pod nazivom Apollo, a treća, Apolo 11, misija je koja je označila prekretnicu u znanstvenom i tehnološkom napretku cjelokupnog čovječanstva. Glavni zapovjednik Apola 11 Neil Armstrong, pilot komandnog modula Michael Collins, te pilot lunarnog modula Buzz Aldrin, prvi su osvajači lunarne misije. 20. srpnja 1969. godine Amerikanci su potvrdili svoju znanstvenu i tehnološku nadmoć. Nakon četiri dana putovanja do Mjeseca, Neil Armstrong prvi je čovjek koji je zakoračio na njegovu površinu, izgovorivši slavnu rečenicu koja je ušla u povijest: „Malen korak za čovjeka, velik za čovječanstvo“. Ovaj je događaj izravno pratilo više od pola milijarde ljudi diljem svijeta, što je, obzirom na činjenicu da je televizijski medij bio mnogo manje zastupljen nego danas, uistinu mnogo.
} 
Plodovi ovih novih iskustava brojni su zanimljivi članci koje je Europeo tada redovito objavljivao, ${ }^{220}$ te dvije knjige, na granici znanstvenog eseja i književne proze, objavljene 1965., Se il Sole muore, odnosno 1970., Quel giorno sulla luna. ${ }^{221}$

I dok je, s književnoteorijskog i lingvističkog aspekta, djelo Quel giorno sulla luna nešto jednostavnije i popularnije koncipirano, želeći njime doprijeti do širokih masa, ${ }^{222}$ roman-esej Se il Sole muore predstavlja se kao kompleksan spoj znanstvenih reportaža i realističkog romana, fikcije, odnosno kreativnog pisanja i povijesno-dokumentarističkog: ,njezina peta u nizu knjiga, dotad najzreliji i najcjenjeniji Fallacin rad“"(Aricò 1998, p. 71).

Kao sva Fallacina djela, ovaj je roman, također, snažno autobiografski označen. Zamišljen kao hvalospjev znanstvenim postignućima čovječanstva, strukturiran kao dugačak dijalog koji autorica vodi sa svojim ocem, Edoardom Fallacijem, već nakon prvog objavljivanja predstavljao je izazov za tadašnje kritičare, a velika se pomutnja stvorila i oko pokušaja da ga se žanrovski uklopi, jasno kategorizira i odredi. Tome svakako nije pridonijelo ni sociokulturološko ozračje koje je Italija od sredine šezdesetih, pa sve do konca sedamdesetih, živjela. Naime, u tom razdoblju na kulturnu se scenu, s velikim uspjehom, probijaju djela koja sadržajno uporište nalaze u povijesnom i dokumentarističkom, a velik je i međunarodni utjecaj uzlaznog trenda New Journalisma s Tomom Wolfeom na čelu. Neki su kritičari tako, već nakon prvih recenzija ovog neobičnog romana, ipak pokušali odrediti žanrovski pravac i strukturu. Domenico Porzio (1965) govori tako o atipičnom romanu-eseju (un romanzo saggio atipico) ističući, međutim, kako se dotična „metamorfoza“ iz reportažnog (inchiesta) u roman (romanzo) ne tiče isključivo djelomičnog prelaska iz formalno novinarskog oblika pisanja u narativne konvencije klasičnog romana, pretvaranja sugovornika u lik, pitanja i odgovora u romansirane dijaloge, činjenica u zaplet, već se poglavito tiče autoričinog osobnog moralnog i psihološkog otiska. Maurice Dolbier (1966), u nemogućnosti da jasno odredi žanrovsku pripadnost, nešto opreznije od Porzija izjavljuje: „ne radi se o romanu, ni o eseju, radi se o jednom potpuno novom obliku pisanja“, a David Snell (1966) Fallacinu priču

\footnotetext{
220 Zahvaljujući Fallaci časopis Europeo zaradio je ekskluzivno pravo da u Italiji redovito izvještava o svemirskoj utrci i bitci za Mjesec (Aricò 1998, p. 244). Među brojim Fallacinim člancima, ponajviše se ističu $L a$ più grande avventura del secolo (1969b, Europeo, br. 28, 10. srpanj, p. 44-51), I nostri inviati sulla luna (1969c, Europeo, br. 29, 17. srpanj, p. 42-58), te Il giorno dopo (1969d, Europeo, br. 30, 24. srpanj, p. 43-56).

${ }^{221}$ Ako Mjesec utihne (1965) te Onaj dan na Mjesecu (1970) nisu prevedene na hrvatski jezik.

${ }^{222} \mathrm{Na}$ nagovor izdavačke kuće Rizzoli, koja je objavila sve njezine knjige, Fallaci je u drugome izdanju knjigu adaptirala za djecu i mladež, te je roman uvršten na popis lektire u talijanskim školama.
} 
o Suncu koje bi moglo umrijeti i ugasiti život na Zemlji, uspoređuje s Hemingwayevim autobiografskim putopisnim dnevnikom objavljenim 1935., The Green Hills of Africa (Zelena brda Afrike).

Pokušavajući Fallacino djelo čitati u suprotnom smjeru klasičnih struja, zanemarujući tadašnje žanrovske konvencije, neki su kritičari ipak uspjeli premostiti onaj duboki jaz između institucionalne i neinstitucionalne kritike, odnosno oformiti potpuno nov pristup tekstu, uzimajući u obzir kontekstualne, paratekstualne i izvantekstualne odrednice, društvenokulturne, političke i moralne okolnosti. Odudarajući tako od rigidnog programa američke nove kritike, roman Se il Sole muore spontano iziskuje uključenje nekih iskustvenih saznanja iz područja izvan dometa klasičnog metodološkog alata (Showalter, 1979; 1981).

Glavni toposi Fallacinog bestsellera američka je znanstveno-istraživačka postaja John F. Kennedy, te Cape Canaveral lansirni centar na Floridi. Tijekom jednogodišnjeg boravka s američkim astronautima autorica prikuplja sve informacije o njihovom istraživačkom, ali i obiteljskom i emotivnom, iskustvu, pokušavajući prodrijeti do što dublje i kompleksnije psihološke karakterizacije njihove osobnosti. Kao i uvijek, razgovor s ovim savršenim bićima koja se rijetko kad smiješe (Fallaci, 1965b) bilježi na zvučnoj vrpci, te naknadno prepisuje, obraćajući posebnu pozornost na njihov ljudski, ne toliko znanstveni, aspekt. Intervjue NASA vremenski ograničava, dostupno je ukupno osam astronauta, od kojih je samo jedan, Pete Conrad, od samoga početka prilično otvoren i pristupačan.

Aricò (1998, p. 82) tvrdi kako se uspješnost ovih razgovora krije u činjenici da je Fallaci, za razliku od nekih njezinih kolega novinara, zakoračila onkraj uobičajenog portretiranja ovih znanstvenih ikona 20. stoljeća. Osim opisa njihovog izgleda, psihofizičke spremnosti i obrazovnih kvalifikacija nužnih za sudjelovanje u projektu svemirske ekspedicije, autorica posebnu pozornost posvećuje duševnom i emotivnom utisku, koji ovi neobični znanstvenici na nju ostavljaju, uobičajeno umećući vlastita razmišljanja, komentare, moralna i egzistencijalistička stajališta, predstavljajući se, na taj način, kao „moralni autoritet“ (p. 82) koji balansira između znanosti i kulture, kulture i prirode. I ovoga puta autoričin glas dolazi do punog izražaja. Injektirajući u tekst vlastite autobiografske podatke, o ocu i majci koji nisu prihvaćali tehnološki napredak i svijet u kojem svi žure i ne obaziru se, o netaknutoj prirodi njezine rodne Toscane, o fatalnoj privlačnosti koju je oduvijek osjećala prema dalekoj joj Americi, obećanoj zemlji u kojoj svatko marljivim radom postiže zagarantiran uspjeh, Fallaci, 
na neki način, portretira i projektira sebe, tako da se tekstovi o lunarnom poduhvatu američkih astronauta više ne mogu smatrati jednostavnim rezultatima istraživačkog novinarstva, već „kompleksnim mozaikom unutar kojeg se prepliću život Oriane Fallaci i njihov život“ (p. 92).

Tom Wolfe (1973, p. 188) ${ }^{223}$ tvrdi kako svaki put kada pisac, čiji tekst nije jasno označen kao strogo literaran, zauzme autobiografski pristup, spontano pretvara sebe u lik, u djelić sveukupne narativne strukture teksta. To upravo čini Oriana Fallaci koja, unoseći vlastitu povijest, autobiografsku obiteljsku reportažu i proces vlastitog emotivnog sazrijevanja, novinarske istraživačke eseje pretvara u neobičan i prikriven Bildungsroman s elementima znanstvenog. Gatt-Rutter (1996, p. 108) ide korak dalje, ističući kako Fallaci, u ovoj priči o junacima u svemiru, nije samo autor, pripovjedač i jedan od likova. Ona je glavni glumac na pozornici. Ustoličujući egzistencijalističke dvojbe, koje zaokupljaju sva ljudska bića, kamo idemo i koja je naša uloga, autorica, na neki način, sebe ovlašćuje da, u tom duboko povrijeđenom post-Auschwitz i post-Hiroshima svijetu, putevima nekih novih i neistraženih planeta, čitateljima ponudi nadu u suživot tradicionalnih vrijednosti i moderniteta, prirode i znanosti.

U uvodnome dijelu Se il Sole muore, objašnjavajući vlastitu namjeru da ovaj neobičan dnevnik (diario) prikaže kao neprekidnu oscilaciju između ,jučerašnjih iskustava i sutrašnjih izazova“ (Fallaci 1965b, p. 8), autorica sebe opisuje kao „pendulum koji neprestance zamahuje od jedne sumnje do druge“ (p. 15). Fallacin pendulum, ${ }^{224}$ svojevrsna metafora kritičkog promišljanja, stalnog dovođenja u pitanje utaborenih i ustaljenih dogmi i kalupa, paradigmatsko je težište čitavog romana, centralna struktura koja kontrolira retoričku ravnotežu između znanosti i kulture, tekstualnog i izvantekstualnog. Gatt-Rutter (1996, p. 109) ističe kako su cjelokupan sadržaj i struktura djela koncipirani „metodom oscilacije“, neprekidne alternacije afirmativnih, negacijskih, potom reafirmativnih trenutaka, anticipirajući autobiografski „roman o sumnji“ (De Stefano 2015, p. 221), Pismo nerođenu djetetu.

Osjećaj neprekidne sumnje i neodlučnosti osnažen je uporabom dijaloga, obavijenih retorikom, ritmom, dinamikom i intonacijom govornog glasa, koji tekstualnost gotovo u potpunosti otvara i čini promjenjivom. Milani (1971, p. 30) govori o još jednoj izuzetno

\footnotetext{
${ }^{223}$ U Wolfe, T; Johnson, E. W. (1973) The New Journalism. With an Anthology. New York: Harper-Row.

${ }^{224}$ Pendola, altalena (Fallaci 1965b, pp. 15; 31).
} 
naglašenoj stilizaciji ženskoga govornog glasa, koji neprestance propitkuje i sumnja, dok obraćanje autorice u drugom licu jednine, uporaba vokativa, neformalnih kolokvijalnih izraza i tonova, jednostavne i rascjepkane sintakse, suptilno otkrivaju strategiju revidiranja i rekonstruiranja misli (Gilbert i Gubar, 1979).

Fallacin glavni sugovornik, otac Edoardo Fallaci, prikazan kao zagovornik tradicionalnih patrijarhalnih vrijednosti, uvijek apostrofiran Ti! (Tu!), iako u mnogočemu različit od intervjuiranih znanstvenika, baš kao i oni predstavnik je i nositelj dogmatskog hijerarhijskog sustava razmišljanja u kojem cjelovitost, jedinstvo i totalitet predstavljaju osnovne estetske kriterije. No, njemu se, putem dinamičnih i iscrpljujućih dijaloga, autorica energično suprotstavlja, ukazujući mu na nužnost radikalnih promjena, na potrebu da se priroda prilagodi kulturi, kultura znanosti, na nužnost poništenja dualnih proturječja i binarnih opreka. Fallaci tako u konačnici potvrđuje svoj sustav razmišljanja, koncipiran kao antifalički pendulum, uzastopnog kaotičnog gibanja, kojim nanovo svjedoči o osobitim i jedinstvenim, ali ujedno i heterogenim, ženskim i ženstvenim, vrijednostima. 


\section{II. NOMADSKA ESTETIKA}

\section{II. I. Autor in fabula}

Kontrakulturna revolucija, obilježena masovnom eksplozijom građanskih pokreta i pobuna, trajno je izmijenila lice svijeta. Otpor mlade generacije klasnim i rasnim nejednakostima, istodobnom porastu teškog siromaštva i potlačenih, te autoritarnih diktatura i povlaštenih, ali ponajviše i onom najvećem porazu ljudskosti, ljudskog razuma i razvoja, Vijetnamskom ratu, uznemirio je sve aspekte društva američkog i europskog kontinenta, te dodao osobit značaj sintagmi „suvremena ljudska kriza“ (Fromm 1977, p. 13).

Burne političke, kulturološke i medijsko-obrazovne promjene sredinom 60-ih dosegle su svoj izražajan i djelotvoran vrhunac, dovodeći u središte pozornosti pitanja poput prava na životnu sredinu dostojnu čovjeka, prava na nacionalni identitet, neovisnost i slobodu od institucionalnih represija, kao i prava na različitost, različite vrijednosne stavove i izražajne načine, različite psihološke i retoričke osobine. Iako često međusobno vrlo različite ideološke tendencije raznorodnih političkih struja i gibanja, ujedinjene i gotovo amalgamirane ostaju u nekoliko ključnih ciljeva: u želji za prekidom američke intervencije u indokineskom području, nacionalnom i socijalnom oslobođenju naroda Sjevernog i Južnog Vijetnama, te u isticanju nužnosti temeljitih i korjenitih reformi u području ljudskih i građanskih prava, uključujući poništenje rasnih, klasnih, etničkih te rodno-spolnih nejednakosti i predrasuda, kao i moralnih i političkih nekorektnosti, odnosno njihove nepravedne legitimizacije.

Vijetnamski je rat dotakao apsolutno sve sfere ljudske egzistencije, usporio je i gotovo uništio američko gospodarstvo, zaustavio brojne znanstvene i obrazovne projekte, te trajno izmijenio simboličke i kulturološke vrijednosti, a obzirom na njegov opseg i utjecaj, već od prvih godina eskalacije sukoba postaje glavna interesna odredišna postaja mnogih zapadnoeuropskih i američkih novinara, zahvaljujući kojima pojedinci razvijenog Zapada postaju svjesni važnosti i utjecaja događaja na drugom kraju svijeta.

Koncem 50-ih, odnosno početkom 60-ih, većina su novinara i fotoreportera muškarci, no nakon utemeljenja Akta o građanskim pravima, Civil Rights Act 1964., direktno povezanog i izniklog iz masovnog pokreta za ljudska i građanska prava, iz godine u godinu sve je više žena, novinarki i ratnih reporterki, koje se priključuju medijskim projektima u Vijetnamu. Iako su žene svjedočile i izvještavale već u Drugom svjetskom ratu, a nekolicina novinarki 
bila je prisutna i u Korejskom ratu, taj je broj neusporedivo malen i neznatan u odnosu na broj novinarki u Indokini. De Stefano (2015, p. 151) govori o ukupno 467 novinarki koje su obilježile cjelokupan Vijetnamski rat. Gotovo polovinu čine američke novinarke, zatim one francuske, a jedina talijanska, koja će ujedno u svijetu biti zapamćena i kao ona najradikalnija, najiskrenija i najkontroverznija, jest novinarka Europea, Oriana Fallaci.

Fallaci kreće u Indokinu 1967. godine, u svojstvu glavnog službenog ratnog izvjestitelja Europea, te, uz pomoć francuskog novinara Françoisa Peloua, u tom ratom devastiranom području bilježi svaki bitan događaj, svaku značajniju vojnu intervenciju, organizirane napade obiju strana, one komunističke, te one američkih i proameričkih snaga, ugovara i detaljno bilježi razgovore s ključnim osobama ovog kolosalnog konflikta, sastaje se sa zapovjednicima, vojnim pilotima, teroristima i njihovim obiteljima, vojnicima na prvoj liniji bojišnice, odlazi u vojne bolnice, zatvore i tamnice, učestvuje u vojnim operacijama i strateškim odlukama. Svaki detalj bilježi na vrlo osoban i uvijek osebujan način, gomilajući sav onaj radni materijal koji će poslužiti za sastavljanje članaka o Vijetnamu u talijanskom Europeu, odnosno za knjigu nastalu upravo na temelju detaljne analize, literarne obrade i preinake objavljenih članaka, koju potom objavljuje 1969. godine, pod naslovom Niente $e$ così sia 225 (Ništa i Amen).

Autobiografski roman-dnevnik Niente e così sia već je godinu dana nakon prvog objavljivanja dosegao broj od ukupno trideset izdanja te književnu nagradu Bancarella za najuspješniji roman godine (Milani 1971, p. 24). Preveden na brojne jezike, svoj velik uspjeh duguje neobičnim avangardnim kombinacijama novinarskog, dokumentarnog i literarnog. Iz oblika ratne reportaže i autobiografskog dnevnika rađa se tako novo prozno umjetničko djelo, tzv. non-fiction novel (p. 24), koji se od brojnih drugih tadašnjih zapisa o Vijetnamu razlikuje možda najviše zbog činjenice da je autorica kroz njega ,pokušala shvatiti što vojnik misli i osjeća dok ubija“ (Aricò 1998, p. 97), injektirajući istodobno literarne elemente socijalnog realizma, New Journalisma, te egzistencijalizma.

I u ovom se djelu Fallaci odupire rigoroznim pravilima tradicionalne žanrovske klasifikacije, kao i formalnom akademskom institucionaliziranom jezičnom diskursu, suprotstavljajući se, na taj način, ne samo političkoj tiraniji i nasilju komunističkog,

${ }^{225}$ Niente e così sia naslov je članka Alberta Moravije o Hemingwayu, objavljenog 1961. godine u Espressu. Ovakvim intencionalnim hommageom Hemingwayu autorica poglavito ističe onaj jednostavan i transparentan realizam narodne proze, kakav je njegovao američki romanopisac, a kojemu se Fallacin roman približava. 
američkog i proameričkog režima, koji u gotovo jednakoj mjeri devastiraju i unazađuju prostor Južnog Vijetnama, već i svakom obliku jezičnog totalitarizma, dominacije, kulturne hegemonije i opresije. Kršeći neke osnovne postulate novinarske djelatnosti, poput apsolutne nepristranosti, odmaka i objektivnosti, kronološki uređene zbilje, formalno egzaktne sintakse, te uniformiranog puristički oblikovanog leksika, ovim se romanom autorica još jednom približava nomadskoj estetici i fenomenu deteritorijalizacije. Iz novinarskog iskustva Fallaci otima sposobnost da razluči važno od važnijeg, žurno od žurnijeg, kao i sposobnost da novinarskim komunikacijskim strategijama pridobije toliko potrebnu i željenu informaciju. S druge strane, talent i naklonost literarnom omogućuju joj da u jednolično i suhoparno novinarsko štivo unese osobnu motivaciju i razmišljanja, te da svojim likovima podari jednu detaljno strukturiranu psihološku karakterizaciju. Aricò (1998, p. 107) naglašava kako takav književni pristup novinarstvu, kakav je njegovala Fallaci, šezdesetih i sedamdesetih godina nije bio novost. Književnim novinarstvom ${ }^{226}$ bavili su se i John McPhee, Tom Wolfe, Joan Didion, Richard Rhodes te Jane Kramer, svi poznati i podjednako uspješni. Ono što, međutim, Fallaci osobito ističe i čini prepoznatljivom jest unošenje cijelog vlastitog bića i glasa u tekst koji kroji po principu bricolagea, odvajajući suvišno i umećući nužno, iskazujući na taj način potpunu i neupitnu predanost tekstu kojemu služi, tako da njezin opus nije samo rezultat ostvarenih zadataka već i odraz osobnosti: „Ta neobična žena postaje vlastiti sugovornik, njezino umijeće postaje verbalna projekcija sebstva“(Aricò 1986, p. 587).

Narativni aspekt romana, kako to najčešće biva u Fallacinim tekstovima, predstavlja se još jednom izuzetno slojevit i atipičan. Uvertira čitavog romana, koja ujedno označava i njegovu filozofsku nit vodilju, sadržana je u samo jednom kratkom pitanju: „Što je život?“ (Fallaci 1969e, p. 7). U nastojanju da prikupi sve potrebne informacije i iskustva, kako bi na ovo, samo naizgled jednostavno, pitanje mogla što spremnije odgovoriti, Fallaci podastire neobičan interdisciplinaran tekstualan labirint, ${ }^{227}$ sastavljen od nekoliko međusobno različitih, a ipak povezanih struktura.

Glavni adresat, ujedno i sugovornik, onaj kojem je roman posvećen, francuski je novinar France-Pressea, François Pelou. Dijalog koji autorica u ulozi pripovjedača ostvaruje s Pelouom u funkciji je dublje psihološke karakterizacije likova te konkretnijeg razumijevanja

\footnotetext{
${ }^{226}$ Literary journalism (Aricò 1998, p. 107).

${ }^{227} \mathrm{~S}$ tehničkog aspekta, labirint sastavljen od elemenata novinarskog, autobiografskog i fikcije, odnosno literarnog.
} 
svih aspekata rata. U dijaloškom konfliktu različitih stajališta, viđenja i glasova, razaznaje se rat viđen očima muškarca (Pelou) i rat zapamćen osjetilima žene (Fallaci). Ta se primarna narativna istanca, koju obilježava svojevrsna literarna travestija ${ }^{228}$ subjektivnog promatrača koji apsorbira i pamti sve ono što Vijetnamski rat za sobom ostavlja, uokviruje uvodnim ekstradijegetskim pripovjednim notama, obilježenih umirujućim i pomirujućim tonovima, kojima pripovjedač, na neki način, uvodi i priprema čitatelja za ono što tek slijedi, iznoseći u njima vlastitu ideološku poziciju i afinitete. Svako se, dakle, pojedino poglavlje otvara vrlo kratkim retrospektivnim uvodom u prošlom svršenom vremenu, čineći tako ovaj dio romana $i$ najromanesknijim, ${ }^{229}$ a jedini glas koji čitatelj osluškuje jest onaj autoričin:

Ti znaš da ovaj dnevnik želi biti samo potvrda jednog iskustva, i ne pretendira da objasni krvavo ludilo Vijetnamskog rata. Ti znaš da je Vijetnam za mene predstavljao instrument jednog istraživanja [ ... ] Odabrala sam ga jer je njegova tragedija predstavljala jedan simbol, simbol koji je prodro u našu svakodnevicu: govorilo se o Vijetnamu da bi se govorilo o ratu, da bi se govorilo o smrti. (Fallaci 1969e, p. 212)

Radnja se potom nastavlja dnevničkim zabilješkama u prezentu, odnosno u prezent perfektu, a karakterizira je i izražena dijaloška dinamika muškog (Pelou) i ženskog (Fallaci) glasa. To je ujedno i najautentičniji topos romana, izniknuo izravno iz bilješki crnog knjižuljka ${ }^{230}$ koji autorica spominje u uvodnom dijelu šestoga poglavlja:

Znaš, kada iznova pročitam bilješke svog dnevnika, iznenada se začudim. To je jedan crni knjižuljak s izraženim kockicama ili crtama na stranicama, a rukopis koji ih ispunjava kao da mi nipošto ne pripada: gust, precizan, učen. Čak i kada sam opisivala najužasnije i najnemogućije pojave. Gdje li sam samo nalazila tu snagu da sama prolazim kroz taj nemir i užas? (p. 172-173)

U kolosijeku ovih dviju osnovnih narativnih pozicija nalaze se dnevničke zabilješke Vijetkongovaca te vojnika Sjevernog Vijetnama, putem kojih Fallaci ,secira“ društvenu zbilju, ${ }^{231}$ prenoseći događaje u sadašnjost te dopuštajući drugim glasovima da artikuliraju

\footnotetext{
${ }^{228}$ Transformacija autorske u pripovjedačku ulogu, a potom i u ulogu glavnoga lika.

${ }^{229}$ Podsjećajući, kako oblikom, tako i sadržajem, na autobiografske zapise postkolonijalnih autora.

${ }^{230}$ Original dostupan u Mugar Memorial Library bostonskog sveučilišta.

${ }^{231}$ Social autopsy (Gatt-Rutter 1996, p. 127).
} 
vlastitu zbilju i egzistencijalističke stavove, no ipak ,tehnički ih uvijek subordinirajući vlastitim diskurzivnim strategijama i konceptualnom svemiru“(Gatt-Rutter 1996, p. 125).

S naratološkog je stanovišta roman tako poprilično rascjepkan i fragmentiran u nekoliko formalno i sadržajno međusobno različitih struktura, koje kao da sve do samoga kraja nisu u potpunosti zadobile svoj konačan oblik i smisao (Cavarero, 1997). Ipak, sve su one istovremeno i međusobno povezane jednim apsolutnim, nadređenim i dominantnim lingvističkim aspektom: autoričinim glasom. Ta najupečatljivija psihološka instanca, kao u većini Fallacinih tekstova teško razlučiva od glasa pripovjedača, odraz je autoričine prodornosti, nepristranosti i potpune subjektivnosti. Snažan i upečatljiv vokalni otisak, koji ostavlja Fallacin rukopis, gotovo cijelo trajanje romana usmjerava čitatelja, nudeći konkretne moralne i etičke zaključke o tome što rat, a što život jest.

Semantički decentniji i manje eksponiran aspekt romana uokviruju dva ključna događaja. Prvi jest onaj kojem autorica posvećuje predgovor, a opisuje zvjerski masakr nevinih civila u selu May Lai, od strane američkih trupa. Drugi jest onaj kojim se djelo zaključuje, a prikazuje masakr vojske nad pobunjenim studentima u Mexico Cityju. Dva masakra, indirektno povezana s ostatkom teksta, u funkciji su semantičke, ali i statičke, podrške ostatku teksta. Uokvirujući samu srž romana, dnevničke zabilješke i pojedina poglavlja, produciraju vrlo snažan retorički efekt kojim čitatelj biva usmjeren na razmišljanja o svrsi ljudske egzistencije, o pristranom zapadnjačkom pojmu sloboda i pravu na različitost. Egzistencijalističke dvojbe i promišljanja intertekstualnim intervencijama provlače se i unutar samoga teksta dnevnika. Fokusirani na odgonetanje ljudske prirode i psiholoških granica čovjeka, ukazuju na autoričinu nesigurnost, nevjericu i osjećaj nestabilnosti koje na koncu svakoga poglavlja Fallaci i javno objavljuje:

\footnotetext{
Bože, kakva ludnica. Rat je ludnica. [ ... ] Na Saigon pljušti gusta kiša. Slijepa poput njezinih očiju, očiju Cao Kya i Nguyen Ngoc Loana, očiju moje zbunjenosti, mog razočaranja, moje uzaludne potrage za istinom koju ne nalazim, a ovdje je. [ ... ] No, prebrodila sam krizu, osjećam se gotovo spokojna. Ipak, u torbi nosim Pascala. (Fallaci 1969e, pp. 211;235; 283)
}

Fallaci je, priznaje, u Vijetnam stigla puna velikih očekivanja i nadanja da će do kraja moći razumjeti herojstvo bića koje umire za slobodu svoje zemlje, ali i zvjerstvo tiranina koje tu slobodu drugom biću otima: 
Ovdje sam da bih shvatila čovjeka, što misli i što traži čovjek dok ubija onog drugog. (p. 15)

No, kako roman kronološki napreduje, shvaća da je ta spoznaja gotovo nedostižna i da će velik dio nje ostati zauvijek izgubljen u nekom utopijskom beskraju:

Da, život, što je? Stvar koju treba dobro popuniti, bez gubljenja vremena. Čak i ako se, popunjavajući ju, razbije. (p. 354)

U romanu je izražena prisutnost patrijarhalnih simboličkih autoriteta. Spominju se predsjednici, savjetnici, vojni zapovjednici, utjecajni filozofi poput Sartrea, Pascala, Camusa i Marxa, a glavni Fallacin sugovornik, François Pelou, predstavlja se kao važan moralni autoritet, te joj upravo on daruje knjigu francuskog filozofa Blaisea Pascala, uz napomenu da čovjek nije ni anđeo ni zvijer, ukazujući time na opasnost zauzimanja konkretnih stajališta. Koračajući, međutim, opustošenim i devastiranim područjima, područjima koja su te iste patrijarhalne i kulturne elite podredile sebi i vlastitim potrebama, Fallaci se u potpunosti okreće političkom agnosticizmu i otporu političkih i filozofskih uvjerenja te propituje:

Sloboda? Možete li je zamisliti, doktore Khan? Ne. Čitao sam o njoj u Pascalovim i Sartreovim djelima. No, ne znam što je. [ ... ] Što je? Jeste li čitali Camusa? Ja se osjećam kao Stranac. Sve me to ne dodiruje odviše. [ ... ] Doktore Khan, ali Strancu odrubljuju glavu. I ta me mogućnost ne dodiruje odviše. Smrt je jedan relativan pojam. (p. 42)

Filozofija, ističe Cavarero (1990, p. 33), najuzvišenija je umna disciplina koja pripada muškom rodu, koja jedina ima sposobnost da imitira smrt, da odvoji dušu od tijela i tako oslobodi čovjeka od prizemnih ovozemaljskih strasti koje čovjeka čine životinjom. Pogled filozofa pogled je usmjeren u visinu, u onozemaljsko. Pogled filozofa pogled je nepogrešivog autoriteta kojeg čak i smrt ostavlja ravnodušnim. No, pogled Oriane Fallaci pogled je žene koja ne teži onozemaljskim idejama, već ovozemaljskim iskustvima, a njezin jezik nije jezik filozofskih bogova, već jezik stvarnosti i osjećaja: 
Voljela sam jako Mjesec, zavidjela onima koji su ga odlazili osvajati. No, sada kada ga pogledam, tako sivog i praznog od dobra, od zla, od života [ ... ] Radije imam ovu zelenu i bijelu i plavu kuglu punu dobra, zla i života, koju zovu Zemlja. Zatrovana je to kugla, znam, biti u njoj znači umrijeti, znam: život, François, osuda je na smrt [ ... ] I upravo jer smo osuđeni na smrt treba ga dobro ispuniti, bez zastajkivanja, bez straha od pogrešaka, od lomova, mi, koji smo ljudi, ni anđeli ni zvijeri, već ljudi. (Fallaci 1969e, p. 354)

Izuzetno visok stupanj stilizacije govornog glasa u koji su sva putenost ženskog i ženstvenog utisnute, prožima cjelokupan tekst. Autoričina ontološka prisutnost, u svim narativnim sekvencama, sastavlja paradigmatsku okosnicu za čitav niz autobiografskih ispovjednih trenutaka, koji će, u konačnici, oformiti roman. Istinski subjekt, ujedno i objekt teksta jest sama autorica. Ona se tekstom kreće, sad gubi, sad nalazi, te vlastitim lingvističkim iskustvom i strategijama uobličuje ono što direktno proživljava. Ona je subjekt u kontinuiranom procesu jezične tranzicije, nomadskim rječnikom, ona je vektor deteritorijalizacije, koji vremenskim i prostornim dislokacijama unutar različitih lingvističkih supstrata uspostavlja direktnu vezu autora i teksta s kontekstualnom stvarnošću.

Tu direktnu i potpunu involviranost autoričinog $J a$ u najvećoj mjeri osnažuju lingvističke tehnike slobodnog govornog čina, primarne osobine nomadske estetike, te direktno injektiranje tzv. govornih stilema u svrhu emfatizacije vokalnih karakteristika pisanog teksta. Kako je i sama autorica nebrojeno puta istaknula, njezine se konačne zabilješke ratnih zbivanja i svih dijaloga koje je vodila s vojnicima i čelnim ljudima sastoje od različitih naknadnih lingvističkih intervencija, oduzimanja, umetanja i preoblikovanja, s konačnim ciljem da ostvari što autentičniji portret likova i zbilje o kojoj isti progovaraju. Milani (1971, p. 30) ističe kako takve intervencije u konačnici neminovno rezultiraju autoričinim osobnim vokalnim i retoričkim imprintingom, uključujući neke stileme i retoričke oblike karakteristične za toskanski koiné, ${ }^{232}$ poput skraćenih dijalektalnih oblika glagola fare (činiti) i andare (ići), fo i vo, koji uistinu zvuče neobično kada ih na posve spontan i prirodan način izgovaraju američki vojnici:

\footnotetext{
${ }^{232}$ Regionalni jezik.
} 
»E prego sai, no fo che pregare.«(Fallaci 1969e, p. 25)

[I molim znaš, ne činim drugo nego li molim.]

»E vo avanti gridando ai miei uomini di non aver paura.« (p. 31)

[Išao sam naprijed vičući mojim ljudima da se ne boje. ]

»Sai quante volte fo in tempo a morire?« (p. 35)

[Znaš li koliko puta stignem još umrijeti?]

»Non fo che pensare, non fo che chiedermi.« (p. 315)

[Ne činim drugo nego li razmišljam, ne činim drugo nego li se propitkujem.]

Uz dijalektalne se skraćenice pojavljuju i brojni apokopirani leksemi, najčešće unutar deskriptivnih trenutaka, kojima se nastoji uspostaviti ritam govornog jezika. Lingvističkim incizijama dočarani su, na taj način, stilistički skokovi regionalnog jezika kojim se autorica služila:

Eppure come doveva esser bello, allegro, il Vietnam quando non c'era la guerra [ ... ] Ma perché si deve sempre sporcar la bellezza? (p. 18)

[Ipak, koliko je morao biti lijep i veseo Vijetnam dok nije postojao rat [ ... ] Zašto se ljepota uvijek mora unakaziti?]

È bello, sai qui. È bella la linea delle montagne, è bello il verde delle foreste, e lo

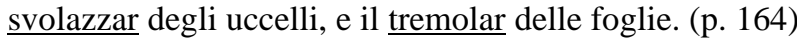

[Znaš, lijepo je ovdje, lijep je planinski niz, lijepo je zelenilo šuma, let ptica i podrhtavanje lišća.]

Fonetskoj i foničnoj specifičnosti Fallacinog nomadskog pisma pridonosi i vrlo česta uporaba deminutiva (-ino, -ina, -uccio, -uccia). Osobito korišteni prilikom portretiranja ostalih likova u tekstu, naglašavaju neformalni svakodnevni govor i autoričinu namjeru da modernizira literarni izričaj: 
Quest'omino scalzo, con la benda sugli occhi anche lui, e due spallucce fragili, due manucce magre (p. 58)

[Ovaj bosonogi čovječuljak, povezanih očiju, dvaju krhkih ramenčića, dviju mršavih ručica.]

Donnina dal volto umile (p.315)

[Ženica poniznog izraza lica.]

Col suo visuccio di povero nato per soffrire. (p. 348)

[Svojim lišcem siromaha rođenog da bi patio.]

Neobična muzikalnost i ritmičnost Fallacine proze velikim je dijelom istaknuta alternacijom uzastopnih ponavljanja i interpunkcijskih znakova, poput istaknutog paralelizma pomoćnog glagola avere (imati),

François non ha risposto. Non ha neanche rallentato. $\underline{\text { Ha }}$ continuato con quel viso di pietra. Poi ha frenato. [ ... ] $\underline{\mathrm{Ha}}$ spalancato la portiera. È sceso. $\underline{\mathrm{Ha}}$ caminato verso Loan. (p. 137)

[François nije odgovorio. Nije ni usporio. Nastavio je onim skamenjenim licem. Onda je zastao. [ ... ] Otvorio je vrata. Sišao. Hodao je prema Loanu.]

te poput narativnih amplifikacija ostvarenih prilikom uzastopnog preuzimanja određenih termina, imenica ili jednostavno regresivnog nabrajanja kojima autorica naglašava monološku i dijalošku govornu dinamiku, producirajući hijazmički efekt: ${ }^{233}$

Dentro i recinti sorgevan barracche con le cuccette a doppio piano o i materassi per terra, intorno alle barracche sostavano uomini dal volto chiuso. (p. 84)

[Unutar ograda izdizale su se kolibe s krevetićima na kat ili ležajevima na podu, uokolo koliba zastajkivali su muškarci krutog izraza lica.]

Nascosti sui monti, sulle colline, nei cimiteri, nelle capanne, nei campi, stanno i vietcong. (p. 185)

[Sakriveni u planinama, u brežuljcima, na grobljima, u zvonicima, u poljima, ostaju vijetkongovci.]

Iskrena i vrlo intimna povezanost autorice $\mathrm{i}$ čitatelja ostvaruje se i nizom talijanskih uobičajeno kolokvijalnih izraza, poput ecco (eto), ovvio (očito) te mica (nipošto, ni u kom slučaju), kojima se ističe oblik neformalnog svakodnevnog govora,

${ }^{233}$ Repeticija i kumulacija, unutar rascjepkane sintakse, prema mišljenju Hélène Cixous (1975b) neka su od osnovnih obilježja ženskog i ženstvenog pisma. 


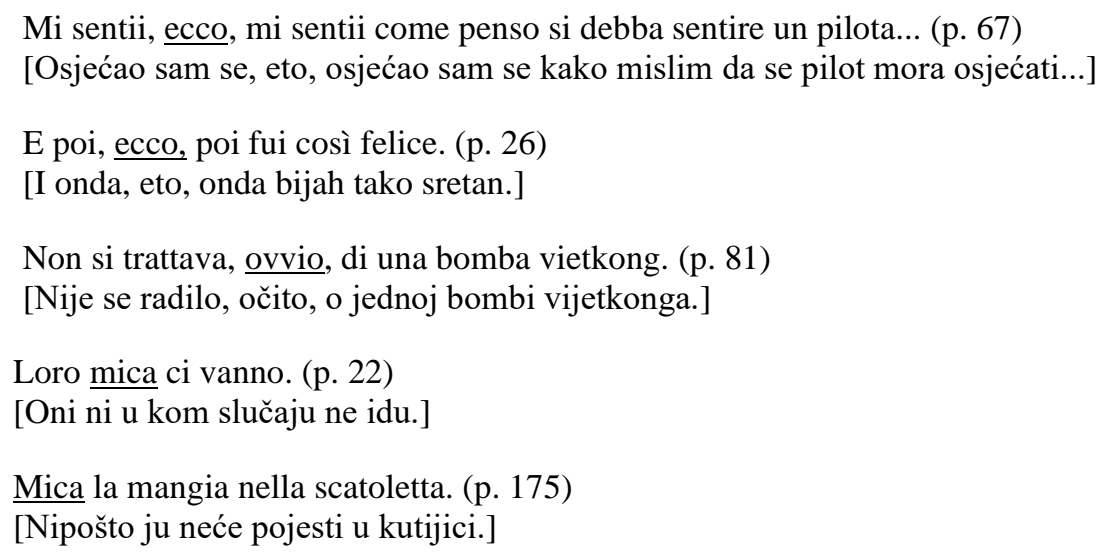

te predisponiranosti uporabi tzv. afektivnih imenica, poput imenice creatura (stvorenje), kojom se ostvaruje fiziološka povezanost s čitateljem:

\footnotetext{
... star qui impotenti a pensare che la vita di nove creature dipende da un sì o no [...] Chi pregheranno quelle nove creature? (p.13)

[Onemoćalo stojeći ovdje i razmišljajući kako život devet stvorenja ovisi o jednom da ili ne. Koga će moliti ovih devet stvorenja?]

Per me sono tutti uguali, sono creature con un naso e due braccia e due gambe... (p. 306)

[Za mene su svi isti, stvorenja s jednim nosom, dvije ruke i dvije noge...]
}

Pokazujući izražen afinitet prema određenoj demistifikaciji književnog jezika, dekonstrukciji elitnih standarda kulturnih enklava, kao i uporabi različitih nekonvencionalnih lingvističkih supstrata, prateći, kako u formalnom, tako i u sadržajnom smislu, koncept fluidnosti i fluktuirajućeg svojstva jezika, istovremeno se suprotstavljajući falocentričnim diskurzivnim metodama i stilu, Fallaci se u svakom smislu približava obilježjima nomadskog pisma. Uz još neka karakteristična svojstva tzv. antiedipske estetike, poput vremenske i prostorne deteritorijalizacije, istančane taktilne govorne retorike (Fallaci 1969e, p. 39-21,22.) te inzistiranja na dijaloškom obliku teksta, u svrhu isticanja govornog jezika, najistaknutije je svakako svojstvo autoričine fizičke i materijalne prisutnosti unutar glasa koji pripovijeda. U tom smislu, sam je tekst svojevrsna zrcalna refleksija Fallacinog $J a$, prostor kojim odjekuju apsolutna jezična sloboda, te nesputanost ženskog i ženstvenog. 


\section{II. II. (Auto)biografska subverzija}

Okončanje Vijetnamskog rata, smirivanje sukoba na Bliskom Istoku, te jedna od najvećih emotivnih trauma koju je Fallaci u kasnim četrdesetima doživjela, gubitak, odnosno ubojstvo, partnera s kojim je živjela, poznatog grčkog revolucionara i pristaše grčkog Pokreta otpora ${ }^{234}$, Alexandrosa (Alekosa) Panagulisa, u svibnju 1976. godine, autoricu su odvojili od njezine novinarske struke i pisanja kontroverznih članaka, te nanovo i zauvijek približili literarnom stvaralaštvu. Nakon duge bolesti i gubitka majke, tragičnog i iznenadnog gubitka životnog suputnika, te službene ostavke u redakciji Europea, Fallaci se povlači u ladanjsku obiteljsku kuću u Grevi in Chianti, u Toscani, gdje se tri i pol godine u potpunosti i isključivo posvećuje pisanju romana Un uomo (Jedan čovjek), romanu o životu i smrti jedinog muškarca s kojim je dijelila apsolutno sve (Aricò 1998, p. 177-178).

Teško je reći, ni sama Fallaci to ne uspijeva odrediti, kada počinje ova dramatična životna priča, u kojemu trenutku su se sudbine dviju karizmatičnih povijesnih ličnosti ispreplele. 13. kolovoza, 1968. godine, dok je Panagulis pripremao atentat na vođu diktatorskog režima u Ateni, Georgiosa Papadopoulusa, Fallaci je posvećena vijetnamskoj tragediji. 17. studenog iste godine, dok je on, išćekujući egzekuciju, boravio u zatvorskoj ćeliji, trpeći zvjerska zlostavljanja, ona se oporavljala od oružanog napada u jednoj meksičkoj bolnici. No, iako geografski još uvijek udaljeni, njihove se životne priče već tada jasno prepliću, vodeći ih u smjeru konačnog susreta.

Nakon neuspjelog atentata na Papadopoulusa, Alekosa uhićuju i više od dva mjeseca muče i zlostavljaju, ne bi li progovorio o mogućim pomagačima demokratskih režima u inozemstvu, od kojih su grčke vlasti najviše strepile. No, on odbija govoriti, odbija i potpisivanje priznanja koje mu nude u zamjenu za slobodu. Odbija razgovor i konsenzus s predstavnicima režima, odlučno im se suprotstavljajući vlastitim fizičkim, psihičkim i moralnim, nadljudskim, naporima.

${ }^{234}$ Grčki Pokret otpora nastao je kao reakcija na diktaturu grčkih pukovnika, sinonim za totalitarni režim oformljen 21. 04. 1967. godine u Ateni. Inspirirana talijanskim fašizmom, diktatura je trajala sve do 24. 07. 1974. godine, kada ju je parlament službeno ukinuo. U tom sedmogodišnjem razdoblju Grčka je vođena nizom manjih antikomunističkih vojnih grupacija, na čelu kojih su se nalazili pukovnici, Georgios Papadopoulos, Nikolaos Makarezos te Ioannis Ladas, koji su se vlasti domogli iznenadnim državnim udarom kojim je ugušena parlamentarna demokracija, a demokratski izabrana koalicija lijevog bloka i bloka desnoga centra protjerana je. Nakon nasilnog preuzimanja vlasti uslijedila su protjerivanja, deportacije, uhićenja, pa čak i naručena ubojstva onih koji su se usudili suprotstaviti. Civilne i političke slobode u razdoblju vladavine pukovnika uništene su, a kraljevska je obitelj prognana iz zemlje. 
Štrajka glađu, tjednima ne spava, samoozljeđuje se i krvlju sastavlja stihove, a nakon višestrukih tjelesnih ozljeda, svoj lik u ogledalu više ne prepoznaje. Osuđen na smrt, taj u grčkom narodu nikad prežaljeni heroj, tri dana i tri noći provodi čekajući trenutak konačne egzekucije, koja se neprestance odgađa, produbljujući agoniju i osjećaj bespomoćnosti pred toliko puta zazivanom smrću. U međuvremenu, interes javnosti za njegovu sudbinu iz dana $u$ dan raste, prelazeći granice Grčke, što vlast obeshrabruje i čini neodlučnom u namjeri da odluku o smaknuću konačno i sprovede. Naposljetku, smrtna kazna biva poništena, a Alekosa premještaju u okrutnu, sićušnu i mračnu tamnicu, sagrađenu isključivo za svrhu i namjenu jednog političkog zatvorenika. U tom „hladnom i mračnom grobu, tri metra puta dva“ (De Stefano 2015, p. 201) Panagulis provodi punih pet godina.

19. kolovoza 1973., zbog prevelikog pritiska javnosti i medija, grčke vlasti oslobađaju Panagulisa, a samo par dana nakon toga, 23. kolovoza, dogodit će se njegov sudbonosan susret s kontroverznom talijanskom novinarkom o kojoj svi govore i pišu (De Stefano 2015, pp. 197; 201). Ona očekuje otvoren i vrlo intiman razgovor, znajući da pred njom stoji muškarac naoružan izuzetnom moralnom hrabrošću, zahvaljujući kojoj, usprkos najokrutnijim zlostavljanjima, nije progovorio o sebi (Rosa 1982, p. 58). De Stefano (2015, p. 198-199) ističe kako je Fallaci već od prvoga susreta ostala očarana prisustvom svih onih duhovnih $\mathrm{i}$ moralnih vrijednosti koje je ovaj nacionalni heroj posjedovao, a u koje je i sama oduvijek vjerovala: „tjelesna i moralna hrabrost, opsjednutost konceptom slobode, borba protiv struktura moći“ (p. 198). On utjelovljuje sve ono što njezino djetinjstvo i mladenačke godine predstavljaju, talijanski Pokret otpora, borba za jednakost i sredinu dostojnu ljudskog bića te žudnja za slobodom od svih totalitarnih i represivnih sustava moći koji propagiraju hegemoniju i jednoumlje:

\footnotetext{
U njemu vidjeh mnoga od onih stvorenja što ih upoznah putujući po svijetu, stvorenja koja su podmetnula vlastiti život za viši cilj, cilj zbog kojeg bijahu mučeni, zatvarani, često i usmrćeni. (Fallaci u: De Stefano 2015, p. 199)
}

On joj u potpunosti vjeruje, osjeća da je ona tu, samo zbog njega, te joj se bez imalo zadrške predaje. Govori joj o svojoj prošlosti, sadašnjosti i utopijskim očekivanjima u zemlji obavijenoj korupcijom, političkim terorom i tiranijom. Razgovor završava u kasnim noćnim satima, kada ujedno započinje ljubavna veza dvoje ljudi zadivljenih i opsjednutih pojmom sloboda. 
Po svemu sudeći, odnos Fallaci i Panagulisa bio je antagonistički odnos slobodne i emancipirane zapadne žene u potpunosti posvećene vlastitoj karijeri i tradicionalnog grčkog muškarca predanog politici i umjetnosti, ${ }^{235}$ koji usprkos svim njezinim nastojanjima da se zajedničkim snagama izbore za sigurniji i spokojniji život, daleko od nemira i očiju javnosti, nije uspio odoliti zovu političke revolucije, svjesno srljajući u smrt. Nakon gotovo četiri burne godine zajedničkog života, perioda u kojem ona gubi još jednu trudnoću, Alekos stradava u insceniranoj automobilskoj nesreći. Grčki je narod na koljenima, više od milijun ljudi preplavilo je ulice Atene. Okupljeni oko Panagulisovog lijesa zazivaju Orianino ime, moleći je da o njemu piše, da ga ne zaboravi (Fallaci 1979b, p. 12-17). Tako nastaje roman Un uomo.

Literarno-novinarski pastiš, reportažni dnevnik na tankoj granici fikcije i političke istine, biografski roman Un uomo, demonstrirajući još jednom autoričin izražen afinitet prema antiinstitucionalnoj nomadskoj estetici, predstavlja se kao spojnica biografije i autobiografije, literarnog i antiliterarnog, političke optužnice i romansiranog tragičnog mita s elementima folklora. ${ }^{236}$ Umećući tehnike književnog realizma, te kombinirajući ih s onima špijunskog trilera i klasične tragedije, u tragičnu dokumentarističku reportažu autorica vrlo uspješno uspijeva ugraditi vlastita iskustva, razmišljanja, filozofske i političke stavove, ,pritom ne kompromitirajući sadržaj“ (Aricò 1998, p. 187).

Tematski, roman obuhvaća tri povijesne istine, o kojima autorica, u obliku sjećanja, progovara. Prva je ona o životu i smrti grčkoga junaka i njegovoj borbi za slobodu, druga je ona o kvarnosti i prijetvornosti političkog režima, o truležu koji izjeda temelje zapadne demokracije, a treća, no istodobno možda ipak prva, jest ona o zajedničkom životu dvoje ljudi osuđenih na glad za pravdom i moralnim društvom. Upravo su ovakva sadržajna slojevitost i osjetljivost biografskih, ali i političkih, podataka, te javna objava materijalnih dokaza o nikad procesuiranom političkom deliktu, kao i opće društvena klima mediteranskog područja sedamdesetih, zaslužne za ovakav opsežan i mnogostruk žanrovski eksperiment.

\footnotetext{
235 Alekos Panagulis, kako je nebrojeno puta i sama Fallaci isticala, bio je pjesnik i umjetnik. Uz Fallacinu

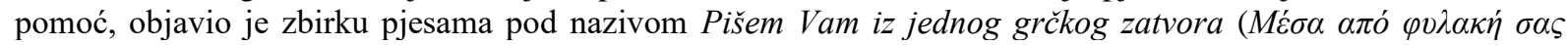
$\gamma \rho \alpha ́ \varphi \omega \sigma \tau \eta v E \lambda \lambda \alpha \dot{\alpha} \delta \alpha, 1974$.), zbirku koja sabire pjesme napisane u razdoblju Panagulisovog pritvora, od 1968. do 1973. godine. Pjesme, najčešće vrlo kratke, pisane još češće samo u obliku anafore, zrcale patnju političkih zatvorenika u doba diktature i totalitarnog režima grčkih pukovnika. Neke je pjesme 1980. Ennio Morricone i uglazbio. Talijanski su prijevod uredili Oriana Fallaci i Pier Paolo Pasolini, koji je ujedno napisao i predgovor, a objavila ga je kuća Rizzoli iz Milana.

${ }^{236}$ Roman posjeduje strukturu narodne priče i grčkoga mita. Junak započinje svoju bitku s nepobjedivim strukturama moći, potom slijedi razdoblje iskušenja, zatim povratak, pa kraj, najčešće kao smrt ili apoteoza.
} 
Naime, nakon 1968., pa sve do konca sedamdesetih, Mediteran je doživljavao teško razdoblje političkog preporoda. Teroristički napadi, politička ubojstva i širenje mafije, kao odgovor na jačanje ekstremne desnice, obilježavali su svakodnevicu mediteranskog područja. U vrijeme u kojem je Fallaci živjela i pisala na istodobno tri lokacije, u New Yorku, Firenci i Ateni, u njezinoj rodnoj Italiji, počevši od godine 1969., dogodio se niz atentata i organiziranih ubojstava poznatih političara i ljudi iz kulture, među kojima su široj svjetskoj javnosti najpoznatija ubojstva Pier Paola Pasolinija 1975., te vođe kršćanskih demokrata Alda Mora 1978. Obzirom na delikatnu političku situaciju, kako u Italiji, tako i u Grčkoj, iako odlučna u namjeri da javno progovori o istini tragične sudbine čovjeka kojeg je voljela, Fallaci se odlučuje na optužnicu javnim zazivanjem nužnosti sudskog procesa u obliku proznog književnog teksta. Pripovjedačkim tehnikama, kojima apsolutno dominiraju i upravljaju prodornost i putenost ženskog i ženstvenog, autorica pretvara biografsku istinu u književnu maštu kojom odjekuje obraćanje ženskog glasa preminulom ljubavniku. Rekonstruirajući događaje koji su potakli, u konačnici i doveli, do ubojstva Alekosa Panagulisa, pomno istražujući materijalne dokaze o teškoj korupciji grčke vlade, koje je Alekos prikupljao, svako pojedino poglavlje umata u ritam književnog jezika i govornog glasa. Andrews (1980) ističe kako je Fallacin roman u suštini detaljna rekonstrukcija i osuda očito planiranog političkog ubojstva, koje nikad nije podleglo pravednom sudskom procesu i adekvatnim sankcijama, kako od strane grčke sudbene vlasti, tako i od strane međunarodnih institucija. Fallacin J'accuse, umotan u subjektivno i literarno, odgovor je na neispunjenu moralnu i političku odgovornost, na subordiniranost i korupciju izvršne i sudbene vlasti. Kako jezikom političke revolucije, kakvim je govorio Alekos Panagulis, nije bilo moguće pisati, odnosno obzirom na činjenicu da je sudski proces u potpunosti podbacio, javni apel narodu mora pronaći alternativan put, mora otići do širokih masa, mora probiti granice domovine, mora biti dostupan svim slojevima čitateljske publike. Univerzalni simbol tragičnog junaka i njegova romantizirana borba prodani su tako u više od 1800000 primjeraka samo u Italiji unutar dvije godine, te prevedeni na više od trideset jezika (Rosa 1982, p. 79).

Tijekom trogodišnjeg pisanja i posvećenosti ovom zahtjevnom literarnom projektu, Fallaci je sadržaj i oblik romana više puta izmijenila. Uvodni dio i predgovor pisani su u kasnijoj fazi, a prva je verzija djela bila čak tristo stranica dulja od konačne (Aricò 1998, p. 179). Kreativna tekstualna strategija, kakvu je njegovala Oriana Fallaci, a koja se gotovo uvijek sastojala od neprekidnih revidiranja, dekonstruiranja i rekonstruiranja, rezanja i umetanja, 
jasno podsjeća na tezu Sandre M. Gilbert i Susan Gubar (1979) o tzv. ženskoj kreativnoj shizofreniji, kojom ove autorice označavaju nov, jedinstven i karakteristično ženstven način pisanja, specifičnu i izuzetno sofisticiranu tekstualnu taktiku. Ta kreativna kaotičnost, fragmentiranost i „ludilo“ (p. 80), o kojima Gilbert i Gubar pišu, sinonimi su tako ženske i ženstvene estetske perspektive, odnosno odraz autoričinih podvojenih podsvjesnih mehanizama zbog kojih monolitan i cjelovit način pisanja biva odbačen, a prihvaćena jedna alternativna, gotovo tjelesna, kreativna psihodinamika.

Možda je upravo ovakvo odbacivanje uobičajenih i dominatnih trendova pisanja omogućilo Fallaci da vlastitim glasom, u obliku bolnog sjećanja, prenese poruke voljenog muškarca, jer roman Un uomo sastoji se upravo od dvostruke i dvolične autorske strategije, namjere da vlastitim glasom oblikuje misli glavnoga lika. Osnovno sadržajno gradivno tkivo teksta temelji se u potpunosti na dokumentiranim činjenicama i bilješkama koje je autorica o Panagulisu, za vrijeme i nakon njegova života, vodila, na način da su njegove riječi i njegov glas kao prvo utočište pronašli u Fallacinim mislima i osjećajima, da bi potom, u obliku sjećanja, iz oblika povijesno-političkog dnevnika prešli u autobiografsku fikciju:

\footnotetext{
Sjećam se vrlo dobro svih stvari o kojima je govorio, načina na koji je izražavao svoja politička uvjerenja. Moja su sjećanja bila još svježa kada sam započela pisati knjigu... (Fallaci u: Aricò 1998, p. 179)
}

Spinazzola (1979) ističe kako je upravo ovakva tekstualna strategija, koja podrazumijeva filtriranje i revidiranje poruka i misli glavnoga lika, Alekosa Panagulisa, omogućila autorici da toliko puta zazivano $T i$ postane zapravo $J a$, da vokalno nadvlada tekstualno, da literarno preoblikuje političko, da žensko i ženstveno preuzmu, interpretiraju i potom javno objave muško i muževno. Na ovaj način, nadovezuje se Rosa (1982, p. 77-80), Panagulisova biografija postaje zapravo samo jedno poglavlje unutar Fallacine autobiografije.

Roman Un uomo predstavlja se tako, u terminima analitičke psihologije, kao dvostruka projekcija imaga, nesvjesnog arhetipskog otiska, muškarca u ženi, odnosno žene unutar teksta. I čini se da upravo taj dijalektički proces autonomnih kontraseksualnih silnica omogućuje autorici prihvaćanje i potpunu integraciju vlastitih unutarnjih konflikata, te prekid procesa žalovanja. 
Fallaci se u djelu prikazuje kao Panagulisov duhovni mentor, njezina životna iskustva gotovo da preplavljuju ona glavnoga lika. Njezin upečatljiv govorni otisak, količina osobnih podataka koje u tekstu podastire, u velikom dijelu zasjenjuju Panagulisovu tragediju, a Santo Aricò (1998, p. 187) mišljenja je da je roman sasvim legitimno mogao biti naslovljen Jedna žena. Tu pomalo prikrivenu i samozatajnu autobiografsku tendenciju u možda najvećoj mjeri osnažuje obraćanje autorice u drugom licu jednine preminuloj ljubavi. ${ }^{237} \mathrm{U}$ tom, po svemu sudeći, jednostranom dijalogu, ${ }^{238}$ sama tehnika apostrofiranja, ne više živućeg bića, omogućuje autorici da objasni sebe i vlastite osjećaje: „Ne koristim vlastito ime u knjizi, no koristim riječ $T i$ kako bih zapravo opisala vlastite osjećaje“ (Fallaci u: Aricò 1998, p. 178). No, analizirajući ukupnu narativnu strategiju i dijalošku dinamiku romana u cjelini, postaje očito da tijekom pripovijedanja, kako se roman polako proteže prema kraju, adresat ovog dijaloga nije uvijek konstantan. I dok na samome početku romana autorica odlučuje isključivo komunicirati s preminulim ljubavnikom,

Eto, Ti, moj jedini mogući sugovorniče, dolje u podzemlju, dok sat bez kazaljki označava put sjećanja. (Fallaci 1979b, p. 18)

ipak, čini se da od ove odluke vrlo brzo odustaje, jer već u prvome poglavlju drugoga dijela adresat postaje čitatelj:

I ovo je bio muškarac kojeg bih sutradan konačno susrela, zalijećući se u njega poput vlaka koji vozi u suprotnom smjeru istom prugom. (p. 151)

U tom smislu, sama narativna formula djela postaje, na neki način, podvojena, odnosno „dvonalična“ (Gilbert i Gubar 1979). U genetteovskim terminima, njezino je sebstvo, autorsko $J a$, rascijepljeno u dva dijela: ekstradijegetska istanca autora-pripovjedača po imenu

\footnotetext{
${ }^{237}$ Jacques Derrida (1986, pp. 23-24; 26) govori o tzv. tanatografiji, glasu koji odjekuje iz groba, glasu onoga kojeg autor osluškuje. Prema njegovom mišljenju, autobiografija jest sama po sebi pisanje o onima kojih više nema, u suradnji s onima kojih više nema. Ona uvijek označava odsutnost osobe o kojoj se govori. Slično tvrdi i Jacques Lacan (1983b) koji ističe kako istinska prisutnost subjekta u govoru u naravi ne postoji. Ona je, na neki način, uvijek uvjetovana njegovom djelomičnom odsutnošću. Ne postoji jezični sustav, zaključuje Lacan, koji posjeduje sposobnost obuhvaćanja cjelokupnog ontološkog bića u trenutku. I Paul de Man (1984) objašnjava kako autobiografski subjekt ne predstavlja identitet već retorički konstrukt koji se ustanovljuje isključivo procesom čitanja, trenutkom u kojem subjekt teksta i subjekt čitanja neprestance zamjenjuju svoja mjesta.
}

${ }^{238}$ Podsjeća na Fallacin roman Pismo nerođenu djetetu (1975b). 
la Fallaci, poznata spisateljica, te intradijegetska instanca imenom Oriana, koja se tekstom kreće i dio je priče o tragičnom junaku (Genette 1980).

Naratološka metodologija dodatno se komplicira reprodukcijom Panagulisovih izjava koje, jedna po jedna, prolaze imaginarijem ženskog i ženstvenog:

\begin{abstract}
Naravno da prihvaćam optužnicu. Nisam je nikada odbijao. Ni tijekom ispitivanja, ni pred vama [ ... ] Bijah uvijek, i jesam, borac za jednu bolju Grčku, jedno bolje sutra, jedno društvo koje vjeruje u Čovjeka. Ako se nalazim ovdje, onda je to zato jer vjerujem u Čovjeka. Vjerovati u Čovjeka znači vjerovati u njegovu slobodu. Slobodu misli, riječi, kritičkog promišljanja, suprotnosti... (Fallaci 1979b, p. 61-62)
\end{abstract}

U naravi, karakterizacija glavnoga lika događa se većinom putem Njegovih izjava, kojima se On otkriva, razvija i pozicionira unutar teksta, dok ga Ona, na neki način, podržava i prati, potvrđujući istinitost i ozbiljnost cjelokupnog političkog procesa. Riječi koje je Panagulis izgovorio ostale su duboko urezane u Fallacinu sjećanju i ona ih sada vraća njemu, kako bi mu pomogla da prekine dugogodišnju šutnju.

S teorijskog aspekta ostaje i dalje vrlo diskutabilno koliko uistinu ovakva intimna artikulacija osobnih, vlastitih i drugih bliskih, podataka može biti ostvarena i vjerodostojno iskazana unutar tekstualnog, osobito unutar teksta koji pretendira biti literaran. Naime, sa žanrovskog stanovišta, sam je tekst, kako to najčešće i biva, iz oblika dnevničkih zabilješki prerastao u biografsko, odnosno autobiografsko literarno djelo, odnosno literarnim je postupcima, dopunama i izmjenama pretočeno u svojevrsno naknadno svjedočanstvo obilježeno snažnim autobiografskim imprintingom, koje noseći tragove autorskog $J a$ postaje sve više osobno, subjektivno i pristrano.

Predrag Finci (2011, p. 22) tvrdi kako profesija i vokacija najčešće usmjeravaju pisanje te ujedno i uvjetuju stav koji će pisac zauzeti u odnosu na događaj koji opisuje. Prema njegovom mišljenju, svaki intimniji tekst, dnevnik, ispovijest, biografija ili autobiografija, proizlazi iz osobnog, prerađenog i personaliziranog, doživljaja. Uzimajući u obzir činjenicu da je Oriana Fallaci bila prvenstveno novinar i ratni izvjestitelj, s uvijek vrlo jasno izraženim osobnim političkim i ideološkim stavovima, za očekivati je kako će opisani događaji i cjelokupan Panagulisov proces, kao i sama karakterizacija njegove duhovne i materijalne osobnosti, biti u velikom dijelu natopljena autoričinim psihičkim sadržajem. Genette (1987, pp. 363; 370) ističe kako je dnevnik oblik intimnog svjedočanstva koji, u ulozi parateksta osnovne poruke 
ili uvjerenja, teži da se, prije ili kasnije, pridruži svom tekstu, odnosno da u konačnici postane knjiga. Kako u tom procesu intimno bilježenje autorovih, autoričinih, iskustava postaje zapravo svjedočanstvo izloženo pozornosti drugih aktera, ${ }^{239}$ autoričino se intimno Ja (Oriana) ogoljuje i izlaže širokoj masi te postaje neposredno i javno dostupno (la Fallaci), što u konačnici upućuje na agilne stilske vještine pripovijedanja, no istovremeno i na udaljavanje od mogućnosti istinski pouzdanog svjedočenja. ${ }^{240} \mathrm{U}$ tom smislu, roman Un uomo, usprkos svim početnim ambicijama da postane dnevnik jedne političke ere, poprima zapravo sve karakteristike tzv. écriture de soi, ${ }^{241}$ odnosno osobnih autoričinih memoara. Razmatrajući psihološki i psihoanalitički aspekt Fallacinog krojenja romana, očito je da se inicijalno topografsko težište, objavljeno u samom naslovu, s Njega preselilo na Nju. U lacanovskim terminima, pisanje nije više dokaz vremena već prostor žudnje za Drugim (Autre), žudnje za drugom osobom kojoj se autorica ima potrebu obraćati, kako bi uspostavila raskinute veze vlastitog $J a$ i publike koju na samome početku romana osuđuje (Fallaci 1979b, p. 12-16). Ona tako postaje zrcalo samoj sebi, ${ }^{242}$ postaje u isto vrijeme ona koja ispovijeda $\mathrm{i}$ ona koja razrješuje, ona koja pripovijeda i ona koja aktivno sudjeluje, ona koja istinu transformira $u$ ethos (Foucault, 1994), suočavajući se istovremeno s vlastitim sebstvom, s vlastitom ženskošću i ženstvenošću, s vlastitom istančanom i naglašenom osjetilnošću. ${ }^{243}$

Najvjerojatnije, iznenadna smrt životnog suputnika djelomično je izuzela autoričinu mogućnost objektivnijeg sagledavanja stvarnosti i činjenica, tako da se iz oblika metafizičkog, općefilozofskog diskursa, kakav je posjedovao prvi dnevnički zapis (Aricò 1998, p. 179), ubrzo prelazi u subjektivnu autobiografsku ispovijest, putem koje se promišljanja o političkim

\footnotetext{
${ }^{239}$ Postaje interaktivni prostor interpretativne kooperativnosti čitateljske publike.

240 Derrida (1986) iskazuje određeno nepovjerenje u autobiografiju, razmatrajući kontekst performativnosti autobiografskog žanra $\mathrm{i}$ nemogućnosti autora da $\mathrm{u}$ istome trenutku zadovolji tehnički aspekt osobnog portretiranja i ostane vjeran istini.

${ }^{241}$ Pisanje o sebi (Foucault, 1994).

${ }^{242}$ Michael Beaujour (1980) ističe kako autobiografija ne bi smjela biti sagledana kao autoportret osobe koja opisuje, već kao zrcalo unutar kojeg se njegovo sebstvo reflektira i umnožava. Ona predstavlja nikad završen proces lingvističke semioze.

243 Derrida (1988) uvodi termin otobiografija, objašnjavajući kako u autobiografskom tekstu pisac ujedno izgovara, ali i sluša, izgovoreni tekst (p. 13). Na taj način, tekst omogućava komunikaciju sa samim sobom. I Freud (2001b), analizirajući komunikaciju analitičara i pacijenta, primjećuje da se prilikom iznošenja činjenica, prepričavanja snova, subjekt služi takvim diskurzivnim metodama, kako bi naposljetku sam sebi postao objekt te kako bi stvorio određene preduvjete za subjektivnije i pristranije portretiranje samoga sebe. Upravo iz tog razloga, ističe Freud, sam sadržaj biografije postaje manje bitan, a na većoj važnosti dobivaju motivacija i intratekstualni prazni prostori.
} 
i povijesnim događajima pretvaraju u jasno određene političke stavove i opredjeljenja. Sama tehnika teksta, zajedno s okolnostima njegova nastanka, ustupaju tako onaj prvotni i najznamenitiji značaj osobnom autoričinom pečatu, tako da se događaji vezani uz Panagulisovu tragediju prepliću s autoričinim tokom svijesti, a djelo zamišljeno kao biografski roman-dnevnik postaje Fallacina autobiografija. To ujedno doprinosi prevladavanju estetskog u odnosu na sadržajno, zbog čega je Fallacin vokalni otisak nadjačao Panagulisovu priču, a umjetnička rekonstrukcija kao da postepeno lišava tekst osobitog značaja tematske okosnice. Takvo prevladavanje i nadvladavanje estetskih svojstava omogućeno je, prvenstveno, radi protoka vremena, odnosno vremenskog odmaka od proživljenih iskustava, koje se sada naknadno, u obliku sjećanja, vraćaju. No, ovaj put prolazeći, autorskim perom Oriane Fallaci, proces selekcije, revidiranja i rekonstruiranja, dovodeći tako u prvi plan autoričin osobni stil i glas.

U raspravi o autobiografiji Georges Gusdorf (1991, p. 10) objašnjava kako Auto predstavlja autonomnu egzistenciju, identitet, autora autobiografije, Bio egzistencijalni kontinuitet onoga što Auto čini, a Graphie obilježava proces rekonstrukcije vlastitog bića. Također, ističe i kako između Auto i Bio, između ontološkog bića i njegove egzistencije, između identiteta i životnog iskustva, uvijek postoje određene pukotine i fragmentarnosti (inaccomplissement), a sve se dodatno komplicira činom pisanja, Graphie, jer se upravo u tom trenutku stvara, na neki način, dvostruko sebstvo, ${ }^{244}$ ono koje piše i ono o kojem se piše. Prema mišljenju Gusdorfa (p. 124), cjelokupan autobiografski proces nije u suštini istina o životu, već samo jedna utopija onog što bi život mogao biti ili predstavljati, jer čak i u trenutku dok iskustva bivaju bilježena, u trenutku u kojem se autor i pripovjedač obraćaju, život zadržava svoje fluidno, fluktuirajuće svojstvo i neprekidno se mijenja i pokreće, tako da je autoru gotovo nemoguće obuhvatiti jednu cjelovitu i nepromjenjivu istinu, što Gusdorf označava kao autobiografsku nostalgiju, jer kako i analitička psihologija objašnjava, u ljudskoj je prirodi težiti ka duševnoj i psihičkoj cjelovitosti, ka ispunjenju i utjelovljenju vlastitog Sebstva ${ }^{245}$.

Uzimajući u obzir sve okolnosti nastanka Fallacinog romana, njezinu blisku emotivnu vezu s glavnim likom, čiji život i smrt opisuje, no istodobno razmatrajući formalne aspekte djela, kao i autoričin neupitan ideološki angažman, uistinu je teško ustvrditi žanrovsku granicu

\footnotetext{
${ }^{244}$ Teorija podsjeća na termin répéperage en soi Hélène Cixous (1975b) koja govori o dvostrukoj lokaciji sebstva, o biseksualnim karakteristikama tekstova u ženskom autorstvu (p. 254).

${ }^{245}$ Selbst (Jung 1977d, p. 189).
} 
povijesno-dokumentarističkog i fikcije, biografskog i autobiografskog. U tom smislu, roman Un иото, inicijalno zamišljen kao biografski dnevnik marginaliziranog i obespravljenog nacionalnog heroja i totalitarnog režima koji guši svaki pokušaj pojedinca za uspostavom slobodne demokracije, prerastao je u autobiografsko svjedočanstvo jedne politike i ideologije s elementima mimesisa, ${ }^{246}$ kako bi se stvorili preduvjeti za konačno obračunavanje s prošlošću. S epifenomenološkog aspekta, Fallacin je roman na tankoj granici povijesnog dokumenta, autentične (auto)biografije i fikcije, na granici historiografskog, romanesknog i nečeg posve intimnog.

No, zašto je Fallaci upravo kroz Panagulisovu patnju i smrt odlučila, a u tome očito i uspjela, zaokružiti jednu epohu, jedno životno razdoblje? Naime, u psihoanalitičkom smislu, autobiografsko pisanje podrazumijeva izuzetno zahtjevno i mukotrpno, najčešće nedovršeno i neispunjeno putovanje u samog sebe. Dok život traje, stvaranje uvijek ostaje jednim dijelom neispunjeno, stvaralačka žudnja neutažena, a sam čin apsolutnog postignuća onemogućen. Jedino smrt proces stvaranja u potpunosti zatvara, približavajući ga, na taj način, savršenstvu koje se više ne dovodi u pitanje. Također, u klasičnom opisivanju sebe nije moguće u potpunosti isključiti sebe. Klasična autobiografija, na neki način, omeđuje i ograničava njezinog autora samim sobom. On/ona, kao pisac i stvaralac, naprosto ostaje ograničen činjenicama koje omeđuju i obilježavaju, čine istinitim i uvjerljivim, njegov iskaz. No, u ovako neobičnoj artističkoj kombinaciji biografskog i autobiografskog, kakav je roman $U n$ uomo, lingvističkom travestijom autorice u lik i pripovjedača, ona postaje slobodna da govori i čini van konteksta provjerenog, pouzdanog i jedinog legitimnog. Na taj način, iako roman jest priča o jednom muškarcu i njegovim patnjama, ipak ta priča ostaje izbodena kodovima ženskog i ženstvenog.

Fallaci tako odustaje od klasičnog modela (auto)biografije, priklanjajući se alternativnom i subverzivnom načinu biografskog pripovijedanja. Filtrira i oduzima fragmente povijesti, umećući osobno i intimno, pružajući mogućnost samome tekstu u nastanku da stvara jedan potpuno nov entitet onog koji inicijalno progovara, da ga, na neki način, podvoji. Autorica postaje tako produkt teksta, produkt performativnih retoričkih tekstualnih strategija. ${ }^{247}$

\footnotetext{
${ }^{246} \mathrm{U}$ smislu naknadne rekonstrukcije proživljenih iskustava.

${ }^{247}$ „Autobiografija je priča o jednom, putem teksta, ponovno nađenom $J a^{\text {“ }}$ (Finci 2011, p. 119).
} 
Vraćajući se na Gusdorfove teze o ulozi Auto, Bio i Graphie, unutar pojma autobiografija, potvrđuju se njegovi navodi o ulozi čina pisanja (Graphie), u odnosu na subjekt (Auto) i njegovo iskustvo (Bio), jer upravo sam čin pisanja omogućava autoru rekonstrukciju vlastitog sebe. Također, narativne strategije, kojima pribjegava Oriana Fallaci, upućuju na teoriju Christine Battersby (1989) i Adriane Cavarero (1997) o ženskim biografijama i autobiografijama kao dugotrajnim i slojevitim procesima analize i cjepkanja segmenata životnih iskustava, kojima se tek unutar teksta ostvaruju određene semiotičke i hermeneutičke mogućnosti. U tom smislu, kao da je autorica, odvajajući jedan dio sebe koji je proživio s Panagulisom njegova iskustva, od onog drugog dijela tog dvostrukog sebstva, dijela koji piše i predstavlja se kao Autor, kako bi, s jedne strane, omogućila Alekosu da kroz nju progovori, a s druge, da samu sebe jasno odredi i pozicionira, prilika koju izvan teksta nije imala, te na taj način zatvori i zauvijek zapečati jedno bolno poglavlje života. 


\section{II. III. Lingvistička deteritorijalizacija}

Smrt Alekosa Panagulisa, kao i sve društvene i političke okolnosti vezane uz njegovu tragičnu sudbinu, udaljile su Fallaci od novinarske karijere, od bliskih kontakata s kolegama i suradnicima, od interesa za tada goruća svjetska pitanja. Ipak, nakon tri pune godine potpune izolacije te isključive posvećenosti pisanju romana Un uomo, po konačnom završetku tog zahtjevnog literarnog projekta, autorica malo po malo uspostavlja vezu s vanjskim svijetom. Nakon kraće serije kontroverznih intervjua s tada ključnim osobama svjetske političke scene, među kojima se najviše pamte onaj s Khomeinijem u rujnu 1979., Muammarom Gaddafijem u prosincu iste godine, te Dengom Xiaopingom u kolovozu 1980., njezin interes i pažnju u potpunosti pobuđuju novonastale okolnosti na Bliskom Istoku. I dok je vijetnamska rana tek započela cijeliti, ona libanonska tek se otvara i privlači interes šire svjetske javnosti. ${ }^{248}$ Zatečena i uznemirena medijskim informacijama o vrlo odlučnoj i agresivnoj invaziji izraelske vojske na libanonski teritorij u lipnju 1982. godine, Fallaci napušta europski kontinent i samostalno se upušta u još jednu ratnu avanturu. ${ }^{249}$ Po dolasku u Beirut stupa u direktan kontakt s generalom Arielom Sharonom, a potom odlazi u posjet talijanskom kontingentu, po detaljne informacije o budućim vojnim operacijama. Bilježi, kao i uvijek, izravna svjedočanstva vojnika i civila u najugroženijim područjima. Osobito ostaje potresena događajem iz listopada 1983. kada dva islamska vojna vozila raznose američke i francuske

\footnotetext{
${ }^{248}$ Libanonski sukob, u izraelskom narodu poznat pod imenom Operacija Mir za Galileju, multietnički i multireligijski je sukob službeno započet 6. lipnja 1982. godine izraelskom invazijom na Južni Libanon kako bi iz njega protjerao palestinske militante, pripadnike PLO (Palestinske Oslobodilačke Organizacije). Casus belli, međutim, seže u razdoblje samog početka arapsko-izraelskog sukoba, u godinu 1948., kada je preko 110000 palestinskih izbjeglica, u potrazi na novom domovinom, iz Izraela pobjeglo u Libanon. Nasilno naseljavanje Palestinaca u tri najznačajnija beirutska šijitska predgrađa, Sabru, Chatilu te Bourji el Barajni, kao i neke manje dijelove grada u kojima su obitavali kršćani, uzrokovalo je snažan otpor lokalnog stanovništva, bijes Izraelaca, ali i početak beskonačnog etničkog i vjerskog sukoba koji je na jednoj strani imao militante PLO-a, sirijsku vojsku, Al Fatah i tada tek osnovani Hezbollah, a na onoj drugoj kršćanske skupine, falangiste i izraelsku vojsku (Fallaci 1990, p. 43). Fallaci opisuje kako su pripadnici palestinskih militantnih skupina iz dana u dan jačali i širili se libanonskim teritorijem, sve do potpune eskalacije sukoba godine 1964., kada su uz pomoć zemalja članica Arapske lige izvršili masovni teroristički napad (p. 43-45). Prema mišljenju autorice, ovo će biti klica svih budućih muslimanskih terorističkih napada koji će u narednom stoljeću uslijediti diljem svijeta (p. 119). 1976. u sukob se uključuje Sirija, 1978. pripadnici Al Fataha i Hezbollaha, kada je u terorističkom napadu na izraelskoj plaži ubijeno 35 civila, 4. lipnja 1982. godine Izrael službeno objavljuje početak sukoba bombardiranjem palestinskih izbjegličkih kampova u Južnom Libanonu i Beirutu, a 6. lipnja iste godine general Ariel Sharon započinje invaziju Libanona, odnosno potpuno uništenje njegovog glavnog grada. Opsada Beiruta i zračna bombardiranja trajala su punih 10 tjedana. Ubijeni su pripadnici PLO-a, ali i mnogi civili, više od 17800 Arapa izgubilo je živote. Usprkos brojnim vojnim intervencijama SAD-a, Francuske, Velike Britanije i Italije, koje su u jednogodišnjoj međunarodnoj misiji poslale više od 4000 vojnika, sukob se spontano okončao tek 2000. godine, kada se izraelska vojska u potpunosti povukla iz libanonskog područja, a PLO nestao.
}

${ }^{249}$ Fallacin dugogodišnji kolega i prijatelj, talijanski novinar i urednik Umberto Cecchi, prisjeća se njihovog susreta na aerodromu u Pisi, dok je čekala ukrcaj za Beirut (Cecchi 2013, p. 181). 
vojne baze, ubijajući u snu više od četiristo vojnika (Fallaci 1990, p. 15-35). Aricò (1998, p. 201) ističe kako je upravo ovaj događaj autoricu izravno potakao na pisanje novog ratnog romana, u čast „svim muškarcima, ženama, starcima i djeci ubijenih u drugim masakrima toga grada i u svim masakrima onog beskrajnog masakra po imenu rat“ (Fallaci 1990, p. 5). Samo 72 sata nakon atentata na međunarodne trupe, Fallaci odlazi u Ministarstvo obrane u Rimu po dozvolu za boravak u Beirutu, osjećajući pritisak upravo začetog zametka (p. 39) onog što će ubrzo postati njezino najistaknutije literarno postignuće, ${ }^{250}$ opsežni ratni roman Insciallah.

Libanonski literarni projekt Insciallah, jedan od još uvijek vrlo rijetkih ratnih romana ikad napisanih ženskom rukom, najkompleksnije je Fallacino djelo. Toj „,malenoj Ilijadi“ (p. 160) na više od sedamsto stranica, s preko stotinu likova, od kojih svaki govori različitim jezikom, narječjem i naglaskom, od uličnog slanga američkih marinaca, preko raznih arapskih varijanti, talijanskih regionalnih jezika i lokalnih narječja, pa sve do standardnog francuskog, latinskog i grčkog, autorica posvećuje punih deset godina. Ovaj, prema mišljenju mnogih kritičara (Aricò 1998, p. 194), najzreliji Fallacin rad, ${ }^{251}$ kojim se autorica kritici predstavlja kao već iskusna spisateljica u potpunosti posvećena umjetničkom stvaralaštvu, prati strukturu kompleksne ratne drame u tri čina, s mnoštvom likova čije se rasne, etničke i religijske različitosti neprestance prepliću. Ratne strahote Beiruta 1980., grada devetnaest različitih službenih vjerskih zajednica, grada najzelenijih vrtova i šuma, luksuznih aristokratskih art déco vila i čuvenih aleksandrijskih mozaika, grada jedne od najimpozantnijih luka Mediterana, kojom su prolazili najpoznatiji trgovci svijeta (Fallaci 1990, p. 41-43), opisane su unutar napetog i neizvjesnog tromjesečnog razdoblja, od trenutka atentata na američku i francusku vojnu bazu, do povlačenja međunarodnih trupa s prve linije bojišnice. Osobno svjedočeći još jednom zvjerskom razaranju beskrajne ljepote prirode i kulture, osjećajući dužnost i odgovornost da patnje jednog grada opiše i objasni, autorica, i ovaj put, unoseći sebe i vlastite ideološke stavove, kombinira stvarnost i fikciju, dokumentarističko i osobno:

Likovi ovoga romana izmišljeni su. Izmišljene su njihove priče, izmišljen je zaplet. Događaji koji su potakli zaplet istiniti su. Istinit je krajolik, istinit je rat u kojem priča nastaje. (p. 5)

\footnotetext{
${ }^{250}$ Paul William Roberts (1992) ističe kako je Fallacinom romanu Insciallah mjesto na samome vrhu, među djelima svjetske književnosti. Smatra ga jednim od čak deset najboljih ratnih romana ikad napisanih, razrađenijim i kvalitetnijim od Tolstojevog Rata i mira.

${ }^{251}$ Već unutar godine dana nakon prvog objavljivanja samo u Italiji djelo je prodano u preko 600000 primjeraka (Aricò 1998, p. 255).
} 
Nalazeći se u poziciji sada već iskusne ratne reporterke, ali i potvrđene spisateljice, Fallaci poput najsofisticiranije i najprodornije filmske leće, zumirajući izbliza, realistički opisuje i portretira sve ono što vidi i čuje, ali i ono što osjeća, ono što osjećaju vojnici čiji životi svakodnevno vise o koncu, tako da se više i ne sjećaju kakvog su okusa mir i sloboda. Oni su, primjećuje autorica, postali dio rata, dio bezizlaznog kaosa koji ne prestaje:

\begin{abstract}
Pravi vojnik sam sebe laže kada kaže da mrzi rat. On duboko voli rat. No, ne zato što je kakav divljak žedan ljudske krvi, već zato što voli tu vitalnost (koliko god ovo paradoksalno zvučalo) koju rat u sebi nosi. Vitalnost, izazov i misterij kojima se rat hrani [ ... ] Jer surova igra rata ulov je svih lova, izazov svih izazova, oklada svih oklada, lov na Čovjeka, izazivanje Smrti, oklada sa Životom [ ... ] I ako ne umre, ako u njem' ne ostavi dio svog tijela, vraćajući se kući osjećat će onu iscrpljujuću nostalgiju koja će ga pratiti do sljedeće postaje, a potom i do groba. (p. 115-116)
\end{abstract}

Ovaj kolosalni ratni triptih tragikomičnog karaktera, s mnoštvom likova sastavljenih po uzoru na Homerovu Ilijadu (p. 160-161), obiluje autobiografskim, autoreferencijalnim te metanarativnim elementima, unoseći u klasičnu ratnu poemu osjećaj fragmentiranosti i postmodernog.

U moru različitih šumova i glasova svakojakih jezika, u prvi plan dolaze dva neobično prodorna glasa: glas zavodljive libanonske udovice Ninette, te glas intradijegetskog pripovjedača, lika kojem autorica nadjenjuje ime Profesor. I dok nježan i ženstven glas putene tamnopute Libanonke koja tuguje za ubijenim suprugom i žudi za pažnjom talijanskog vojnika Angela (p. 109-111) asocira na Fallacino tugovanje i osjećaj praznine nakon Panagulisovog ubojstva, glas intradijegetskog pripovjedača, koji razbija klasičnu monolitnu narativnu strukturu, eksplicitno sebe prikazuje kao autoričnin alter ego.

Tri završne epistole, pisane u kurzivu na koncu svakoga čina, glas su imaginarnog pripovjedača koji se obraća svojoj, jednako imaginarnoj, voljenoj supruzi. ${ }^{252}$ Kako na koncu prvoga čina ekstradijegetski pripovjedač objašnjava, lik Profesora literarna je fatamorgana, trenutak preklapanja stvarnosti i fikcije, igra zrcala: „Više od lika, Profesor je bio igra zrcala, mise en abîme“ (p. 157). Ovaj intratekstualni zrcalni labirint dodatno se komplicira i fragmentira elementom psihičke krize, odnosno unutarnjeg konflikta i psihičke podvojenosti u kojem pripovjedač naglas raspravlja sa samim sobom, argumentirajući vlastite stavove o ratu,

\footnotetext{
${ }^{252}$,Ženi koju će voljeti, suputnici kojoj će slati sva ona pisma koja je sam sebi pisao kako bi zamislio i stvorio u svojim mislima roman koji upravo čitamo“ (Fallaci 1990, p. 320).
} 
o moralnim i etičkim pitanjima koje ratne strahote za sobom ostavljaju (p. 158), da bi ubrzo potom vrlo jasan i prodoran ženski glas, izvirući iz abisalnog metatekstualnog ponora, ushićeno objavio nastanak ,ove male moderne Ilijade s čašicom humora i svim onim herojima božanstvene grčke poeme“ (p. 160). Taj dvostruko metanarativan trenutak svojevrsna je oda žanru romana, trenutak divljenja svim onim mogućnostima koje roman, kao apsolutan i potpun žanrovski oblik, pruža. Zbog činjenice da je koncept kreativnog kaosa u njemu doveden do samoga vrhunca, zbog mogućnosti preklapanja stvarnosti i fikcije, roman je, ističe Profesor (p. 160), oblik koji ga je oduvijek najsnažnije privlačio. On je univerzalan prostor na granici sna i zbilje u kojem se svako ljudsko biće ima priliku prepoznati. No, da bi roman bio sveobuhvatan, da bi uspješno prikazao „ta čudna bića koja istovremeno plaču i smiju se“ (p. 160), objašnjava Profesor, autor romana mora posjedovati, do savršenstva istančati, dva temeljna osjećaja, ironiju i suosjećanje: „mora imati osmijeh na licu i suze u očima“ (p. 160).

Nakon ove metatekstualne intervencije, slijedi trenutak u kojem sam tekst $\mathrm{u}$ nastanku poprima tjelesne, gotovo fiziološke osobine. Pripovjedač (Fallaci) opisuje kako ga osjeća poput djeteta u utrobi, koje, iako još uvijek ne posjeduje jasne obrise, u sebi sadrži beskonačan broj mogućnosti. Njegovo srce već lupa, njegova pluća već dišu, njegovi noktići i kosa rastu (p. 321). Ovu taktilnu osjetilnu dimenziju odmah preuzima i ona fonična. Toplina i boja koje ljudski glas u sebi nosi dolazi sad do potpunog izražaja „imitirajući sav onaj intenzitet i svu onu esencijalnost koje vrelo života pruža“ (p. 322). I upravo zbog važnosti glasa, kazuje pripovjedač (p. 323.), tekstom se provlači heterogena vokalna polifonija, niz likova koji neprestance komuniciraju, viču i svađaju se, glasovno se preplićući na bezbroj raznih jezika i narječja, u beskonačno dugim dijalozima. I baš kao što je Flaubert govorio Madame-Bovary-c'est moi, tako tako i sama Fallaci, u ulozi pripovjedača priznaje:

\begin{abstract}
Ja sam svi oni, svi oni mnogi vlastiti, oni mnogi vlastiti koje nisam znala da posjedujem i sada sam ih otkrila [ ... ] Bit ću i jesam bilo koje od onih stvorenja koje moja mašta stvori, koje moj um začme, koje zahvaljujući mojim mislima i osjećajima postoje, koje se poput vampira mojom krvlju hrane. Naš je suživot toliko potpun da mi je nemoguće odvojiti se od njih. Kad oni plaču, plačem ja. Kad se oni smiju, smijem se ja. Kad se oni boje, bojim se ja. Kad oni umiru, umirem ja. I nikada se od njih ne odvajam. (p. 323)
\end{abstract}

Svi su ti likovi, objašnjava Profesor (p. 322), imaginarni obrisi vanjskoga svijeta, svijeta koji autorica osluškuje i promatra kako bi otela i preoblikovala stvarnost, pretočila je u prostor fikcije i svemogućeg. Kaotična i slojevita kreativna tekstualna strategija, kojom autorica 
pristupa izradi romana, otkrivena je tako upravo u ovome dijelu kao mukotrpan i dugotrajan proces neprekidnog revidiranja: „upornog brisanja i novog uspostavljanja stvarnosti“ (p. 322).

I druga epistola nastavlja se rasipanjem čitavog niza semiotičkih tragova, kojima se čitatelju osvjetljava ovo dugotrajno i kompleksno hermeneutičko putovanje. Opisani događaji zbivaju se u vremenskom periodu od ukupno tri mjeseca, a sve započinje invazijom stotine beirutskih divljih pasa $^{253}$ te dvostrukim atentatom na međunarodnu vojsku. No, nit vodilja, ove mnogostruke ratne priče, ističe Profesor (p. 321), sadržana je u jednoj, naoko jednostavnoj, a ipak izuzetno kompleksnoj jednadžbi austrijskog fizičara Ludwiga Boltzmana: ${ }^{254} \mathrm{~S}=\mathrm{K} \ln \mathrm{W}$, kojom jedan od glavnih likova biva u potpunosti opsjednut. Mladi talijanski vojnik Angelo, prema mišljenju nekih kritičara (Aricò 1998, p. 211) još jedan u nizu autoričinih alter ega, usprkos snažnom osjećaju beznađa koje vlada razorenim beirutskim ulicama, kao i potpunom kaosu i neprekidnom međusobnom sukobljavanju različitih etničkih skupina, trudi se pronaći jednadžbu kojom život i energija ljudske dobrote i poniznosti pobjeđuju put autodestrukcije i urođenog afiniteta prema boli i onozemaljskom.

Stvarajući kontingentan odnos realnog životnog iskustva i autobiografije, dokumentarističkog i fikcije, autorica izazovima historiografskog i literarnog priključuje i one osobne. Iako se u takvom žanrovskom bricolageu autor najčešće udaljava od sebe samog, postajući literarni $J a$ koji više nije, u slučaju Oriane Fallaci $J a$ kao da ponire i fizički se stapa s tekstom. Metanarativni labirint, pripovjedački solilokvij u drugom licu jednine, kojim Fallaci tjelesno, odnosno vokalno, povezuje s tekstualnim, na koncu posljednje epistole, te uoči epiloga, doživljava kulminaciju. Tjelesnom pojavom, obrisom lika novinarke iz Saigona, ${ }^{255}$ koja, gibajući se ovim tekstualnim prostorom „na glas izgovara riječi koje napisah“ (Fallaci 1990, p. 595), autorica u potpunosti razotkriva duboku intimnu povezanost i osjećaj bliskosti s vlastitim tekstom, odnosno proces pisanja kao proces vraćanja tijelu. I dok je u prvome pismu pripovjedač samo slutio da je fantazmogorička sjena saigonske novinarke povezana s tekstom u nastanku (p. 162), taj početni osjećaj nesigurnosti i strasti prema nepoznatom razbija se autoričnom karnalnom raprezentacijom pri kraju trećega pisma:

\footnotetext{
${ }^{253}$ Alegorija za palestinske militantske skupine.

254 Boltzmanova jednadžba, matematičkim jezikom, objašnjava nadmoć kaosa, entropije, u odnosu na rast prirodnog logaritma uređenosti i stabilnosti. Kaos i samouništenje, prema Boltzmanovoj jednadžbi, u ljudskoj su prirodi. Katastrofa je neizbježna, a smrt sigurna.

${ }^{255}$ Oriana Fallaci koju svijet tada prepoznaje kao novinarku koja je izravno pratila vijetnamska zbivanja.
} 
Nisam, dakle, griješio sumnjajući na Vas kao na svoj alter ego, rekao sam joj. No, sjena je odmakla glavom: Potpuno suprotno, Profesore, Vi ste bili alter ego. Moj alter ego [ ... ] Svatko od vas je moj alter ego, jedan aspekt ili jedan mogući aspekt mene same, jedan odraz u zrcalu kojim sam pokušala objasniti ljude [ ... ] jer riječi su tkivo našega tkiva, glagol koji postaje živo tkivo. (p. 596)

Simbolički prostor zrcala i jezičnih zakona, koji iziskuje određenu kontrolu vremena i događaja, vodio je autoricu u smjeru još uvijek nepoznatog. No, boreći se s falocentričnim lingvističkim poretkom, uranjajući u beskonačni proces jezične semioze, te konačno integrirajući u sebe moć Falusa, ona se sada „uzdiže poput orla“ (Cixous 1977b, p. 18) iznad vlastitog teksta, iznad prostora vremena i logosa, vraćajući sebe, svoje tijelo i svoj glas, tekstu.

Beirut 1983. u Fallacinom je romanu prikazan kao ruševni Babilonski toranj u kojem se sav onaj beskonačni kaos i višestruko preplitanje mnogobrojnih likova i događaja zrcale na razini lingvističke semioze, odnosno komparativne lingvistike. Translingvalna komunikacija i transkulturalna transpozicija u funkciji su isticanja umnožive heterogene različitosti jezika, kao i vremenske i prostorne otvorenosti njegovih semantičkih polja. ${ }^{256}$ Kontinuirano preklapanje međusobno različitih jezičnih skupina, narječja, dijalekata, sociolekata, stilova i registara, uz uvijek prisutnu komunikaciju koja svojim leksičkim, sintaktičkim te interpunkcijskim odabirom nalikuje u najvećoj mjeri govornom jeziku, ukazuje na autoričinu intenciju rušenja kulta monolitnog i stabilnog jezičnog sustava, ali i dovođenja u pitanje prvog, materinjeg, jezika, kao i razmatranja odnosa službenog nacionalnog standardnog jezika i onih neslužbenih jezičnih varijanti njemu, u patrijarhalnom sustavu mišljenja, hijerarhijski podređenim. Beirutsku „,ničiju zemlju“ ${ }^{257}$ egzotičan bliskoistočni prostor različitih kultura, vjera i jezika, autorica predstavlja kao nomadski prostor na međi heterogenih lingvističkih supstrata, koji, usprkos religijskoj i političkoj netrpeljivosti njegovih etničkih skupina, njeguje svojevrsnu lingvističku demokraciju:

\footnotetext{
${ }^{256}$ Derrida, J. (2007, p. 298-299).

${ }^{257}$ Lyotard, J. F. (1997, p. 116).
} 
Let us in, lasciateci entrare, let us in!

Get back, damit, get back. Indietro, maledizione, indietro.

[ ... ] Help me. Get me out, help me. Aiutatemi, tiratemi fuori, aiutatemi. (p. 22)

Ne me touchez pas, je veux mourir! Non toccatemi, voglio morire!

Mes jambes, le mie gambe! Où sont mes jambes, dove sono le mie gambe?!?

Aidez-moi, je vous en supplie! Aiutatemi, ve ne supplico!. (p. 30)

Mi vulevi vedè la guèra, ecu perché u minga dit che gu,

che ho la rotola bipartita al genöcc sinister.

$\mathrm{Al}$ ginocchio sinistro. Ben, l'u vista la guèra. $\mathrm{E}$ me pias no, non mi piace.

Me piasen no gli eserciti, me piasen no le uniformi. (p. 33).

Al- amerikin matu, jah! Gli americani morti, evviva!

Al-talieni bukra, jah! Gli italiani domani, viva!

Al-faransin matu, jah! I francesi morti, evviva! (p. 35)

Mors malorum finis est, la morte è la fine dei mali, dice Quintiliano.

[ ... ] Perfer et obdura, dolor hic tibi proderit olim.

Soffri e resisti, in futuro il tuo sforzo verrà ricompensato, ci insegna Ovidio. (pp. $58 ; 74)$

Parlez-vous français, faransîn?

Là, no, aamel maaruf, là..

Shubaddak, che voi?

[ ... ] Mish fahèm, non capisco.

Dam! Waladi biimut! Biimut, ambimut. (p. 68-69) 
U romanu Insciallah lingvističke granice pomiču one etničke. Dekonstrukcijom jezičnih, a time i kulturnih, granica, Fallaci dovodi u pitanje pojam identiteta i subjektiviteta. Raskidanjem ugovora s falogokratičnim lingvističkim autoritetima, odustajanjem od normi i konceptualne hijerarhijske organizacije jezičnih i kulturnih simbola, autorica uspostavlja čvrste veze s nomadskom estetikom, jednom od postmodernističkih interpretacija antropoloških, kulturnih i lingvističkih fenomena, u kojoj tradicija i teritorijalna stabilnost ustupljuju mjesto kulturnoj tranziciji i lingvističkoj deteritorijalizaciji (Braidotti, 2002). Unutar ruševina impozantnog multikulturnog i multietničkog grada, nomadskog prostora unutar kojeg različiti narodi ostavljaju svoj kulturni otisak, jezična heterogenost, kao i sve linije lingvističke tranzicije koje ona obuhvaća, ukazuju na sociolingvistički fenomen translingvalne komunikacije, na sposobnost i mogućnost različitih etničkih skupina da unutar kaotičnog plurilingvističkog prostora ostvare jasnu i konkretnu komunikaciju. Fallacino je djelo tako jasno usmjereno na negaciju jezičnog sustava kao transcendentalnog i povlašteno označenog sustava, kao prostora apsolutne i konačne fiksacije značenja, te se približava antitradicionalističkom i antiinstitucionalnom shvaćanju tekstualnog prostora kao onog $\mathrm{u}$ kojem svi lingvistički sustavi, sve sintagmatske i paradigmatske vrijednosti, poprimaju fluktuacijsko, pokretljivo svojstvo. U tom smislu, subjektu oduzeto pravo na jedino autentično tumačenje značenja vlastitog diskursa, vlastitog jezika, dano je čitatelju, odnosno sugovorniku. Jasna linearna destrukcija svih obrisa lingvističkog puritanizma pomiče tako roman u smjeru kulturnog i jezičnog relativizma, ${ }^{258}$ prihvaćanja jezika kao prostora neprekidne tranzicije i transgresije, prostora lingvističke deteritorijalizacije.

\footnotetext{
${ }^{258}$ Said, E. (1978).
} 


\section{Zaključak}

Čin pisanja čin je subjekta koji govori, te je uvijek preuvjetovan, odnosno pod dubokim je utjecajem ,nesvjesnih ideoloških privrženosti te nesvjesnih emocionalnih uloga i fantazija, baš kao i svjesnih motivacija“ (Moi 2007, p. 243). Psihoanalitička teorija, fenomenološka teorija subjektiviteta, te poststrukturalistička teorija teksta, zajedno s rodnim teorijama, razmatraju odnose spolnog, rodnog i tekstualnog, te suprotstavljajući se „romantičkim teorijama intencionalnosti““ (p. 242) nastoje razotkriti utjecaje i učinke tjelesnog i psihološkog na diskurzivno i performativno.

Za temeljitije i kvalitetnije razumijevanje recipročnih odnosa roda, spola i jezika, odnosno ženskog, ženstvenog i tekstualnog, te specifično ženskih i ženstvenih komunikacijskih strategija, nužno je bilo krenuti od ženske prirode i psihologije, stoga je u ovom radu ponuđeno psihoanalitičko shvaćanje ženskog subjekta, frojdovskim i lacanovskim rječnikom, ponuđen je koncept konstituiranja subjekta kao prvenstveno rodnog subjekta.

Žena je, dakle, spolno biće s karakterističnim anatomskim i fiziološkim spolnim obilježjima (Freud, 2006), koje, svaka na svoj način i u određenom životnom razdoblju, utječu na njezinu psihologiju, karakterne osobine, kognitivne vještine i percepciju, na njezinu osjetilnu i intuitivnu razinu, kao i komunikacijsku strategiju i kreativnost (Jung, 1977f). Ove konstatacije, međutim, nipošto ne predstavljaju put u bilo kakvu vrstu biološkog esencijalizma i determinizma ili, još gore, seksističke generalizacije. Priroda ženske tjelesnosti i seksualnosti čini ženu posebnom i različitom, no, to svakako ne znači da je bit ženskog i ženstvenog sažeta i reducirana na seksualnost.

Određene anatomske i psihofiziološke osobine i funkcije očito su determinirajuće za žensku i ženstvenu prirodu, poput, primjerice, različito strukturiranog nesvjesnog prostora, zbog čega žene posjeduju drugačije specifične erotsko-emotivne razine osobnosti, kao i različit udio primarnih emocija, poput intuicije i empatije (Jung 1977f, p. 225-226). Također, ženski odnos prema tipu objektnog izbora, različit od onog muškog, ostavlja ženu u položaju one koja „jest“, iako ne posjeduje (Freud, 1986; Lacan, 2017), čime ju čini sigurnijom u njezinom libidnom položaju (Freud 1986, p. 52), ne zahtijevajući, uvijek iznova, potvrdu one „druge strane“, dok njezin prirodno urođen narcizam (p. 56-57), kao i pomanjkanje kompaktnosti Nad-Ja strukture (Freud 2006, p. 415), obilježavaju ženu kao ranjiviji i nježniji spol. 
Sve ove psihološke osobine u velikoj mjeri određuju ženski subjektni položaj, njezin odnos prema stvarnosti, te način interpretacije i ekspresije emocija (p. 415). Ipak, na ženski su položaj i identitet utjecali i brojni evolucijski i sociokulturološki čimbenici. Podsvjesni i nesvjesni obrambeni psihički mehanizmi, poput procesa potiskivanja i sublimacije nagona, kojima su se žene kroz stoljeća zbog raznih političkih i društvenih ograničenja branile od uloge pasivnog i podređenog subjekta (Chodorow 1991, p. 246) u velikoj su mjeri utjecali na motivacijske i stvaralačke procese, kao i na prirodu ekspresije (Beauvoir, 2001). Dugostoljetna opresija patrijarhalnog sustava, nepovoljan odnos prema ženi u poslovnom i obiteljskom okruženju, rezultirao je i specifičnim, sociopolitički uvjetovanim, ženskim kreativnim strategijama (p. 33-34).

Žena jest, dakle, spoj prirode i kulture, nipošto inferiorna ili „druga“ (Beauvoir, 2016), no, ipak, posebna i različita (Kofman, 1985). Ženski subjekt, tjelesni je subjekt koji „govori, dakle jest“ (Kristeva 1980, p. 27), pripovijedajući o sebi, ali uvijek i o onom „drugom“ unutar sebe (Jung 1977f, p. 206-208; Irigaray 1977, p. 28). Žena, također, nije, kako zaključni rezultati ovog istraživanja pokazuju, jednostavan performativni učinak rodnih diskurza (Butler, 1990), jer ako ženu shvaćamo kao sinonim roda, tada vraćamo ženskost u binarni i bipolarni položaj homogenih monolitnih, falusno dominantnih, struktura, u kojima se sva ljepota i posebnost ženske i ženstvene heterogenosti, mnogostrukosti i varijabilnosti guše i nestaju.

Ženska i ženstvena percepcija i ekspresija stvarnosti odraz su, dakle, utjecaja prirode, ali i ženskog iskustva unutar društva. Imajući to na umu, te uzimajući u obzir sve one antropološke i povijesne okolnosti koje su ženu do vlastitog oslobođenja u konačnici i dovele, razvidno je da je za kvalitetan i sveobuhvatan pristup razumijevanju odnosa između ženskog, ženstvenog i tekstualnog, nužno uzeti u obzir sve kontekstualne i izvantekstualne okolnosti, sve biološke i psihološke aspekte, kao i povijesne i sociokulturološke utjecaje (Showalter, 1979).

Vraćajući se na jezik, kao medij putem kojeg se ustanovljuje subjekt, nazire se sljedeće pitanje: skriva li ženski tekst stvarnu ženu, odnosno njezine podsvjesne i nesvjesne psihološke mehanizme? Nakon niza istraživanja i analiza u području psiholingvistike i pragmalingvistike, ovim se radom u velikoj mjeri potvrđuje afirmativan odgovor. Naime, očito različita ženska kreativna tekstualna strategija, koja se sastoji od neprekidnih revidiranja, dekonstruiranja i rekonstruiranja (Gilbert i Gubar, 1979), različitog pristupa sintaksi i sintaktičkom ustroju 
(Cixous, 1975b, 1975c; Braidotti, 2002), kao i specifičnog, fragmentiranog i otvorenog narativnog pristupa tekstu (Cavarero, 1997), ukazuje na usku povezanost ženskog tijela, njezinih osobnih psiholoških mehanizama, kao i svih onih kolektivnih taloga (Jung, 1977b) oformljenih iskustvenim saznanjima unutar društva, s kreativnim tekstualnim prostorom.

Može li se, iz svega navedenog, zaključiti da postoji ženski jezik, ženski roman ili ženska rečenica? U velikoj mjeri, može. Ukoliko ženski jezik promatramo kao kognitivni fenomen u najužoj vezi s ženskim tijelom i ženskom seksualnošću (Irigaray, 1977; Cixous, 1975b), postaje gotovo neupitna njegova morfološka i fiziološka sličnost s tijelom iz kojeg je izniknuo. Vjerojatno je najuvjerljivija teza o bliskosti i sličnosti ženske morfologije i erotizma s ženskim načinom percepcije i ekspresije emocija, odnosno načinom verbalnog i pisanog izražavanja, ona Luce Irigaray, koja žensku morfofiziologiju analognom ženskoj retorici i tekstualnosti. Zbog mnogostrukog i nedjeljivog ženskog užitka, usko povezanog s anatomijom ženskih spolnih organa, ženski jezik postaje također raznolik, mnogostruk i nedjeljiv, postaje onaj koji ne isključuje, već spaja (1977, p. 24). Također, ženska intimna povezanost s vlastitim tijelom žensku će retoriku pretvoriti u taktilnu retoriku, fluidnih $i$ viskoznih svojstava (p. 109-110), podsjećajući istovremeno na ženstvenost kao na prirodno tekuće svojstvo kojeg obilježava utjecaj čitavog niza različitih fluida tijekom fertilnog razdoblja žene. U konačnici, kako i zaključuje Irigaray, upravo kao žensko tijelo i ženski će jezik, odnosno govor (le parler femme), biti definiran kao pluralan, inkluzivan i fluidan čin, kao izuzetno intiman, blisko s tjelesnim povezan, čin, koji će se, upravo poput fluida, uvijek opirati procesima konačne fiksacije značenja i označivanja, odnosno jasno izmicati patrijarhalnoj logici stabilnih, monolitnih i cjelovitih sustava znakova, sustava čvrsto ustanovljenih kanonskih formi (p. 141). U tom smislu, ženski će govor, u skladu s navedenim analogijama, često zvučati kao izuzetno izravan i spontan, nemiran i strastven čin, kojeg ne pokreću unaprijed pripremljeni kodovi i obrasci, već uska povezanost s materijalnim tijelom.

Ženski govor, govor kojim se žena uvijek iznova dodiruje, govor difuznih i mnogostrukih antiedipskih diskurzivnih metoda, stopit će se sa činom pisanja, pa će tako žensko pismo postati izravan i samoidentičan nastavak govornog čina (Cixous 1975c, p. 170), a ženstvenost u pisanju raspoznat će se kao davanje prednosti glasu (p. 172). Putem glasa, arhetipskog vokalnog otiska (Jung 1977b, p. 70; Cixous 1975c, p. 162), seksualno će prodirati u tekstualno, a žensko će pismo (l'écriture féminine) postati libidan čin kojim će autorica pisanje vraćati tijelu. 
Žensko pismo, spontan i otvoren sustav nesputanog strujanja i preplitanja koncepata, narativnih sekvenci i struktura (Cavarero, 1997), opirat će se tako jedinstvenom i cjelovitom sustavu falogokratične zapadnjačke tradicije. Prateći difuznost i fragmentiranost ženskog tijela i glasa, ženski će tekstovi postojati kao multifragmentiran slijed životnih segmenata (p. 101), rezistentni na svaku moguću sintezu i konačno oblikovanje (Battersby 1989, p. 151).

Na temelju svih navedenih zaključaka, pozivajući se na znanstveno relevantnu sekundarnu literaturu iz spomenutih interdisciplinarnih područja, ovim se radom došlo do konačne spoznaje o konkretnoj manifestaciji ženskog i ženstvenog u pojedinim tekstovima Oriane Fallaci. Analizom su se identificirali, a potom i dekonstruirali, svi oni retorički elementi, koji su, na bilo koji način, ukazivali na prisutnost specifičnog ženskog i ženstvenog jezika.

Dekonstrukcijom sintakse došlo se do saznanja o naglašenoj fuziji tjelesnog, kognitivnog i lingvističkog, pisanog i izgovorenog. Fallacina fluidna i viskozna sintaksa (Fallaci, 1975b) ritmičkim i tonalitetnim, prozodijskim i interpunkcijskim kombinacijama ukazala je na prožetost teksta, glasa i tijela, a njezin intiman i spontan, elegantan i transparentan stil, kao i erotogeno-heterogena biseksualna tekstualna strategija (Fallaci, 1962), potvrdila je prisutnost ženskog pisma. Morfofonetske intervencije, kojima je do osobitog izražaja došla autoričina fonična i taktilna retorika (Fallaci 1975b, p. 7), karakteristično ženska i ženstvena poetika (Irigaray, 1977, p. 76), čin pisanja pretvorile su u tjelesan čin, odnosno pismo u govor ženskog tijela, u materijalizaciju ženskosti, u retoriku libidne ženstvenosti.

Fallacine antiedipske diskurzivne metode, sudeći po autobiografskim podacima (De Stefano, 2015), u velikoj mjeri uvjetovane i njezinim osobnim iskustvima, ali i ženskim i Ženstvenim disidentskim decentraliziranim subjektnim položajem (Kristeva 1977b, p. 3-8), ukazale su na autoričin obrnut smjer kretanja u odnosu na falocentrične etablirane strukture kulturne i jezične moći. Odupirući se tradicionalnoj žanrovskoj klasifikaciji, njegujući nejasne i otvorene kombinacije stilova, žanrova i registara, javnog i osobnog, subjektivnog i objektivnog, pisanog i izgovorenog, tekstualnog i izvantekstualnog, autorica je potvrdila svoju žensku i ženstvenu subverzivnu perspektivu, govoreći glasom „drugog“ o sebi (Fallaci, 1974), odnosno vlastitim glasom o onom „drugom“ unutar sebe (Fallaci, 1975b), izmičući uvijek konačnoj fiksaciji i označivanju. 
Orijentalistička percepcija stvarnosti, transkulturalnih i transjezičnih granica (Fallaci, 1990), Fallaci je konstantno vraćala u položaj marginalnog, heterogenog i različitog, u položaj nomadskog subjekta, ženskog tranzicijskog i fluktuirajućeg subjekta u neprekidnom procesu jezične i kulturološke metamorfoze (Braidotti 2002, p. 13). Njezino jasno suprotstavljanje apsolutnim jezičnim i političkim definicijama (Fallaci, 1979b), zatvorenim sustavima i patrijarhalnim kanonskim vrijednostima, približilo je pismo nomadskim procesima jezične dekonstrukcije i deteritorijalizacije (p. 29-32), ostavljajući kao trajne posljedice multidisciplinarnost, mnogostrukost i varijabilnost, zamjenjujući simbolički prostor monolitnog, cjelovitog i stabilnog jezičnog sustava imaginarnim, ženskim i ženstvenim, prostorom heterogenog kaosa i fragmentiranosti.

Zaključak cjelokupnog istraživanja odnosi se, dakle, na potvrdu bliskog, sinkroniziranog i recipročnog odnosa rodnog, spolnog i jezičnog, odnosno ženskog, ženstvenog i tekstualnog, te na jasnije definiranje ženskog govora i seksualiziranog ženskog pisma, u kontekstu psihoanalitičkih i rodnih teorija, kognitivne lingvistike i pragmalingvistike, s osobitim naglaskom na neosporiv i jednako važan utjecaj kako biologije i fiziologije, tako i društva i kulture.

Također, zaključak se temelji i na praktičnoj analizi Fallacinih tekstova, koji ostavljaju snažan dojam ženskog i ženstvenog glasa, odnosno retorike slobodnoga govornog čina, kojom se seksualno pretvara u tekstualno, govor u pismo, te dokazima o fuziji tijela (ženskog), govora (ženstvenog) i pisma (tekstualnog). 


\section{Bibliografija}

I. Izbor priručnika, znanstvenih i stručnih radova teorijske literature:

AA.VV. (2002) Hrvatska enciklopedija. Zagreb: Leksikografski Zavod Miroslav Krleža.

Andrews, K. (1980) »Panagoulis Dead and Alive« u: Greece in the Dark. Amsterdam: Hakkert.

Arendt, H. (1987) La vita della mente. (prev. na tal. Zanetti, G.) Bologna: Il Mulino, str. 162.

Aricò, S. (1986) Breaking the Ice: An In-Depth Look at Oriana Fallaci's Interview Technique. Journalism Quarterly, 63 (3) str. 587-93.

---- (1998) Oriana Fallaci. The Woman and the Myth. Carbondale/Edwardsville: Sothern Illinois University Press.

Bachofen, J.J. (1988) Il matriarcato. Storia e mito tra Oriente e Occidente. (prev. na tal. Jesi F.; Schiavoni G. Der Mythos vom Matriarchat) Torino: Einaudi.

Bahtin, M. (1980) Marksizam i filozofija jezika. (1929) prev. Matijašević, R. Beograd: Nolit.

Barthes, R. (1953) Le Degré zéro de l'écriture. Paris: Seuil. Korišten prijevod: Writing Degree Zero and Elements of Semiology. (1984) prev. s franc. Lavers, A.; Smith, C. London: Jonathan Cape.

---- (1977) »The Death of the Author« (1967) u: Heath, S. (ur.) Image Music Text. London: Fontana.

Battersby, Ch. (1989) Gender and Genius. London: The Women's Press.

(1998) The Phenomenal Woman. Feminist Metaphysics and the Patterns of Identity. Cambridge: Polity Press, str. 1-4; 7.

Beaujour, M. (1980) Miroirs d'encre. Rhétorique de l'autoportrait. Paris: Seuil. 
de Beauvoir, S. (2016) Drugi spol. (Le Deuxième Sexe, 1949.), prev. Šimat, M., ur. Tomašević N., Zagreb: Naklada Ljevak.

----- (2001) La donna e la creatività. Milano: Mimesis Eterotopia.

Blixen, K. (1959) La mia Africa. Milano: Feltrinelli.

Bonfante, J. (1975) An Interview Is a Love Story. Time, 20. listopad, str. 72.

Bourdieu, P. (1993) The Field of Cultural Production. Cambridge: Polity Press.

Braidotti, R. (1994) Dissonanze. Le donne e la filosofia contemporanea. Milano: La Tartaruga, str. 280.

---- (2002) Nuovi soggetti nomadi. Crispino, A. M. (ur.) Roma: Luca Sosella.

Brown, N. (1989) Život protiv smrti. Zagreb: Naprijed.

Butler, J. (1996) Corpi che contano. I limiti discorsivi del „, sesso “. Milano: Feltrinelli.

---- (2000) Nevolje s rodom. Feminizam i subverzija identiteta. (Gender Trouble. Feminism and the Subversion of Identity. 1990., prev. s eng. Paić-Jurinić, M., ur. Radman V.) Zagreb: Ženska Infoteka.

Carey, J. (1992) The Intellectuals and the Masses: Pride and Pregudice among the literary Intelligentia, 1880-1939. London: Faber and Faber.

Carrano, P. (1978) »Oriana Fallaci« u: Le signore grandi firme. Rimini/Florence: Guaraldi, str. 69-102.

Cavarero, A. (1987) »Per una teoria della differenza sessuale« u: AA.VV. Diotima. Il pensiero della differenza sessuale. Milano: La Tartaruga, str. 52-55; 78.

---- (1990a) Nonostante Platone. Figure femminili nella filosofia antica. Roma: Editori Riuniti.

(1990b) »Dire la nascita « u: AA.VV. Diotima. Mettere al mondo il mondo. Milano: La Tartaruga, str. 93-121.

---- (1997) Tu che mi guardi, tu che mi racconti. Milano: Feltrinelli. 
---- (2009) »Il pensiero femminista. Un approccio teoretico« u: Cavarero, A.; Restaino, F. Le filosofie feministe. Milano: Bruno Mondadori.

--- (2014) Inclinazioni. Critica della retitudine. Milano: Raffaello Cortina.

Cecchi, U. (2013) Oriana Fallaci. Cercami dov'é il dolore. 1. izd. Firenze: Mauro Pagliai.

Ceserani, R. (1986) »Come insegnare letteratura« u: Cecchi, O; Ghidetti, E. (1986) Fare storia della letteratura, Roma: Riuniti, str.151.

Chodorow, N.J. (1978) The Reproducing of Mothering. Psychoanalysis and the Sociology of Gender. Berkeley: University of California Press.

---- (1991) »Freud on women« u: Jerome, N. (ur.), The Cambridge Companion to Freud. Cambridge: Cambridge University Press, str. 224-248.

Cixous, H. (1975a) »Sorties« u: Kramarić, Z. (ur.) (1998) Književnost, povijest i politika. prev. s franc. Krajina K., Osijek: Svjetla grada, str. 258-266.

(1975b) Le Rire de la Méduse. L'Arc, (61) str. 39-54. prev. Cohen, K.; Cohen P., 1976. The laugh of the Medusa. Signs, 1, ljeto, 975-899. Citirano iz pretiska u: Marks, E.; Courtivron, I., de (ur.) 1980. New French Feminisms. Brighton: Harvester, str. 245-264.

---- (1975c) La Jeune Née. Clément, C. (ur.) Paris: UGE, 10/18.

---- (1977a) Entretien avec Françoise van Rossum-Guyon. Revue des sciences humaines, 168, listopad-prosinac, str. 479-493.

---- (1977b) La Venue à l'écriture. (s Leclerc, A.; Gagnon, M.) Paris: UGE, 10/18.

(1981) Castration or decapitation. Signs, 7 (1), str. 41-55.

Collin, F. (1986) Pensare/Raccontare. Hannah Arendt. „,DWF 3“, str. 37.

Corsini, G. (1974) L'istituzione letteraria. Napoli: Liguori.

Čačinovič, N. (2000) U ženskom ključu. Ogledi u teoriji kulture. Zagreb: Centar za ženske studije.

Davis, D.A. (2008) »Freud, Jung, and psychoanalysis« u: Young-Eisendrath, P.; Dawson, T. (ur.) The Cambridge Companion to Jung. Cambridge: Cambridge University Press. 
Delleuze G.; Guattari F. (1986) Nomadology: The War Machine. New York: Semiotexte.

Derrida, J. (1986) Mémoires: for Paul de Man. The Wellek Library Lectures at the University of California. Irvine/New York: Columbia University Press.

(1988) The Ear of the Other. Otobiography, Transference, Translation. (prev. na eng. Kamuf, P.) Lincoln/Nebraska: University of Nebraska Press.

---- (2007) Pisanje i razlika (L'écriture et la différance, 1967.) prev. s franc. Mikšić, V., Sarajevo/Zagreb: Šahinpašić (Biblioteka Diskursi).

Dinnerstein, D. (1999) The Mermaid and the Minotaur: Sexual Arrangements and Human Malaise. New York: Other Press.

Doederlein, S.W. (1982) Comment on Jehlen. Signs, 8 (1), str. 164-166.

Dolbier, M. (1966) Not a novel, not an essay, but a new kind of writing. World Journal Tribune, 26. Oct.

Durić, D. (2013) Uvod u psihoanalizu - od edipske do narcističke kulture. Zagreb: Leykam international.

Eagleton, T. (1987) Književna teorija. Zagreb: Sveučilišna naklada Liber, str. 165-207.

Ellmann, M. (1968) Thinking About Women. New York: Harcourt.

Emerson, G. (1980) Oriana Fallaci: Divine Troublemaker. Vogue, Nov., str. 334.

Ferretti, G. C. (1988) La fortuna letteraria. Milano: Transeuropea.

Finci, P. (2011) Osobno kao tekst. Goldstein, S. (ur.) Zagreb: Antibarbarus.

Firestone, Sh. (2003) The Dialectic of Sex: The Case for Feminist Revolution. (1970) New York/Farrar: Straus and Giroux.

Foucault, M. (1994) »L'écriture de soi« u: Dits et écrits. (1954-1988) IV tom, Paris: Gallimard.

Franks, L. (1981) Behind the Fallaci Image. Saturday Review, siječanj, str. 19. 
Frattaroli, E. (2008) »Me and my anima: through the dark glass of the Jungian/Freudian interface « u: Young-Eisendrath, P.; Dawson, T. (ur.) The Cambridge Companion to Jung. Cambridge: Cambridge University Press.

Freud, S. (1955)»The Uncanny« u: Collected Works of Sigmund Freud. (1919) Vol. 17. London: Hogarth Press, str. 217-252.

----- (1978a) »O nekim psihičkim posljedicama anatomske razlike među spolovima« (Einige psychische Folgen des Anatomischen Geschlechtsuntersschieds, 1925) u: Studienausgabe, Bd. V, Frankfurt: S. Fischer Verlag, str. 253-266.

---- (1978b) »Razrješenje Edipovog kompleksa« (Der Untergang des Ödipuskomplexes, 1924) u: Studienausgabe, Bd. V, Frankfurt: S. Fischer Verlag, str. 243-252.

---- (1978c) »Nelagoda u kulturi« (Das Unbehangen in der Kultur, 1929) u: Studienausgabe, Bd. IX, Frankfurt: S. Fischer Verlag, str. 191-270.

(1986) »Prilog uvodu u narcizam« (1914) u: Budućnost jedne iluzije. Flego, G. (ur.) Zagreb: Naprijed, str. 71-94.

---- (2000) »Totem i tabu, neke podudarnosti u duševnom životu divljaka i neurotičara« (Totem und Tabu, Einige Übereinstimmungen im Seelenleben der Wilden und der Neurotiker, 1918) Zagreb: Stari grad.

---- (2001a) »O ženskoj seksualnosti« (1931) u: Kruh i ruže. br. 14, str. 11-18.

---- (2001b) Tumačenje snova (Die Traumdeutung über den Traum, 1899) Zagreb: Stari grad. (2006) XXXII predavanje »Ženskost« Nova predavanja za uvođenje u psihoanalizu. u: Kompletan uvod u psihoanalizu. Novi Sad: Nova Knjiga.

Friedan, B. (1963) The Feminine Mystique. New York: Dell.

Fromm, E. (1977) Čovjek za sebe. Zagreb: Naprijed, str. 13-14.

Gallino, T.G. (1989) »Le Grandi Madri: un'introduzione al mito e all'archetipo« u: Le Grandi Madri. Milano: Feltrinelli, str.8.

Gatt-Rutter, J. (1996) Oriana Fallaci: the Retoric of Freedom. Oxford: Berg Publishers. 
Genette, G. (1980) Narative Discourse. (prev. s franc. Levin, J.,E., Figures III, 1972, Paris: Seuil) Oxford: Basil Blackwell.

---- (1987) Seuils. Paris: Seuil.

(1991) Fiction et diction. Paris: Seuil.

Gilbert, S.M.; Gubar, S. (1979) The Madwoman in The Attic: The Women Writer and the Nineteenth Century Literary Imagination. New Haven: Yale University Press.

Greimas, A.J. (1969) Sémantique structurale: recherche de méthode. Paris: Librairie Larousse.

Guarini, R. (1979) Come si fabbrica un romanzo di staggione, Il Messaggero, 24. lipanj.

Gunn J.V. (1982) Autobiography. Toward a Poetics of Experience. Philadelphia: University of Pennsylvania Press, str.30.

Gusdorf, G. (1991) Auto-bio-graphie. Lignes de vie 2. Paris: Odile Jacob.

Haraway, D. (1995) Un manifesto per cyborg, Donne, tecnologie e biopolitiche del corpo. Milano: Feltrinelli, str. 40-42.

Homer, S. (2005) Jacques Lacan. London: Routledge Critical Thinkers.

Irigaray, L. (1974) Spéculum de l'autre femme. Paris: Minuit.

---- (1977) Ce sexe qui n'en est pas un. Paris: Minuit.

---- (1989) Sessi e genealogie. (prev. na tal. Muraro, L.) Milano: La Tartaruga, str. 151.

---- (1990) Je, Tu, Nous. Pour une culture de la différence. Paris: Éditions Grasset \& Fasquelle.

Jakobson, R. (1987) Language in Literature. Pomorska, K.; Rudy, S. (ur.) Cambridge/London: Harvard University Press.

Jehlen, M. (1981) Archimedes and the paradox of feminist criticism. Signs, 6 (4), str. 575601. 
Johnson, B. (1986) Apostrophe, animation and abortion. Diacritics, 16 (1), str. 29-39, Warhol i Herndl (1991) str. 630.

Jung, C.G. (1977a) »Teorija erosa« u: O psihologiji nesvjesnog, odabrana djela C.G.Junga, knjiga druga (Gesammelte Werke, Walter- Verlag AG, Olten, 1971.) Jerotić V.; Vlajković S. (ur.) prev. Pavle Milekić, Beograd: Matica srpska.

----- (1977b) »Lično i nadlično ili kolektivno nesvjesno« u: O psihologiji nesvjesnog, odabrana djela C.G.Junga, knjiga druga (Gesammelte Werke, Walter- Verlag AG, Olten, 1971.) Jerotić V.; Vlajković S. (ur.) prev. Pavle Milekić, Beograd: Matica srpska.

---- (1977c) »Lično i kolektivno nesvjesno« u: O psihologiji nesvjesnog, odabrana djela C.G.Junga, knjiga druga (Gesammelte Werke, Walter- Verlag AG, Olten, 1971.) Jerotić V.; Vlajković S. (ur.) prev. Pavle Milekić, Beograd: Matica srpska.

---- (1977d) »Funkcija nesvjesnog« u: O psihologiji nesvjesnog, odabrana djela C.G.Junga, knjiga druga (Gesammelte Werke, Walter- Verlag AG, Olten, 1971.) Jerotić V.; Vlajković S. (ur.) prev. Pavle Milekić, Beograd: Matica srpska.

---- (1977f) »Anima i Animus« u: O psihologiji nesvjesnog, odabrana djela C.G.Junga, knjiga druga (Gesammelte Werke, Walter- Verlag AG, Olten, 1971.) Jerotić V.; Vlajković S. (ur.) prev. Pavle Milekić, Beograd: Matica srpska.

----- (2005) Preobražaji i simboli libida. (Wandlungen und Symbole der Libido, 1912), Beograd: Atos.

(2008) »Brak kao psihološki odnos« u: Razvoju ličnosti. (Über die Entwicklung der Persönlichkeit; Das Ehe-Buch, eine neue Sinngebung in Zusammenklang der Stimmen führender Zeitgenossen, 1925.) prev. Milakara, B.; Milakara, A., 3. izd., Beograd: Akademska knjiga.

Klein, M. (1983) »Prilog psihogenezi manično-depresivnih stanja« u: Zavist i Zahvalnost. Zagreb: Naprijed.

Kofman, S. (1985) The Enigma of Woman: Woman in Freud's writings. prev. s franc. Porter, C. (l'Enigme de la Femme: La Femme dans les textes de Freud. Editions Galilée, 1980.) Ithaca/London: Cornell University Press. 
Kolodny, A. (1975) Some notes on defining a feminist literary criticism. Critical Inquiry, 2 (1), str. 75-92. Pretiskano u: Brown, C. L.; Olson, K. (ur.) (1978) Feminist Criticism: Essays on Theory. Poetry and Prose. Metuchen: Scarecrow Press, str. 37-58.

---- (1980) »Dancing through the minefield: some observations on the theory, practice and politics of a feminist literary criticism« u: Feminist Studies. 6 (1), str. 1-25.

Kristeva, J. (1974a) La Révolution du langage poétique. Paris: Seuil.

(1974b) La femme, ce n'est jamais ça. Tel Quel, 59, jesen, str. 19-24.

---- (1977a) A partir de Polylogue. (Intervju s Françoise van Rossum-Guyon.) Revue des sciences humaines, 168, prosinac, str. 495-501.

---- (1977b) Un nouveau type d'intellectuel: le dissident. Tel Quel,74, zima, str. 3-8.

---- (1980) »The ethics of linguistics« u: Kristeva, J. Desire in Language: A Semiotic Approach to Literature. Oxford: Blackwell, str. 23-35.

(1981) Žensko Vreme. (prev. iz Moi, T. 1986. Women's Time. Oxford: Basil Blackwell) Feministička gledišta i gledišta o feminizmu. Gledišta. Časopis za društvenu kritiku i teoriju, siječanj-travanj 1990. 1 (2), str. 17-38.

Kurlansky, M. (2007) 1968. godina koja je uzdrmala svijet. Vujičić, K. (ur.) prev. Biličić, D. Zagreb: Naklada Ljevak.

Lacan, J. (1983a) »Značenje falusa« (Die Bedeutung des Phallus) u: Spisi. (1966. Écrits. Paris: Éditions du Seuil) Beograd: Prosveta.

---- (1983b) »Stadijum ogledala kao tvoritelj funkcije Ja kakva nam se otkriva u psihoanalitičkom iskustvu« u: Spisi. (1966. Écrits. Paris: Éditions du Seuil) Beograd: Prosveta.

----- (1992) «Desire and the Interpretation of Desire in Hamlet» u: Literature and Pyscoanalysis - The Question of Reading: Otherwise. Felman, Sh. (ur.) Baltimore/London: Johns Hopkins University Press.

(2017) Formations of the unconscious : the seminar of Jacques Lacan. Book V. Miller, J. A. (ur.) prev. Grigg, R., Cambridge: Polity Press. 
Laplanche, J.; Pontalis, J.B. (2010) Enciclopedia della psicoanalisi. Roma/Bari: Laterza.

Laurentis de, T. (1999) Soggetti eccentrici. Milano: Feltrinelli, str. 104-106.

Lepschy, G. (1991) »Language and Sexism« u: Baránski i Vinall, str. 117.

---- (1989) Nuovi saggi di linguistica italiana. Bologna: Il mulino.

Lukšić, I. (ur.) (2000) Šezdesete. Zagreb: Biblioteka književna smotra, Hrvatsko filološko društvo.

Lyotard, J.F. (1997) Postmodern Fables. (prev. Abeele, Van Den G.) Minneapolis: University of Minnesota Press

de Man, P. (1984) »Autobiography as De-Facement « u: The Rhetoric of Romanticism. New York: Columbia University Press.

Marabini, C. (1979) Panagulis, amore mio. La Nazione, 28. lipanj.

Marcuse, H. (1965) Eros i civilizacija. Naprijed: Zagreb.

---- (1977) »Poraz nove levice« u: Marksizam u svetu. str. 1-2.

----- (1989) Čovjek jedne dimenzije. Sarajevo: Veselin Masleša.

Matijašević, Ž. (2006) Strukturiranje nesvjesnog: Freud i Lacan. Zagreb: AGM.

(2011) Uvod u psihoanalizu: Edip, Hamlet, Jekyll/Hyde. Zagreb: Leykam international.

McLuhan, M. (1992) The Global Village. New York: Oxford University Press.

Millett, K. (1969) Sexual Politics. London: Virago.

Milani, M. (1971) »La lingua effimera di Oriana Fallaci« u: la Battana. VIII.25, svibanj, Rijeka, str. 23-49.

Mitchell, J. (1974) Psychoanalysis and Feminism. Harmondsworth: Penguin.

Moi, T. (2007) Seksualna/tekstualna politika. prev. Grdešić M., Zagreb: AGM.

Ostellino, P. (1990) Oriana Fallaci: è l'ora di Insciallah. Supplemento del Corriere della Sera. 
Petchesky, R.P. (1980) Reproductive Freedom: Beyond A Woman's Right to Choose. Signs. Journal of Woman in Culture and Society, 5 (4), str. 661.

Porzio, D. (1965) A Cape Kennedy il sole non muore. Oggi, br. 43.

Poirier, R. (1971) The Performing Self. New York: Oxford University Press.

Putanec, V. (2000) Dictionnaire Francais-Croate. Zagreb: Školska knjiga.

Rabaté, J. M. (2001) Jacques Lacan and the Subject of Literature. New York: Palgrave.

Rasy, E. (1984) Le donne e la letteratura. Roma: Editori Riuniti.

Reale, G. et al. (2000) Platone. Tutti gli scritti. Milano: Bompiani.

Recalcati, M. (2012) Jacques Lacan. Desiderio, godimento e soggettivazione. Milano: Raffaello Cortina Editore.

Restaino, F. (2002) »Il pensiero femminista. Una storia possibile« u: Le filosofie feministe. Milano: Bruno Mondadori.

Rivera-Garretas, M.M. (1998) Nominare il mondo al femminile. Roma: Editori Riuniti.

Roberts, P.W. (1992) Fallaci's Masterpiece: A Modern Day Illiad. Toronto Star, 12. Dec.

Rosa, G. (1982) »Il nome di Oriana« u: Spinazzola, V. Produzione letteraria e mercato culturale. Milano: Milano Libri Edizioni.

Rossi, G.; Degiarde, E.; Verlicchi, L. (1977) Obiettivo Donna. Milano: Cooperativa Edizioni Jaca Book.

Roszak, T. (1978) Kontrakultura: razmatranja o tehnokratskom društvu i njegovoj mladenačkoj opoziciji. Zagreb: Naprijed.

Rubin, G.S. (1975) »The Traffic in Women: Notes on the 'Political Economy' of Sex« u: Reiter, R. (ur.) Toward an Anthropology of Women. New York: Monthly Review Press.

Said, E. (1978) Orientalism. New York: Pantheon Books.

Samuels, A. (2008) »The Jung problem«u: Young-Eisendrath, P.; Dawson, T. (ur.) The Cambridge Companion to Jung. Cambridge: Cambridge University Press. 
Sanford, D. (1975) The Lady of the Tapes. Esquire, lipanj, str. 102.

Santini, A. (1990a) Scrive con il sangue e dice cretino ai cretini. Oggi, 25. srpnja, str. 50.

---- (1990b) In Messico Oriana ebbe il suo battesimo del fuoco. Oggi, 8. kolovoza, str. 38-42.

de Saussure, F. (2003) Corso di linguistica genereale. (Cours de linguistique général, Ch. Bailly i A. Séchehaye (ur.), Payot, 1916), Bari: Laterza.

Showalter, E. (1979) »Towards a feminist poetics« u: Jacobus, M. (ur.) Women Writing and Writing About Woman. London: Croom Helm, str. 22-41.

---- (1981) Feminist criticism in the wilderness. Critical Inquiry, 8 (1), Chicago: University of Chicago Press, str. 179-205.

Sissa, G. (1983) »Il corpo della donna. Lineamenti di una ginecologia filosofica« u: Campese, S.; Manuli, P.; Sissa, G., Madre Materia. Torino: Boringhieri, str. 81-145.

Snell, D. (1966) A Florentine girl and the spaceman. Life, br. 122, listopad-studeni.

Spinazzola, V. (1979) Così si seduce un pubblico di massa. L'Unità, 6. prosinac.

---- (1990) L'offerta letteraria: narratori italiani del secondo novecento. Milano: Morano Editore.

Stanley, L. (1992) The Autobiographical I. Manchester/New York: Manchester University Press.

De Stefano, Cr. (2014) Oriana. Una donna. Milano: Rizzoli.

Steiner, G. (1994) Dopo Babele: aspetti del linguaggio e della ttraduzione. Milano: Garzanti.

Teodori, M. (1978) Historijat novih ljevica u Europi (1956-1978) (Storia delle Nuove Sinistre in Europa 1956-1978, 1976. Bologna: Il Mulino) prev. Domiter T.; Šentija J., Zagreb: Oour Globus.

Todorov, Tz. (1972) Einführung in die Fantastische Literatur. München: Hanser.

Violi, P. (1986) L'infinito singolare. Considerazioni sulle differenze sessuali nel linguaggio. Napoli: Essedue. 
Winnicott, D. (2004) Igra i stvarnost. Zagreb: Prosvjeta.

Wittig, M. The Point of View: Universal or Particular. Femminist Issues, 3 (2), jesen 1983, str. 64.

----- The Trojan Horse. Femminist Issues, 4 (2), jesen 1984., str. 68.

Wolfe, T.; Johnson, E.W. (1973) The New Journalism. With an Anthology. New York: Harper-Row.

Woolf, V. (1958) The Three Guineas. London: Penguin.

---- (2003) Le donne e la scrittura. (Woman and Writing, 1979) Milano: La Tartaruga.

---- (2004) A Room of One's Own. (1929) London: Penguin Group.

Young-Eisendrath, P. (2004) Subject to Change: Jung, Gender, and Subjectivity in Psychoanalysis. London: Routledge. 


\section{Izbor iz bibliografije Oriane Fallaci}

Fallaci, O. (1956) Ho vissuto in Ungheria l'ultima notte di libertà. Europeo, br. 46, 11. studenog, str. 30-33.

----- (1961) Il sesso inutile. Milano: Rizzoli.

----- (1962) Penelope alla guerra. Milano: Rizzoli.

----- (1963) Gli antipatici. Milano: Rizzoli.

---- (1965a) L'ultimo cow-boy. Europeo, br. 48, 28. studenog, str. 76-84.

----- (1965b) Se il sole muore. Milano: Rizzoli.

---- (1968a) Le storie di Saigon. Europeo, br. 5, 1. veljače.

---- (1968b) Sono tornata a Saigon in fiamme. Europeo, br. 8, 22. veljače.

---- (1968c) La notte di sangue in cui sono stata ferita. Europeo, 17. listopada, br. 24, str. 2447.

----- (1968d) Città del Messico sconvolta da sei ore di violenta battaglia. Corriere Mercantile, 4. listopada, str. 1.

----- (1968e) Diario dal Messico. Europeo, 24. listopada, br. 43, str. 29-35.

----- (1969a) Conrad. Europeo, 20. studenog, br. 47, str. 38-48.

----- (1969b) La più grande avventura del secolo. Europeo, 10. srpnja, br. 28, str. 44-51).

---- (1969c) I nostri inviati sulla luna. Europeo, 17. srpnja, br. 29, str. 42-58.

----- (1969d) Il giorno dopo. Europeo, 24. srpnja, br. 30, str. 43-56.

----- (1969e) Niente e così sia. Milano: Rizzoli.

----- (1970a) Tra i guerriglieri arabi. Europeo, 26. veljače, br. 9, str. 34-45.

----- (1970b) L'intervista con Arafat. L'uomo che è a capo dei guerriglieri arabi. Europeo, br. 11, 12. ožujka, str. 23-29. 
----- (1970c) Quel giorno sulla luna. Milano: Rizzoli.

----- (1972) Bhutto risponde a Indira Gandhi. Europeo, br. 17, 27. travnja, str. 52-60.

----- (1973) Lo scia di Persia. Europeo, br. 44, 1. studenog, str. 82-91.

----- (1974) Intervista con la storia. Milano: Rizzoli.

---- (1975a) Lettera a Kissinger dopo il suo fallimento. Europeo, br. 14, 13. travnja, str. 3233.

(1975b) Lettera a un bambino mai nato. Milano: Rizzoli.

----- (1979a) An Interview with Khomeini. New York Time Magazine, 7. listopada.

----- (1979b) Un Uomo. Milano: Rizzoli.

---- (1982) Oriana Fallaci intervista il Generale Sharon. Europeo, br. 36, 6. rujna, str. 6-21.

----- (1988) Io e Gheddafi. E gli porsi il cappio perché si impiccasse da solo. Corriere della Sera, 24. travanj.

----- (1990) Insciallah. Milano: Rizzoli. 


\section{Biografija}

Astrid Kovačević rođena je 28.12.1980. godine u Rijeci. Osnovnu školu i opću gimnaziju završila je na Malom Lošinju. Diplomirala je talijanski jezik i književnost pri Odsjeku za talijanski jezik i književnost Filozofskog fakulteta u Puli, te komparativnu književnost na Filozofskom fakultetu u Zagrebu, Summa Cum Laude. Dobitnica je nagrade Ministarstva znanosti, obrazovanja i sporta za izvrsnost, te je boravila na nekoliko stručnih usavršavanja u inozemstvu. Njezini su temeljni znanstveni interesi psihoanalitička i poststrukturalistička teorija teksta, kognitivna lingvistika i pragmalingvistika. Radi u nastavi i bavi se prevođenjem. 